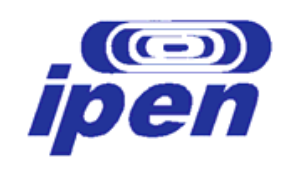

INSTITUTO DE PESQUISAS ENERGÉTICAS E NUCLEARES

Autarquia associada à Universidade de São Paulo

\title{
ESTUDO DE UM CASCO NACIONAL E SUA INSTALAÇÃO PARA ARMAZENAGEM SECA DE COMBUSTÍVEL NUCLEAR QUEIMADO GERADO EM REATORES PWR
}

LUIZ SERGIO ROMANATO

Tese apresentada como parte dos requisitos para obtenção do Grau de Doutor em Ciências na Área de Tecnologia Nuclear - Aplicações

Orientadora:

Profa. Dra. BARBARA M. RZYSKI

São Paulo 


\section{Dedico}

À minha esposa Mônica e ao meu filho Allan, por tudo o que representam para mim. 


\section{AGRADECIMENTOS}

Agradeço,

Ao Instituto de Pesquisas Energéticas e Nucleares, IPEN, pela oportunidade de poder desenvolver meu trabalho de doutorado.

Ao Centro Tecnológico da Marinha em São Paulo (CTMSP), pelo incentivo na realização do doutorado.

Ao Centro de Desenvolvimento de Tecnologia Nuclear (CDTN), pela oportunidade de participação em testes em protótipos de cascos para combustível nuclear.

À Profa. Dra. Barbara Maria Rzyski, pela valiosa orientação, ensinamentos, incentivo e amizade em todos os momentos necessários desde a época da realização do mestrado, sem o que não seria possível realizar este trabalho.

Aos meus pais, Walter e Leonite, que proporcionaram os primeiros passos rumo ao saber e ao estudo.

À minha esposa Mônica e ao meu filho Allan, pela compreensão e apoio neste período. 
Se um homem tem um talento e não tem capacidade de usá-lo, ele fracassou. Se ele tem um talento e usa somente a metade deste, ele fracassou parcialmente. Se ele tem um talento e de certa forma aprende a usá-lo em sua totalidade, ele triunfou gloriosamente $e$ obteve uma satisfação e um triunfo que poucos homens conhecerão. 


\section{ESTUDO DE UM CASCO NACIONAL E SUA INSTALAÇÃO PARA ARMAZENAGEM SECA DE COMBUSTÍVEL NUCLEAR QUEIMADO GERADO EM REATORES PWR}

\section{LUIZ SERGIO ROMANATO}

\section{RESUMO}

O combustível nuclear queimado (CNQ) é retirado do reator nuclear após exaurir sua eficiência de geração de energia. Após ser retirado do reator, esse combustível é temporariamente armazenado em piscinas com água na própria instalação do reator. Durante esse tempo, o calor gerado e os elementos radioativos presentes, de meia-vida média e curta, caem até níveis que permitem retirar o combustível queimado da piscina e enviá-lo para depósitos temporários de via seca. Nessa fase, o material precisa ser armazenado segura e eficazmente de forma que possa ser recuperado em futuro próximo, ou disposto como rejeito radioativo. A quantidade de combustível queimado cresce anualmente e, nos próximos anos, vai aumentar mais ainda por causa da construção de novas instalações de geração de energia de origem nuclear. Nos dias de hoje, o número de instalações novas voltou a atingir os níveis da década de 1970, porque é maior que a quantidade de ações de descomissionamento de instalações antigas. Antes que seja tomada qualquer decisão, seja a de recuperar o combustível remanescente ou considerar o CNQ como rejeito radioativo, o mesmo precisa ser isolado em um dos diferentes tipos de armazenagem existentes no mundo. No presente estudo mostra-se que a armazenagem do CNQ, via seca, em cascos é a opção mais vantajosa. Propõe-se um modelo de casco autóctone para combustível de reatores de potência e de uma instalação de armazenagem para abrigar esses cascos. É um estudo multidisciplinar no qual foi desenvolvida a parte conceitual de engenharia e que poderá ser usada para que o CNQ nacional, retirado dos reatores brasileiros de potência, seja armazenado com segurança por um longo período até que as autoridades brasileiras decidam o local para deposição final.

Palavras Chave: Combustível nuclear queimado. Cascos de armazenagem. Armazenagem de combustível nuclear queimado. 


\title{
STUDY OF A BRAZILIAN CASK AND ITS INSTALLATION FOR PWR SPENT NUCLEAR FUEL DRY STORAGE
}

\section{LUIZ SERGIO ROMANATO}

\begin{abstract}
Spent nuclear fuel (SNF) is removed from the nuclear reactor after the depletion on efficiency in generating energy. After the withdrawal from the reactor core, the SNF is temporarily stored in pools at the same site of the reactor. At this time, the generated heat and the short and medium lived radioactive elements decay to levels that allow removing SNF from the pool and sending it to temporary dry storage. In that phase, the fuel needs to be safely and efficiently stored, and then, it can be retrieved in a future, or can be disposed as radioactive waste. The amount of spent fuel increases annually and, in the next years, will still increase more, because of the construction of new nuclear plants. Today, the number of new facilities back up to levels of the 1970's, since it is greater than the amount of decommissioning in old installations. As no final decision on the back-end of the nuclear fuel cycle is foreseen in the near future in Brazil, either to recover the SNF or to consider it as radioactive waste, this material has to be isolated in some type of storage model existing around the world. In the present study it is shown that dry SNF storage is the best option. A national cask model for SNF as well these casks storage installation are proposed. It is a multidisciplinary study in which the engineering conceptual task was developed and may be applied to national SNF removed from the Brazilian power reactors, to be safely stored for a long time until the Brazilian authorities will decide about the site for final disposal.
\end{abstract}


“ESTUDO DE UM CASCO NACIONAL E SUA INSTALAÇ̃̃O PARA ARMAZENAGEM SECA DE COMBUSTÍVEL NUCLEAR QUEIMADO GERADO EM REATORES PWR"

\section{SUMÁRIO}

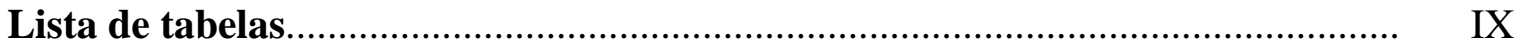

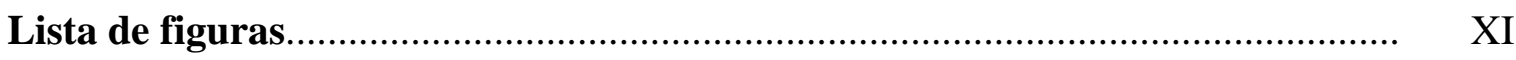

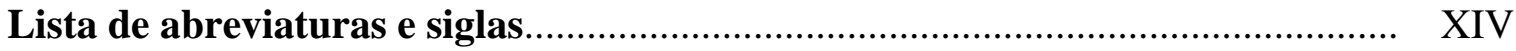

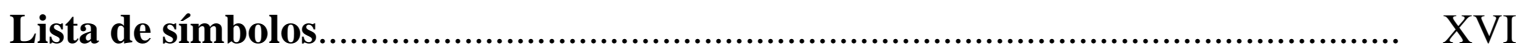

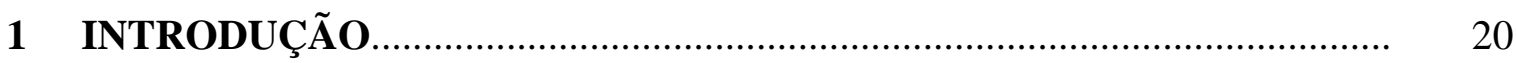

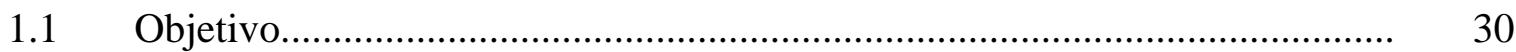

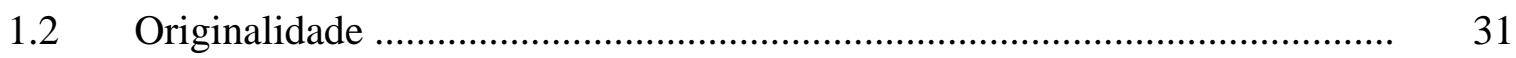

2 REVISÃO DA LITERATURA …............................................................ 33

3 CASCOS, ARMAZENAGEM E TRANSPORTE .......................................... 60

3.1 Caracterização do combustível nuclear ............................................................ 60

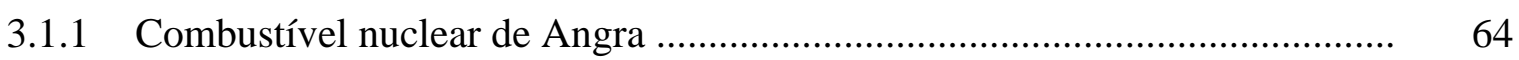

3.2 Estudo do casco para armazenagem ........................................................... 65

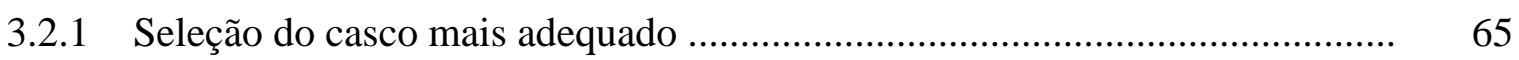

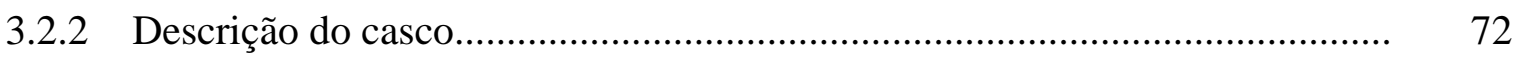

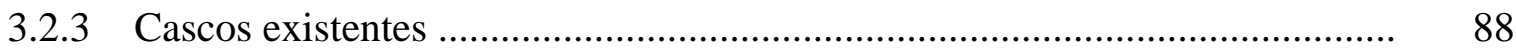

3.2.4 Previsões para armazenagem de CNQ do futuro tipo de reator EPR.............. 98

3.2.5 Ensaios físicos dos cascos...................................................................... 98

3.2.6 Identificação e rastreabilidade dos cascos contendo CNQ ............................ 100

3.3 Instalações de armazenagem seca............................................................ 101

3.3.1 Instalações de armazenagem provisória de CNQ existentes no mundo ......... 101

3.3.2 Segurança de uma instalação de armazenagem de CNQ .............................. 112

3.3.3 Vantagens da armazenagem seca em relação à úmida .................................. 115

3.3.4 Comparação dos custos de instalação de armazenagem de CNQ ................... 117

3.4 Regulamentação para o desenvolvimento de cascos para CNQ..................... 117

3.5 Transporte de cascos com CNQ............................................................ 119

4 PROPOSTA DE CASCO E INSTALAÇÃO DE ARMAZENAGEM NACIONAIS PARA CNQ-PWR.................................................................................... 126

4.1 Proposta de casco nacional de armazenagem de CNQ................................... 126

4.1.1 Seleção da quantidade de elementos CNQ para o casco proposto ................. 130

4.1.2 Nível de radiação com vistas ao transporte e armazenagem seca de CNQPWR.

4.1.3 Interação da radiação com os materiais utilizados para a construção do casco

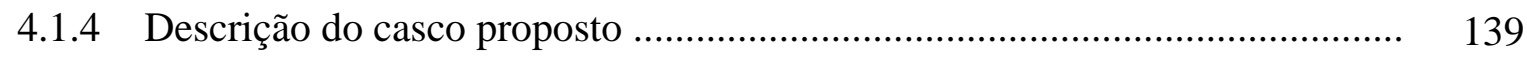

4.1.5 Processo de qualificação do casco ........................................................... 141

4.1.6 Ensaios físicos..................................................................................... 145

4.1.7 Análise de risco do casco......................................................................... 151

4.1.8 Fabricação do casco............................................................................... 152 
4.1.9 Custo do casco.

4.1.10 Liberação do casco para transporte e armazenagem.

4.2 Proposta de uma instalação nacional de armazenagem seca provisória de CNQ em cascos.

4.2.1 Localização

4.2.2 Proposta de instalação de armazenagem seca de CNQ no Brasil....

4.2.3 Processos de licenciamento de uma instalação de armazenagem seca de CNQ no Brasil.

4.2.4 Custo de uma instalação de armazenagem seca

4.3 Transporte de cascos com CNQ................................................................. 168

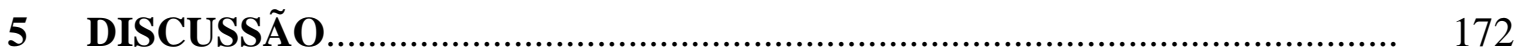

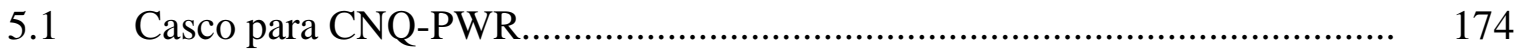

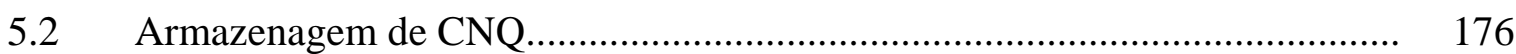

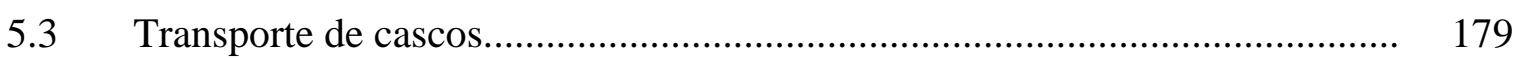

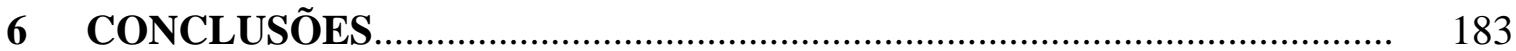

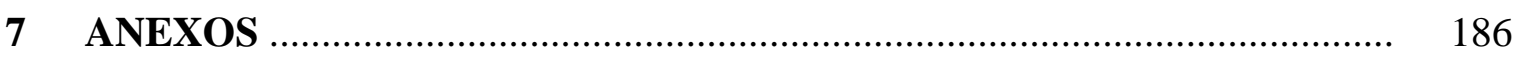

ANEXO A - Tabelas de calor de decaimento do CNQ................................. 187

ANEXO B - Normas alemãs para projeto do casco metálico........................ 190

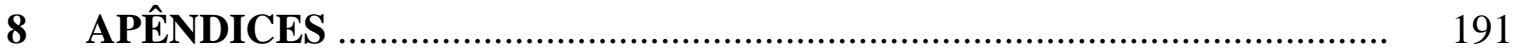

APÊNDICE A - Ajuste das curvas das espessuras........................................ 192

APÊNDICE B - Áreas, volumes e massas.................................................. 195

APÊNDICE C - Utilização do AHP para tomada de decisão quanto à escolha da quantidade de elementos CNQ no casco...................................... 198

APÊNDICE D - Corte longitudinal do casco............................................. 208

APÊNDICE E - Vista explodida dos componentes principais do casco....... 209

APÊNDICE F - Detalhe da tampa do dreno................................................. 210

APÊNDICE G - Corte do casco de armazenagem........................................ 211

APÊNDICE H - Detalhe da válvula de inserção de gás inerte...................... 212

APÊNDICE I - Detalhes das células de armazenagem do cesto.................... 213

APÊNDICE J - Planta baixa instalação de armazenagem (primeiro módulo) 214

APÊNDICE K - Corte frontal da instalação de armazenagem (primeiro módulo).

APÊNDICE L - Corte lateral esquerdo da instalação de armazenagem (primeiro módulo)

APÊNDICE M - Corte lateral direito da instalação de armazenagem (primeiro módulo).

APÊNDICE N - Planta baixa da instalação de armazenagem completa........ 218

9 REFERÊNCIAS BIBLIOGRÁFICAS 


\section{LISTA DE TABELAS}

Tabela 1 Atividade relativa do CNQ em função do tempo decorrido após a retirada do núcleo do reator.

Tabela 2 Características dos elementos combustíveis de Angra 1 e 2

Tabela 3 Potência térmica do CNQ-PWR com burnup máximo de 33 GWd/tU, após o desligamento do reator para descarga na piscina

Tabela 4 Cascos NUHOMS ${ }^{\circledR}$ apenas para armazenagem e para transporte e armazenagem

Tabela 5 Cascos NUHOMS ${ }^{\circledR}$ de transferência

Tabela 6 Comparação entre alguns cascos de armazenagem provisória para CNQ PWR

Tabela 7 Instalações de armazenagem provisória seca para CNQ PWR .

Tabela 8 Vantagens e desvantagens nas armazenagens de CNQ

Tabela 9 Custos relativos de uma instalação de armazenagem seca.....

Tabela 10 Espessura de blindagem para CNQ - PWR, burnup de 33 GWd/tU, dois anos de resfriamento.

Tabela 11 Espessura de blindagem para CNQ - PWR, burnup de $33 \mathrm{GWd} / \mathrm{tU}$, três anos de resfriamento.

Tabela 12 Espessura de blindagem para CNQ- PWR, burnup de $33 \mathrm{GWd} / \mathrm{tU}$, cinco anos de resfriamento

Tabela 13 Espessura de blindagem para CNQ - PWR, burnup de $33 \mathrm{GWd} / \mathrm{tU}$, sete anos de resfriamento.

Tabela 14 Espessura de blindagem para CNQ - PWR, burnup de 33 GWd/tU, dez anos de resfriamento.

Tabela 15 Espessura da blindagem contra raios gama e nêutrons após resfriamento do CNQ-PWR, com burnup de $33 \mathrm{GWd} / \mathrm{tU}$, por cinco anos em piscina.

Tabela 16 Espessuras dos revestimentos interno, intermediário e externo, para confecção dos cascos para CNQ-PWR, com burnup de $33 \mathrm{GWd} / \mathrm{tU}$..

Tabela 17 Valores dos diâmetros da cavidade do casco para CNQ-PWR, com burnup de 33GWd/tU

Tabela 18 Densidades dos materiais candidatos para a confecção dos cascos para CNQ-PWR

Tabela 19 Massa dos cascos para CNQ- PWR, com burnup de $33 \mathrm{GWd} / \mathrm{tU}$ e cinco ano de resfriamento.

Tabela 20 Diâmetro externo e altura dos cascos para CNQ- PWR, com burnup de $33 \mathrm{GWd} / \mathrm{tU}$ e cinco anos de resfriamento.

Tabela 21 Relação massa do combustível/massa total do casco para CNQPWR, com burnup de $33 \mathrm{GWd} / \mathrm{tU}$ e cinco anos de resfriamento. 
Tabela 22 Comparativo dimensional entre cascos de chumbo, ferro e urânio para 21 elementos CNQ- PWR, com burnup de $33 \mathrm{GWd} / \mathrm{tU}$ e cinco anos de resfriamento.

Tabela 23 Tópicos para a localização de instalações nucleares............................. 155

Tabela 24 Resumo das técnicas de monitoração em armazenagem seca, práticas correntes e futuras, aplicadas em alguns países..... 


\section{LISTA DE FIGURAS}

Figura 1 Roteiro conceitual da armazenagem provisória de CNQ ...................... 20

Figura 2 Seqüência de retirada do CNQ e armazenagem em casco..................... 22

Figura 3 Desenho do casco GNS-16 utilizado pelo IPEN, em 1999, para transportar CNQ de origem americana do Brasil para os EUA.............

Figura 4 Casco GNS-16 utilizado pelo IPEN, em 1999, para transportar CNQ de origem americana do Brasil para os EUA.......................................... 25

Figura 5 Exemplo de seção de um casco com dispersão cerâmica ...................... 28

Figura 6 Rendimento de fissão do ${ }^{235} \mathrm{U}$ e ${ }^{238} \mathrm{U}$ em função do número de massa . 61

Figura 7 Curva de decaimento de rejeitos de atividade alta ................................ 62

Figura 8 Calor de decaimento do CNQ …....................................................... 63

Figura 9 Corte do elemento combustível de reator PWR com as varetas, elemento de controle, tubos guia e grade espaçadora............................ 65

Figura 10 Efeito no $k_{\text {eff }}$ em relação à densidade de boro na superfície do cesto.... 67

Figura 11 Propósitos funcionais dos cascos quanto ao sistema de transferência e transporte

Figura 12 Casco de armazenagem de CNQ …..................................................... 72

Figura 13 Casco para armazenagem seca de CNQ tipo CANDU (Canadá) acomodado na posição horizontal em casco na posição vertical........... 73

Figura 14 Casco com CNQ na posição vertical (A) e horizontal(B).................... 73

Figura 15 Corte de um casco metálico de armazenagem de CNQ ....................... 74

Figura 16 Corte transversal um casco metálico de armazenagem de CNQ ......... 75

Figura 17 Cesto usado em um casco para armazenagem de CNQ-PWR............... 75

Figura 18 Cesto interno de um casco de armazenagem de CNQ, tipo 'embalagem de ovos'.......................................................................... 76

Figura 19 Detalhe de uma célula de armazenagem ............................................ 77

Figura 20 Detalhe da tampa de um casco metálico de armazenagem .................. 78

Figura 21 Detalhe do munhão superior de um casco metálico de armazenagem... 79

Figura 22 Detalhe do munhão inferior de um casco metálico de armazenagem.... 79

Figura 23 Detalhe do fundo de um casco metálico de armazenagem de CNQ.... 80

Figura 24 Casco metálico para transporte, armazenagem e deslocamento na instalação de CNQ-PWR, tipo TN24 da Transnucleàire

Figura 25 Protótipo de casco após queda de $9 \mathrm{~m}$................................................. 82

Figura 26 Detalhe do absorvedor de impacto após impacto resultante da queda de $9 \mathrm{~m}$

Figura 27 Corte de um casco de concreto para armazenagem de CNQ 
Figura 28 Casco de concreto para armazenagem de CNQ .................................. 84

Figura 29 Corte de um casco CONSTOR ${ }^{\circledR}$ para acondicionamento de CNQ, transporte e armazenagem

Figura 30 Taxas de exposição na superfície de um casco para CNQ com relação à espessura da parede

Figura 31 Fixação do acoplamento de elevação no casco com CNQ 87

Figura 32 Sistema acoplado aos ganchos para elevação de um casco para CNQ . 87

Figura 33 Corte do sistema de armazenagem $\mathrm{Hi}$-Storm 90

Figura 34 Casco de armazenagem UMS, da NAC, para CNQ-PWR 91

Figura 35 Cesto para o casco UMS de concreto da NAC para CNQ-PWR. 92

Figura 36 Armazenagem de cascos NUHOMS ${ }^{\circledR}$ na horizontal 95

Figura 37 Diferentes modelos de cascos do tipo TN24 para armazenagem seca na vertical acima do nível do solo, produzidos pela Transnucléaire ....

Figura 38 Exemplo de armazenagem seca para CNQ em poços em: (A) Idaho, EUA, refrigerada a ar, (B) Wylfa, Inglaterra, semelhante a da Hungria pela mesma companhia BNS Nuclear Services, (C) Hanford, EUA.....

Figura 39 Exemplo de planta arquitetônica de uma instalação de armazenagem seca de CNQ em cascos, sugerida pelo Japão.

Figura 40 Interior da instalação de Gorleben, na qual podem ser vistos os cascos de armazenagem de CNQ.

Figura 41 Cascos metálicos de armazenagem de CNQ - Gorleben, Alemanha ... 105

Figura 42 Planta da instalação de CNQ de Trillo, Espanha ................................... 106

Figura 43 Corte lateral da Instalação de CNQ de Trillo, Espanha ....................... 106

Figura 44 Localização de 16 instalações de armazenagem provisória de CNQPWR no território dos EUA.

Figura 45 Instalação de armazenagem temporária de Surry - EUA .................... 108

Figura 46 Instalação de armazenagem temporária de Palisades - EUA .............. 108

Figura 47 Instalação de Calvert Cliffs - EUA de armazenagem seca temporária de cascos na posição horizontal............................................................ 109

Figura 48 Instalação de ZWILAG, Suíça, para armazenagem seca de CNQ ........ 110

Figura 49 Cascos de aço com CNQ armazenados dentro da instalação ZWILAG, Suíça

Figura 50 Transporte do casco de concreto com CNQ, Zaporizhzhya, Ucrânia ...

Figura 51 Localização da zona de armazenagem seca de CNQ em Zaporizhzhya

Figura 52 Esquema de abrigo para cascos de CNQ para melhor proteção física..

Figura 53 Conceito dos limites regulamentares na concepção de um casco para armazenagem de CNQ

Figura 54 Exemplo de casco de transporte ferroviário de CNQ-PWR 
Figura 55 Fluxograma do transporte de cascos com CNQ.................................. 121

Figura 56 Transporte rodoviário de casco metálico de CNQ................................ 122

Figura 57 Corte de um casco de CNQ utilizado em transporte ferroviário............ 122

Figura 58 Corte de um navio usado no transporte de CNQ................................. 123

Figura 59 Esquema de disposição dos cilindros concêntricos componentes de um casco para CNQ-PWR..

Figura 60 Dimensões básicas de um casco para CNQ-PWR................................. 132

Figura 61 Arranjos geométricos da distribuição dos elementos CNQ-PWR (1, 4, 8 e 12 elementos)

Figura 62 Arranjos geométricos da distribuição dos elementos CNQ-PWR (15 e 18 elementos)

Figura 63 Arranjos geométricos da distribuição dos elementos CNQ-PWR (16, 21, 24 e 32 elementos)..

Figura 64 Configuração dos 21 elementos CNQ-PWR no cesto a ser inserido no casco sugerido na presente tese

Figura 65 Casco de armazenagem para 21 elementos CNQ-PWR

Figura 66 Montagem alternativa ao teste de estanqueidade de protótipo de casco para CNQ

Figura 67 Teste de queda de 1,2m de altura, de protótipo de casco para CNQ.....

Figura 68 Teste de queda de barra de uma altura de $1 \mathrm{~m}$ sobre o protótipo de casco para CNQ

Figura 69 Teste de queda de 1m de altura de protótipo de casco para CNQ sobre uma barra pontiaguda

Figura 70 Teste de queda de $9 \mathrm{~m}$ de altura de protótipo de casco para CNQ ........ 150

Figura 71 Sugestão de esquema de fabricação de um casco metálico para CNQ ao longo de um ano

Figura 72 Proposta de planta da instalação de armazenagem de CNQ-PWR e dimensões principais

Figura 73 Exemplo de veículo de movimentação de casco com CNQ .nas instalações de armazenagem

Figura 74 Desenho esquemático da proposta de veículo para a movimentação de cascos, com CNQ-PWR dentro da instalação de armazenagem seca ...

Figura 75 Vista aérea de uma simulação de instalação de armazenagem de CNQ - PWR de Angra 1, 2 e simulação de Angra 3, localizado no próprio terreno da Central Nuclear de Angra 
LISTA DE ABREVIATURAS E SIGLAS

$\begin{array}{ll}\text { ABNT } & \text { Associação Brasileira de Normas Técnicas } \\ \text { AECL } & \text { Atomic Energy of Canada Limited } \\ \text { AFR } & \text { Away from reactor storage (Armazenagem longe do reator) } \\ \text { AHP } & \text { Analytical Hierarchy Process (Processo Hierárquico Analítico) } \\ \text { ALARA } & \text { As Low As Reasonable Achievable } \\ \text { AOI } & \text { Autorização para Operação Inicial } \\ \text { AOP } & \text { Autorização para Operação Permanente } \\ \text { APR } & \text { Avaliação Probabilística do Risco } \\ \text { ASME } & \text { American Society of Mechanical Engineers } \\ \text { BNG } & \text { British Nuclear Group } \\ \text { BWR } & \text { Boiling Water Reactor }\end{array}$

CANDU Canadian Deuterium Uranium

CASTOR Cask of Storage for Radioactive Materials

CDTN Centro de Desenvolvimento de Tecnologia Nuclear

CNEN Comissão Nacional de Energia Nuclear

CNQ Combustível Nuclear Queimado

CONSTOR Concrete Storage Cask

CRIEPI Central Research Institute of Electric Power Industry

CTMSP Centro Tecnológico da Marinha em São Paulo

DU Depleted Uranium (Urânio empobrecido)

EIA Estudo de Impacto Ambiental

EPR European Pessurized Reactor

GNB Gesellshaft für Nuklear Behälter

GNS General Nuclear Systems

HI Holtec International

IAEA International Atomic Energy Agency

IEA Instituto de Energia Atômica

INMM Institute of Nuclear Material Management

IPEN Instituto de Pesquisas Energéticas e Nucleares

ISFSI Independent Spent Fuel Storage Installation

ISO International Standard Organization 
LI Licença de Instalação

LO Licença de Operação

LP Licença Prévia

MACSTOR Casco de concreto desenvolvido pelo AECL (Canadá)

MPC Muti Purpose Canister

MTR Material Test Reactor

MTU Metric ton of Uranium (tonelada métrica de urânio)

NAC Nuclear Assurance Corporation

NBR Norma Brasileira

NPP Nuclear Power Plant (Instalação nuclear)

NSNFP National Spent Nuclear Fuel Program

NUHOMS Nuclear Horizontal Modular System

ORNL Oak Ridge National Laboratory

ONRR Office of NuclearRegulatory Research

PF Produtos de fissão

PWR Pressurized Water Reactor

RBMK Reator russo refrigerado à água e moderado por grafite

RFAS Relatório Final de Análise de Segurança

RIMA Relatório de Impacto no Meio Ambiente

RPAS Relatório Preliminar de Análise de Segurança

SKB Svensk Kärnbränslehantering AB (Empresa de energia nuclear sueca)

STC Spent fuel Transport Cask

THM Ton of Heavy Metal (tonelada de metal pesado)

UMC Universal MPC System

USNRC United States Nuclear Regulatory Commission

VVER Reator de potência russo refrigerado à água e moderado à água

ZWILAG Zwischenlager Würenlingen AG (Instalação de armazenagem suíça) 


\section{LISTA DE SÍMBOLOS}

a

${ }^{\circ} \mathrm{C}$

bar

Ba

cm

Ci

Cd

Cs

d

D

$\mathbf{D}_{\mathbf{g}}$

D Final

$\mathbf{D}_{\text {I }}$

D Inter

$\mathbf{D}_{\mathbf{n}}$

$\mathbf{e}_{1}$

$\mathbf{e}_{2}$

$\mathbf{e}_{3}$

$\mathbf{e}_{4}$

$\mathbf{e}_{5}$

Eu

Fe

$\mathrm{g} / \mathrm{cm}^{3}$

$\mathbf{G W d} / \mathbf{t U}$ gigawatt dia por tonelada de urânio

GWe

h

$\mathbf{h}_{\mathbf{g}}$

$\mathbf{h}_{\mathbf{c e}}$

$\mathbf{h}_{\mathrm{CI}}$

$\mathbf{h}_{\text {Cinter }}$

$\mathbf{h}_{\mathrm{Cn}}$

$\mathbf{h}_{\text {Final }}$

anos

grau Celsius ambiente

bário

centímetro $\left(\mathrm{m} \times 10^{-2}\right)$

Curie

cádmio

césio

densidade

diâmetro da cavidade do cesto

diâmetro do cilindro de contenção de gama

diâmetro do cilindro interno

diâmetro do cilindro intermediário

espessura do revestimento interno

espessura da contenção de gama

espessura do revestimento intermediário

espessura da contenção de nêutrons

espessura do revestimento externo

európio

ferro

grama por centímetro cúbico

gigawatt elétrico

altura do elemento CNQ

altura do cilindro de contenção de gama

altura do cesto

altura do cilindro interno

altura do cilindro intermediário

altura do cilindro de contenção de neutrons

altura do cilindro externo (altura do casco)

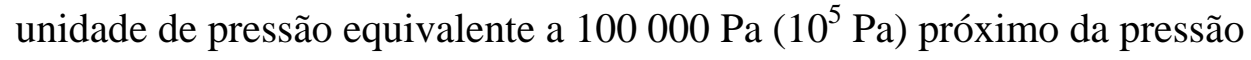

diâmetro do cilindro externo (diâmetro do casco)

diâmetro do cilindro de contenção de neutrons 


\begin{tabular}{|c|c|}
\hline I & iodo \\
\hline $\mathbf{k}_{\text {eff }}$ & fator de multiplicação efetivo (criticalidade) \\
\hline kg & quilograma $\left(\mathrm{g} \times 10^{3}\right)$ \\
\hline $\mathrm{kgf} / \mathrm{cm}^{2}$ & quilograma força por centímetro quadrado \\
\hline $\mathbf{k m} / \mathbf{h}$ & quilometro por hora \\
\hline kPa & quilopascal \\
\hline $\mathbf{k W}$ & quilowatt $\left(\mathrm{W} \times 10^{3}\right)$ \\
\hline $\mathbf{K r}$ & criptônio \\
\hline $\mathbf{L}$ & litro \\
\hline $\mathbf{m}$ & metro \\
\hline $\mathbf{m}_{\mathbf{c e}}$ & massa dos cestos \\
\hline $\mathbf{m}_{\mathrm{CNQ}}$ & massa do combustível nuclear queimado \\
\hline $\mathbf{m S v} / \mathbf{h}$ & milisievert por hora \\
\hline MeV & megaeletronvolt \\
\hline MJ & megajoule $\left(\mathrm{J} \times 10^{6}\right)$ \\
\hline MW & megawatt $\left(\mathrm{W} \times 10^{6}\right)$ \\
\hline MW(e) & megawatt elétrico \\
\hline $\mathbf{P b}$ & chumbo \\
\hline Pd & paládio \\
\hline $\mathbf{P u}$ & plutônio \\
\hline Se & selênio \\
\hline Sm & samário \\
\hline Sn & estanho \\
\hline Sr & estrôncio \\
\hline tHM & tonelada de metal pesado \\
\hline ton & tonelada \\
\hline $\mathbf{T}_{\mathbf{1} / \mathbf{2}}$ & meia vida \\
\hline Tc & tecnécio \\
\hline $\mathbf{U}$ & urânio \\
\hline $\mathbf{U O}_{2}$ & dióxido de urânio \\
\hline Vg & volume do cilindro de contenção gama \\
\hline $\mathbf{V}_{\text {ce }}$ & volume do cesto \\
\hline $\mathbf{V}_{\text {Ext }}$ & volume do revestimento externo \\
\hline
\end{tabular}




$\begin{array}{ll}\mathbf{V}_{\mathbf{I}} & \text { volume do cilindro de revestimento interno } \\ \mathbf{V}_{\text {Inter }} & \text { volume do cilindro de revestimento intermediário } \\ \mathbf{V}_{\mathbf{n}} & \text { volume do cilindro de contenção de neutrons } \\ \mathbf{Y} & \text { ítrio } \\ \mathbf{Z r} & \text { zircônio } \\ \boldsymbol{\alpha} & \text { partícula alfa } \\ \beta & \text { partícula beta } \\ \gamma & \text { raios gama }\end{array}$


1 INTRODUÇÃO 


\section{INTRODUÇÃO}

Quando o combustível nuclear, que não consegue sustentar uma reação nuclear em cadeia de forma eficiente, é removido do reator, é denominado “combustível irradiado” ou “combustível nuclear queimado (CNQ)” (Bunn et al., 2001). Entre 1/4 e 1/3 do total do combustível de um reator é substituído por combustível novo a cada 12 a 18 meses (USNRC, 2008). Esse combustível, geralmente, é armazenado em piscinas no mesmo prédio do reator, próximo ao núcleo ou em instalações anexas. Com o passar do tempo, após a retirada do núcleo do reator, a atividade do CNQ diminui e este segue a rota estabelecida pelo programa nuclear de cada país - reprocessamento ou deposição definitiva como rejeito radioativo. Na Figura 1 é apresentado um roteiro conceitual da armazenagem provisória e gerência de CNQ (Romanato; Rzyski, 2006).

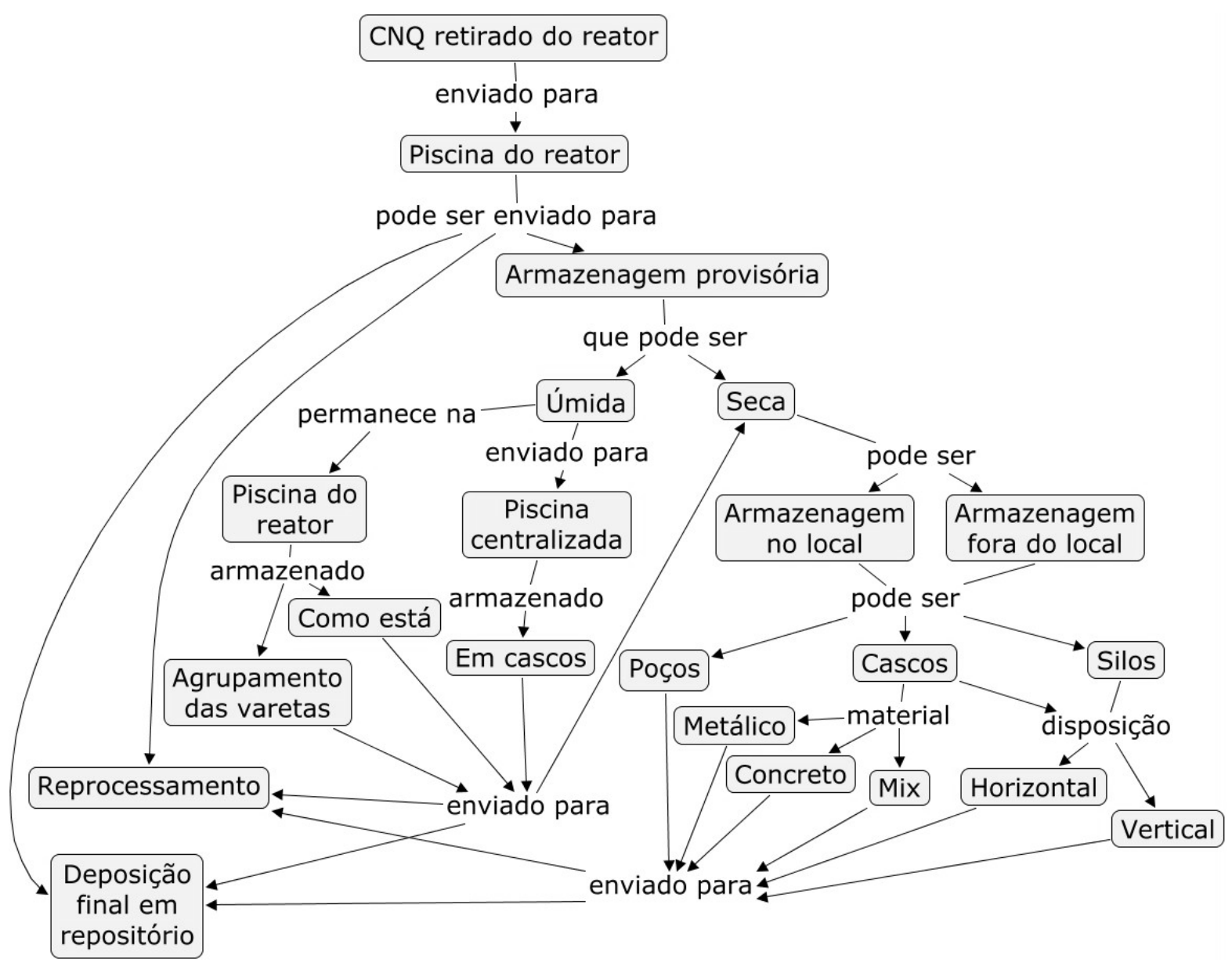

Figura 1 - Roteiro conceitual da armazenagem provisória de CNQ

Fonte: Romanato e Rzyski (2006) 
No Brasil, em princípio, o reprocessamento não faz parte dos planos para a etapa do ciclo do combustível nucelar que envolve o CNQ de origem nacional. É necessário, portanto, armazená-lo de modo seguro, ter fácil acesso a ele e, se necessário, poder deslocá-lo, dentro da instalação de origem ou para fora da mesma, de modo simples e econômico.

Em 2007, a CNEN informou em relatório específico que no Brasil ainda se aguarda uma decisão definitiva quanto ao destino do CNQ: reprocessamento ou deposição como rejeito radioativo. Essa decisão demandará tempo, mas já se aventa a hipótese de que, quando a quantidade de CNQ armazenado no reator ficar próximo da capacidade máxima da piscina, será necessária a construção de uma instalação de armazenagem em via úmida ou em via seca. Em 2008, a CNEN continuava aguardando um consenso mundial, referente a que atitude deveria ser tomada com relação ao CNQ, citando que, para as usinas nucleares Angra 1, 2 e 3, a Eletronuclear - Eletrobrás Termonuclear S/A conjetura a construção de uma instalação de armazenagem úmida adicional às piscinas existentes em Angra 1 e 2.

A maior parte dos países que possui combustível nuclear queimado guarda-o em piscinas, "via úmida”, ou em instalações que não demandam água como meio refrigerante, denominadas “via seca”, até que seja construída uma instalação em que seja possível depositá-lo definitivamente - “repositório” (Dionisi, 1999; Amaral et al., 2007). Até lá, o CNQ tem sido mantido em locais provisórios.

A armazenagem em via úmida, daqui em diante, será denominada simplesmente "armazenagem úmida” e a de via seca, "armazenagem seca”.

A prática mundial mostra que o CNQ retirado do núcleo do reator é armazenado temporariamente em piscinas existentes nos reatores comerciais ou de pesquisa. Após certo tempo, o combustível pode ser removido destas piscinas e transferido para outras instalações de armazenagem úmida ou seca, também temporárias (Cochran; Tsoulfanidis, 1992).

Nos sistemas de armazenagem seca, depois do período em que o CNQ fica armazenado em piscinas, os níveis de emissão de calor e radioatividade estão bem mais baixos do que aqueles imediatamente após a retirada do núcleo do reator (IAEA, 2005). O CNQ é transferido do sistema submerso para recipientes metálicos cilíndricos que, após serem drenados, preenchidos com gás inerte e lacrados, podem ser transportados para uma instalação específica ou então colocados diretamente sobre um piso de concreto ou em silos e, assim, permanecem armazenados com segurança (IAEA, 2000; Ahmed et al., 2003; 
Biro e Rodna, 2003). É possível, também, armazenar o CNQ em cilindros de concreto com revestimento interno em aço. Esses recipientes podem permanecer em abrigos, como os anteriores, ou ao ar livre em instalações adequadas para esta finalidade (IAEA, 2003). Na Figura 2 é mostrada a seqüência da retirada do CNQ da piscina do reator e posterior armazenagem em casco.

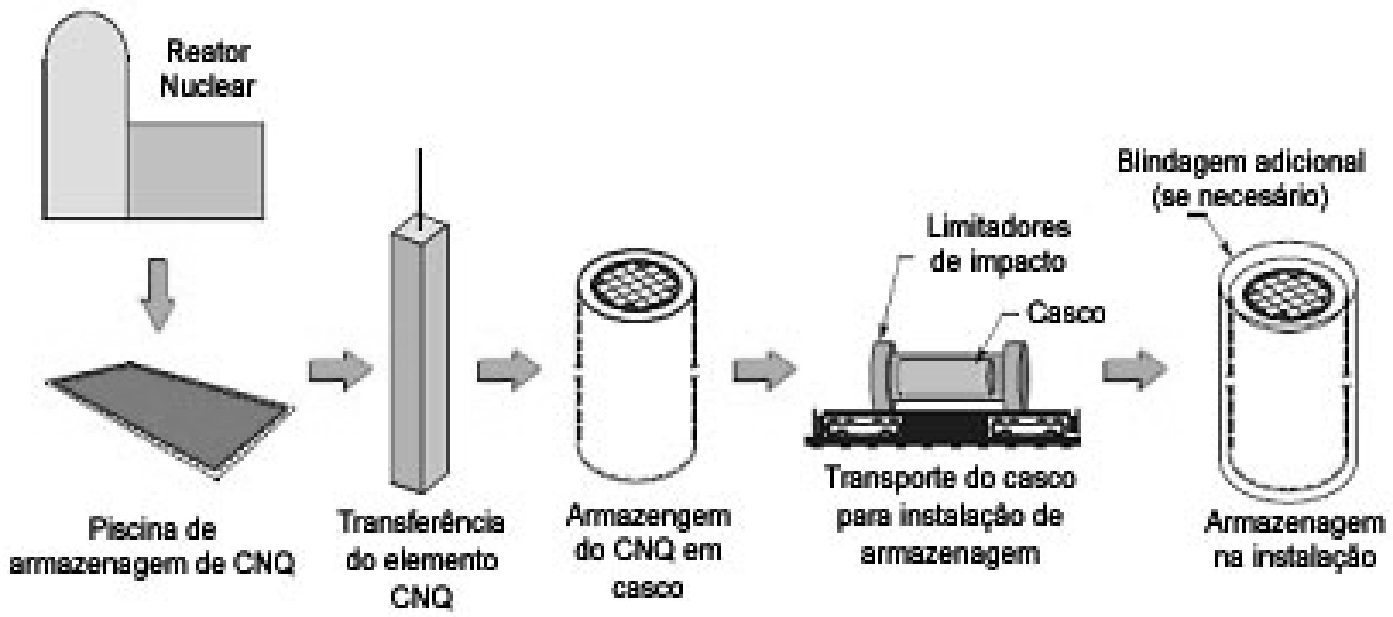

Figura 2 - Seqüência de retirada do CNQ e armazenagem em casco.

Fonte: Adaptado de Forsberg (2004)

Uma prática comum no parque nuclear de alguns países é a armazenagem seca nas áreas dos próprios terrenos das usinas nucleares cuja capacidade de armazenagem em piscinas esteja comprometida, por causa do grande volume de CNQ acumulado. O licenciamento de instalações de armazenagem seca de CNQ que é efetuado pela United States Nuclear Regulatory Commission (USNRC - Comissão Regulatória Americana) é de 20 anos, podendo ser prorrogável por outros períodos iguais (USNRC, 2009a). A USNRC (2009a) também considera que a armazenagem seca é mais segura que aquela feita em piscinas, porque não ocorre corrosão provocada pela água.

A tecnologia de armazenagem seca na própria instalação do reator já é tecnicamente comprovada e mostrou ser radiológica e fisicamente segura (IAEA, 1988). O esgotamento da capacidade de armazenagem úmida, quando inexiste o recurso da armazenagem seca, pode forçar a interrupção da operação de centrais nucleares e, conseqüentemente, a geração de energia elétrica.

O combustível nuclear queimado sempre foi uma fonte valiosa de urânio e plutônio e, anteriormente, visualizava-se que a extração desses nuclídeos, por meio do 
reprocessamento do CNQ, fosse a única maneira de sustentar a indústria nuclear comercial, sem exaurir rapidamente os depósitos de urânio natural. Hoje em dia, porém, com a contenção de alguns programas nucleares e a descoberta de novas minas de prospecção de urânio, aqueles paises que planejavam reprocessar ou que reprocessavam CNQ, reanalisaram seus programas e a tendência de armazenagem em longo prazo torna-se cada vez mais comum.

O panorama mundial mostra que é imperativo encontrar uma solução alternativa para a armazenagem temporária úmida até o destino definitivo do CNQ, que em muitos países já passou a ser considerado rejeito radioativo.

Os métodos mundialmente utilizados para armazenagem úmida e seca de CNQ foram descritos por Romanato (2005), que mostrou as vantagens e desvantagens em cada caso, bem como os custos para cada tipo de instalação. O autor concluiu que o método mais adequado de armazenagem nas instalações nucleares é a via seca em cascos metálicos ou de concreto, corroborando com estudos da IAEA (1999), e que é também aplicável às usinas brasileiras do tipo PWR.

Este trabalho apresenta um método para armazenagem temporária seca em cascos que poderia ser utilizada na Central Nuclear Almirante Alvaro Alberto em Angra dos Reis, RJ.

Os cascos de armazenagem seca, além de servir para o transporte e armazenagem, podem ser aplicadas como suporte para deposição definitiva do CNQ, de acordo com a opção escolhida. Os cascos devem atender requisitos específicos quanto à mobilidade, recuperação do CNQ durante/após a armazenagem, instalação e operação, meio ambiente (ABNT, 2005), como auxiliar no descomissionamento dos reatores, economia e segurança da deposição, e a aceitação do público.

A inserção do CNQ nos cascos é uma operação crítica. Os cascos podem ser carregados sob imersão na piscina de resfriamento e a tampa colocada com o casco ainda submerso. Após a retirada desse conjunto da piscina é realizada uma seqüência de operações como: drenagem da água, secagem do CNQ, selagem da tampa, inserção de parafusos na segunda tampa, descontaminação da superfície externa, etc.

A utilização de cascos de armazenagem seca ao redor do mundo é cada vez maior. Alguns projetos de reatores europeus (PWR de 1300MW, na França, e 1400MW, na Bélgica) (IAEA, 2005), adaptaram uma técnica de carregamento de CNQ por meio de trilhos para um poço na piscina de resfriamento. Esse tipo de carregamento por controle remoto reduziu ainda mais a exposição dos operadores à radiação. 
No Brasil, a primeira experiência da utilização de cascos de armazenagem seca para transporte de CNQ ocorreu em 16 de setembro de 1999, quando 127 elementos de combustível nuclear queimado, que haviam sido acumulados desde a inauguração, em 1957, do reator IEA R-1 do antigo Instituto de Energia Atômica (IEA), hoje IPEN, começaram a ser retirados. A piscina do reator ficou praticamente tomada por CNQ de origem norte-americana e, por meio de um acordo entre o Brasil e Estados Unidos da América (EUA), foi feita a repatriação ao país de origem de forma voluntária. Dos 127 elementos combustíveis queimados utilizados desde o início das operações do reator, 87 ocupavam grande parte da piscina de armazenagem. Outros 40 elementos estavam armazenados em via seca, em cavidades horizontais, localizadas na parede de concreto ao redor do núcleo do reator.

Para transportar o CNQ para a sua origem foram utilizados cascos especiais de transporte, desenvolvidos na Alemanha pela empresa GNS, com capacidade para armazenar 33 elementos por casco (Figuras 3 e 4) (Maiorino et al., 2000). Todo o ônus quanto ao arrendamento dos cascos para o transporte do CNQ enviado foi pago pelo governo dos Estados Unidos.

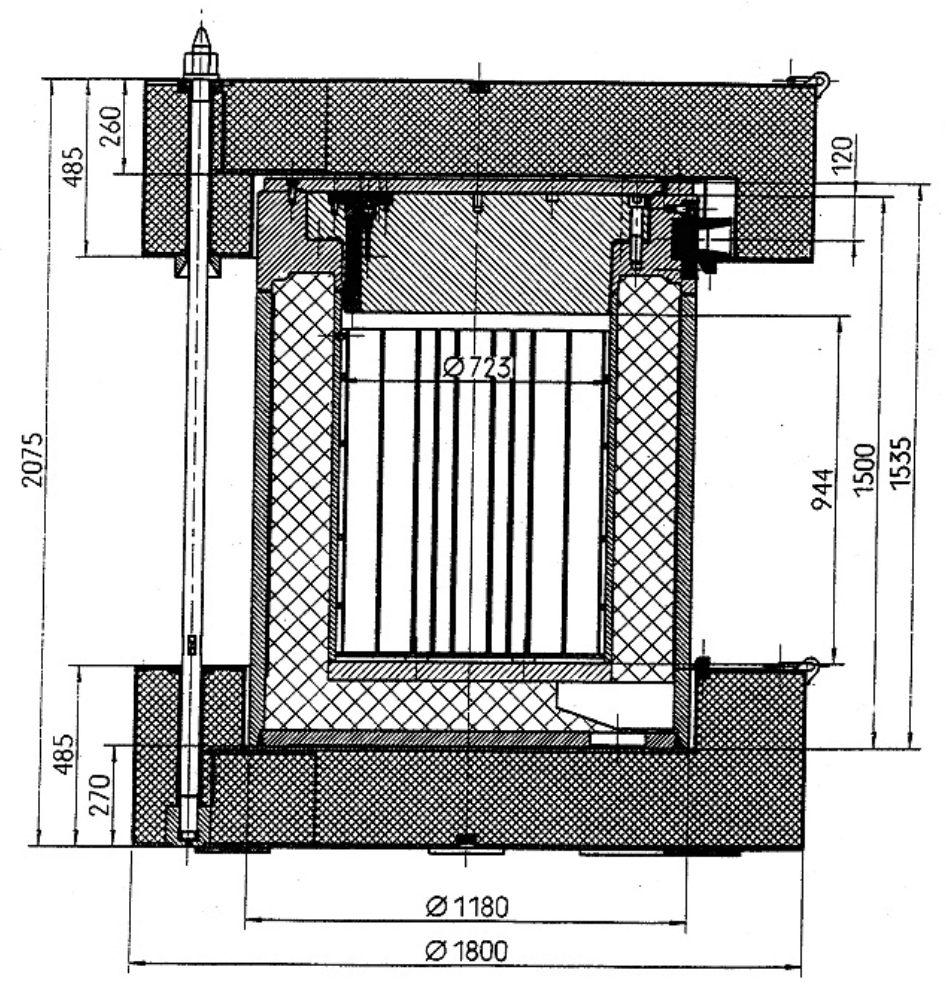

(dimensões em milímetros)

Figura 3 - Desenho de casco GNS-16 utilizado pelo IPEN, em 1999, para transportar CNQ de origem americana do Brasil para os EUA.

Fonte: Maiorino et al. (2000) 


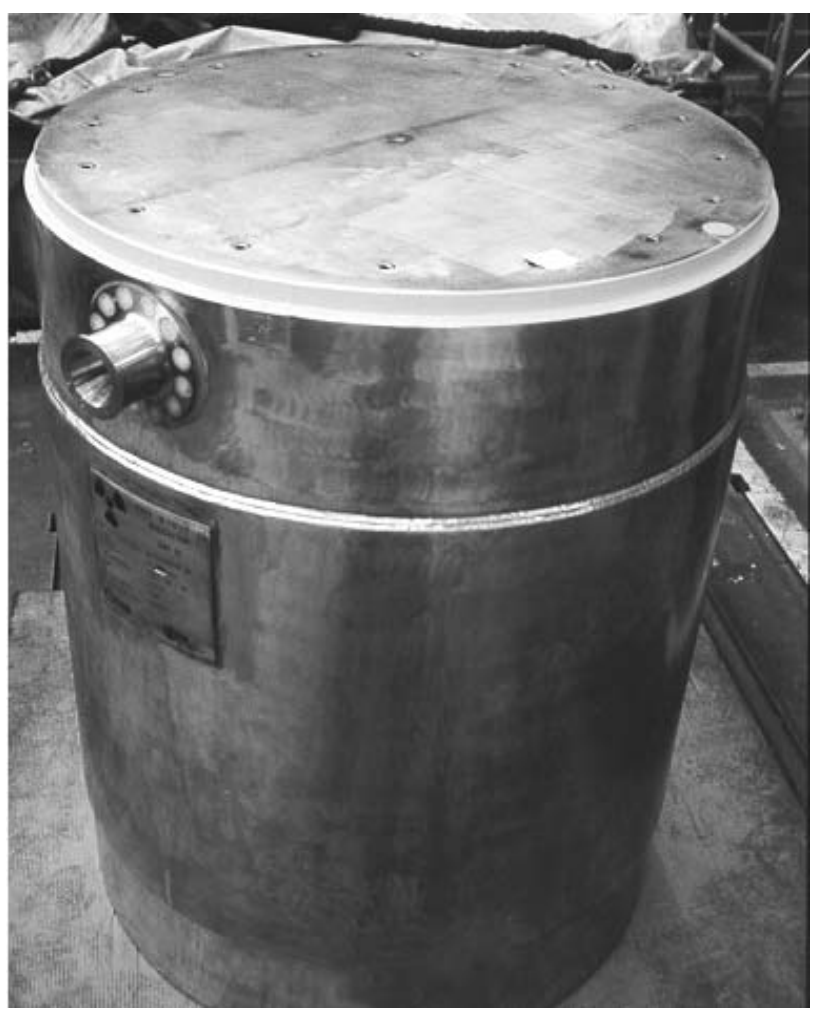

Figura 4 - Casco GNS-16 utilizado pelo IPEN, em 1999, para transportar CNQ de origem americana do Brasil para os EUA.

Fonte: DOE (2001)

Para os 127 elementos CNQ foi necessário utilizar quatro cascos, dois do modelo GNS-11 e dois do modelo GNS-16. A diferença entre ambos, quando posicionados na vertical, é a altura. O casco modelo GNS-11 permite a armazenagem de 33 elementos combustíveis com 630mm de comprimento e o GNS-16, 33 elementos com 915mm de comprimento. O transporte rodoviário, do IPEN para o porto de Santos, envolveu contêineres para manter os cascos protegidos, e foi realizado no dia 3 de novembro de 1999. Os cascos foram embarcados em um navio especialmente preparado para o transporte marítimo desta carga. (Frajndlich, 2008)

Outro transporte de CNQ do Brasil para os Estados Unidos ocorreu em 14 de novembro de 2007. Desde 1999, outros 33 elementos combustíveis queimados de origem americana estavam armazenados na piscina do reator IEA R-1. Neste transporte foi utilizado um casco modelo LWT da empresa NAC (CNEN, 2008). Conforme o Ministério de Ciência e Tecnologia (2008), nesta mesma data, além dos 33 elementos CNQ do reator IEA-R-1, outras fontes exauridas provenientes do Instituto de Pesquisa Energéticas e Nucleares e do Centro de Desenvolvimento de Tecnologia Nuclear (CDTN), foram 
embarcados para os Estados Unidos. O CNQ foi enviado para o Laboratório de Savannah River.

Em breve, a piscina do IEA R-1 atingirá novamente um limite tal, que será necessário ter uma alternativa para a armazenagem do CNQ. Estudos realizados pelo IPEN (Silva et al., 2005), em conjunto com o Centro de Desenvolvimento de Tecnologia Nuclear - CDTN (Soares; Silva, 2004) e outros órgãos da América Latina, com financiamento da IAEA (Maiorino et al., 2002), analisaram qual seria o destino do CNQ gerado pelos reatores de pesquisa do tipo MTR (Material Test Reactor). Esses estudos não analisaram alternativas para o destino do CNQ gerado em reatores nacionais do tipo PWR. Entre os reatores PWR no Brasil estão os de Angra 1, 2 e 3 e o futuro reator de propulsão do Centro Tecnológico da Marinha em São Paulo (CTMSP). O governo brasileiro está propondo a construção de outros reatores nucleares do tipo PWR para geração de energia elétrica e que também terão que gerenciar o CNQ gerado.

Atualmente, nenhuma empresa no Brasil desenvolve cascos para CNQ com vistas à futura necessidade de armazenagem e transporte. Por causa das características do combustível irradiado, este desenvolvimento envolve uma série de análises durante a concepção do projeto do casco.

O sistema de armazenagem seca, que compreende o manuseio do CNQ, embalagem, transferência e a armazenagem propriamente dita, deve ser projetado de modo a:

- proporcionar a contenção adequada do CNQ;

- manter sub-criticalidade com geometria;

- dissipar o calor gerado internamente durante o decaimento dos produtos de fissão presentes no CNQ;

- possuir capacidade para blindar a radiação gama e nêutrons;

- atender as normas de proteção radiológica para proteção dos trabalhadores e do público contra as radiações.

O CNQ contém uma diversidade grande de radioisótopos que emitem radiações alfa, beta, gama e nêutrons com diversas energias. Após 10 anos de imersão do CNQ na piscina, vários elementos radioativos de meia-vida inferior a cinco anos decaem. O mesmo não ocorre com radionuclídeos com meias vidas mais altas e é indispensável, portanto, blindar a radiação emitida, principalmente a radiação gama e nêutrons. 
Para blindar a radiação gama, resultante do decaimento dos radionuclídeos ou reações entre os nêutrons e a blindagem são usados materiais de alta densidade, como aço estrutural e chumbo (Severa e Bar, 1991). Os nêutrons podem ser absorvidos por materiais altamente hidrogenados e com dispersões de boro (Hayashi et al., 2006).

A estrutura do casco deverá ser projetada de modo a resistir às condições normais de transporte e armazenagem (USNRC, 2009), enquadrar-se nas normas de transporte de recipientes para material radioativo da CNEN, NE - 5.01 (1988), e deve passar por ensaios de demonstração da conformidade. Necessita, ainda, atender à norma da de transporte da CNEN, NE - 5.02 (1986) que padroniza o recebimento, armazenagem e manuseio de elementos combustíveis de usinas nucleoelétricas.

Na análise da resistência térmica do casco, em virtude de sua estrutura, devem ser levadas em consideração três fontes de calor: aquele gerado internamente pelo CNQ, o calor ambiente da insolação (caso o casco seja armazenado ao ar livre) e o calor gerado por um incêndio eventual ao redor do casco. Além disso, devem ser previstos e elaborados planos de emergência que contemplem os itens seguintes: descrição da instalação, tipos de radionuclídeos existentes, classificação e formas de detecção de acidentes, mitigação das conseqüências, responsabilidades, notificação e coordenação, treinamento, condições de segurança, exercícios periódicos, impactos ao meio ambiente e assistência externa. Outros requisitos importantes são: a possibilidade de realização da manutenção do casco e, caso necessário, a facilidade da descontaminação (USNRC, 2009a).

As vantagens e desvantagens dos diversos tipos de casco, existentes e propostos, deverão ser analisadas para que se possa optar pela melhor proposta. Atualmente existem cascos metálicos, de concreto e mistos (metal e concreto). Os metálicos podem ser de aço, ferro fundido, chumbo, urânio exaurido (empobrecido) ou cobre. Os cascos de concreto podem ter paredes com várias espessuras e formulações (cimento-pedra-areia-água e ferro para armação). Os cascos mistos são confeccionados com vários materiais e envolvem, desde camadas alternadas de concreto e aço (Göhring et al., 2005) até combinações de misturas metalo-cerâmicas (cermets), inclusive com a inclusão, nas dispersões cerâmicas, de dióxido de urânio exaurido - $\mathrm{DUO}_{2}$ (Forsberg; Haire, 2002), conforme mostra a Figura 5 (Forsberg, 2003), embora este seja material sob salvaguardas na maior parte do mundo. 


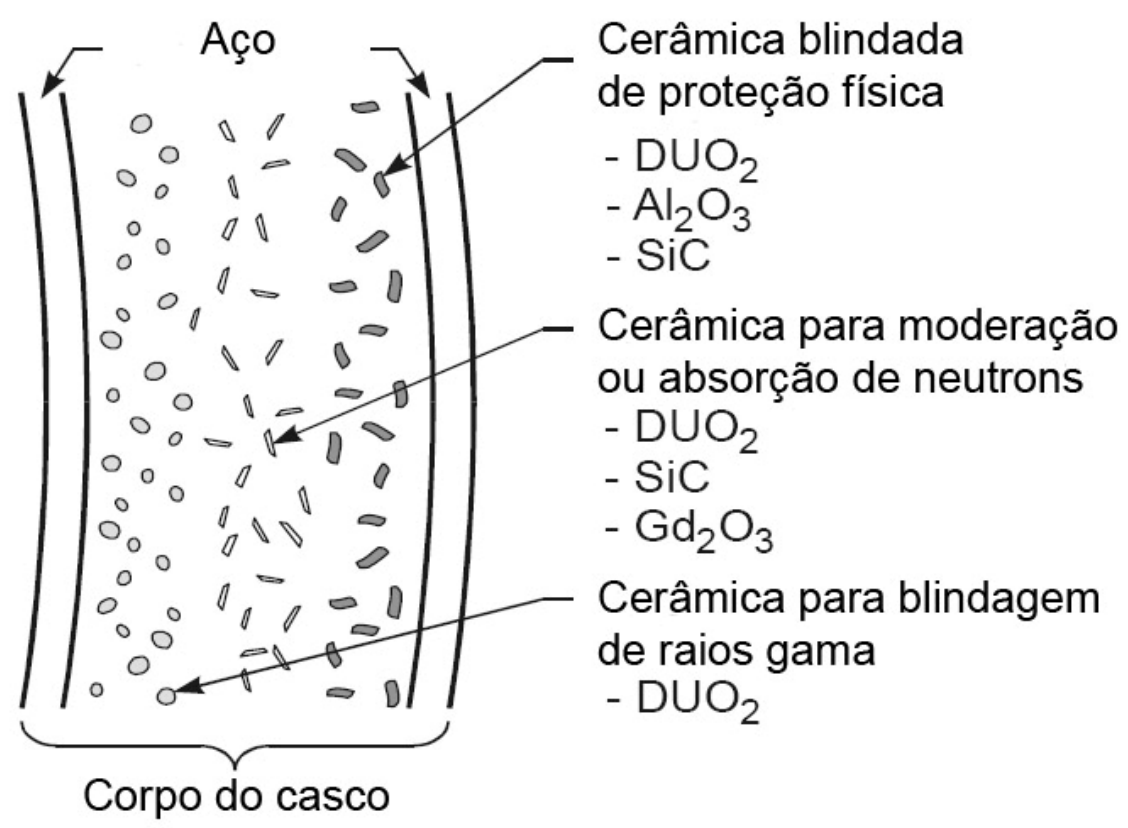

Figura 5 - Exemplo de seção de um casco com dispersão cerâmica.

Fonte: Adaptado de Forsberg (2003)

Um casco deve reunir as condições técnicas para receber o CNQ, permitir seu transporte em condições seguras e, conforme já exposto, armazená-lo pelo tempo desejado na instalação de armazenagem temporária. De acordo com o tipo de casco, vários aspectos que conjugam a fabricação do mesmo, o transporte e a armazenagem são relevantes: a qualidade dos insumos para a fabricação do casco, contenção e blindagem, análise térmica e estrutural, controle da criticalidade, inspeção e manutenção, licenciamento, além de ter que atender as normas e regulamentos de transporte e armazenagem de cascos em função do programa nuclear de cada país (Shappert et al., 1998). Todo este panorama pode ser adotado também no Brasil.

A instalação de armazenagem provisória deve ser segura, estável e permitir que o combustível nuclear queimado seja guardado de modo seguro antes de ser enviado para reprocessamento, ou disposto como rejeito radioativo. Como em outros sistemas de engenharia, a segurança na operação e a manutenção desta instalação dependem, em grande parte, do projeto e construção adequados. O maior objetivo é garantir que o CNQ seja recebido e armazenado na instalação e que nestes processos não haja riscos quanto à saúde e segurança dos trabalhadores, e da população circunvizinha. (IAEA, 1994a) No caso de instalação para armazenagem seca, a mesma deve ter uma série de características entre as quais: possibilitar a movimentação dos cascos; ter piso de concreto reforçado para 
suportar o peso; ser aberta (os cascos ficam à mercê de intempéries) ou fechada (os cascos de armazenagem ficam dentro de um prédio coberto com estrutura específica), possuir segurança física e de radioproteção, etc.

A análise dos impactos ambientais postulados para uma instalação provisória de armazenagem de CNQ é de importância significativa, visa assegurar seu pleno funcionamento (NBR ISO 14004:2005 - ABNT, 2005) e demonstrar, com um plano de gestão ambiental, que a instalação opera de forma a preservar o meio ambiente. Uma análise inicial dos impactos ambientais postulados para o transporte de CNQ para a instalação de armazenagem foi feita por Romanato e Rzyski (2005) e será discutida neste trabalho. 


\subsection{OBJETIVO}

Atualmente, nenhuma empresa no Brasil, desenvolve cascos de armazenagem para CNQ, portanto, o país não possui esse tipo de recipiente móvel que permite manter o CNQ isolado, com segurança e por longo tempo. A mobilidade do casco permite deslocálo para outras instalações de armazenagem (talvez centralizadas) a um custo mais baixo do que a retirada do CNQ da piscina por meio de um casco de transferência e depois a colocação deste combustível em outro casco que tem utilidade como contenção de transporte (IAEA, 2007).

Nesse contexto, o objetivo desta tese é estudar as alternativas viáveis que subsidiem a confecção de um casco totalmente nacional que sirva para armazenagem e transporte de CNQ de reatores PWR bem como a instalação de armazenagem e o meio de transporte. As usinas nucleares comerciais brasileiras do tipo PWR consideradas aqui para tal propósito são as da Central Nuclear Almirante Álvaro Alberto (CNAAA) localizadas em Angra dos Reis, Rio de Janeiro, isto é Angra 1 e 2 e a usina Angra 3 que brevemente será construída.

O casco precisa ser projetado de tal modo a receber o CNQ na instalação do reator, ser fechado e deslocado para outros locais fora do reator e ser depositado em instalações para armazenagem seca. Por este motivo deve atender a requisitos básicos como conter o material radioativo - CNQ (contenção), limitar a radiação emanada pelo CNQ (blindagem), prevenir a possibilidade de ocorrência de criticalidade, resistir ao calor gerado pelo CNQ e dissipá-lo de forma a manter a temperatura do CNQ dentro do limite de segurança. O burnup aqui considerado foi de $33 \mathrm{GWd} / \mathrm{tU}$.

As etapas para alcançar o objetivo proposto são:

a. Identificar as características técnicas dos tipos de cascos existentes no mundo para armazenagem de CNQ e sugerir o tipo de casco e as dimensões mais apropriadas para a necessidade brasileira;

b. Caracterizar o CNQ gerado nos reatores nucleares nacionais do tipo PWR (Angra 1, 2 e 3), para poder escolher o tipo de casco;

c. Propor um projeto conceitual do casco, mais adequado para o CNQ de reatores nucleares PWR nacionais e otimizar suas dimensões em função das dimensões dos elementos combustíveis e burnup; e, 
d. Reunir as informações sobre os tipos de instalações de armazenagem seca para CNQPWR existentes no mundo e com estes dados sugerir características técnicas para a armazenagem de CNQ-PWR de Angra;

e. Caracterizar a instalação de armazenagem quanto a:

- Dimensões necessárias para a proteção do CNQ nas décadas subseqüentes à sua retirada da piscina do reator e colocação em cascos;

- Disposição dos cascos nesta instalação (na vertical ou na horizontal; acima ou abaixo do nível do solo);

\subsection{ORIGINALIDADE}

No exterior existem diversos modelos de cascos e instalações de armazenagem intermediária/temporária para CNQ gerado em reatores de potência. No Brasil, estão em andamento estudos para determinar os prováveis tipos de cascos para CNQ gerado por reatores de pesquisa (Silva et al., 2005; Soares; Silva, 2004; Maiorino et al., 2002), e ainda não foi desenvolvido nenhum estudo sobre cascos autóctones de armazenagem de combustível nuclear de reatores nacionais do tipo PWR. Por este motivo, o tema da presente tese, além de proporcionar subsídios para a construção de cascos nacionais para armazenagem de CNQ provenientes de reatores do tipo PWR já existentes no País, poderá ser adequado, também, para combustíveis de outros reatores que venham a ser instalados no futuro.

A armazenagem seca de CNQ em cascos como a proposta nesta tese, em função de toda a pesquisa realizada em literatura, atenderá a certos quesitos como: contenção de combustível; criticalidade; troca de calor; estrutura; mobilidade; proteção radiológica; os princípios de segurança e a possibilidade de armazenagem do CNQ-PWR por um período de 20 a 40 anos como recomenda a USNRC (2009a), para que os órgãos competentes nacionais tenham mais tempo para definir o local de armazenagem definitiva desse tipo de combustível. 
2 REVISÃO DA LITERATURA 


\section{REVISÃO DA LITERATURA}

Ao longo deste capítulo é citada a literatura mais importante para o escopo do presente trabalho.

Komarowskii (1961) discorreu sobre alguns materiais de blindagem para reatores nucleares e suas especificações. Estes dados são importantes para a composição do projeto do casco para CNQ-PWR nacional complementados com dados de literatura mais recente.

Os princípios fundamentais, científicos e tecnológicos dos sistemas de reatores nucleares, tais como processo de fissão e radiações associadas, foram definidos por Glasstone e Sesonske (1975).

Outra literatura importante sobre os conceitos introdutórios de análise das reações nucleares, modelos de transporte de nêutrons e análise do núcleo do reator, onde é gerado o CNQ, foi feita por Duderstadt e Hamilton (1976)

Em 1978, Held e Hintermeyer descreveram alguns aspectos necessários para estimar os custos de projeto e construção de instalações independentes de armazenagem de CNQ. Mostraram que o custo depende: da capacidade e tipo de instalação (cascos ou módulos); do método de refrigeração do CNQ (água ou ar); dos diferentes projetos dos prédios (paredes com ou sem blindagem, subterrâneas ou não, com pontes rolantes ou veículos movimentadores, etc.); da redundância de equipamentos; e, do programa de garantia da qualidade.

Saaty discutiu em seu livro, publicado em 1980, os métodos aproximados nos quais quantifica e classifica diferentes alternativas, para a tomada de uma decisão por meio da aplicação de “priorização de vetores”. A priorização pode ser feita por meio do Processo Hierárquico Analítico - Analytical Hierarchy Process (AHP), que consiste de modelagem de problemas complexos em uma estrutura hierárquica que mostre as relações entre as metas, os critérios que exprimam os objetivos e sub-objetivos, e as alternativas que envolvam a decisão. As informações são muito úteis para o desenvolvimento de projetos, mormente na área nuclear.

A Lei ordinária n. 6.938, de 31 de agosto de 1981, estabeleceu a Política Nacional do Meio Ambiente, seus mecanismos de formulação e aplicação cujo objetivo é a preservação, melhoria e recuperação da qualidade ambiental. 
Best et al. (1982) patentearam, pela Nuclear Assurance Corp. (NAC), um casco para transporte de combustível nuclear queimado que possui múltiplos munhões de elevação. O casco também incluiu um acoplamento de elevação e limitadores de impacto nas suas extremidades. O acoplamento de elevação é o dispositivo que permite o engate entre o gancho de uma ponte rolante e os munhões do casco e o manuseio do casco carregado com CNQ.

Em Relatório Técnico, publicado em 1983, a International Atomic Energy Agency, IAEA (Agencia Internacional de Energia Atômica) apresentou um levantamento realizado por países membros da Agência sobre o manuseio e armazenagem de rejeitos de atividade alta, imobilizados e acondicionados em cilindros e neste conjunto está incluído o combustível queimado. O relatório apresenta os princípios importantes para condicionar rejeitos, descreve equipamentos e instalações para manuseio e armazenagem. Discute também, aspectos de segurança e econômicos, considerados no projeto e operação dessas instalações. Cita que, caso necessário, a segurança da instalação deve ser demonstrada ao público, de modo que toda a população seja esclarecida sobre os riscos da operação que devem ser mínimos. A segurança durante a armazenagem requer que a contenção proporcionada pela instalação previna a liberação de produtos de fissão ao meio ambiente, não só em situação normal de operação, como também em condições anormais como acidentes resultantes de falhas internas ou externas à instalação. Conforme o relatório, as falhas internas poderiam ser falhas no equipamento de ventilação, instrumentação e controle; perda na capacidade de resfriamento, no fornecimento de energia, falha estrutural na contenção e erro humano; ou externas tais como condições climáticas extremas (temperatura, ventos, neve, gelo, enchentes), avalanches, terremotos, explosões, impacto de mísseis (incluindo quedas de aviões) e sabotagem ou outros atos hostis provocados por estranhos.

Hondorp (1984) patenteou, pelo Department of Energy (DOE), um material composto por 95 a $97 \%$ de óxido de silício $\left(\mathrm{SiO}_{2}\right)$ e 5 a 3\% de silicato de sódio $\left(\mathrm{Na}_{2} \mathrm{SiO}_{3}\right)$ para blindagem contra nêutrons e raios gama em cascos para CNQ. O autor detalha materiais normalmente utilizados para blindagens, que ele se propôs a substituir.

Em 1985, a CNEN publicou a norma NE-6.05 que estabelece critérios gerais e requisitos básicos relativos à gerência de rejeitos radioativos, ou seja, o conjunto de atividades administrativas e técnicas envolvidas no manuseio, acondicionamento, inserção, transporte, armazenamento, controle e deposição de CNQ. Essa norma está em consonância com os requisitos da IAEA. 
A norma NE-5.02, publicada pela CNEN, em 1986, estabeleceu os requisitos para o transporte, recebimento, armazenagem e manuseio seguros de elementos combustíveis de usinas nucleoelétricas e é aplicada ao trabalho do indivíduo que participe dessas atividades.

Lusk e Ridihalgh (1987) solicitaram patente, pela Mitsubishi Heavy Industries $L t d$., de um casco de transporte e armazenagem de combustível nuclear queimado. Nela detalham as denominações de cada item de um casco de armazenagem de CNQ. O casco pode ser armazenado na vertical ou horizontal e são apresentados detalhes construtivos de cestos, tampas e do corpo dos cascos.

Em 1988, a IAEA publicou um relatório que apresenta a experiência dos países usuários de armazenagem seca ou úmida de CNQ. Nesse relatório a IAEA chegou à conclusão que a armazenagem seca seria mais confiável, embora a armazenagem úmida ainda opere com uma tecnologia segura.

Na norma NE- 5.01, publicada pela CNEN, em 1988, foram estabelecidos os requisitos de radioproteção e segurança no transporte de material radioativo e é aplicada no transporte por terra, água ou ar; no projeto, fabricação ensaios e manutenção de um casco de transporte e armazenagem; e, na preparação, expedição, manuseio, recebimento e armazenagem do casco.

Em 1989, a CNEN publicou a norma NE-6.06 que estabelece os requisitos mínimos aplicáveis ao processo de seleção e escolha de locais para depósitos de rejeitos radioativos, tendo em vista garantir o confinamento seguro desses materiais pelo tempo que se fizer necessário com o objetivo de proteger o homem e o meio ambiente.

Wells (1990) solicitou patente, pela empresa americana NAC, de um cesto para armazenagem de CNQ para um casco de transporte, com eficiente dissipação de calor, blindagem contra nêutrons e alta resistência estrutural.

Blum et al.(1991) patentearam, pela empresa francesa Transnucleaire, um cesto de armazenagem para cascos de CNQ. Os cestos são fabricados em materiais que tem a função estrutural de condução térmica e proporcionam a absorção de nêutrons.

Severa e Bar (1991) apresentaram os fundamentos da descontaminação de superfícies sólidas e água e revisam as práticas e meios de descontaminação principais. A ênfase no trabalho dos autores foi a descontaminação dos vasos de reatores e de outras superfícies.

Cochran e Tsoulfanidis (1992) incluíram em seu livro um capítulo sobre a gerência de rejeitos de atividade alta em uma série de tópicos referentes ao CNQ como: 
armazenagem, radioatividade, calor de decaimento, transporte e a gerência. Os autores ressaltaram, ainda, a importância das emissões radioativas emitidas pelo CNQ referente a três grupos de radioisótopos: produtos de fissão, actinídeos e produtos de ativação. Os dados são úteis para o cálculo das dimensões dos cascos destinados a armazenagem seca.

Em relatório publicado pela IAEA (1994), foi proposta e desenvolvida uma metodologia para a análise dos custos envolvidos com a armazenagem de CNQ. Esta metodologia envolve a melhoria da instalação de armazenagem existente, o aumento das instalações ou criação de uma nova instalação no sítio do reator, ou, a armazenagem em instalações fora desse sítio. Com base na análise dos dados pode-se optar por uma instalação úmida ou seca, ao caracterizar cada custo em categorias, analisar a economia dos valores envolvidos até chegar a um valor total ótimo. O relatório incluiu um projeto de construção, licenciamento, manutenção e descomissionamento da instalação de armazenagem.

A IAEA (1994a) publicou um guia de segurança para auxiliar no projeto, operação e na segurança de instalações de armazenagem provisória de combustível nuclear queimado. Os princípios estabelecidos nesse guia são resultado de consenso internacional e apresentam características consideradas efetivas para manter o combustível em um nível subcrítico, remover o calor residual, propiciar proteção contra radiação e manter a contenção dos materiais radioativos durante a vida da instalação.

A publicação do Nuclear Energy Institute (1997), uma organização norteamericana ligada à área nuclear, permitiu que se avaliasse a situação dos reatores nucleares construídos pela ex-União Soviética nos países do Leste europeu e a destinação do CNQ. Após o acidente da unidade 4 de Chernobyl, em 1986, surgiu uma grande preocupação em torno dos reatores nucleares do tipo RBMK. O documento cita que foi iniciado um estudo sobre as usinas nucleares construídas pelos russos, no qual são enfatizados os aspectos de segurança e indicados os pontos positivos e as deficiências principais de cada tipo de reator existente. Depois que os países que possuíam esses tipos de reatores traçaram sua prioridade com relação à segurança, foi verificado que a gerência do CNQ era uma prioridade para todos. O CNQ russo proveniente dos reatores VVER-1000 era armazenado na instalação do próprio reator e aguardava reprocessamento em Zheleznogorsk, Rússia. O CNQ dos reatores tipo RBMK não era reprocessado por causa do alto custo. Esse combustível é armazenado na própria instalação do reator, mas uma instalação centralizada para armazenagem seca está em fase de construção. A publicação refere também que na Ucrânia, a construção da instalação de armazenagem temporária seca na central de 
Zaporizhzhya, e as futuras instalações secas de Rovno e Chernobyl, abrigarão o CNQ gerado por essas centrais. Cita ainda que, na Lituânia, a central de Ignalina, após um contrato com a empresa alemã GNB, recebeu 20 cascos do tipo CASTOR e, em 2001, começou a receber um lote de mais 40 cascos do tipo CONSTOR para armazenagem do CNQ. Também mostra que a Armênia assinou um contrato com a França para a construção de uma instalação de armazenagem seca na central de Metsamor. Os outros países do leste europeu, conforme consta na publicação, adotaram posições semelhantes quanto à construção de instalações de armazenagem seca em cascos ou em poços, para o CNQ gerado.

Pruvost e Paxton (1996) editaram o documento técnico que cita informações relacionadas aos princípios, práticas com apresentação de normas, práticas administrativas, práticas técnicas, validação, interação entre os procedimentos de salvaguardas e o controle de criticalidade, instrumentação, garantia da qualidade, métodos probabilísticos; e, a vivência em segurança com acidentes ocorridos quanto à criticalidade nuclear. É um guia geral para órgãos reguladores.

Jones et al. (1996) patentearam, por meio da empresa Pacific Nuclear System, um casco metálico de transporte e armazenagem de CNQ.

Ritchie (1998), em Boletim da IAEA, abordou sobre a importância na armazenagem de CNQ de reatores de pesquisa.

Em 1998, Shappert et al. editaram um manual preparado para o Oak Ridge National Laboratory sobre embalagens de armazenagem de material radioativo. São abordados materiais radioativos, rejeitos e combustível queimado, sendo que para cada tipo de material a ser armazenado, para a embalagem, deve haver diferentes características térmicas, de blindagens e, se necessário, para se evitar criticalidade. Este manual serve de guia no projeto, teste, certificação e operação de embalados para esses materiais

Dionisi (1999) analisou a possibilidade da construção de instalações de armazenagem de CNQ em diversos tipos de terrenos geológicos. As tendências e atividades, com relação ao CNQ, nos países da União Européia, foram analisadas pelo autor, que observou que uma grande maioria não pensa mais em reprocessamento de combustível nuclear. Ilustrou também as salvaguardas, armazenagem temporária - úmida e seca, e fez uma análise dos repositórios para deposição direta que são locais de armazenagem profundos (centenas de metros abaixo), nos quais poderiam ser armazenados tanto o CNQ, quanto os rejeitos de atividade alta. Até a data de emissão do relatório não existia nenhum repositório efetivamente construído e licenciado para receber esse tipo de 
material. Dionisi afirmou que a Alemanha estaria estudando a possibilidade de usar uma mina de sal para construir um local para deposição do CNQ e que a Suécia pretendia construir um repositório a 500m de profundidade sobre um leito rochoso em local que ainda não havia sido determinado.

Em 1999, o Ministério de Indústria y Energia da Espanha, publicou o plano sobre os rejeitos radioativos da indústria nuclear naquele país, no qual demonstra a situação da gerência do CNQ e dos rejeitos de atividade alta, e qual a estratégia adotada para o futuro com relação à armazenagem temporária do CNQ. Neste relatório constam: a gestão de rejeitos radioativos de atividade média e baixa; armazenagem temporária em curto e longo prazo; reprocessamento e gestão final do CNQ, dos rejeitos de atividade alta; interrupção das atividades das usinas; comunicações sociais; planos de pesquisa e desenvolvimento; e, o panorama mundial da gestão de rejeitos radioativos. Quanto à armazenagem temporária do CNQ, foram sugeridas soluções em duas fases: até o ano 2010, solucionar o problema com relação ao CNQ da central nuclear de Trillo; a construção de uma instalação de armazenagem seca temporária em longo prazo em cascos metálicos de duplo propósito no próprio sítio; e, a partir do ano 2010, abertura de uma instalação de armazenagem centralizada modular que receba tanto o CNQ como todos os rejeitos de atividade alta.

Em 1999, a IAEA publicou um levantamento feito em vários países sobre a armazenagem seca e úmida de combustível queimado. Essa publicação mostra o estado da arte de cada instalação e inclui dados sobre os sistemas de transportes. Após a reunião dos fatos a IAEA conclui que a melhor alternativa é que, após o resfriamento nas piscinas dos reatores, a armazenagem do CNQ seja feita em cascos em via seca.

Em documento publicado pela IAEA (1999a) foi descrito o grande aumento na quantidade de cascos para transporte e/ou armazenagem que serão necessários no futuro. Os cascos específicos para transporte, e aqueles específicos para armazenagem, chamados “cascos de propósito único” deverão ser descontaminados antes do transporte e armazenagem. Mesmo os cascos de duplo propósito, para transporte e armazenagem, devem ter suas superfícies externas descontaminadas antes desses procedimentos.

Quapp (1999) descreveu o conceito para a utilização do hexafluoreto de urânio empobrecido, reconvertido em óxido de urânio, para agregá-lo aos ingredientes tradicionais do concreto, de modo que a densidade fique maior que o concreto comum. Esse composto foi chamado de DUCRETE, acrônimo de D.U. (depleted uranium - urânio 
empobrecido) e concreto, sendo utilizado na fabricação de cascos de armazenagem especiais.

A USNRC (1999) publicou um regulamento que apresenta um método aceitável do cálculo das taxas de geração de calor para uso em projeto de instalações de armazenagem de CNQ. Esse método pode ser aplicado para o CNQ de reatores PWR ou BWR.

Em documento técnico, publicado em 2000, a IAEA abordou a tecnologia de armazenagem do CNQ em recipientes (contêineres) de propósitos múltiplos. Os cascos, quanto a sua finalidade, podem ser divididos em:

- simples, que desempenham uma única função na gerência do CNQ, por exemplo, transporte ou armazenagem;

- múltiplos, ou multi-propósito, que cumprem mais que uma função, por exemplo, transporte, armazenagem e deposição. Os cascos multi-propósito, têm, ainda, como requisitos: mobilidade, capacidade de recuperação do CNQ, modularidade, redução no processo de transferência de CNQ, facilidade no descomissionamento, aceitação do público e, como resultado, uma economia maior.

O mesmo documento técnico (IAEA, 2000) ainda apresentou vários cascos multi-propósito existentes no mundo como o GNS CASTOR alemão, Holtec Hi-Storm americano, NAC STC e UMS americanos, Transnuclear NUHOMS ${ }^{\circledR}$ e TN68 americanos, Transnucléaire TN24 francês, e BNFL Transtor e Weflex americanos.

A CNEN (2000) revisou a norma NN-1.16, que determina os requisitos a serem adotados para o estabelecimento e implementação de sistemas de garantia da qualidade em instalações nucleares e determina a forma com que devem ser preparados os programas de garantia da qualidade que deverão ser submetidos à CNEN para licenciamento.

O laboratório de Los Alamos, nos EUA publicou um artigo técnico no qual foram relatados os acidentes com criticalidade ocorridos até o ano 2000.

Maiorino et al. (2000) relataram a experiência no envio dos 127 elementos CNQ em cascos metálicos de transporte, do reator IEA-R1 localizado no IPEN, São Paulo, para os Estados Unidos.

Ryhänen (2000) discutiu os procedimentos para determinar um local para a construção de uma instalação para gerência de rejeitos radioativos na Finlândia. Um dos itens é que no planejamento inicial exista a avaliação da opinião pública e que ela seja 
favorável, e isso, afirmou o autor, é difícil conseguir para uma instalação de armazenagem de CNQ, por exemplo.

Fairlie (2000), em relatório dirigido ao Greenpeace, estabeleceu uma comparação entre o reprocessamento do combustível nuclear queimado e a armazenagem seca do mesmo sem o reprocessamento. $\mathrm{O}$ autor assegurou que para esta última alternativa o impacto ao meio ambiente seria bem menor e apresentou um estudo de avaliação econômica de produção de cascos para CNQ, bem como mostrou os custos envolvidos para alguns tipos de cascos desenvolvidos.

A empresa americana Fluent (2001), mediante código de computador do mesmo nome, realizou estudos de aquecimento do CNQ armazenados em piscina, caso ocorresse acidente com perda de toda a água de resfriamento. Os resultados obtidos no estudo foram que, para os CNQ com mais de quatro anos de resfriamento, só com o resfriamento pelo ar a temperatura do CNQ não passaria de $600^{\circ} \mathrm{C}$.

Lamarsh e Baratta (2001) publicaram um livro para utilização em cursos de engenharia nuclear. Dentre os vários capítulos podem ser destacados o de física atômica e nuclear, interação da radiação com a matéria, difusão de nêutrons e moderação, remoção de calor de reatores nucleares, proteção contra radiação e blindagem da radiação.

Na Lei ordinária 10.308, de 20 de novembro de 2001, foram estabelecidas normas para o destino final dos rejeitos radioativos produzidos em território nacional, incluindo a seleção de locais, a construção, o licenciamento, a operação, a fiscalização, os custos, a indenização, a responsabilidade civil e as garantias referentes aos depósitos radioativos.

Andersson e Andrews (2001), em relatório técnico da SKB (Svensk Kärnbränslehantering $A B$, Suécia), abordaram o desenvolvimento de técnicas avançadas de soldagem, seja durante a fabricação de cascos de armazenagem de rejeitos nucleares para a selagem dos mesmos. Os cascos considerados pelos autores eram de cobre com $50 \mathrm{~mm}$ de espessura e suportes internos também metálicos. O objetivo do estudo foi viabilizar a deposição de CNQ em repositórios durante milhares de anos (cerca de 100.000 anos), pois o cobre seria bem resistente à corrosão. Entre as novas técnicas os autores relatam a soldagem por meio da fusão do cobre com feixes de elétrons ou calor de fricção.

Bunn et al. (2001), em relatório sobre a armazenagem temporária de CNQ preparado para as Universidades de Harvard (EUA) e Tóquio (Japão), apresentaram os tipos de armazenagem existentes nesses e alguns outros países. Referiram também sobre os custos da armazenagem e da construção de instalações temporárias. A armazenagem 
temporária de CNQ é crucial para o futuro da energia nuclear, como descreveram os autores, por causa do impacto gerado pela gerência do combustível queimado em controvérsias políticas, perigos ambientais, riscos com relação à proliferação e custos econômicos. Os dois países em foco no relatório possuíam visões antagônicas com relação ao CNQ: o Japão o considerou uma fonte valiosa de urânio e plutônio para aplicação na fabricação de combustível, e os Estados Unidos o consideraram como rejeito porque os custos de um novo tratamento seriam muito elevados e o reprocessamento permitiria a extração do plutônio, o que criaria riscos desnecessários quanto à proliferação de armas nucleares.

Hirsch e Neumann (2001) relataram o grande impacto quando são abordadas as conseqüências provenientes de um ataque terrorista ou guerra, com relação aos cascos de transporte e armazenagem temporária de CNQ. No relatório citaram ataques com munição perfurante, colisão de um veículo de transporte de combustível nuclear, queda de um avião comercial na instalação de armazenagem temporária e até mesmo bombardeio aéreo sobre a instalação. As informações constantes neste relatório podem ser aproveitadas para traçar o plano de segurança para os locais de armazenagem propostos em qualquer país.

Marsh e Stanford (2001) escreveram que por causa das dificuldades de ataque a uma central nuclear, os terroristas não as vêem como alvos atrativos. No caso de outras instalações nucleares, como a chance de liberação radioativa perigosa é remota, também não são de interesse de terroristas.

Em documento publicado em 2001, a IAEA apresentou o perfil do ciclo do combustível nuclear de vários países, entre eles o Brasil. Nesse perfil a IAEA explana a gerencia do CNQ.

A CNEN (2002) revisou a norma NE-1.04 que regula o processo licenciamento de instalações nucleares. Esta norma se aplica às atividades relacionadas com a localização, construção e operação de instalações nucleares, abrangendo suas diversas etapas.

Forsberg e Haire (2002) referiram sobre cascos multi-propósito construídos com materiais compostos por aço e urânio empobrecido. Afirmaram que esse sistema poderia melhorar a segurança e garantias de salvaguardas com baixos custos.

Lidskog e Andersson (2002), em relatório para a Associação Internacional para Disposição Ambientalmente Segura de Materiais Radioativos, descreveram como as autoridades responsáveis de dez países realizam a gerenciam de rejeitos radioativos. Entre 
os países descritos, encontra-se uma descrição interessante sobre o sistema de gerência de CNQ na Alemanha.

Marcelli e Smith (2002), em artigo publicado em revista especializada, abordaram sobre a instalação de armazenagem de CNQ situada na Ucrânia e o casco de concreto para armazenar CNQ desenvolvido por eles, indicado para o CNQ dos seis reatores nucleares existentes num mesmo sítio.

Pennington e Mcgough (2002), após os eventos ocorridos nos EUA em 11 de setembro de 2001, quando dois aviões comerciais colidiram com os dois edifícios do World Trade Center em New York, discutiram a segurança dos cascos de concreto para armazenagem de CNQ caso sofressem o impacto de uma aeronave comercial de grande envergadura. Para o estudo foi considerada a armazenagem seca em cascos de concreto multi-propósito modelo NAC. Quanto a esta abordagem teórica, não foi considerada a liberação de radionuclídeos na atmosfera nem exposição dos elementos armazenados ao meio-ambiente.

Em relatório técnico sobre a pesquisa e recomendações para a armazenagem de CNQ, a IAEA (2002) analisou a armazenagem temporária em longo prazo. As observações foram divulgadas por grupos de discussões e no contexto foram levados em conta quatro temas: 1. armazenagem do CNQ em longo prazo; 2. comportamento do sistema de armazenagem seca em longo prazo; 3. instalações de armazenagem úmida; e, 4. legislações pertinentes à armazenagem. Os tópicos mais importantes do relatório foram dedicados à discussão e previsão da integridade e recuperação do CNQ.

Earle (2002), ao considerar um combustível nuclear queimado genérico, fez uma análise de custos comparando diferentes tipos de armazenagem: úmida, seca em cascos duplo propósito, seca em cascos só para armazenagem, silos e poços. Nesta análise o custo de diversos tipos de armazenagem foi comparado com a armazenagem em cascos duplo propósito. O autor sugeriu que o local para armazenagem seja o mais próximo do local de geração do CNQ para reduzir os custos de transporte e minimizar a quantidade de cascos necessários para esta finalidade. O autor afirmou ainda que a estocagem de CNQ em instalações de armazenagem seca são tecnologicamente mais seguras e econômicas, como já o demonstraram as instalações estabelecidas nos EUA, Japão e Austrália.

Maiorino et al. (2002) apresentaram o progresso do Projeto Técnico Cooperativo para a América Latina, cujo objetivo é definir a estratégia regional para gerenciar o CNQ de reatores de pesquisa. 
Vossnacke et al. (2003) citaram a experiência referente à gerência do combustível armazenado em cascos metálicos e de concreto na Alemanha, denominados CASTOR e CONSTOR respectivamente. Os cascos CASTOR foram desenvolvidos na década de 1970 e são utilizados em 19 instalações de armazenagem de CNQ e proporcionam um confinamento seguro e apropriado. Os cascos CONSTOR tiveram seu desenvolvimento iniciado em meados de 1990, construídos com materiais mais comuns de forma a baratear o custo final do produto, sem prejudicar os requisitos de transporte e segurança que são observados para os cascos metálicos. Até 2002, tinham sido construídos 30 cascos CONSTOR e armazenados com sucesso.

Shah et al. (2003) examinaram a integridade estrutural de um casco Hi-Storm utilizando o método de análise por elementos finitos, por meio do programa de computador ANSYS. Os autores fizeram um modelo detalhado do piso e do casco incluindo o casco externo de concreto, o cilindro multi-propósito e o cesto de combustível. Os resultados da análise foram avaliados e concluiu-se que o casco Hi-Storm tem uma margem significante de segurança.

Thompson (2003) realizou um trabalho sobre segurança nacional e relatou que as pessoas e o ambiente estavam diante de um risco muito grande quanto a ataques terroristas cujos alvos seriam as piscinas de armazenagem de CNQ. Esse ataque hipotético poderia causar a perda da água da piscina, aumento da temperatura do CNQ ali guardado, com conseqüente incêndio e liberação de material radioativo na atmosfera. Apesar de mais seguro em armazenagem seca a céu aberto do que em armazenagem úmida, o CNQ também poderia sucumbir a um ataque terrorista. Por isso, o autor propôs instalações de armazenagem seca mais “robustas”, ou seja, capazes de resistir a ataques terroristas.

A IAEA foi responsável por várias conferências que servem como material de apoio para reunir informações sobre a armazenagem de combustível queimado. Os Anais da Conferência Internacional sobre Armazenagem de Combustível Queimado, realizada em Viena, em 2003, contém muitos relatórios interessantes. Entre eles podem ser citados:

- Ahmed et al. (2003) apresentaram a situação do combustível queimado gerado no Paquistão e o método de armazenagem considerado o mais adequado para aquele país. A opção escolhida foi a da armazenagem seca em silos de concreto, mas ainda avaliaram dois modos diferentes de transferência do combustível da piscina para a instalação:

a) individualmente, em tambores de aço para 11 ou 36 elementos, e que seriam carregados na piscina; 
b) reunidos e fechados em uma célula blindada especial e soldada.

- Hanson e Chollet (2003) dissertaram sobre a experiência obtida na armazenagem do combustível queimado em módulos de concreto horizontais. Este sistema, conhecido como $\mathrm{NUHOMS}^{\circledR}$, foi instalado nos EUA, Armênia e encomendado pela Ucrânia. Os módulos acondicionam o CNQ de reatores tipo PWR, BWR, RBMK e VVER.

- Biro e Rodna (2003) apresentaram a estratégia adotada pela Romênia com relação ao combustível queimado. A central nuclear de Cernavoda iniciou suas operações, em 1996, e produziu 100ton de CNQ originado no Reator 1, e o Reator 2, CANDU 6, que entrou em operação em maio de 2007. A Romênia escolheu como solução a armazenagem seca do CNQ, em módulos de concreto produzidos por uma empresa canadense.

- Khan e King (2003) expuseram um estudo de caso sobre o processo de licenciamento de uma instalação de armazenagem seca de CNQ no Canadá. O processo de licenciamento foi iniciado, em 1996, com uma carta de intenções e a aprovação foi decidida em 2000. O primeiro edifício para armazenagem de CNQ da instalação se tornou operacional em 2003. O trabalho dos autores deu uma noção do tempo necessário para que uma instalação de armazenagem temporária no Brasil possa tornar-se operacional, visto que o processo de licenciamento relatado é similar ao exigido pela CNEN.

- Kulkarni et al. (2003) realizaram um trabalho no qual informaram como o CNQ é gerenciado nas instalações indianas. A armazenagem úmida é predominante na Índia, nos diversos reatores e nas plantas de reprocessamento. Os autores citaram que foi necessário aumentar ou construir novas instalações de armazenagem, em razão da diferença de tempo existente entre a geração do CNQ pelos reatores e seu reprocessamento. Dentre as três instalações de armazenagem em construção, fora dos sítios dos reatores, uma é seca e o CNQ permanece em cascos de concreto, e as outras são piscinas fora da instalação da central.

- Coufal e Brzobohatý (2003) relataram a situação do CNQ na República Checa e os tipos de instalações de armazenagem temporária em longo prazo, construídas ou planejadas naquele país. Em 2002, o governo checo adotou o conceito de armazenagem seca de CNQ cujas instalações seriam localizadas nos sítios das centrais nucleares, e uma instalação subterrânea de apoio também por via seca. Esta última foi demonstrada em um projeto para a armazenagem de cascos que seriam transportados por via férrea para túneis subterrâneos horizontais intercomunicados.

- Lietava et al. (2003), também da República Checa, apresentaram especificamente a situação da gerência do CNQ na instalação de Dukovany, que foi 
comissionada em 1997. Esta instalação constava inicialmente de um edifício com um saguão de armazenagem seca de CNQ em cascos metálicos com capacidade de 600ton. Com o passar do tempo foi necessário aumentar a capacidade de armazenagem da instalação e foi iniciada a construção de outro edifício com capacidade para 1300ton. O relatório concluiu, ainda, que a instalação existente era segura e nunca ocorreram eventos anormais.

- Takats e Buday (2003) apresentaram a situação do CNQ na Hungria, que possui na central de Paks, quatro reatores nucleares. Após um processo de seleção, do qual participaram sete empresas que apresentaram tecnologias de armazenagem diferentes, foi escolhido o sistema de armazenagem seca em poços. A instalação foi comissionada em 1997.

- Verdier et al. (2003) apresentaram a experiência suíça de armazenagem temporária em curto prazo e transporte de cascos. A Suíça adotou duas formas diferentes de gerenciar o CNQ: enviá-lo para as instalações de reprocessamento em La Hague, França, e Sellafield, Inglaterra, e também armazená-lo em uma instalação seca, centralizada, denominada ZWILAG, no próprio território Suíço. Na França, o CNQ suíço era armazenado na própria instalação de reprocessamento antes de ser reprocessado. Na Inglaterra, o CNQ era colocado em cascos metálicos especiais tipo multi-propósito que eram enviados para a instalação úmida (piscina centralizada) e lá permaneciam dentro dos cascos até o reprocessamento.

Roland et al. (2003) apresentou exemplos desenvolvidos pela empresa AREVA para armazenagem seca de CNQ, entre elas instalações em poços na França e Holanda, cascos modelo TN24 de duplo propósito e o sistema NUHOMS ${ }^{\circledR}$.

Romanato e Rzyski (2003) apresentaram um levantamento dos aspectos ambientais provenientes do transporte de combustível nuclear queimado fora dos limites de um reator. Nesse levantamento, incluíram a sistemática de transporte, desde a retirada do CNQ do reator até a chegada à instalação de armazenagem temporária. Essas informações fizeram parte de um dos tópicos do programa de armazenagem de CNQ em locais além das fronteiras da instalação do reator do qual o CNQ é retirado.

Em 2003, a IAEA publicou documento que abordava pesquisa sobre o comportamento das instalações de armazenagem de CNQ, e relatava a experiência de vários países que possuem reatores nucleares comerciais. No tocante à armazenagem úmida, o relatório abordou: a corrosão dos revestimentos de zircônio, do aço inoxidável e 
das ligas de magnésio; a indicação da melhor forma de controle químico da água das piscinas; o tratamento físico; controle da temperatura; e interação com os materiais utilizados no revestimento e cestos de armazenagem. Quanto à armazenagem seca, o relatório citou processos de secagem do CNQ e a experiência de vários países que contam com esse tipo de armazenagem. Ainda foram discutidos os problemas que podem ocorrer nas instalações de armazenagem de CNQ, as tecnologias e as técnicas de monitoração.

Forsberg (2003) abordou os então recentes desenvolvimentos na construção de cascos multi-funcionais com materiais compostos: sobre-casco de armazenagem e sobrecasco para transporte, bem como casco de transferência. O casco do tipo cermet de dióxido de urânio é disperso em uma matriz de aço, também usado em um tipo de cerâmica utilizada em blindagens militares que aumentam a resistência do armamento militar e em ferramentas de corte.

Martinez e Gago (2003) discutiram o programa nuclear espanhol e a política de rejeitos na Espanha. A Espanha possui um programa de armazenagem seca em cascos de duplo propósito. Os autores apresentaram as características do casco utilizado e da instalação de armazenagem para esses cascos.

Em endereço eletrônico, a World Health Organization (2003) mantém uma página com dados sobre o urânio exaurido. Nela, além das explicações sobre o que é este material, informa também onde pode ser aplicado e o que pode acontecer a uma indivíduo no caso de exposição ou ingestão.

Em 2004, um relatório mais extenso feito pelo Office of Civilian Radioactive Waste Management, sobre o programa suíço de gerência de rejeitos radioativos, mostrou que a Suíça guarda o CNQ e os rejeitos de atividade alta e média, de todo o seu território, na instalação de armazenagem seca de ZWILAG, situada ao norte do país. O documento citou também, que a experiência quanto ao transporte do CNQ é muito grande, visto que desde 1970 o mesmo é realizado, com a utilização de vários modelos de cascos de aço, para as instalações de reprocessamento na França e no Reino Unido. Em 2009, o acesso a esse documento ficou restringido a apenas um resumo.

Cumo et al. (2004) escreveram um livro que abrange todos os aspectos relacionados ao encerramento no ciclo de vida de reatores nucleares e instalações do ciclo do combustível nuclear. Uma atenção especial foi dada à tarefa de descomissionamento de um reator nuclear, pois esta é uma tarefa complexa, de longo prazo e altamente tecnológica e ainda que não possa ser comparada com a construção de instalações, apresenta similaridades como segurança, licenciamento, análise estrutural, entre outras. O capítulo 
sobre a gerência do combustível queimado abordou, como uma das soluções imediatas no decorrer do descomissionamento, a armazenagem provisória seca.

O Departamento de Energia americano (DOE) publicou, em 2004, um relatório sobre o Programa Nacional de Combustível Nuclear Queimado (NSNFP) discutindo as responsabilidades técnicas e o licenciamento para o repositório de Yucca Mountain (EUA). As atividades deste programa abordadas no relatório foram: a integração do projeto e suas interfaces, desenvolvimento de um casco para CNQ, análise do repositório e a aceitação do local, dos rejeitos, e o transporte final.

Kawakami et al. (2004) relataram que duas empresas japonesas desenvolveram um casco para transporte e armazenagem de CNQ. Esse casco possuía duas características diferentes dos outros tipos de casco: uma era um sistema de fechamento com três tampas ao invés de duas e a outra, a utilização de uma solução aquosa como blindagem contra nêutrons. O casco teria um bom sistema de troca de calor, fabricação rápida e um custo competitivo.

Soares e Silva (2004) explanaram que dos quatro reatores de pesquisa existentes no Brasil, em três não existiam problemas quanto à armazenagem de CNQ. O único reator que merecia atenção quanto ao CNQ é o IEA-R1. O trabalho descreveu os combustíveis utilizados nos reatores e apresentou como é feita a armazenagem do CNQ.

A ABNT (2005) publicou a norma ISO 14004 (2005) revisada, que estabeleceu requisitos para implantação de um sistema de gestão ambiental, proporcionou subsídios para identificar aspectos potenciais e impactos ambientais, e elaborar um programa de redução desses impactos, por meio de controles, metas e monitoramento contínuo.

A norma NN-3.01 revisada pela CNEN, em 2005, estabeleceu os requisitos básicos de proteção radiológica das pessoas quanto à exposição à radiação ionizante. Essa norma se aplica ao manuseio, transporte, armazenagem e deposição de materiais radioativos; em situações de emergência e exposições crônicas. Ainda, é compulsória a utilização dessa norma desde a escolha do local até o descomissionamento da instalação. A monitoração ambiental está contemplada nessa norma mediante as posições regulatórias 3.01/008 - Programa de monitoração radiológica ambiental e 3.01/009 - Modelo para elaboração de programa de relatório de monitoração radiológica ambiental, e a Resolução 09/69 Normas para escolha de locais de reatores de potência.

Em documento emitido em 2005, a IAEA considerou que na década de 1950 ocorreu o início da tecnologia remota para aplicações nucleares e o desenvolvimento de manipuladores. Com o passar dos anos e com a introdução de sistemas sofisticados, hoje 
existem, para certas tarefas no parque nuclear, mecanismos manipuladores robotizados guiados por câmeras e guindastes especiais.

A IAEA (2005a) emitiu um regulamento visando à proteção de indivíduos, propriedade e ambiente dos efeitos da radiação durante o transporte de material radioativo. Ele se aplica a qualquer modalidade de transporte e para as fases de projeto, fabricação, manutenção e reparo de cascos de transporte de CNQ.

Roshan et al. (2005), em trabalho realizado para o Governo da Índia, apresentaram fatores importantes que afetam a seleção de locais para instalações nucleares. O mais importante é que devem ser levados em conta os perigos radiológicos potenciais contra os indivíduos que trabalham na instalação, o público e o meio ambiente. O processo de seleção do local da instalação envolve dois estágios básicos, pesquisa de um local e avaliação do local.

Ikonen, em relatório escrito para a Posiva Oy, em 2005, apresentou o intervalo adequado de temperaturas de um repositório para CNQ armazenado em cascos. Apresentou, ainda, a temperatura máxima a ser considerada ao se projetar um casco para CNQ, comentando os métodos de cálculo numéricos e analíticos envolvidos.

Lee et al. (2005) fizeram uma análise térmica do casco para estocagem de 24 elementos de CNQ de reator PWR com burnup de 55.000MW/tU e resfriamento de seis anos para poder predizer os valores máximos de temperatura dos cascos de concreto e do próprio combustível em condições normais de armazenagem, condições anormais e acidentes. Assumiram como temperatura ambiente normal $27^{\circ} \mathrm{C}$ e $40^{\circ} \mathrm{C}$ para situações anormais. Neste último caso, aventaram a hipótese de bloqueio parcial da ventilação na instalação de armazenagem e nos casos de acidentes o bloqueio total. O calor de decaimento dos 24 elementos considerado foi de 25,2 kW. A análise térmica do sistema de ventilação da instalação de armazenagem também foi efetuada pelos autores para determinar o tamanho e a forma do duto de ventilação. Para tanto usaram o código computacional FLUENT de elementos finitos para análise dinâmica de fluidos. Os resultados mostraram que as temperaturas máximas dos elementos do CNQ e do casco de concreto eram mais baixas que aquelas permitidas nas três condições consideradas.

Luz e Baltar (2005) discorreram sobre um componente importante para a confecção do concreto pesado, a barita, e fornecem dados técnicos do mineral relatando a considerável capacidade em absorção de raios gama. Neste caso a barita é utilizada na fabricação de cimentos para instalações de armazenagem de material radioativo e como agregado em concretos especiais para a fabricação de cascos de concreto para CNQ. 
Göhring et al. (2005) discorreram sobre a futura construção de uma instalação de armazenagem do CNQ da central de Ignalina na Lituânia. Os elementos CNQ estavam armazenados em poços e serão carregados em cascos, e armazenados na nova instalação. Neste caso específico, os cascos seriam de concreto, para combustível de reator tipo RBMK.

McCombie (2005) abordou a armazenagem de rejeito radioativo na Europa e como pode ser determinado um local para a construção de uma instalação nuclear. Citou a literatura internacional na qual observou que os autores procuraram estabelecer um procedimento para decidir sobre quais critérios poderiam ser utilizados para definir a localização de uma instalação nuclear.

Em 2005, Romanato fez uma análise da armazenagem temporária de CNQ, comparando o método úmido ao seco. Mostrou que na armazenagem úmida o elemento CNQ permanece submerso por um longo tempo, os cestos com o combustível podem ser rearranjados, ou o elemento CNQ pode ser desmontado e as varetas colocadas em uma caixa metálica, e ser novamente colocado na piscina, ou ainda, pode ser inserido em cascos e armazenado na piscina. A armazenagem seca consiste da retirada do elemento CNQ da piscina, inserção em cilindros ou cascos e depósito em instalações construídas para mantêlo isolado do meio ambiente. Esses cilindros podem ser enterrados, ou colocados em tubos na chamada armazenagem em poços, ou em silos de armazenagem na vertical ou na horizontal, ou até mesmo inseridos em cascos. Os cascos de concreto, ou metálicos, podem ser armazenados em instalações a céu aberto ou fechadas.

Romanato e Rzyski (2005) realizaram um estudo sobre a avaliação de eventuais acidentes que podem ocorrer durante o transporte do CNQ, desde a retirada da piscina de resfriamento até a chegada na instalação de armazenagem.

Silva et al. (2005) analisaram as opções de armazenagem temporária de CNQ de reatores de pesquisa. Os resultados dessa análise foram utilizados para propor uma opção para a armazenagem temporária de CNQ do reator IEA-R1 do IPEN.

Shapovalov et al. (2006) abordaram o desenvolvimento de uma nova geração de cascos de transporte e armazenagem de CNQ. O casco de material composto pode ser utilizado para armazenar combustível de reatores PWR e possui uma resistência maior contra acidentes e ataques terroristas. No relatório, o casco foi descrito de forma básica, e os autores descreveram estudos de projeto, sistema térmico, segurança nuclear e resistência a ataques. Apresentaram também os requisitos necessários e os resultados alcançados. 
Em 2006, a IAEA consolidou a Convenção Conjunta sobre Segurança na Gerência de CNQ, Segurança na Gerência de Rejeitos Radioativos e estabeleceu vários requisitos a respeito de como:

(1) assegurar que a criticalidade não seja atingida e que a remoção do calor residual gerado durante a gerência do CNQ seja realizada adequadamente;

(2) assegurar que a geração de rejeitos radioativos associados ao CNQ seja mantida no mínimo possível;

(3) proporcionar efetiva proteção aos indivíduos que trabalham na instalação, ao público e ao meio-ambiente, aplicando métodos de proteção, em nível nacional e aprovados por órgãos de regulação;

(4) levar em consideração os perigos biológicos, químicos e outros que possam ser associados à gerência do CNQ.

Para as instalações de armazenagem de CNQ, deverão ser avaliados todos os fatores relacionados à segurança dos locais, durante toda a vida da instalação, incluindo o impacto de segurança relativo aos trabalhadores, o público e o meio-ambiente. Ainda convencionou que cada país deve tomar medidas, inclusive com cooperação internacional, de modo que se mantenha um alto nível de segurança quanto a gerência do CNQ. Alertou que deve existir, também, preocupação com os perigos potenciais aos indivíduos em todos os estágios dessa gerência de modo a evitar acidentes ou mitigar suas consequências radiológicas.

Um documento técnico emitido pela IAEA (2006a) identifica os passos importantes na identificação dos tópicos de gerência de CNQ, incluindo os requisitos para análise de segurança. Também indica a necessidade da descrição desses tópicos com relação aos parâmetros específicos no banco de dados.

O endereço eletrônico do Integrated Nuclear Fuel Cycle Information System (2008), pertencente à IAEA, permite o acesso a um banco de dados com informações que facilitam o desenvolvimento de atividades de planejamento relacionadas à área nuclear.

Em relatório público, emitido em 2006, pelo National Research Council dos EUA, o Comitê de Segurança de armazenagem de combustível nuclear queimado de origem comercial abordou os aspectos de segurança necessários em uma instalação de armazenagem temporária de CNQ. Neste documento estão incluídos ataques terroristas contra uma instalação do tipo citado, avaliação dos riscos potenciais das instalações de armazenagem úmida e seca, e as vantagens da armazenagem seca com relação à úmida. 
Romanato e Rzyski (2006) estudaram as desvantagens do sistema de armazenagem úmida quanto à redundância dos sistemas elétricos e de resfriamento, e a manutenção do nível de água dentro de limites especificados, de modo que a temperatura do CNQ armazenado não aumente e se mantenha no valor recomendado.

Em 2006, Halstead e Dilger abordaram a necessidade de fazer testes em cascos para CNQ (queda livre, penetração, estanqueidade, etc.) para fins de licenciamento desses cascos com vistas ao transporte e armazenagem. Analisaram seus custos e verificaram que os custos dos testes são pequenos (1\%) em relação aos custos totais de transporte.

O relatório apresentado por Matveev et al. (2006) refere sobre um conjunto de armazenagem e transporte de CNQ, com segurança avançada. Esse conjunto envolve a utilização de urânio empobrecido (DU) metálico que possibilita um melhor desempenho na blindagem de raios gama e é destinado ao transporte e armazenagem de CNQ de reatores VVER russos e de reatores de grafite. Para a Rússia, a utilização de urânio empobrecido é de grande valia, pois irá resolver o problema de acúmulo deste material. O urânio empobrecido é um rejeito do processo de enriquecimento de urânio para combustíveis. A utilização do DU na fabricação de cascos é uma solução para a redução do estoque e evita potenciais aspectos e impactos ao meio ambiente.

Hayashi et al. (2006) estudaram materiais hidrogenados como o hidroborato de magnésio e hidreto de titânio para blindagem de nêutrons na forma de pós e na forma sólida, embora tenham concluído que o polietileno na forma sólida seja ainda o produto mais comum, mais aplicado e mais barato existente no mercado.

A IAEA (2007) publicou um trabalho que apresenta as opções para a gerência do CNQ, os requisitos globais para a armazenagem e transporte, os aspectos de operação e manutenção e a experiência de países que já fazem armazenagem de CNQ. Abrange, também, as tecnologias existentes para os cascos de CNQ e os requisitos necessários para os sistemas de armazenagem.

Na coletânea de trabalhos apresentados nos anais na Conferência Internacional sobre Gerência de CNQ originados de Reatores de Potência (PWR) que ocorreu em 2006, foram publicado pela IAEA, em 2007, encontram-se alguns dados importantes a serem considerados no presente estudo (IAEA, 2007a):

- Amaral et al. comentaram que a armazenagem temporária de CNQ é cada vez maior, especialmente a armazenagem seca em várias formas como poços, silos e cascos.

- Shirai et al, do CRIEPI, Japão, estudaram um programa sobre armazenagem seca e propuseram a primeira instalação de armazenagem provisória de CNQ com início 
de operação em 2010. Os cascos a serem armazenados seriam de concreto e para preparação dos requisitos de segurança e desenvolvimento de procedimentos para licenciamento, o CRIEPI continua estudando a degradação dos materiais componentes dos cascos e possibilidade de vazamento pela tampa do casco durante acidentes de transporte e de manuseio após armazenagem.

- Tanaka, membro da OECD, descreveu os aspectos políticos, estratégicos e técnicos associados com o CNQ e sua gerência, em particular, aspectos da armazenagem em longo prazo. Afirmou que o custo da gerência do CNQ é de 1-5\% do custo da geração de energia no parque nuclear. A armazenagem em longo prazo e com duração superior a 100 anos pode exigir a reformulação dos aspectos de gerência originais porque este aspecto não se baseia apenas nos aspectos técnicos, mas aspectos sociais associados com a manutenção e segurança.

- Gregoric alertou que ataques terroristas já ocorridos na Europa, em locais com grande concentração de público como estações de metrô ou de trem, podem acontecer em instalações nucleares ou durante o transporte de material nuclear. A ameaça do terrorismo nuclear é real. Na área de combustível irradiado, vários estudos estão em curso para avaliar as consequências e a vulnerabilidade do CNQ. O autor citou que a segurança é responsabilidade do estado, porém no caso nuclear os países deveriam trabalhar em conjunto o que já vem acontecendo desde 2005 quando 119 países assinaram um documento referente a essa segurança contra os atos terroristas ou criminais.

- Os cientistas armênios Solinac et al. descreveram o sucesso da aplicação do sistema NUHOMS ${ }^{\circledR}$ não só para combustível nuclear queimado originado em reatores PWR, mas aquele originário dos reatores VVER-440PWR existentes na Armênia. Neste sistema o CNQ é confinado em recipiente com atmosfera inerte e este, por sua vez, colocado em casco de concreto. O calor de decaimento é removido por ventilação por sistema de convecção natural passiva. O sistema NUHOMS ${ }^{\circledR}$ é uma instalação passiva que permite blindar e conter com segurança o CNQ, de modo que acidentes e fenômenos naturais não interfiram em sua integridade. A armazenagem dos cascos de concreto, na Armênia, é feita em silos de concreto, na posição horizontal.

- Baggett e Brach, da NRC, discutiram a experiência quanto à regulamentação de instalações para armazenagem seca de CNQ e seu licenciamento e inspeção. O órgão americano regula as instalações onde são manipulados materiais radiativos e combustíveis nucleares para garantir a proteção adequada da saúde e segurança públicas, promover a defesa e segurança e, proteger o meio ambiente. Neste caso, o combustível irradiado pode 
ser provisoriamente armazenado em instalações regulamentadas, licenciadas, inspecionadas e com revisão técnica.

- Lietava citou a análise estrutural de cascos por meio do código de computador ANSYS nos casos de testes de contenção de CNQ em cascos CASTOR 440/84M quanto aos testes de resistência em queda de 1m e 9m para a configuração da estocagem. Os acidentes considerados neste caso envolvem: explosão de gás; terremoto; impacto de casco deslocado contra outro casco na instalação de armazenagem; queda de 0,3m como resultado de acidente que envolva a manipulação do casco; e, impacto por queda de pequenas aeronaves sobre o casco.

- Goll et al., preocupados com as instalações de armazenagem seca de CNQ na Alemanha e Estados Unidos, refletiram sobre os conceitos atuais que podem ser ultrapassados rapidamente por causa dos limites usuais de burnup do combustível, que já têm sido atingidos e até ultrapassados. A implicação no transporte e armazenagem do CNQ, nesse caso, foi discutida. Os autores concluiram que a armazenagem seca possui um papel muito importante hoje em dia e que a segurança tem se mostrado adequada em diversos países que adotam esta prática. Quanto à novas restrições para a qualificação mecânica dos cascos para CNQ com burnup mais alto que o praticado atualmente, os autores acharam que não seriam necessárias. Novas pesquisas devem envolver parâmetros que verifiquem a tensão de ruptura sob condições de tensão baixa. Os autores mencionaram que a oxidação do combustível continua sendo um desafio. A forma de transferência do CNQ para o casco obedece a procedimentos bastante rigorosos, mas existe pouca base técnica para a determinação se a transferência pode ser flexibilizada ou se deve ser mais controlada.

- Issard referiu que a melhoria das características do combustível nuclear durante a sua fabricação, associadas ao melhor desempenho dos reatores, resultem em combustível altamente enriquecido burnups mais elevados com altas cargas de calor e altos níveis de radiação, e exigem a utilização de novos materiais em instalações de armazenagem de CNQ em cascos. O estudo desenvolvido por Issard abrangeu a melhoria das tecnologias na fabricação dos cestos que acomodam os CNQ dentro dos cascos, inovações na transferência de calor, novos materiais para blindagem de nêutrons e, melhoria do desempenho dos materiais absorvedores de choques. O autor sugeriu planejamento diferente do que os aplicados hoje em dia para os cestos, para o sistema de convecção natural e materiais para a blindagem de nêutrons. 
Em 2007, a CNEN emitiu seu quarto Relatório apresentado na Convenção sobre Segurança Nuclear em Viena, Áustria, que teve como objetivo descrever o programa nuclear brasileiro, as instalações nucleares e as medidas tomadas para atingir os objetivos da Convenção. Abrangeu as usinas de Angra 1, Angra 2 e informou que Angra 3 estava em processo de licenciamento. Com relação à armazenagem de CNQ, informou que aquele gerado em Angra 1 continuaria armazenado na piscina até o fim da vida útil operacional do reator. O CNQ de Angra 2 necessitaria, em pouco tempo, espaço adicional de armazenagem seca ou úmida, pois a piscina tem capacidade para apenas 15 anos de operação do reator.

A ASME (2007) disponibiliza, em seu portal eletrônico, informações e códigos e entre eles está a série Boiler and Pressure Vessel Code que estabelece regras de segurança relativas a projeto, fabricação e inspeção de vasos de pressão e componentes nucleares. Esse documento pode ser utilizado para a elaboração de projeto destinado à construção de um casco para armazenagem de CNQ.

Romanato e Rzyski (2007) abordaram os aspectos técnicos e físicos de segurança que uma instalação de armazenagem de CNQ necessita possuir. Concluíram que a melhor forma de impedir ou, ao menos, reduzir ataques por terra ou sabotagens é a utilização de barreiras como paredes de concreto armado, trincheiras, etc.

Romanato e Rzyski (2007a) compararam a armazenagem úmida e seca, e concluíram que, em longo prazo, a segunda é mais vantajosa que a primeira. Quanto à corrosão do CNQ em armazenagem em poços, silos, cascos metálicos e cascos de concreto a mesma torna-se praticamente inexistente.

A USNRC (2007) referiu que as piscinas de CNQ de centrais nucleares estão ficando cheias e que em certas centrais os combustíveis mais velhos estão sendo retirados, colocados em cascos e armazenados em instalações de armazenagem seca. Dada a crescente tendência quanto à armazenagem seca, foi necessário avaliar se existe risco para o público e identificar os itens que contribuem de modo dominante para esses riscos nas operações de retirada do reator, transporte e armazenagem do CNQ. Por esta razão, a Nuclear Regulatory Commission (USNRC), o Office of Nuclear Regulatory Research (ONRR), desenvolveram uma metodologia para fazer uma avaliação probabilística do risco (APR) inicial de um sistema de armazenagem seca em cascos. Assim, o ONRR e o Serviço de Segurança e Salvaguardas de Material Nuclear da USNRC realizaram de forma conjunta um estudo de avaliação e documentaram seus resultados em relatório. 
Em endereço eletrônico, a USNRC (2007a, 2007b) discorreu sobre como é uma armazenagem úmida de CNQ em piscinas, discute a armazenagem seca e forneceu um glossário de termos utilizados em processos de armazenagem de CNQ.

A terceira revisão do relatório emitido pela CNEN, publicado em 2008, para a Convenção Conjunta sobre Segurança na Gerência de Combustível Nuclear Usado e Segurança na Gerência de Rejeitos Radioativos, informou novamente que se for tomada a decisão de armazenar o CNQ em via seca, a CNEN deverá estabelecer requisitos detalhados a respeito.

Frajndlich (2008) relatou o envio realizado, em 1999, do CNQ americano usado do reator de pesquisas IEA-R1, IPEN, para os Estados Unidos. O autor citou o sucesso das operações de carregamento, movimentação e transporte para o porto de Santos - SP, de 127 elementos CNQ que permaneceu no IPEN durante 40 anos, que ocorreram sem nenhum incidente, como previsto nos planos de segurança e transporte.

No endereço eletrônico do Ministério de Ciência e Tecnologia (2008) foi noticiado o envio de casco com CNQ do reator IEA-R1. Esse seria o segundo transporte de CNQ do Brasil para os Estados Unidos.

Romanato (2008) descreveu os testes em protótipos de cascos para CNQ de reatores de pesquisa, realizados no CDTN/CNEN-MG, como observador. Os testes foram feitos em protótipo resultante de um projeto entre o CDTN e pesquisadores da Argentina e Chile, tendo a IAEA como financiadora e colaboradora. Esses mesmos testes poderão ser aplicados ao protótipo de casco nacional para CNQ-PWR antes de sua homologação.

A central nuclear da Ucrânia, Zaporizhzhya Nuclear Power Plant, divulgou em seu endereço eletrônico (www.npp.zp.ua/snfs/description, 2008), informações sobre a armazenagem de rejeitos radioativos. A armazenagem do CNQ é do tipo seco em cascos de concreto. No site são apresentadas as dimensões dos cascos utilizados, o esquema da instalação de armazenagem e o veículo utilizado para a movimentação de cascos. Os dados referentes à central nuclear da Ucrânia permitiram desenvolver a idéia de utilizar um veículo para a movimentação dos cascos dentro da instalação de armazenagem estudada no presente trabalho.

A empresa americana John Caunt Scientific (2008) apresentou sua linha de produtos para blindagem da radiação nuclear. A empresa produz material para ser utilizado em blindagem de chumbo contra raios gama, e para blindagem contra nêutrons com material fabricado em polietileno. 
A empresa americana NAC (2008) forneceu informações interessantes sobre seus produtos desenvolvidos para transporte e armazenagem de CNQ. Neste aspecto a NAC mostra os cascos de concreto, tipo MPC e UMS.

O Centro de Energia de Indian Point (2008) informou que, como outras centrais nucleares, sua piscina chegou a uma capacidade de armazenagem quase completa e que começariam a utilizar instalações independentes de armazenagem de CNQ ou armazenagem seca em cascos. Descreveu superficialmente um casco e quais os aspectos principais quanto à resistência do casco.

O IBAMA (2009), órgão brasileiro do Ministério do Meio Ambiente, estabeleceu todo o procedimento de obtenção do licenciamento ambiental. O licenciamento ambiental é, no Brasil, uma obrigação legal anterior à instalação de qualquer empreendimento ou atividade potencialmente poluidora ou degradadora do meio ambiente e possui como uma de suas principais características a participação social na tomada de decisão por meio de realizações de audiências públicas.

A INB - Indústrias Nucleares Brasileiras (2009) disponibilizou em seu endereço eletrônico informações sobre o urânio e o combustível nuclear produzido a partir do mesmo. Os elementos combustíveis de Angra 1 e 2 são, atualmente, fabricados por eles.

O Centro de Pesquisas Meteorológicas e Climáticas Aplicadas a Agricultura, CEPAGRI publicou, em 2009, um estudo sobre a velocidade dos ventos no território brasileiro e a sua classificação. Estes dados são importantes para o desenvolvimento do projeto de construção da instalação de armazenagem de cascos com CNQ no Brasil.

A Universidade Nacional de Brasília descreveu em seu site (2009) os fenômenos naturais que podem influenciar a erosão de materiais, como os ventos e a água.

O Observatório Sismológico (2009) mantém endereço eletrônico que informa sobre a atividade sismológica no Brasil e evidencia todos os terremotos que ocorreram no território nacional e aqueles de magnitude maior que cinco graus na escala Richter que ocorreram no mundo.

Metalprices (2009) é um portal eletrônico que mostra o valor financeiro dos metais nas bolsas de valores em todo mundo. A cotação dos metais é diária e serviu para a realização do cálculo de custos dos materiais utilizados na confecção dos cascos de armazenagem para CNQ-PWR no Brasil, propostos no presente trabalho.

O endereço eletrônico da central nuclear de Yankee Rowe (2009) dos Estados Unidos mantém uma página que discorreu sobre a armazenagem de combustível nuclear queimado, porque a mesma possuía uma instalação em Massachusetts que foi fechada. Os 
cascos para CNQ desta instalação estão armazenados em instalação seca ao ar livre em cascos metálicos recobertos com casco de concreto.

No regulamento da USNRC (2009) foram estabelecidos os requisitos para embalagem, preparação para envio e transporte de materiais nucleares, bem como procedimentos e normas para aprovação de embalados e para o transporte de materiais físseis.

Outro regulamento da USNRC (2009a) estabeleceu os requisitos, procedimentos e critérios para emissão de licenças de recebimento, transferência e posse de CNQ de reatores de potência associados a uma instalação independente de armazenagem de CNQ.

No endereço eletrônico da Dow Química (DOW, 2009) podem ser encontradas características técnicas de vários tipos de polietileno de alta densidade que podem ser estudados na utilização como blindagem contra nêutrons.

Os códigos e softwares para computador utilizados para diversos cálculos relacionados com o presente trabalho são citados a seguir:

- ANSYS - software de análise de estruturas através do método dos elementos finitos que permite a resolução de problemas mecânicos, análise estrutural linear, não linear, estática e dinâmica, transferência de calor, problemas de fluidos, acústica e eletromagnéticos (ANSYS, 2009);

- APOLLO - código para cálculo das seções de choque dos isótopos e cálculo de blindagens;

- AUTOCAD - software que permite a elaboração de desenhos técnicos em 2D e 3D (AUTODESK, 2010);

- CAPSIZE - código que permite determinar o número máximo de elementos combustíveis queimados que podem ser armazenados em diversos tipos de cascos (ORNL, 2009);

- FLUENT - software que permite a modelagem de fluxo de fluidos (FLUENT, 2001);

- HELIOS - código para avaliar as seções de choque macroscópicas dos elementos combustíveis;

- LABFIT - software para análise, tratamento de dados experimentais e ajuste de curvas (LABFIT, 2009); 
- NASTRAN - software de análise de estruturas desenvolvido pela NASA, similar ao ANSYS (MSC, 2009);

- ORIGEN - código para cálculo do acúmulo, decaimento e processamento de materiais radioativos (ANL, 2009);

- REBUS-3 - código de depleção para o ciclo do combustível (ANL, 2009);

- RCT - código de pós-processamento que depende dos cálculos realizados pelo REBUS-3 (ANL, 2009);

- SCALE - software para se efetuar cálculos nas áreas de física de reatores, segurança à criticalidade, blindagem contra radiações e caracterização de combustível nuclear queimado, para instalações nucleares e projetos de embalagens de transporte ou armazenagem (ORNL, 2009a). 
3 CASCOS, ARMAZENAGEM E TRANSPORTE 


\section{CASCOS, ARMAZENAGEM E TRANSPORTE}

Este tópico versa sobre a caracterização do combustível nuclear de reatores de potência, o detalhamento dos cascos de armazenagem quanto a sua função, características e modelos existentes, bem como informações sobre as instalações de armazenagem existentes ao redor do mundo e a forma de transporte.

\subsection{Caracterização do combustível nuclear}

O combustível nuclear compõe-se de um núcleo formado por compostos de urânio, tório ou plutônio revestimento e estrutura física final. O combustível mundialmente mais utilizado em reatores de água leve e água pesada é o dióxido de urânio $\left(\mathrm{UO}_{2}\right)$, na forma de ligas metálicas, cerâmica ou dispersões.

Após a queima em um reator, o combustível passa a ser denominado combustível nuclear queimado (CNQ) e apresenta uma grande variedade de elementos radioativos como produtos de fissão (PF), transurânicos (TRU), actinídeos e os produtos de ativação. No processo de físsão do ${ }^{235} \mathrm{U}$, o núcleo fisssionado por nêutrons térmicos pode ser dividido em mais de 40 formas diferentes que resultam em 80 produtos de fissão primários (fragmentos de fissão) (Glasstone e Sesonske, 1975).

As características do CNQ dependem das condições iniciais do combustível (geometria, enriquecimento, etc.), irradiação (permanência no núcleo do reator, burnup, etc.) e tempo de armazenagem temporária após ter sido retirado do reator. Os dados podem ser obtidos por meio de cálculos em função dos registros de fabricação do combustível e permanência no reator. Esses cálculos têm sido feitos com auxílio de códigos específicos (ORIGEN - Oak Ridge Isotope Generation, ORNL, EUA; APOLLO, França; HELIOS, Suécia) que consideram as características dos radionuclídeos utilizados em cada tipo de reator e do burnup do combustível queimado. Hoje em dia, o código ORIGEN da ORNL foi atualizado e é denominado ORIGEN-RA. É usado para fazer cálculos detalhados sobre a transmutação dos radionuclídeos baseada no fluxo de nêutrons calculado por outros programas de computador, como REBUS-3 e RCT. O código é usado para estimar as características da emissão da radiação e o decaimento dos constituintes do combustível irradiado (ANL, 2009).

Na Figura 6 são apresentados os números de massa dos produtos de fissão térmica do ${ }^{235} \mathrm{U}$ e de fissão rápida do ${ }^{238} \mathrm{U}$, na proporção de fissões nucleares que produzem um 
determinado número de massa, ou seja, rendimentos de fissão (Glasstone e Sesonske, 1975).

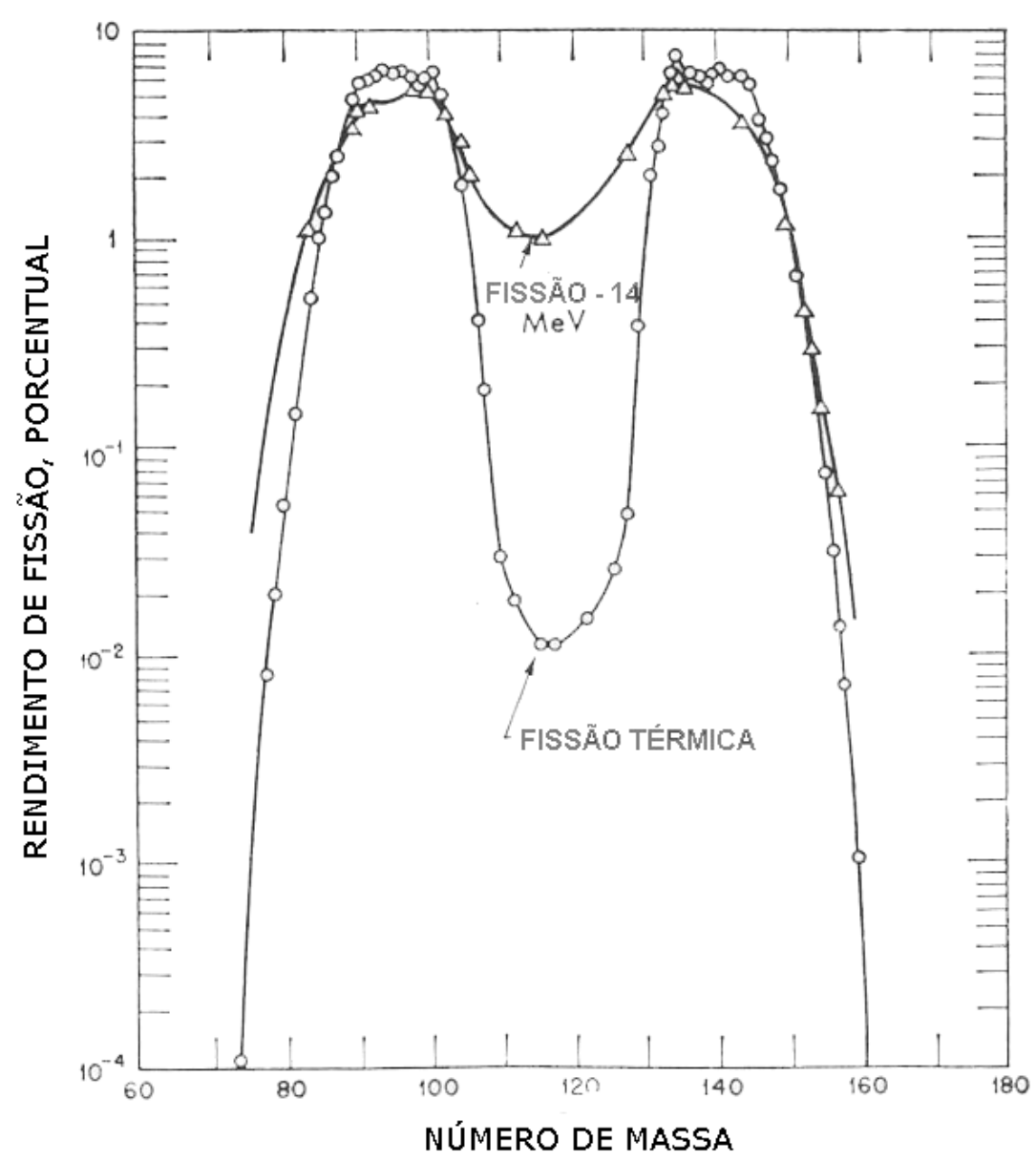

Figura 6 - Rendimento de fissão do ${ }^{235} \mathrm{U}$ e ${ }^{238} \mathrm{U}$ em função do número de massa Fonte: Adaptado de Glasstone e Sesonske (1975)

O inventário de radionuclídeos no CNQ relaciona-se com o decaimento dos produtos de fissão, actinídeos e, principalmente, os transurânicos e os produtos de ativação.

Os produtos de fissão equivalem a $3 \%$ da massa do combustível original. A maioria é composta por radioisótopos de meia-vida curta, mas existe um número considerável de radioisótopos de meia-vida média e longa. Podem ser citados os isótopos seguintes:

Meia-vida média:

- ${ }^{155} \mathrm{Eu},{ }^{154} \mathrm{Eu},{ }^{85} \mathrm{Kr}$ e o ${ }^{113 \mathrm{~m}} \mathrm{Cd}$ - até 15 anos;

$-{ }^{90} \mathrm{Sr}$ e ${ }^{137} \mathrm{Cs}$ - ao redor de 30 anos;

- ${ }^{121 \mathrm{~m}} \mathrm{Sn}$ e ${ }^{151} \mathrm{Sm}$ - até 100 anos.

Meia-vida longa:

$-{ }^{99} \mathrm{Tc},{ }^{126} \mathrm{Sn}$ e ${ }^{79} \mathrm{Se}$ - entre 200 e 300 mil anos; 
$-{ }^{93} \mathrm{Zr},{ }^{135} \mathrm{Cs},{ }^{107} \mathrm{Pd}$ e ${ }^{129} \mathrm{I}$ - milhões de anos e por esse motivo considerados “estáveis”.

Em 100 anos, a atividade dos nuclídeos com meias-vidas até cinco anos diminui por um fator $10^{6}$ e eles praticamente desaparecem. Na Figura 7 é mostrado o decaimento radioativo de elementos de atividade alta em uma tonelada e urânio de CNQ-PWR e na Tabela 1 é mostrado o decaimento da radioatividade ao longo do tempo.

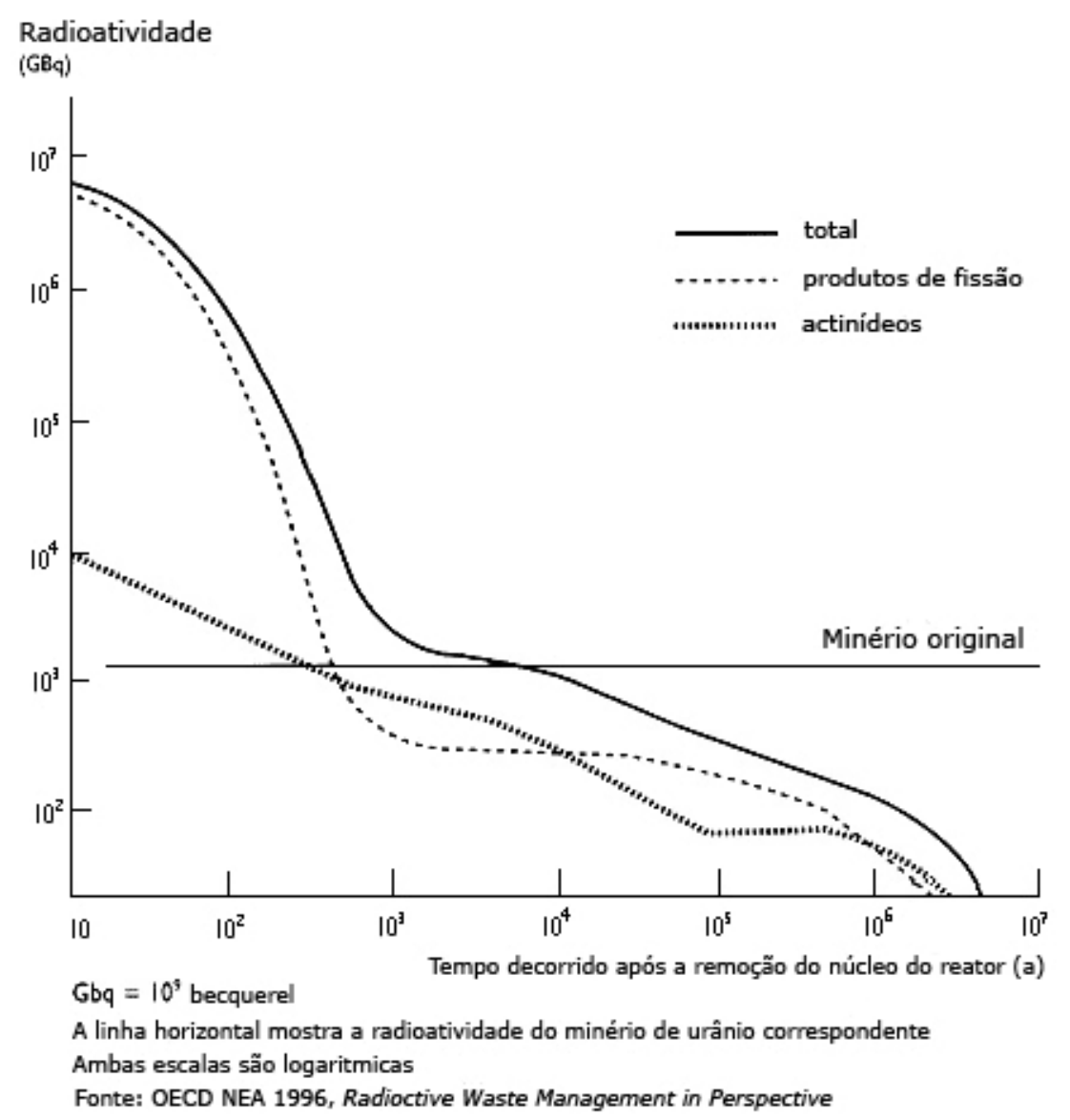

Figura 7 - Curva de decaimento de elementos radioativos em rejeitos de atividade alta Fonte: Adaptado de Freedom for Fission (2006)

Tabela 1 - Atividade relativa do CNQ em função do tempo decorrido após a retirada do núcleo do reator.

\begin{tabular}{cc}
\hline $\begin{array}{c}\text { Tempo decorrido após a retirada do CNQ do núcleo do reator } \\
\text { (anos) }\end{array}$ & Atividade relativa* $^{*}$ \\
\hline 0 & 1 \\
5 & $5 \times 10^{-3}$ \\
50 & $1 \times 10^{-3}$ \\
100 & $3,33 \times 10^{-4}$ \\
1000 & $1,33 \times 10^{-5}$ \\
\hline
\end{tabular}

* adimensional

Fonte: IAEA (2003) 
Para armazenar os cascos por tempo entre 20 e 150 anos, a radioatividade do CNQ a ser considerada é a dos produtos de fissão e entre eles devem ser consideradas as cadeias de decaimento do ${ }^{90} \mathrm{Sr} \rightarrow{ }^{90} \mathrm{Y}$ e do ${ }^{137} \mathrm{Cs} \rightarrow{ }^{137 \mathrm{~m}} \mathrm{Ba}$. Entre 200 e 500 anos os elementos transurânicos do CNQ como o ${ }^{241} \mathrm{Am}$ da cadeia de decaimento do ${ }^{241} \mathrm{Pu}$, tem meia-vida consideravelmente longa e decai por emissão alfa para o ${ }^{237} \mathrm{~Np}$. A do ${ }^{239} \mathrm{Pu}$, por exemplo, é de 24.000 anos e constitui $1 \%$ da massa do combustível original.

A emissão de gases nobres ( $\mathrm{Kr}$ e $\mathrm{Xe}$ ) é mais um fator a ser considerado. $\mathrm{O}$ ${ }^{85} \mathrm{Kr}$ tem uma meia-vida de 10,76 anos e o Xe de algumas horas, por este motivo o tempo de armazenagem mais longo não é problemático quanto à emissão desses gases para a atmosfera, após alguns anos de resfriamento em piscina. (Lamarsh e Baratta, 2001, IAEA TECDOC 1343, 2003).

Mesmo após ser retirado do núcleo do reator, o CNQ continua gerando calor, que diminui com o decaimento de radionuclídeos de meia-vida curta, conforme mostra a Figura 8. Nesta figura observa-se que, após um ano da retirada do CNQ do reator, o calor gerado é reduzido na ordem de 100 vezes e continua a diminuir ao longo do tempo. (National Research Council, 2006).

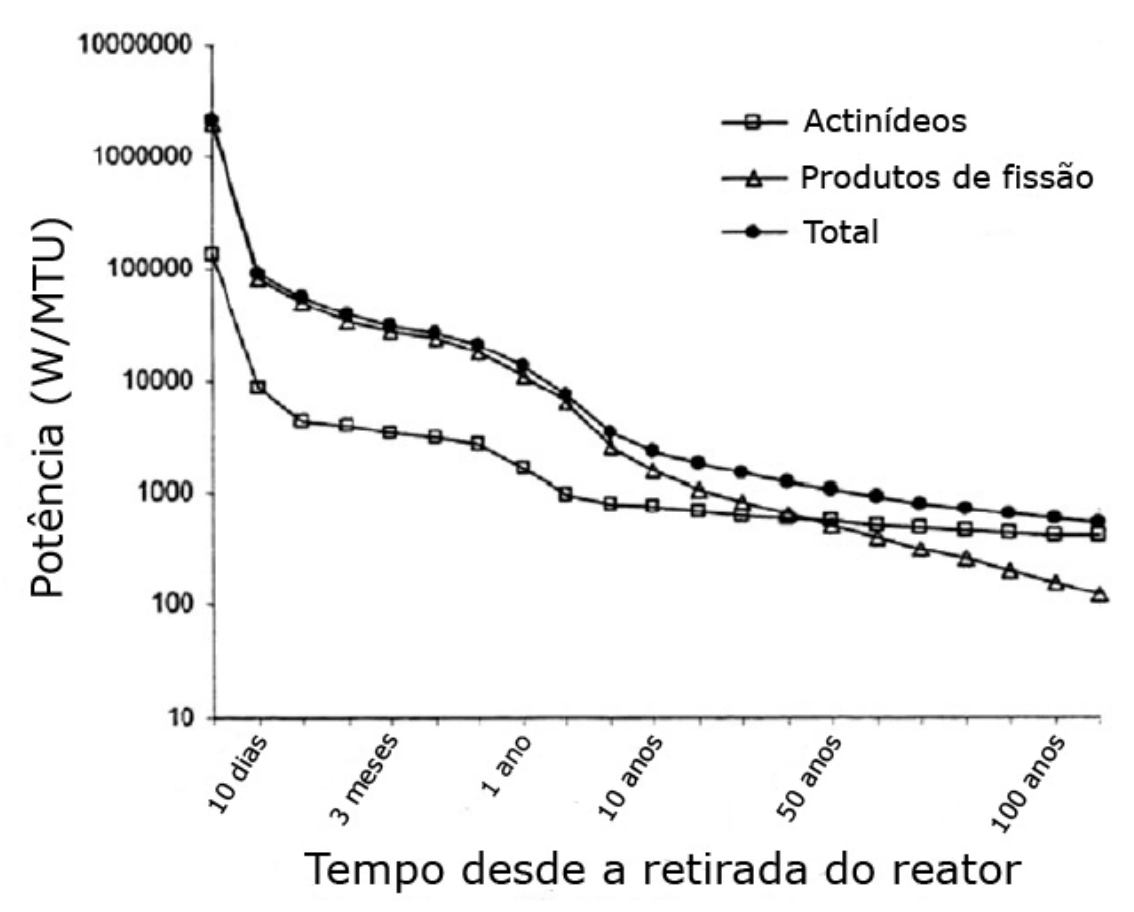

Figura 8 - Calor de decaimento do CNQ

Fonte: Adaptado de National Research Council (2006) 


\subsubsection{Combustível nuclear de Angra}

O combustível nuclear de reatores PWR, especificamente aquele usado nas usinas nucleares de Angra 1 e 2, foi caracterizado quanto à composição, enriquecimento, dimensões, taxa de queima (burnup) e tempo de queima.

Os combustíveis usados nos reatores Angra 1 e 2 possuem dimensões diferentes, mas são feitos do mesmo material estrutural. A Tabela 2 apresenta alguns detalhes dos combustíveis utilizados.

Tabela 2 - Características dos elementos combustíveis de Angra 1 e 2

\begin{tabular}{lcc}
\cline { 2 - 3 } & Angra 1 & Angra2 \\
\hline Número de elementos no reator & 121 & 193 \\
Número de varetas por elemento & 235 & 236 \\
Disposição das varetas no elemento & $16 \times 16$ & $16 \times 16$ \\
Comprimento efetivo da vareta & $3,65 \mathrm{~m}$ & $3,9 \mathrm{~m}$ \\
Diâmetro da vareta & $10 \mathrm{~mm}$ & $10,75 \mathrm{~mm}$ \\
Quantidade de pastilhas por vareta & 369 & 384 \\
Enriquecimento médio & $2,6 \%$ & $2,5 \%$ \\
Comprimento total do elemento & $4,058 \mathrm{~m}$ & $4,827 \mathrm{~m}$ \\
Massa do elemento & $600 \mathrm{~kg}$ & $832 \mathrm{~kg}$ \\
\hline
\end{tabular}

O revestimento do elemento combustível é feito de liga de zircônio conhecida como Zircaloy 4 (composição nominal: $\mathrm{Zr}$ - balanço, Sn - 1,2 a 1,7\%, Fe - 0.18 a 0,24\%, Cr - 0,07 a $0.13 \%)(A S T M, 1977)$.

O burnup dos combustíveis de Angra 1 e 2 é de 33 GWd/tU e o tempo de queima é de 12 a 18 meses.

A partir de 2008, são produzidos para Angra 2, elementos combustíveis enriquecidos a $4 \%{ }^{235} \mathrm{U}$ (NUCLEP, 2009). Esse novo combustível, com enriquecimento maior, implicará em recalcular as dimensões dos cascos de armazenagem propostos no presente trabalho.

A Figura 9 mostra um esquema do combustível tipo PWR . 


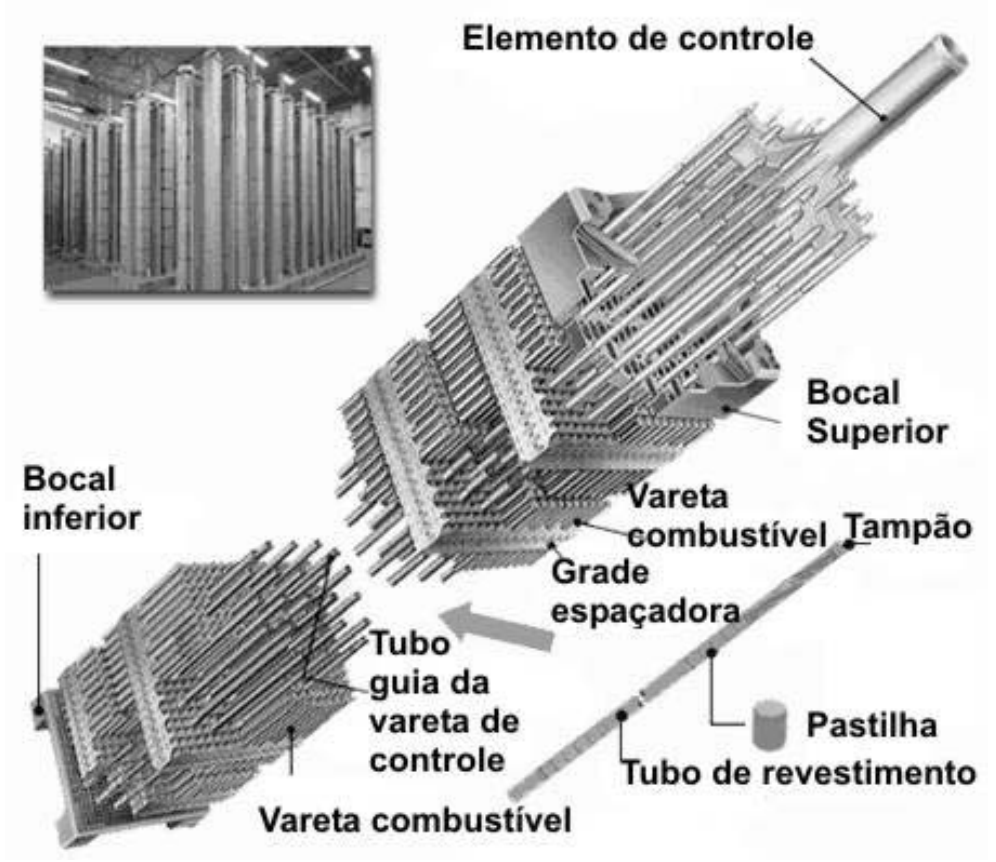

Figura 9 - Corte do elemento combustível de reator PWR com as varetas, elemento de controle, tubos guia e grade espaçadora.

Fonte: Adaptado de Mitsubishi Nuclear Fuel (2006)

\subsection{Estudo do casco para armazenagem}

No presente tópico são apresentadas as partes constituintes de um casco de armazenagem, quais são os modelos existentes no mundo, como é feito o transporte, além de como deve ser feita a identificação e rastreabilidade dos mesmos.

\subsubsection{Seleção do casco mais adequado}

A seleção do sistema de armazenagem (casco e instalação) envolve uma série de requisitos a começar pelo casco. A caracterização do casco, isto é, tipo de material de construção, dimensões, massa total e o projeto de fabricação é o ponto de partida para a sua concepção.

A primeira decisão a ser tomada, após uma primeira análise de custos, é se o material de construção do casco será de metal, concreto ou misturas especiais, e se será do tipo multi-propósito, ou casco só de transporte ou só de armazenagem. O custo mais baixo muitas vezes é o mais procurado, porém, a diferença entre um casco de transferência e um casco de metal ou concreto multi-propósito está na funcionalidade, custo que é diluído ao longo do tempo, e praticidade. 
A decisão quanto ao tipo de instalação de armazenagem, suas dimensões e modo de estocagem dos cascos, e o tipo de casco a ser ali depositado, deve ser tomada em conjunto. Um dos aspectos que hoje em dia são mais importantes para esta escolha é ajustar ambos de tal modo a evitar futura movimentação e transporte dos cascos, apesar das possíveis mudanças nas regulamentações futuras, pois o licenciamento dos cascos deve ser renovado de tempos em tempos em função do progresso que pode ocorrer nesta área (IAEA, 2006; Bagget e Brach, 2007).

A escolha de um casco só para armazenagem, ou multi-propósito, gera tomada de decisões diferentes, pois no segundo caso talvez o tempo de permanência do CNQ em piscinas de resfriamento possa ser menor, adequando o limite de burnup em função dos limites para o transporte de modo diferente que para um casco que sirva apenas para armazenagem. O casco multi-propósito é mais resistente ao longo do tempo quanto ao calor de decaimento e radiação emitidos pelo CNQ. A importância de combinar tipo de material e custos, atualmente é indiscutível. $\mathrm{O}$ aço normalmente é a primeira escolha e ela sempre recairá sobre materiais que proporcionem blindagem, boa transferência de calor, e resistência ao longo do tempo de armazenagem, dentro dos padrões de segurança.

Os cascos aqui considerados são destinados à armazenagem conhecida como seca. Este tipo de armazenagem é mundialmente utilizado desde 1970. Difere da armazenagem úmida porque como meio refrigerante é usado ar no lugar de água.

\subsubsection{Criticalidade do $C N Q$}

Os cascos, necessariamente, devem manter a criticalidade abaixo de um limite máximo, conhecido como subcriticalidade. Esse limite é representado pelo fator de multiplicação efetivo, $k_{e f f}$, definido como a razão entre a taxa de produção de nêutrons e a taxa de perda de nêutrons no sistema. Para que o sistema seja subcrítico (Duderstadt; Hamilton, 1976):

$$
k_{\text {eff }}<1
$$

De acordo com a IAEA (2007), um casco carregado com CNQ deve possuir o fator de multiplicação efetivo:

$$
k_{e f f}<0,95
$$

Uma vez dentro do casco, a subcriticalidade do CNQ é mantida mediante o grau de moderação entre o CNQ e moderadores, quantidade e distribuição de materiais 
absorvedores de nêutrons, geometria da distribuição dos elementos CNQ dentro do casco e efetividade dos refletores utilizados. (Duderstadt; Hamilton, 1976)

A título de ilustração, a Figura 10 apresenta um gráfico que indica os efeitos do conteúdo de boro disperso na superfície do cesto que abriga o CNQ no fator de multiplicação efetivo $k_{\text {eff. }}$ (Shappert et al., 1998)

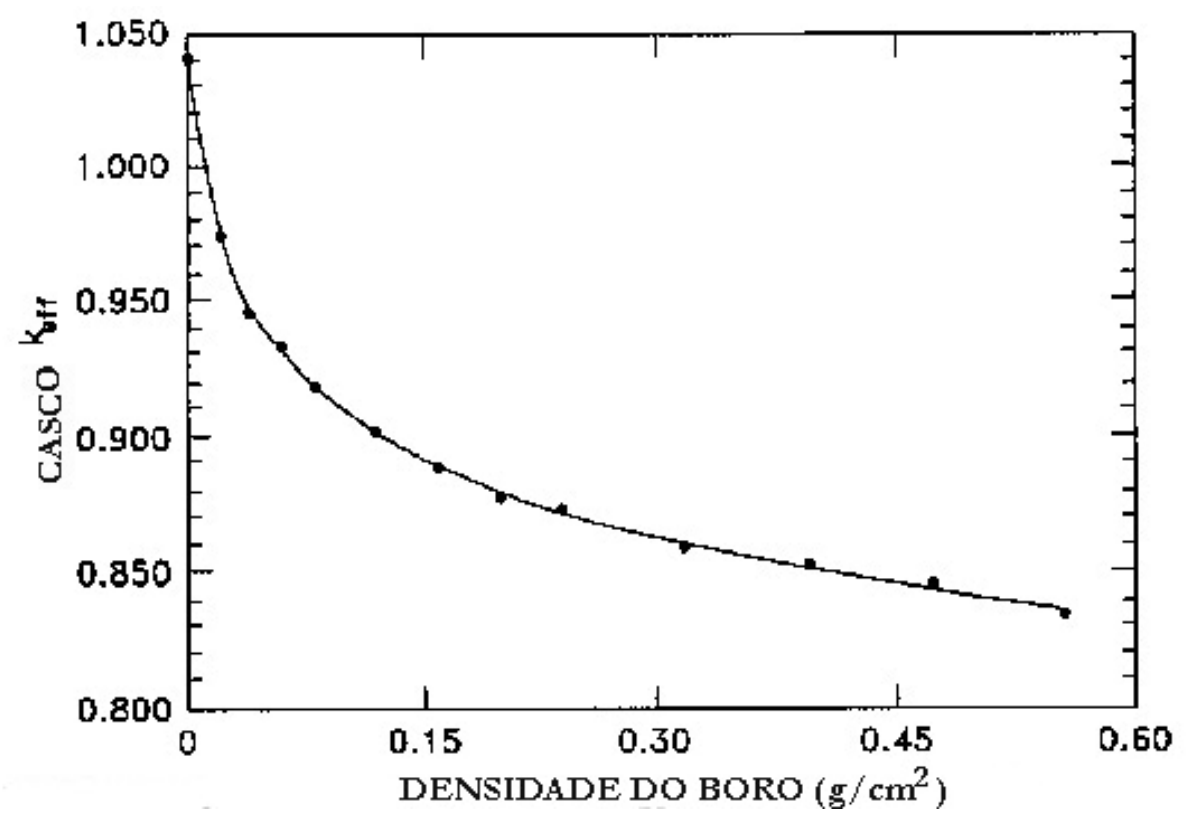

Figura 10 - Fator $k_{\text {eff }}$ em relação à densidade de boro disperso na superfície do cesto Fonte: Adaptado de Shappert et al.(1998)

\subsubsection{Calor de decaimento}

O calor irradiado no casco origina-se de duas fontes distintas. A primeira provém do decaimento dos radionuclídeos presentes no CNQ, como os produtos de fissão, e para burnup mais elevado e longos períodos considerados, os transurânicos também contribuem para o calor de decaimento. $\mathrm{O}$ cálculo do calor por decaimento é realizado por programas de computador validados, citados no Capítulo 2 (ORIGEN, APOLLO, HELIOS), e que permitem calcular o termo fonte (características radiológicas) apoiados nas condições iniciais do combustível (tipo de combustível e geometria, teor de elementos físseis, enriquecimento inicial, etc.), irradiação (tempo de residência no núcleo, etc.) e tempo de decaimento (idade), desde a descarga do reator. A segunda fonte de calor provém da parte externa do casco, dependendo das condições de armazenagem (insolação, temperatura ambiente, efeito de calor de cascos adjacentes, fogo e outras condições de acidentes que possam ser postuladas no projeto de concepção). 
De acordo com a IAEA (2006) a temperatura inicial externa do revestimento do próprio CNQ pode ser entre 300 e $400^{\circ} \mathrm{C}$, após certo tempo de decaimento, entre 200 e $300^{\circ} \mathrm{C}$, e em estocagem longa (5-10 anos) abaixo de $200^{\circ} \mathrm{C}$. Em função disto, o casco deve ser resistente ao longo do tempo de armazenagem para temperaturas que estejam abaixo dos limites estabelecidos. Por outro lado, em estudo feito para USNRC pela empresa FLUENT (2001) para prever as temperaturas que alcançaria um CNQ em piscina por mais de quatro anos em caso de acidente por perda total da água, usando um programa com o mesmo nome, chegaram à conclusão que no ar, o CNQ pode manter a temperatura abaixo de $600^{\circ} \mathrm{C}$. Em situações de acidente ou anormais o Nuclear Energy Agency (2005) determina que a temperatura do combustível não exceda $570^{\circ} \mathrm{C}$.

Na Tabela 3 é apresentado um exemplo de variação da potência térmica do CNQ retirado de um reator PWR de 1000MW(e) com um burnup máximo de $33 \mathrm{GWd} / \mathrm{tU}$.

Tabela 3 - Potência térmica do CNQ-PWR com burnup máximo de $33 \mathrm{GWd} / \mathrm{tU}$, após o desligamento do reator para descarga na piscina.

\begin{tabular}{ccc}
\hline $\begin{array}{c}\text { Tempo após } \\
\text { desligamento do reator }\end{array}$ & $\begin{array}{c}\text { Potência térmica } \\
(\mathbf{M W})\end{array}$ & $\begin{array}{c}\text { Potência térmica } \\
(\%)\end{array}$ \\
\hline 1 segundo & 500 & 17 \\
1 minuto & 150 & 5 \\
1 hora & 45 & 1,5 \\
1 dia & 15 & 0,5 \\
1 semana & 9 & 0,3 \\
1 mês & 4,5 & 0,15 \\
1 ano & 1 & 0,03 \\
10 anos & 0,1 & 0,003 \\
100 anos & 0,03 & 0,001 \\
1000 anos & 0,006 & 0,0002 \\
\hline
\end{tabular}

Fonte: IAEA (2003)

Estudos realizados pelo Department of Energy americano (DOE), referentes às temperaturas do casco de transporte, indicaram que a temperatura máxima nas paredes internas de aço inoxidável em nove cascos analisados foi de $316^{\circ} \mathrm{C}$. (DOE, 2004)

A temperatura na superfície externa de um casco deve ser limitada a $100^{\circ} \mathrm{C}$, contudo, é mais conveniente que o projeto seja feito de modo que a temperatura máxima na superfície do casco seja de $90^{\circ} \mathrm{C}$ para ter uma margem de segurança (Ikonen, 2005), ou um pouco mais baixa e não ultrapassar $85^{\circ} \mathrm{C}$ conforme sugere Shapovalov (2006). Lee et al. (2005) observaram que as temperaturas máximas no ambiente fechado onde se armazena 
CNQ-PWR, com burnup de $55 \mathrm{GW} / \mathrm{tU}$ e resfriamento de seis anos, em cascos de concreto não excedem $27^{0} \mathrm{C}$ em condições adequadas de ventilação.

\subsubsection{Sistema de resfriamento do casco com $C N Q$}

O sistema de resfriamento é do tipo passivo, que ocorre por convecção do ar e que não exige sistemas líquidos (água) ou dispositivos elétricos. Neste caso as manutenções periódicas do casco e as monitorações constantes do combustível são mais espaçadas e a confiabilidade em longo prazo é bem maior (Romanato; Rzyski, 2007a). No interior do casco, o CNQ é envolto por gás inerte, freqüentemente são usados hélio, argônio ou gás levemente reativo como o nitrogênio, que também evita a oxidação do combustível armazenado.

\subsubsection{Blindagem da radiação proveniente do $C N Q$}

Antes de ser encaminhado para armazenagem seca, o combustível deve ser guardado por 5 a 10 anos em piscinas com água para o decaimento inicial da atividade.

$\mathrm{Na}$ contenção física (cesto onde são colocados os elementos CNQ e o envoltório), o metal ou concreto serve como blindagem contra a radiação (nêutrons e a radiação gama) emitida pelo CNQ. Para blindar a radiação gama dos produtos de fissão, actinídeos, TRUs e produtos de ativação, podem ser usadas paredes espessas de ferro fundido, aço ou combinações de aço e chumbo ou urânio exaurido, e vários tipos de misturas (Forsberg, 2003; Göhring, 2005). As espessuras das paredes externas do casco podem variar entre $0,2 \mathrm{~m}$ e $0,7 \mathrm{~m}$.

A blindagem dos nêutrons é a mais difícil por causa de seu amplo espectro de energias, nêutrons térmicos $<0,5 \mathrm{eV}$; epitérmicos, de $0,5 \mathrm{eV}$ a $0,5 \mathrm{MeV}$; e rápidos $>0,5 \mathrm{MeV}$. Para blindar nêutrons rápidos, devem ser aplicados materiais altamente hidrogenados. Os nêutrons térmicos $(<0,5 \mathrm{eV})$ são absorvidos por materiais que contenham, por exemplo, boro estável.

A blindagem contra nêutrons geralmente pode ser feita com materiais que contenham boro, certos tipos de polímeros altamente hidrogenados, concreto comum e concreto denso. (Hondorp, 1984). Hoje em dia, são estudados diversos tipos de materiais altamente hidrogenados para blindagem de nêutrons rápidos como hidroborato de magnésio, $\mathrm{Mg}\left(\mathrm{BH}_{4}\right)_{2}$, o hidreto de titânio, $\mathrm{TiH}_{2}$, ou hidreto de zircônio, $\mathrm{ZrH}_{2}$ (Hayashi et al., 2006). O polietileno comum de alta densidade, na forma sólida, por enquanto é o 
produto mais acessível e barato no mercado nacional, mas que precisaria ser adaptado para fins do presente estudo.

\subsubsection{Carregamento dos cascos}

Para execução do carregamento, os cascos podem ser imersos na piscina na qual se encontram os elementos combustíveis queimados. Após a carga desses elementos e fechamento do casco, ele é içado e a água residual é drenada de seu interior. Alternativamente, o carregamento pode ser feito com o casco posicionado fora da piscina e o CNQ devidamente blindado para proteção radiológica do trabalhador é inserido no casco.

Para assegurar a evacuação total da água do interior do casco são utilizadas técnicas de secagem interna. Uma dessas técnicas é a secagem a vácuo, que envolve a diminuição da pressão interna do casco até abaixo da pressão de vapor da água, manutenção da pressão por um determinado tempo, para que o vapor condense e a água condensada resultante possa ser retirada. Outra técnica é a secagem por meio de gás aquecido a cerca de $150^{\circ} \mathrm{C}$ que promove a evaporação da água da superfície do elemento CNQ. A operação de secagem dura até que as massas de ar expelido e a do ar insuflado sejam iguais. (IAEA, 2003).

Após a secagem, os cascos são vedados e, por intermédio de uma válvula, é inserido gás inerte até uma pressão estabelecida. Os cascos são então transportados até a instalação de armazenagem, colocados sobre um piso de concreto que deve ter resistência suficiente para suportar a massa dos cascos.

\subsubsection{Mobilidade dos cascos}

Outra característica muito importante dos cascos é a mobilidade. O casco com CNQ pode ser deslocado para diferentes locais, isto é, para um depósito temporário ou para o local de reprocessamento. Assim sendo, os cascos podem ser classificados em cascos de simples propósito, duplo propósito ou multi-propósito.

- Simples propósito é utilizado para transporte. Tem a criticalidade controlada, blindagem e outros requisitos de segurança para o casco e o cesto;

- Duplo propósito é utilizado para transporte e armazenagem provisória, e além da criticalidade controlada e blindagem, ainda proporcionam proteção do CNQ e possuem dispositivos para a remoção do calor residual;

- Multi-propósito é utilizado para transporte, armazenagem e ainda, destinados à disposição final do CNQ. Nenhum casco desse tipo foi licenciado até a 
presente data. Não existe um repositório final em operação e muitos desconsideram essa denominação, qualificando-os como cascos de duplo propósito melhorados (National Research Council, 2006)

Na Figura 11 são apresentados os propósitos funcionais dos cascos na etapa final do ciclo do combustível nuclear (IAEA, 2007).

Durante todo o tempo em que os cascos permanecem em armazenagem seca, devem manter a funcionalidade de seus elementos estruturais, estanqueidade, estabilidade nas camadas de proteção, eficácia do moderador de nêutrons, qualidade da solda utilizada na confecção dos cestos de armazenagem de modo que sejam evitados vazamentos, a subcriticalidade do sistema e, as propriedades de blindagem das radiações emanadas pelo CNQ. Devem resistir, também, aos efeitos causados pelas intempéries, caso fiquem sem proteção física (chuva, granizo, neve, ventos, umidade e variações de temperatura), mediante a utilização de materiais estruturais e acabamento externo (p.ex. pintura) apropriados. O projeto do casco deve possibilitar a realização de reparos nos eventuais desgastes potenciais detectados ao longo do tempo.

\section{Sistema de transferência e transporte}

\begin{tabular}{|c|c|c|c|c|}
\hline PROPÓSITO & NO REATOR & LONGEDO REATOR & \multicolumn{2}{|c|}{ DISPOSIÇĂOO } \\
\hline SIMPLES & $\begin{array}{l}\text { Camegamento } \\
\text { do CNO }\end{array}$ & $\begin{array}{l}\text { Casco de } \\
\text { Armazenagem }\end{array}$ & \multicolumn{2}{|c|}{$\begin{array}{c}\text { Invólucro } \\
\text { de Diposição }\end{array}$} \\
\hline DUPLO & $\begin{array}{l}\text { Carregamento } \\
\text { do CNO }\end{array}$ & $\begin{array}{l}\text { Casco de } \\
\text { Armazenagem } \\
\text { e Transpate }\end{array}$ & \multicolumn{2}{|c|}{$\begin{array}{c}\text { Invólucro } \\
\text { de Disposiçã̃o }\end{array}$} \\
\hline $\begin{array}{l}\text { MULTI } \\
\text { (TRIPLO) }\end{array}$ & $\begin{array}{l}\text { Carregarnento } \\
\text { do CNO }\end{array}$ & \multicolumn{2}{|c|}{$\begin{array}{c}\text { Casco de Armazenagem, Transporte } \\
\text { e Disposiçã̃o }\end{array}$} & \\
\hline
\end{tabular}

Figura 11 - Propósitos funcionais dos cascos quanto ao sistema de transferência e transporte

Fonte: Adaptado de IAEA (2007). 


\subsubsection{Descrição do casco}

\subsubsection{Partes principais de um casco metálico}

Genericamente, pode-se dizer que qualquer casco de armazenagem tem como partes principais corpo do casco, que pode ser de parede simples ou composta, cestos para o CNQ, tampas de fechamento, munhões externos de elevação e translação, válvulas e drenos, cobertura de válvulas que atravessem a contenção, limitadores de impacto (no caso de transporte) e estruturas de apoio.

As propriedades físicas dos materiais utilizados para a fabricação de um casco devem ser avaliadas para operar em regime elástico ou moderadamente plástico e, apesar de que grandes deformações que possam alterar os parâmetros geométricos da estrutura, o material do casco deve ser suficientemente dúctil de modo que não ocorram fraturas. Normalmente, para fabricar cascos metálicos, utilizam-se aços inoxidáveis ou aços ferríticos. Materiais que se tornam frágeis à baixa temperatura são inaceitáveis.

- Corpo do casco

Comumente o casco de armazenagem tem um formato cilíndrico com diâmetro acima de $1,5 \mathrm{~m}$, contém uma câmara central que abriga um conjunto de cestos (IAEA, 2003; 2007), construídos de forma a receber os elementos CNQ que, para reatores PWR, são feixes de seção quadrada. Um esquema deste tipo de casco é apresentado na Figura 12.

Existem cascos de formatos prismáticos, como os produzidos no Canadá para CNQ do tipo CANDU, não abordados nesta tese (Figura 13).

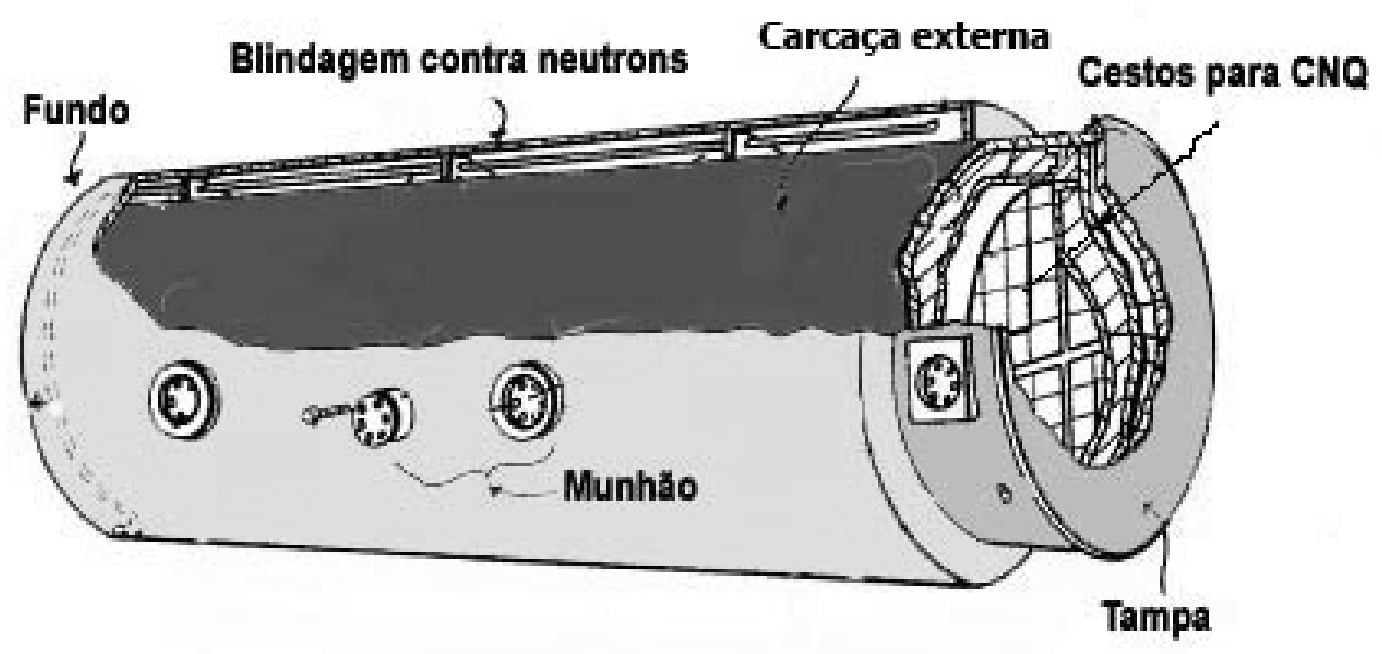

Figura 12 - Casco de armazenagem de CNQ Fonte: Adaptado de Lusk; Ridihalgh (1987) 
Os cascos possuem uma das extremidades constantemente fechada, conhecida como fundo e, a extremidade oposta, por onde é introduzido o CNQ, uma tampa removível. O casco possui blindagem contra nêutrons e radiação gama.

O casco pode ser adaptado para armazenagem na posição horizontal (Hanson; Chollet, 2003), ou vertical apoiado sobre uma superfície horizontal, como mostrado na Figura 14.

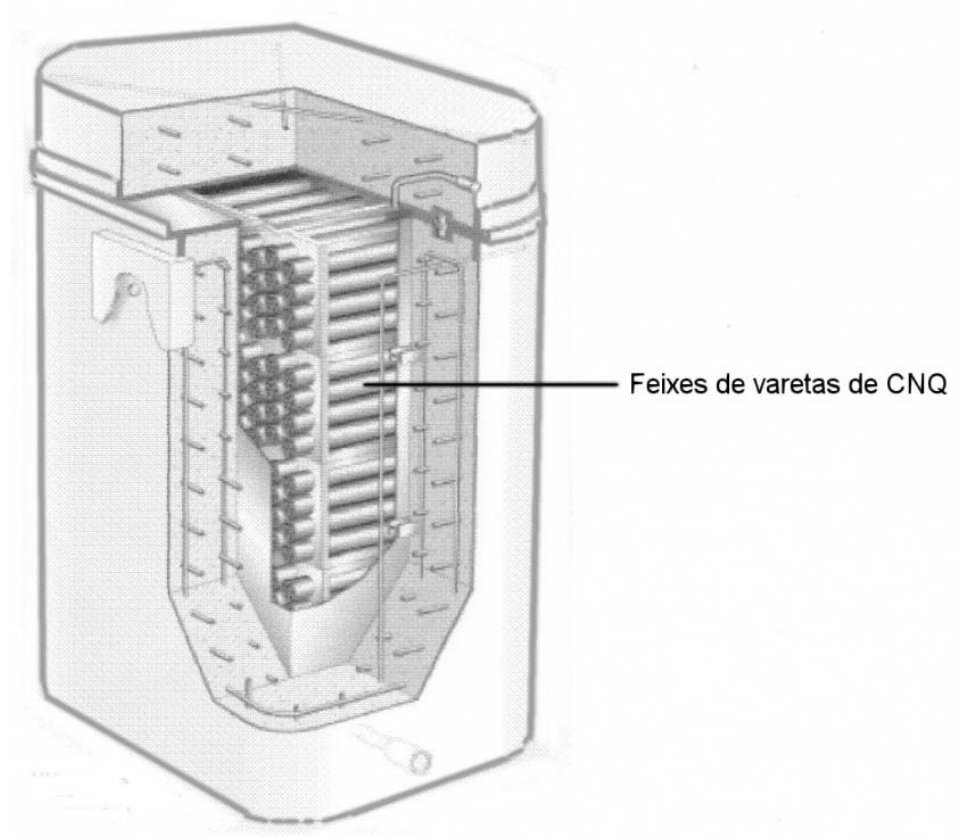

Figura 13 - Casco para armazenagem seca de CNQ tipo CANDU (Canadá) acomodado na posição horizontal em casco na posição vertical

Fonte: Adaptado de Ontario Power Generation (2009)

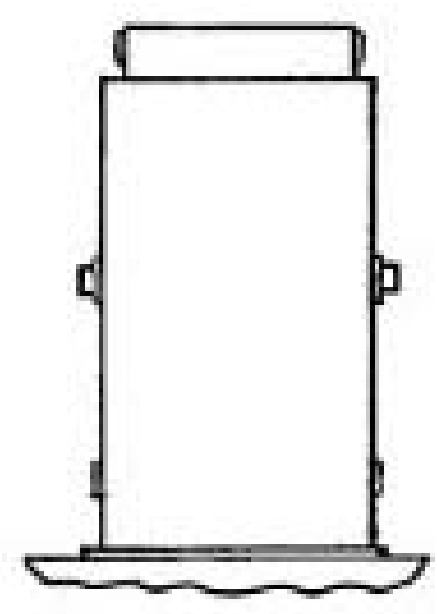

$\mathbf{A}$

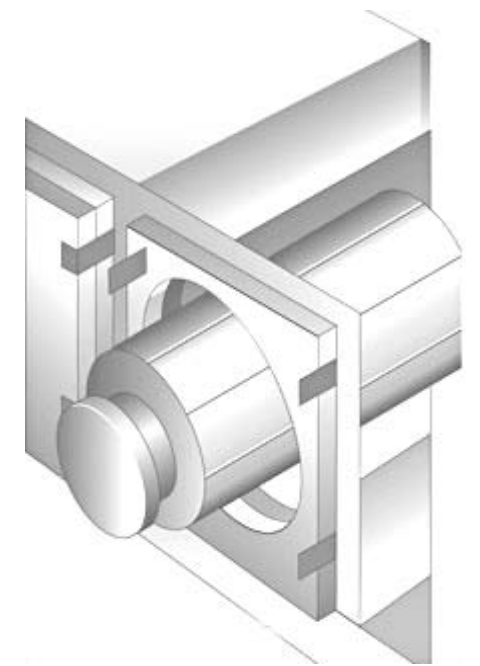

B

Figura 14 - Casco com CNQ na posição vertical (A) e horizontal (B). Fonte: (A) Lusk; Ridihalgh (1987); (B) USNRC, 2007a 
- Paredes do casco metálico

Os cascos metálicos podem ser constituídos de várias camadas de metais, com parede simples ou em camadas múltiplas, que proporcionam uma eficiência maior na blindagem contra a radiação gama. Neste caso, podem ser utilizados chumbo, urânio exaurido ou outros, como o tungstênio (Andersson; Andrews, 2001). Como a espessura do material de blindagem gama é proporcional a sua densidade, para a mesma atividade da fonte, quanto maior a densidade do material, menor a espessura, gerando economia de espaço de armazenagem.

O casco pode ser formado por um cilindro interno em aço inoxidável e uma carcaça externa, também de aço inoxidável, ambos concêntricos e com espaçamento interno entre ambas (Figura 15). O espaço entre os cilindros pode ser preenchido com o material de blindagem.

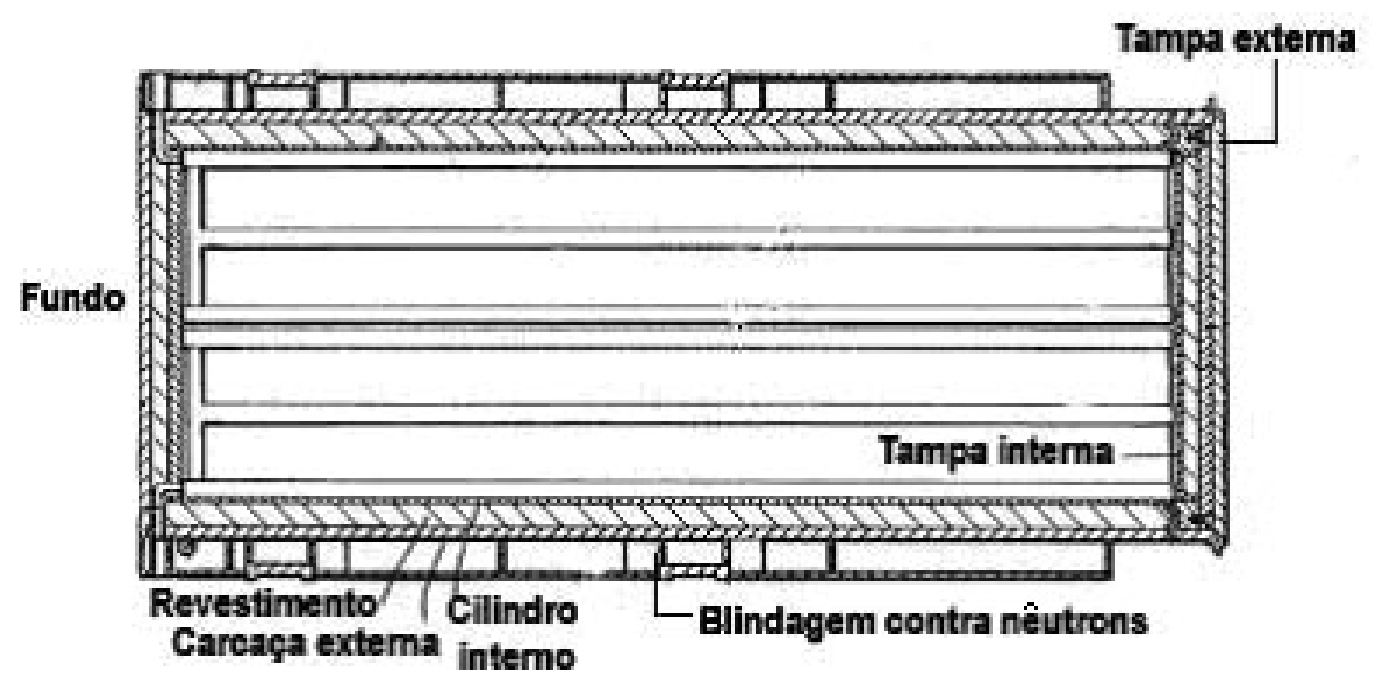

Figura 15 - Corte de um casco metálico de armazenagem de CNQ.

Fonte: Adaptado de Lusk; Ridihalgh (1987).

O fundo do casco pode ser constituído por duas placas de aço inoxidável, uma externa e outra interna. O espaço entre as placas do fundo pode ser preenchido com material de blindagem. Como alternativa, a placa do fundo pode ser de aço inoxidável com espessura maior.

- Cestos para o CNQ

$\mathrm{Na}$ cavidade cilíndrica interna do casco são acomodados os cestos de armazenagem de CNQ, como pode ser visto na Figura 16. 


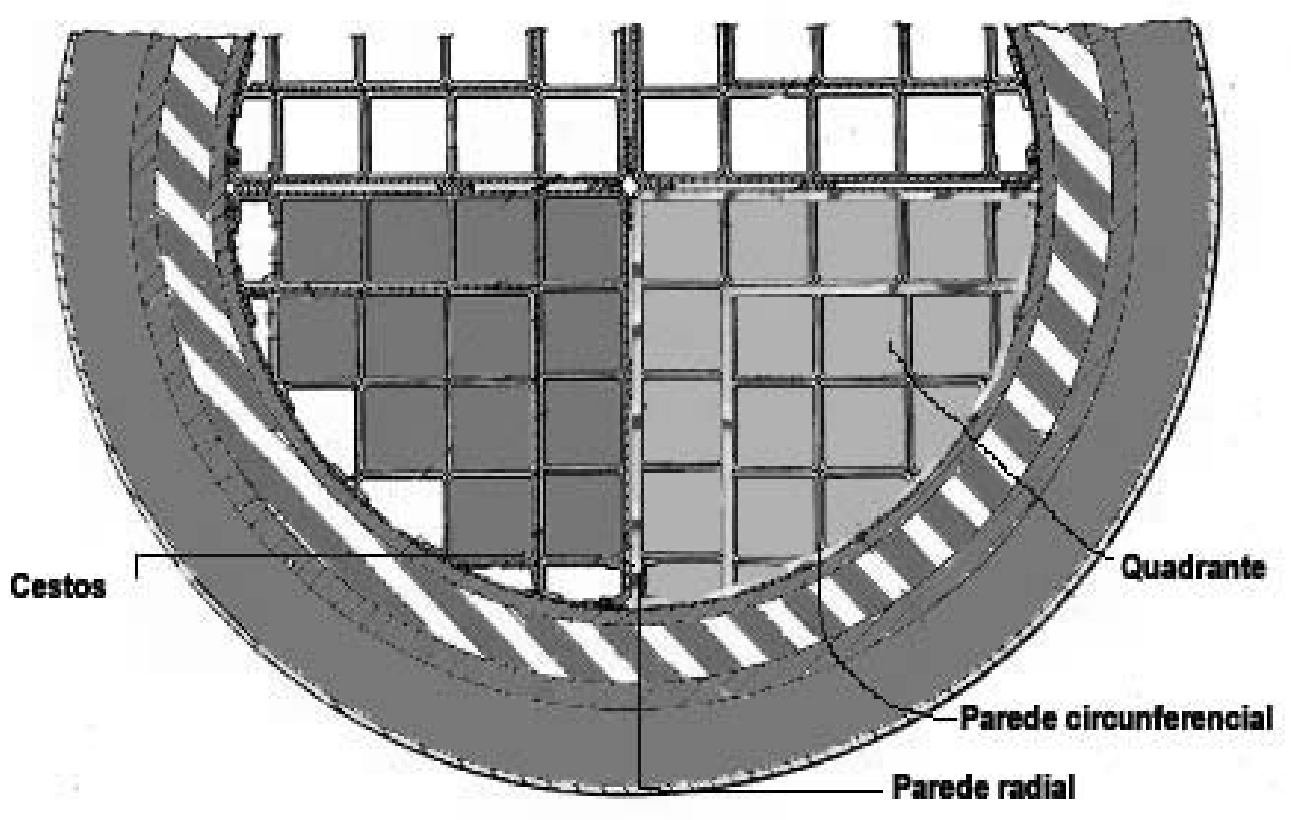

Figura 16 - Corte transversal de um casco metálico de armazenagem de CNQ. Fonte: Adaptado de Lusk; Ridihalgh (1987).

Os cestos para CNQ se ajustam de tal forma que ocupam, junto com o gás inerte, todo o volume útil da câmara. Para obter um conjunto estruturalmente rígido, as células do cesto podem ser circundadas por discos perfurados, distanciados entre si por espaçadores, como mostra a Figura 17.

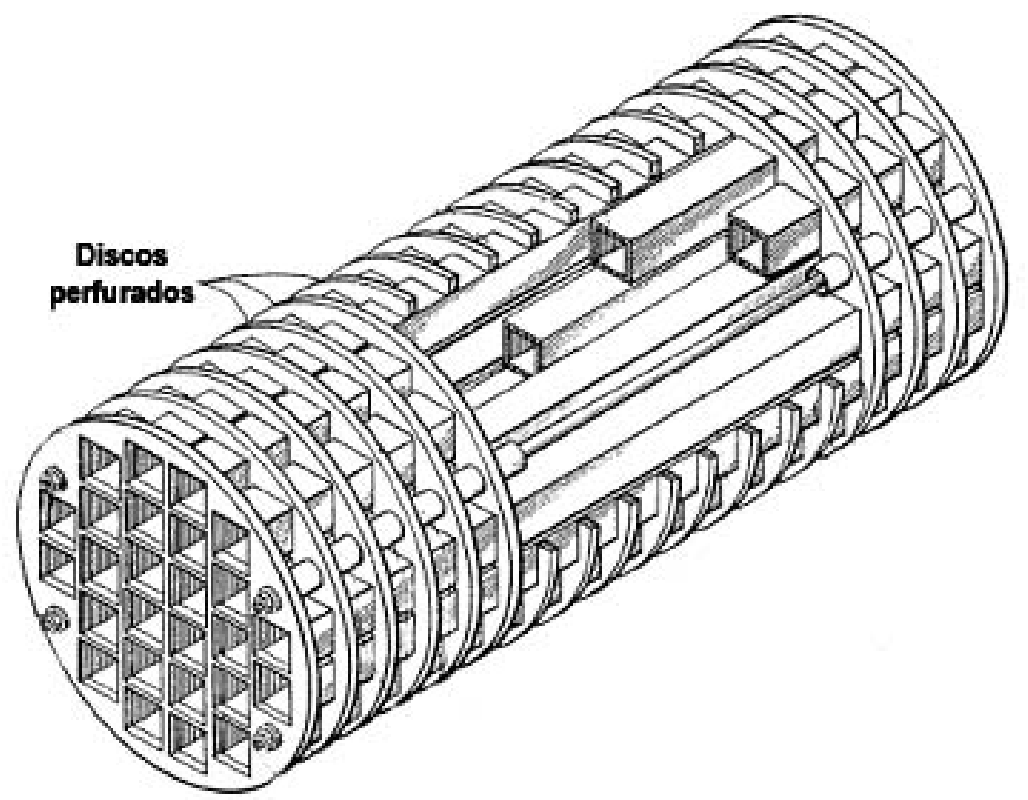

Figura 17 - Cesto usado em um casco para armazenagem de CNQ-PWR. Fonte: Adaptado de Wells (1990). 
Em outro modelo de cesto (Figura 18), as células são introduzidas em estruturas conhecidas como "embalagem de ovos", isto é, sucessivamente umas sobre outras (Blum e Meyer, 1991).

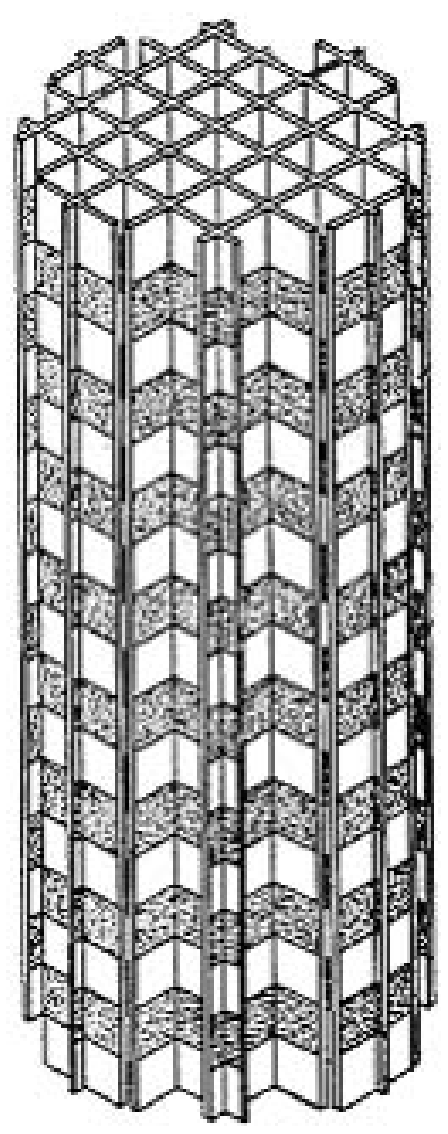

Figura 18 - Cesto interno de um casco de armazenagem de CNQ, tipo 'embalagem de ovos'.

Fonte: Blum; Meyer (1991).

Os cestos servem de apoio estrutural, absorvem nêutrons para assegurar a subcriticalidade e ajudam a dissipar o calor do CNQ. O cesto deve poder suportar os limites de temperatura para que não ocorra a fusão de seus materiais componentes. Esses materiais não podem ser deformáveis com facilidade (Shappert et al., 1998).

Os cestos são confeccionados com materiais estruturais, por exemplo, chapas de aço inoxidável, que envolvem placas absorvedoras de nêutrons de carboneto de boro em alumínio ou aço inoxidável, com seção quadrada (Lusk e Ridihalgh, 1987). O absorvedor de nêutrons pode ser disperso na matriz dos próprios materiais. A utilização de ligas com materiais absorvedores de nêutrons resulta em massa menor que a das chapas soldadas, mas tem como desvantagem o alto custo. Cada célula (Figura 19) pode receber apenas um elemento CNQ. 


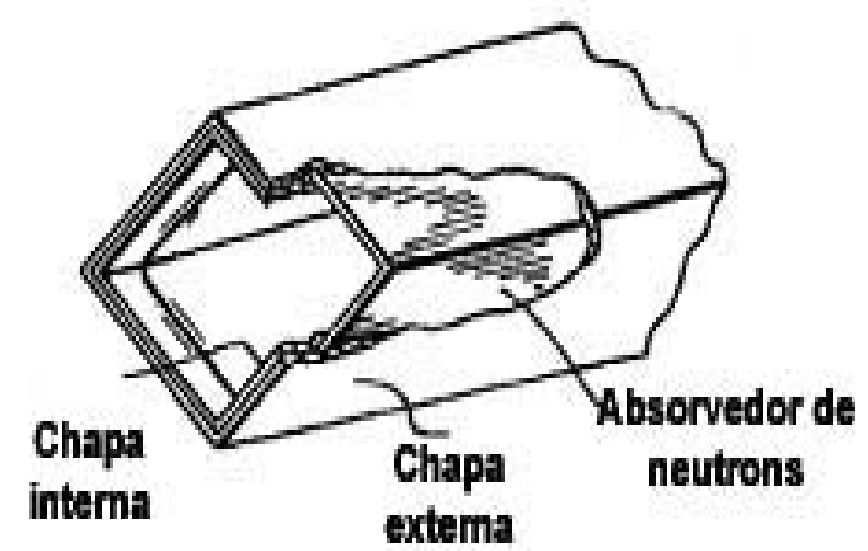

Figura 19 - Detalhe de uma célula de armazenagem.

Fonte: Adaptado de Lusk; Ridihalgh (1987).

As placas absorvedoras de nêutrons, capturam os nêutrons térmicos $(<0,5 \mathrm{eV})$ (Hondorp, 1984).

Para propiciar a transferência de calor entre as células, podem ser introduzidas placas de cobre e espaçadores de aço inoxidável de modo que os módulos sejam pressionados uns contra os outros, o que proporciona rigidez ao conjunto.

Para blindar nêutrons térmicos, os cestos são construídos com tubos de secção quadrada com boro localizado entre as células adjacentes. Um método para melhorar a capacidade de blindagem é a inserção de um espaço entre as duas camadas do material absorvedor com espaçadores estruturais entre os tubos adjacentes. Outra forma é a aplicação de armadilha de fluxo que consiste de uma estrutura de aço dobrada de modo que a geometria resultante forme uma "espinha dorsal" entre as células de CNQ. Essa estrutura, aliada à blindagem para nêutrons na parte externa do casco, visa absorver nêutrons de todas as energias: lentos e rápidos, gerados no $\mathrm{CNQ}$, para que não ocorra vazamento para $\mathrm{o}$ meio ambiente. (Shappert et al., 1998)

\section{- Tampas de fechamento}

A Figura 20 mostra detalhes da instalação da tampa após o carregamento do CNQ nos cascos. O sistema de fechamento do casco é feito na parte interna e externo. A parte interna é composta por três placas: a central de chumbo e as externas de aço ou ferro. Esta tampa interna é aparafusada no casco e, entre ela e o casco são colocados dois anéis metálicos que propiciam maior estanqueidade após o fechamento. 


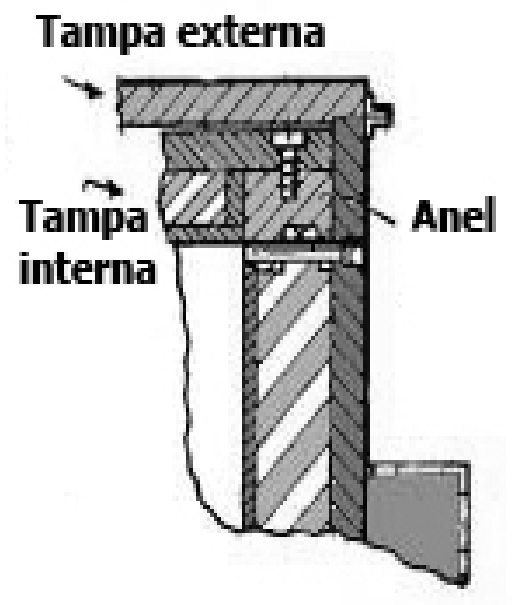

Figura 20 - Detalhe da tampa de um casco metálico de armazenagem.

Fonte: Adaptado de Lusk; Ridihalgh (1987)

\begin{abstract}
A tampa externa é colocada sobre a interna e soldada no casco após o preenchimento do mesmo com gás inerte. $\mathrm{O}$ casco, assim como o cesto de contenção dos elementos de CNQ, também deve possuir uma proteção contra nêutrons.
\end{abstract}

- Munhões externos de elevação e translação

O conjunto de elevação é composto por munhões superior e inferior que são aparafusados em suportes (Figuras 21 e 22). A possibilidade de retirada dos munhões após o término da operação (elevação e manuseio) previne a ocorrência de impactos que podem danificar a estrutura. 


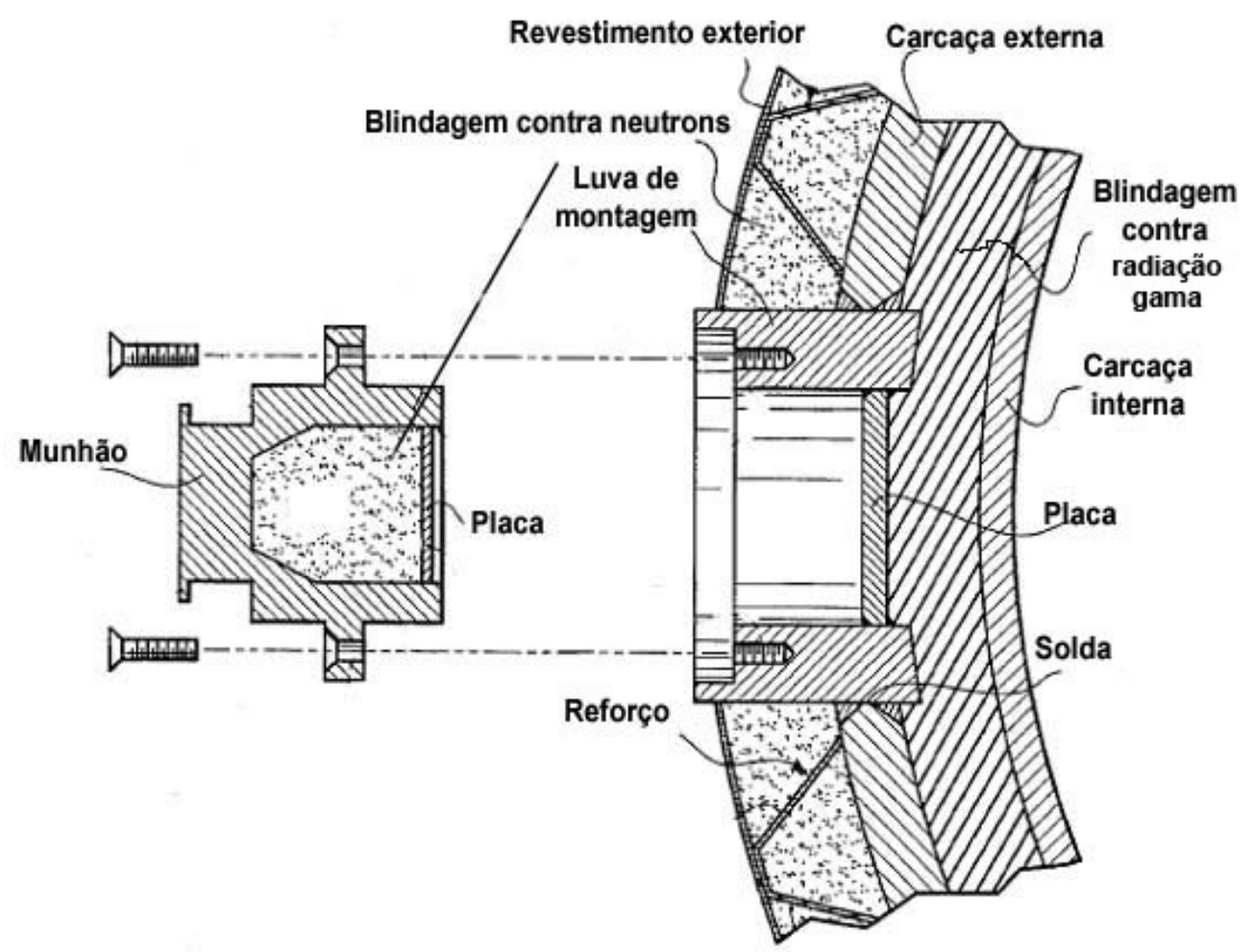

Figura 21 - Detalhe do munhão superior de um casco metálico de armazenagem de CNQ. Fonte: Adaptado de Jones et al. (1996).

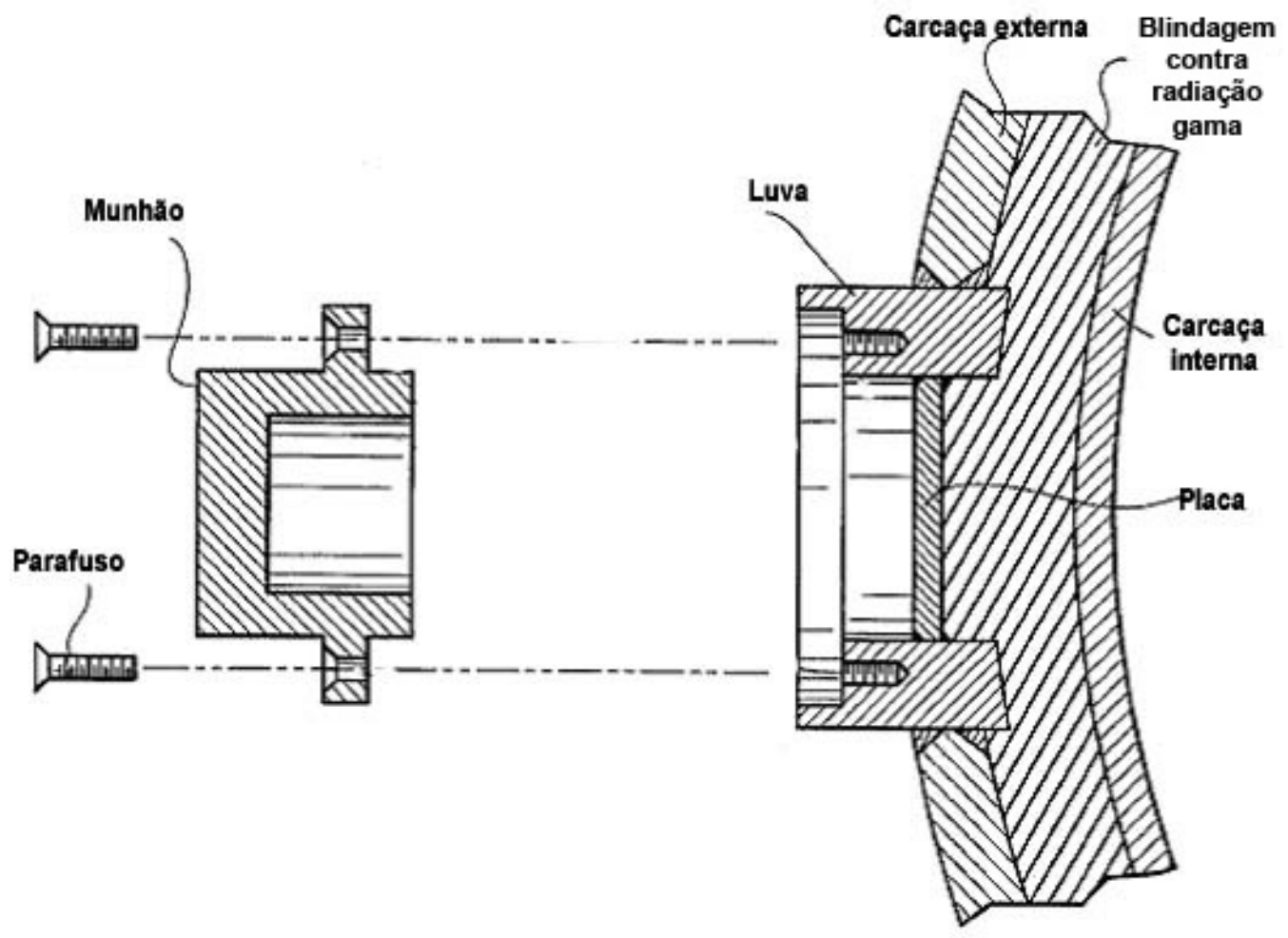

Figura 22 - Detalhe do munhão inferior de um casco metálico de armazenagem. Fonte: Adaptado de Jones et al (1996). 
- Válvulas e drenos

O casco é provido de drenos, que são conexões que possibilitam o escoamento de água, como mostrado na Figura 23, e de válvulas para inserção do gás inerte. Esses devem possuir retentor e uma tampa de proteção.

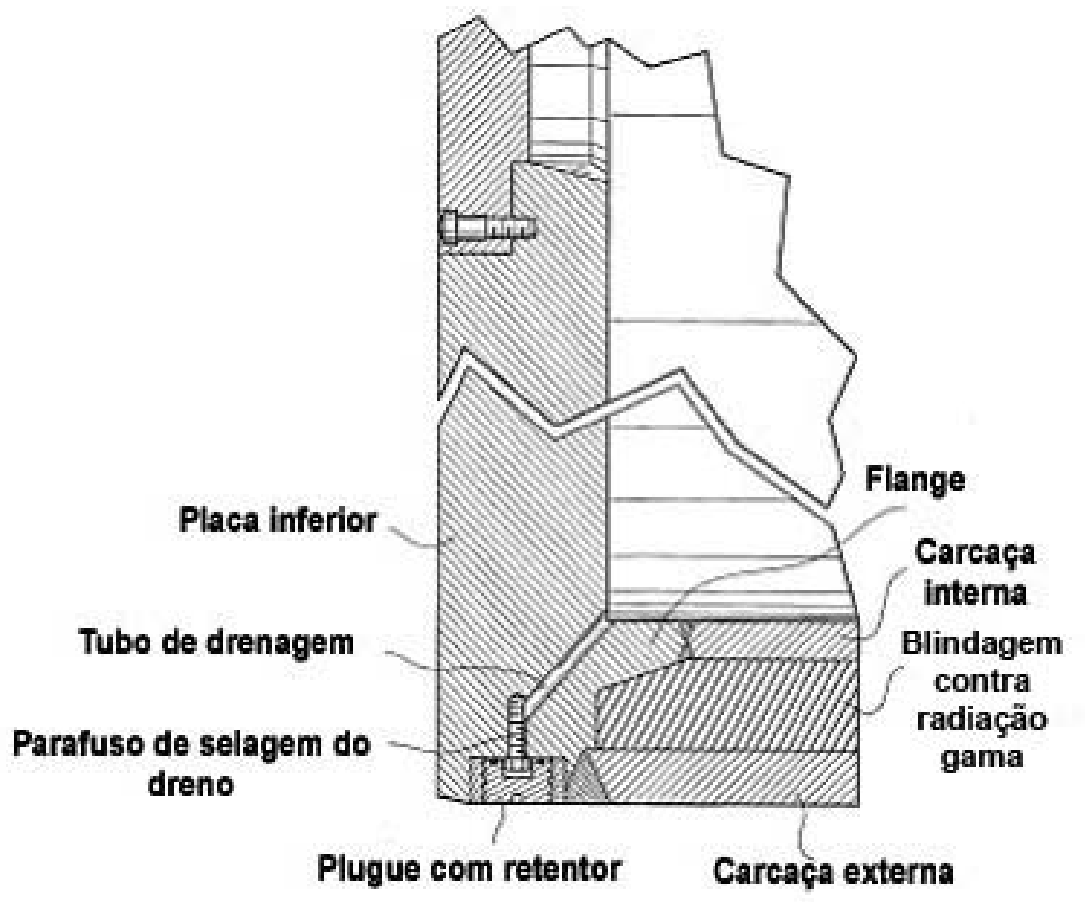

Figura 23 - Detalhe do fundo de um casco metálico de armazenagem de CNQ.

Fonte: Adaptado de Jones et al (1996).

Na Figura 24 é mostrado um casco metálico em sua totalidade que inclui os absorvedores de impacto, frontal e traseiro (superior e inferior), e o limitador lateral de impacto, utilizados para transporte.

- Limitadores de impacto e absorvedores de impacto

Os limitadores de impacto laterais, superiores e inferiores (esses dois últimos também conhecidos como amortecedores de impacto) são instalados no casco apenas para transporte em vias públicas. Para o transporte do casco no mesmo sítio do reator são desnecessários. Normalmente, os amortecedores de impacto são construídos para amortecer o impacto no casco e no seu conteúdo e, para proteção térmica. A deformação dos absorvedores de impacto propicia uma baixa desaceleração, seja no casco como em seu conteúdo, diminuindo a possibilidade de dano estrutural. A desvantagem de sua utilização é o aumento da massa do conjunto no transporte. 
Os materiais utilizados para a fabricação dos absorvedores de impacto podem ser deformáveis (madeira ou uma colméia de alumínio) ou espumas rígidas, pois a resposta elástica não é desejável, e ainda podem ser envoltos por uma chapa metálica.

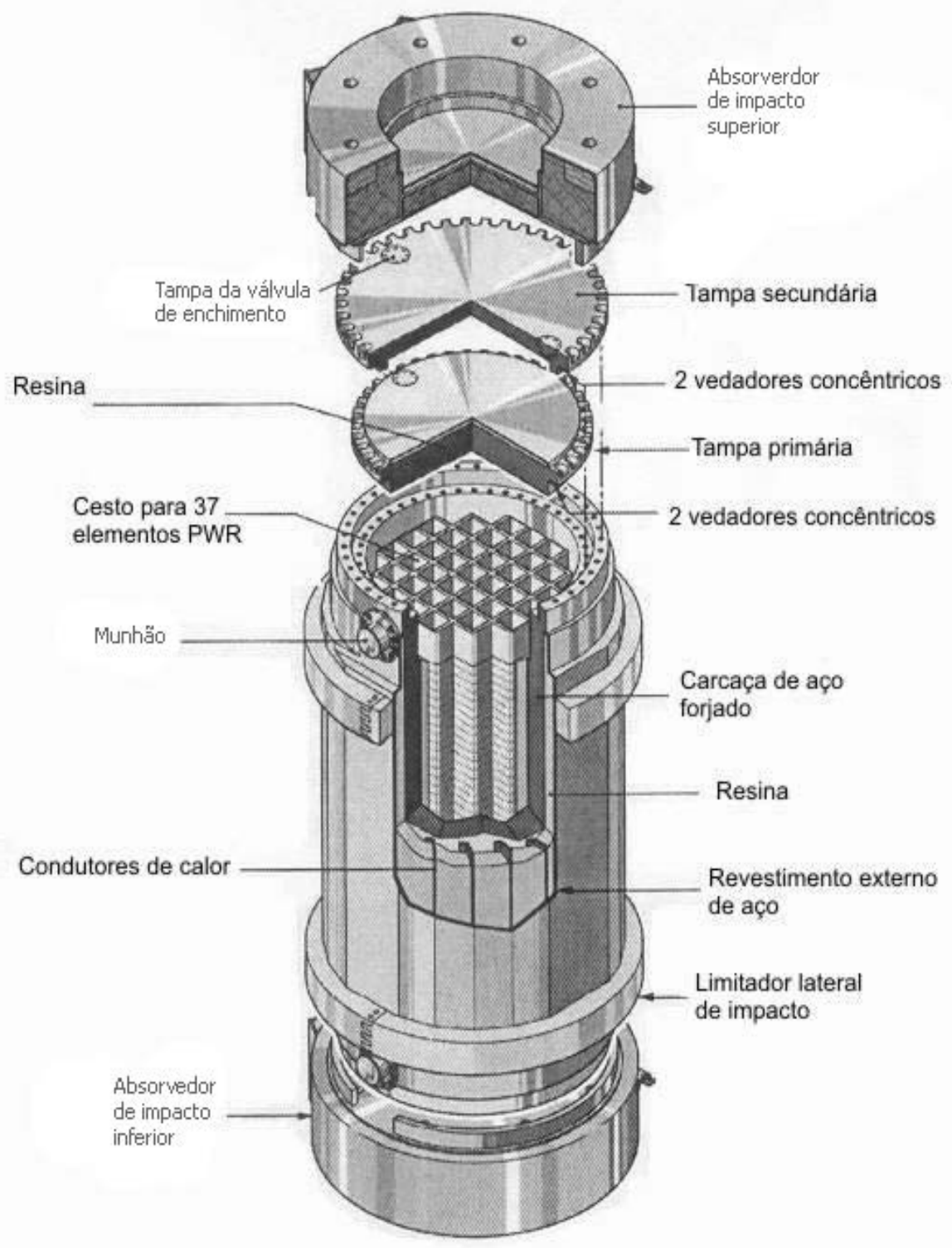

Figura 24 - Casco metálico para transporte, armazenagem e deslocamento na instalação de CNQ-PWR, tipo TN24 da Transnucléaire (França).

Fonte: Adaptado de Verdier et al. (2003).

Na Figura 25 é mostrado o protótipo do casco e o absorvedor de impacto após a realização do teste de queda de $9 \mathrm{~m}$ de altura. Após o término do teste, o absorvedor ficou danificado. Na Figura 26 observa-se a estrutura interior, de madeira, do absorvedor de impacto que absorveu o impacto e o envoltório metálico que sofreu ruptura durante o teste. Tanto o casco como seu conteúdo não sofreram danos (Romanato, 2008). 


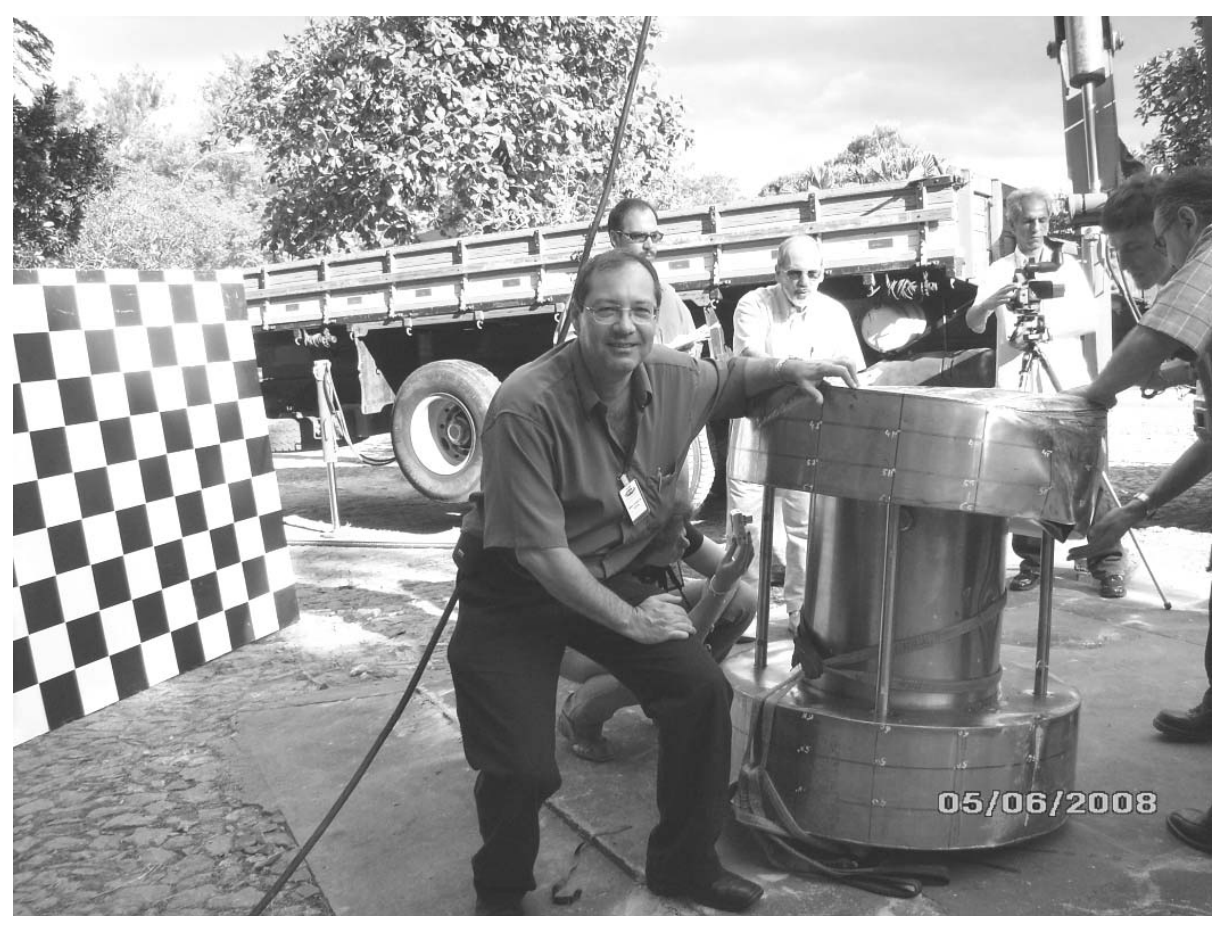

Figura 25 - Protótipo de casco após queda de $9 \mathrm{~m}$. Fonte: Romanato (2008); Foto: Romanato, L. S.

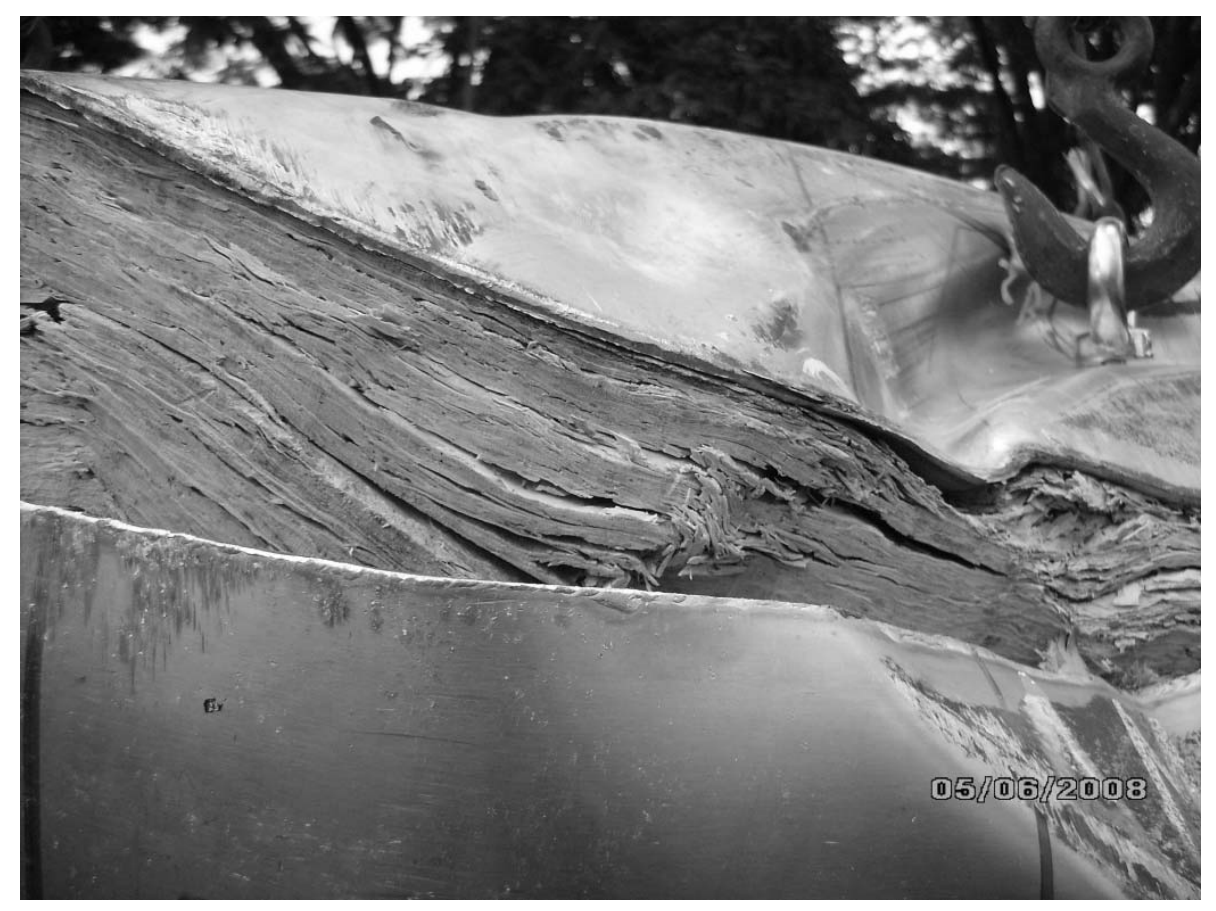

Figura 26 - Detalhe do absorvedor de impacto após impacto resultante da queda de $9 \mathrm{~m}$. Fonte: Romanato (2008); Foto: Romanato, L. S. 


\subsubsection{Cascos de concreto}

Os cascos de concreto armado têm a mesma disposição interna dos cascos metálicos, e o CNQ fica distribuído internamente em cestos de alumínio ou de aço inoxidável. Os cilindros externos, de concreto, servem como blindagem contra nêutrons com energias menores que $1 \mathrm{MeV}$ e radiação gama. Para aumentar o poder de blindagem da radiação gama a composição do concreto pode ser modificada com materiais de densidade superior. Se no lugar de brita for usada a barita, a densidade do concreto torna-se mais elevada, ao redor de $3,5-4,1 \mathrm{~g} / \mathrm{cm}^{3}$. (Luz e Baltar, 2005).

Geralmente os cascos de concreto (Figura 27) são mais pesados que os metálicos, por causa da espessura das paredes, porém, têm como vantagem o custo mais baixo. Na Figura 27 observa-se também dutos especialmente planejados e localizados nos topos inferior e superior dos cilindros para a troca de calor. $\mathrm{O}$ ar entra pelas aberturas inferiores e sai pelas superiores (casco na posição vertical).

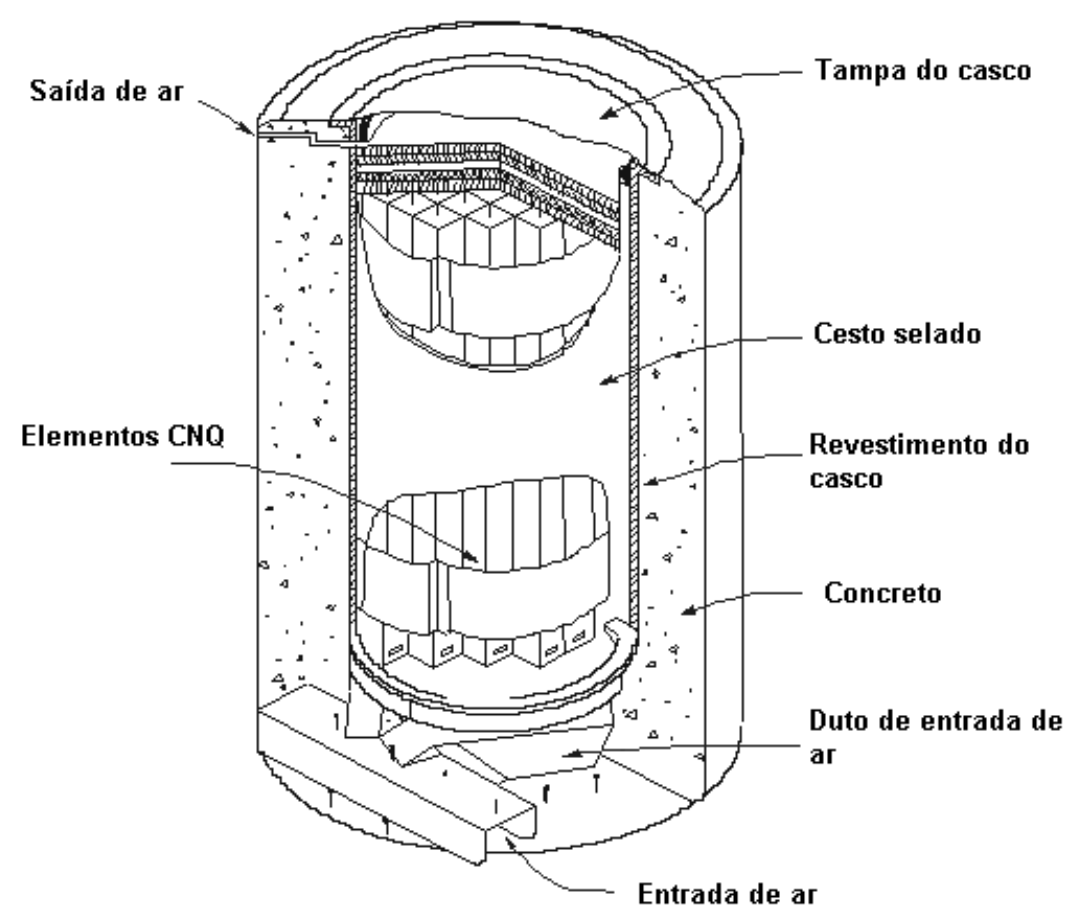

Figura 27 - Corte de um casco de concreto para armazenagem de CNQ.

Fonte: Adaptado de Oak Ridge National Laboratory.

O casco denominado "casco de concreto ventilado", Figura 28, foi desenvolvido para atender a usina de Zaporizhzhya, Ucrânia (Zaporizhzhya, 2008). 


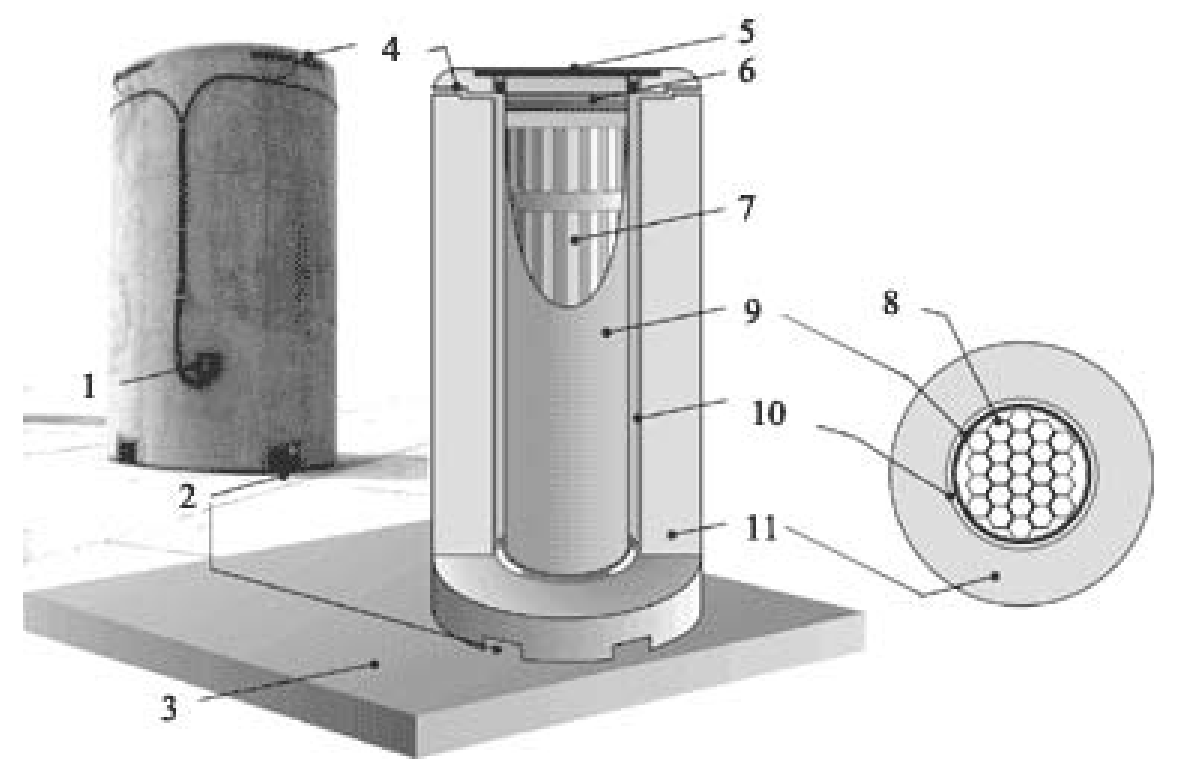

1. Sensor de controle de 4 . Saída de ar temperatura 5 5. Tampa do casco de concreto 2. Entrada de ar e guia para 6. Tampa blindada do cesto transporte

3. Piso de concreto

7. Cesto para 24 elementos $\mathrm{CNQ}$

8. Tubos guia

9. Carcaça do cesto
10. Cobertura
11. Parede externa do casco de
concreto ventilado

Figura 28 - Casco de concreto para armazenagem de CNQ

Fonte: Zaporizhzhya (2008)

Os cascos de concreto CONSTOR ${ }^{\circledR}$ (Figura 29), construídos na Alemanha pela GNS (General Nuclear Services Inc.) e vendidos para diversos países, foram desenvolvidos a partir de meados de 1990. Foram utilizados materiais mais comuns como o concreto de forma a baratear o custo final do produto, sem prejudicar os requisitos de transporte e segurança que são observados para os cascos metálicos. Até o ano de 2002 a Alemanha construiu 30 desses cascos que foram utilizados com sucesso na armazenagem de CNQ. (Vossnacke et al., 2003) Em 2005, a GNS anunciou a intenção de licenciá-los nos EUA para começar a fabricá-los em 2007 no território americano. No concreto deste casco, a GNS usou grânulos de ferro para fins de blindagem. A empresa tem a intenção de substituir estes cascos CONSTOR de concreto pesado por cascos de nova geração, que serão denominados DUCRETE ${ }^{\mathrm{TM}}$, nos quais pretendem reduzir a matriz de elementos combustíveis para que este sirva para qualquer tipo de combustível, seja barato e seja produzido ou um casco diferente produzido com a nova tecnologia cermet-aço-DUO ${ }_{2}$. 


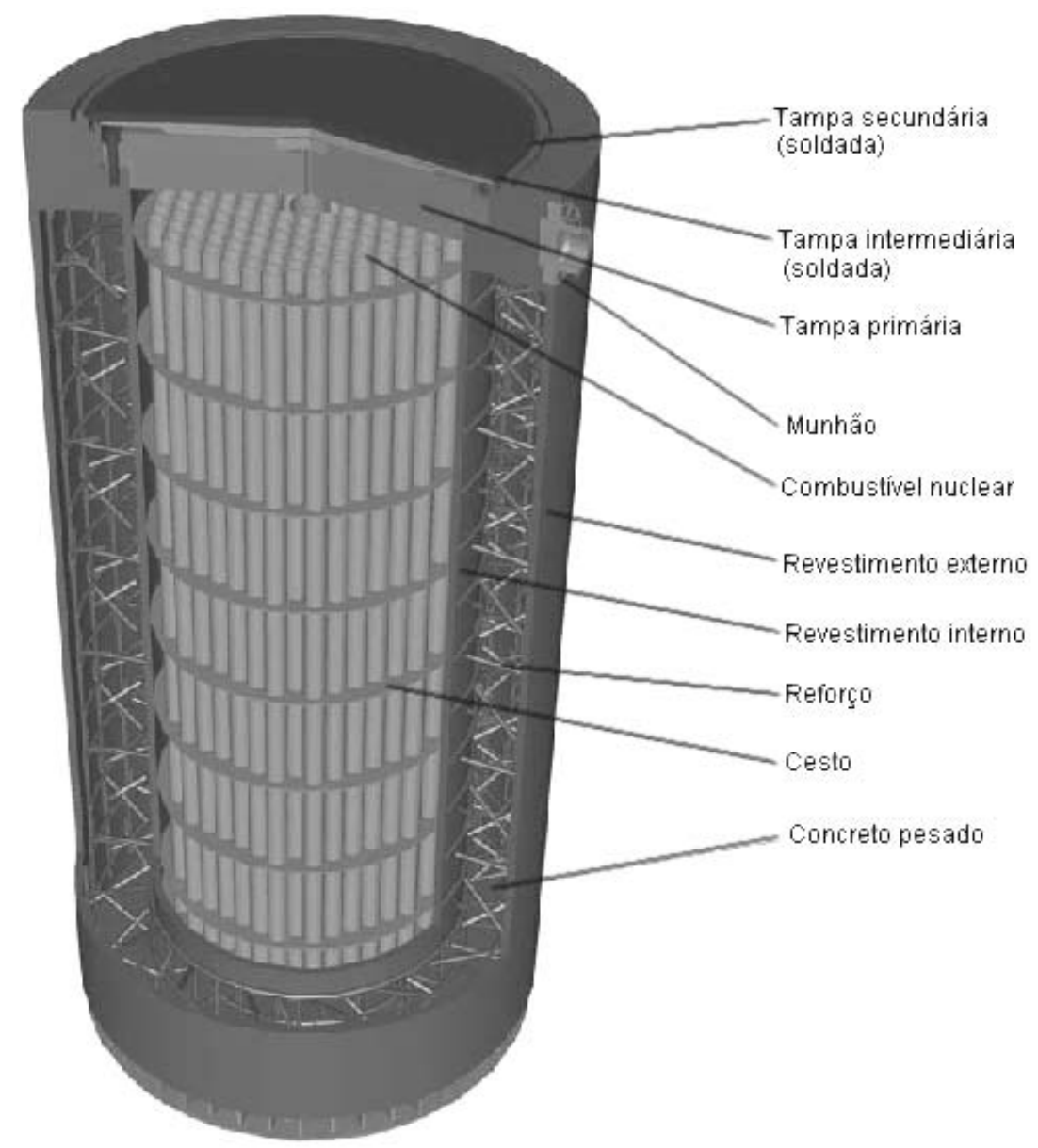

Figura 29 - Corte de um Casco CONSTOR ${ }^{\circledR}$ para acondicionamento de CNQ, transporte e armazenagem.

Fonte: Adaptado de Haire et al. (2003)

\subsubsection{Cascos de materiais estruturais especiais}

O Departamento de Energia dos Estados Unidos está estudando a construção de cascos de urânio exaurido (DU - Depleted Uranium) agregado aos ingredientes para confecção do concreto. Este agregado permite produzir concreto com densidades entre $5,6 \mathrm{~g} / \mathrm{cm}^{3}$ e $6,4 \mathrm{~g} / \mathrm{cm}^{3}$ (o concreto convencional possui densidade perto de $2,4 \mathrm{~g} / \mathrm{cm}^{3}$ ). De acordo com Quapp (1999), essa densidade é efetiva na atenuação de radiações gama e nêutrons.

Na Figura 30 é apresentado o gráfico que compara a taxa de exposição na parte exterior do casco, medida na superfície, quando é utilizado um composto com urânio exaurido denominado cermet (50\% ou $90 \%$ na composição) e uma parede de aço inoxidável. Pode ser verificado que, quanto maior a porcentagem de urânio exaurido na composição do casco, menor é a espessura da parede para uma mesma taxa de exposição (Forsberg, 2004). 


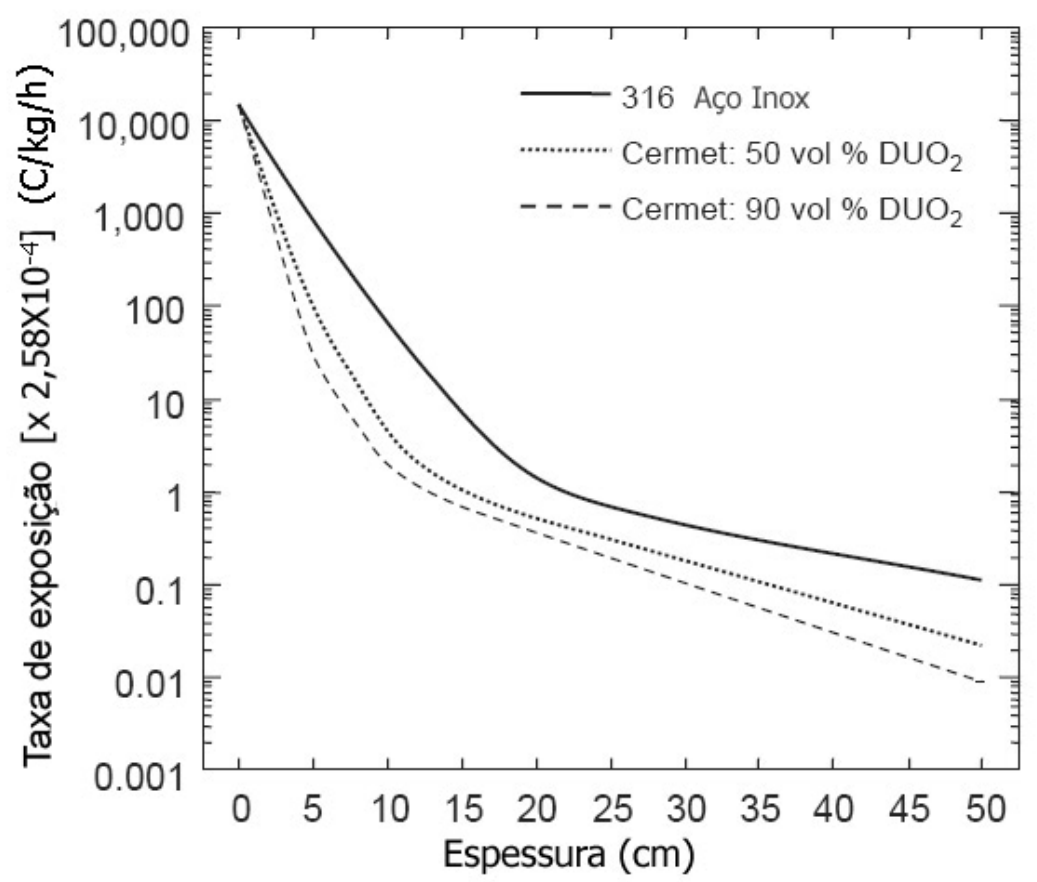

Figura 30 - Taxas de exposição na superfície de um casco para CNQ com relação à espessura da parede.

Fonte: Adaptado de Forsberg (2004)

\subsubsection{Manuseio do casco carregado}

O manuseio do casco, que abrange elevação, abaixamento e translação é feito por meio de munhões amovíveis, posicionados em locais da superfície externa e que permitem engate por talhas ou guindastes (Best et al., 1982), como mostram as Figuras 31 e 32. Desta forma, o casco pode ser deslocado, colocado em veículos de transporte e depois tirado do veículo de transporte e levado para o local de armazenagem. 


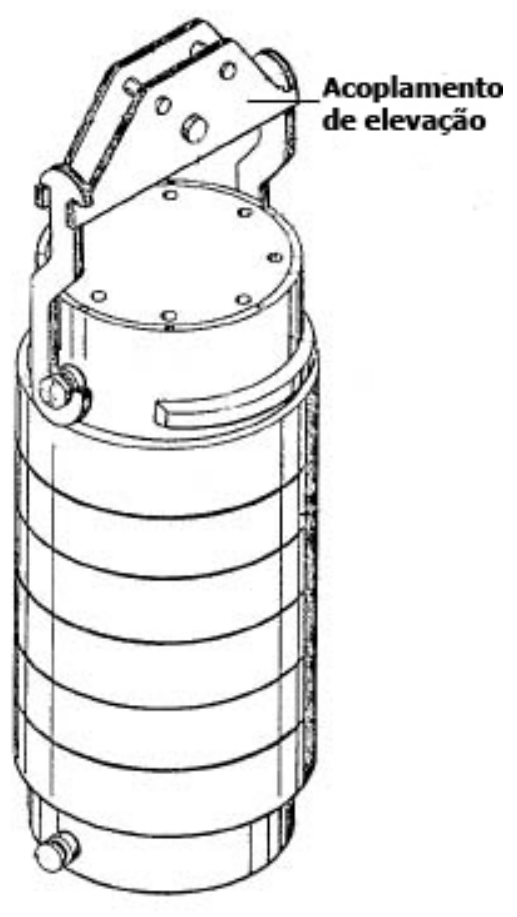

Figura 31- Fixação do acoplamento de elevação no casco com CNQ. Fonte: Adaptado de Best et al. (1982).

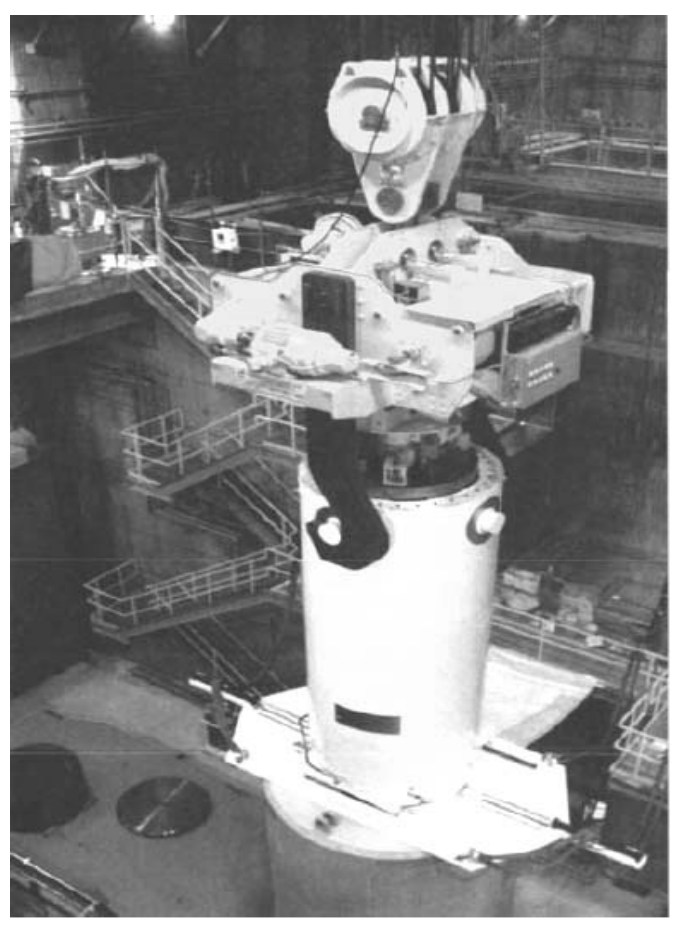

Figura 32 - Sistema acoplado aos ganchos para elevação de um casco com CNQ. Fonte: IAEA (2005) 


\title{
3.2.2.5 Descontaminação da superfície externa do casco carregado com $C N Q$
}

A superfície externa do casco pode ser contaminada pela água da piscina no caso da imersão do mesmo por carregamento ou por respingos no caso da retirada do CNQ e inserção no casco em célula quente.

Os cascos metálicos ou de aço inoxidável podem ter a superfície pintada. Os de concreto podem, ou não, ser revestidos com aço inoxidável ou podem ficar com a parede de concreto aparente. Esse último não é inserido na piscina e a transferência do CNQ para dentro dele é feita por meio de dispositivos de retirada e transferência, ou um cilindro que é inserido no casco metálico e mergulhado na piscina, para ser carregado com o CNQ. Neste caso, a descontaminação neste cilindro é feita posteriormente e o cilindro carregado é introduzido no casco definitivo. (Severa e Bar, 1991)

Após o carregamento do CNQ no casco e seu fechamento, a liberação só é feita após os testes para verificação da contaminação superficial. Caso a superfície externa esteja contaminada por acusar valores acima dos limites estabelecidos por norma, esta deve ser descontaminada por meio de diferentes técnicas de descontaminação, dependendo da superfície. Os métodos de descontaminação do casco são geralmente lavagem com água, métodos mecânicos como escovação e abrasão, meios químicos com detergentes, solventes, desengraxantes, métodos eletroquímicos, ou outros métodos. (IAEA, 1999a)

\subsubsection{Cascos existentes}

Para armazenagem seca de combustível nuclear queimado de reatores PWR, existem os modelos de cascos seguintes:

\begin{abstract}
Alemanha - O casco CASTOR, desenvolvido pela empresa GNS, para transporte e armazenagem de CNQ, é composto por uma carcaça de ferro fundido monolítico com tampas aparafusadas. A carcaça tem espessura de $0,285 \mathrm{~m}$ e proporciona contenção e blindagem contra a radiação do CNQ durante a armazenagem e contra acidentes em condições normais de transporte. O CNQ é acondicionado em cestos de aço. O resfriamento é feito por meio de convecção de ar que passa por aletas no corpo do casco.
\end{abstract} (IAEA, 2000)

Estados Unidos - Os modelos Hi-Star / Hi-Storm foram desenvolvidos pela empresa Holtec International. Existem três tipos de cilindros com as mesmas dimensões externas e servem para armazenar CNQ gerado em reatores PWR e BWR. O modelo MPC- 
68 foi projetado para 68 elementos CNQ-BWR, com enriquecimento inicial máximo de $4,2 \%{ }^{235} \mathrm{U}$, o modelo MPC-24, para 24 elementos CNQ-PWR com enriquecimento inicial de $4,6 \%{ }^{235} \mathrm{U}$ e o modelo MPC-32 para 32 elementos CNQ-PWR com enriquecimento inicial de 5,0\% ${ }^{235} \mathrm{U}$. Esse último modelo, até a data da publicação dessas informações na literatura, não havia sido licenciado pela United States Nuclear Regulatory Commission. (IAEA, 2000)

Cada modelo consiste de um cilindro interno e um invólucro externo. Os modelos compõem o sistema Hi-Star e o sistema Hi-Storm. Os cilindros para elementos gerados em reatores PWR e BWR são os mesmos e podem ser utilizados com ambos os invólucros.

Cilindros internos são construídos de liga de aço e possuem os cestos de combustível descritos como uma geometria tipo colméia. As massas máximas de projeto dos cilindros MPC-68, MPC-24 e MPC-32 são, respectivamente, $40.000 \mathrm{~kg}, 36.300 \mathrm{~kg}$ e $41.000 \mathrm{~kg}$. Os cilindros MPC são inseridos nos invólucros externos dos sistemas Hi-Star e Hi-Storm.

O invólucro do Hi-Star consiste de camadas de liga de aço com um composto de blindagem de nêutrons específico denominado Holtite-A. O invólucro tem 5,16m de comprimento, 2,44m de diâmetro externo e 1,75m de diâmetro interno. A massa do conjunto, quando carregado (massa máxima com os absorvedores de impacto), é de $112.000 \mathrm{~kg}$. A tampa de fechamento, aparafusada, possui dois anéis o'ring metálicos para isolamento total do CNQ dentro do casco. O conjunto é preenchido com gás hélio e é transportado na posição horizontal.

Ao utilizar o sistema $\mathrm{Hi}$-Storm, o transporte e a armazenagem são feitos com o conjunto na vertical sem utilização de absorvedores de impactos. O invólucro é um cilindro vertical ventilado, com estrutura de concreto com revestimento de aço. Sua altura é de $5,87 \mathrm{~m}, 3,37 \mathrm{~m}$ de diâmetro externo e $1,87 \mathrm{~m}$ de diâmetro interno. O conjunto vazio tem massa $122.000 \mathrm{~kg}$ e quando carregado a massa chega a atingir $162.500 \mathrm{~kg}$. Possui quatro dutos no topo superior e no inferior para resfriamento do cilindro interno por convecção natural de ar.

O sistema Hi-Star, utilizado no transporte e armazenagem de CNQ, é um invólucro único. Pode ser utilizado para armazenagem no local do reator e no transporte do CNQ para outra localidade. Se for utilizada uma combinação Hi-Star / Hi-Storm, o cilindro interno carregado com CNQ deve ser transferido do invólucro Hi-Star para o Hi-Storm. A transferência do cilindro interno de um invólucro para outro requer o uso de um dispositivo 
chamado Hi-Trac. Se for utilizado o sistema com o invólucro Hi-Storm para armazenagem no local do reator, quando da transferência do CNQ para uma instalação de armazenagem provisória, por exemplo, o cilindro interno com o CNQ deve ser colocado no invólucro $\mathrm{Hi}$ Star. O invólucro Hi-Storm original, vazio, pode ser enviado à nova instalação e lá ser realizada uma nova transferência, ou pode ser utilizado o próprio invólucro Hi-Star na transferência para a armazenagem (IAEA, 2000). A Figura 33 mostra um corte do sistema Hi-Storm (Shah et al., 2003)

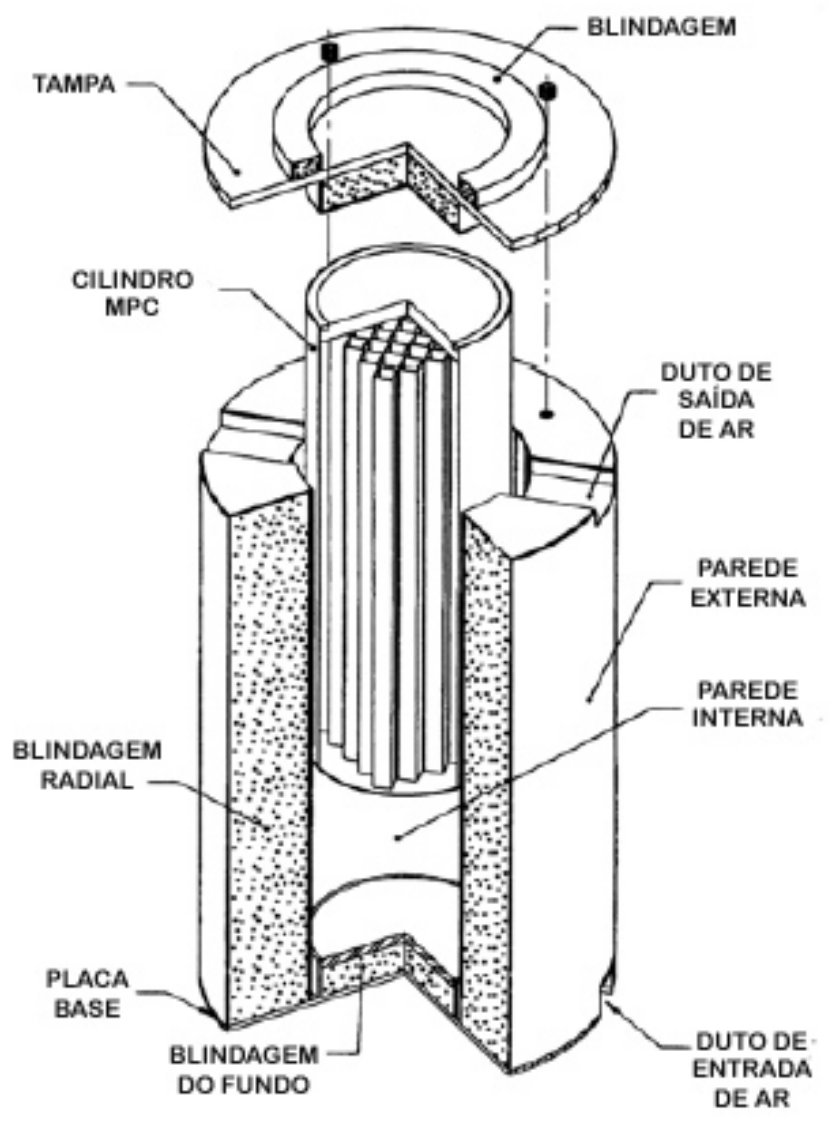

Figura 33 - Corte do sistema de armazenagem Hi-Storm. Fonte: Adaptado de Shah et al. (2003)

A empresa norte-americana NAC desenvolveu um modelo de casco metálico para transporte e armazenagem, denominado STC e projetado para 26 elementos CNQ gerados em reator PWR com enriquecimento inicial máximo de $4,2 \%$ de ${ }^{235} \mathrm{U}$, burnup máximo de $45 \mathrm{GWd} / \mathrm{tU}$ e tempo mínimo de resfriamento em piscina, após a retirada do reator, de 6,5 anos para transporte e 10 anos para armazenagem. O casco é composto por carcaças interna e externa, de aço inoxidável, separadas por uma camada de chumbo. Possui duas tampas de aço inoxidável e a contenção é feita por anéis o’ring metálicos. Na 
tampa primária se encontram localizados os orifícios de drenagem e ventilação. A tampa dupla facilita a verificação periódica de vazamentos pelos selos de contenção. O cesto é composto por aço inoxidável, denominado Boral, que é um moderador de nêutrons pois é enriquecido com boro em forma de painéis de alumínio. Para transporte, são utilizados limitadores de impacto de aço inoxidável preenchidos com madeira tipo balsa. $\mathrm{O}$ casco ainda possui quatro munhões de elevação. O conjunto carregado com CNQ tem massa de $116.000 \mathrm{~kg}$ e vazio $103.000 \mathrm{~kg}$. O diâmetro externo é de $2,52 \mathrm{~m}$, o interno $1,81 \mathrm{~m}$, a altura total $4,90 \mathrm{~m}$ e a altura da cavidade 4,19m. (IAEA, 2000)

Outro modelo da NAC é o UMS (Figura 34) para 24 elementos CNQ-PWR ou 56 elementos de reatores BWR. O sistema tem quatro componentes principais: o cilindro de armazenagem, que é transportável, o casco vertical de concreto, o casco de transporte e equipamentos auxiliares que incluem o cilindro de transferência. $O$ cilindro de transferência é utilizado durante a retirada da piscina do cilindro de armazenagem com o CNQ, transferindo-o para o casco de transporte. Novamente, após o transporte até o local de armazenagem, o cilindro de armazenagem é transferido do casco de transporte para o cilindro de transferência e posteriormente para o casco vertical de concreto. (NAC, 2008)

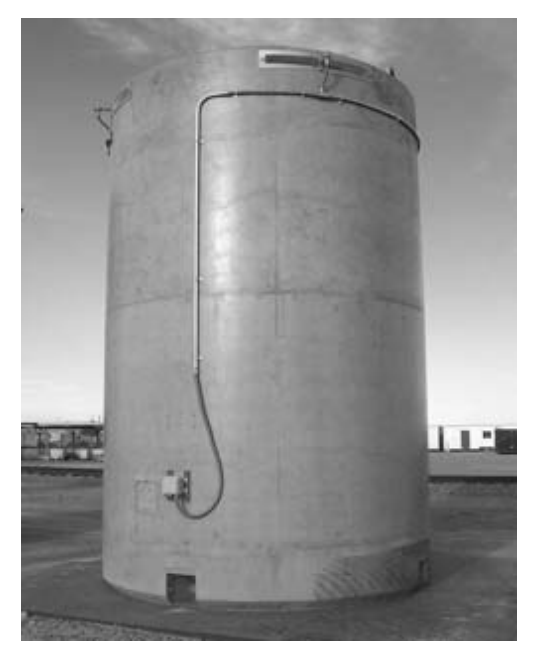

Figura 34 - Casco de armazenagem UMS, da NAC, para CNQ-PWR. Fonte: NAC (2008)

O cilindro transportável de armazenagem pode ter cinco alturas diferentes, entre $4,44 \mathrm{~m}$ e $4,88 \mathrm{~m}$, e todos com o mesmo diâmetro de $1,70 \mathrm{~m}$. O cilindro maior tem massa $19.000 \mathrm{~kg}$ quando vazio e $38.000 \mathrm{~kg}$ carregado. Todos os cilindros foram projetados com o cesto tipo tubo e disco (Figura 35). 
O casco de transporte é de aço inoxidável e chumbo com uma blindagem contra nêutrons de polímero sólido. Esse casco mede 5,31m de altura, 2,36m de diâmetro externo e serve para todos os tamanhos de cilindros de armazenagem. Os limitadores de impacto são de carcaça de aço inoxidável com preenchimento interior em madeira. A massa máxima do casco carregado é de $126.000 \mathrm{~kg}$ e é transportado na posição horizontal.
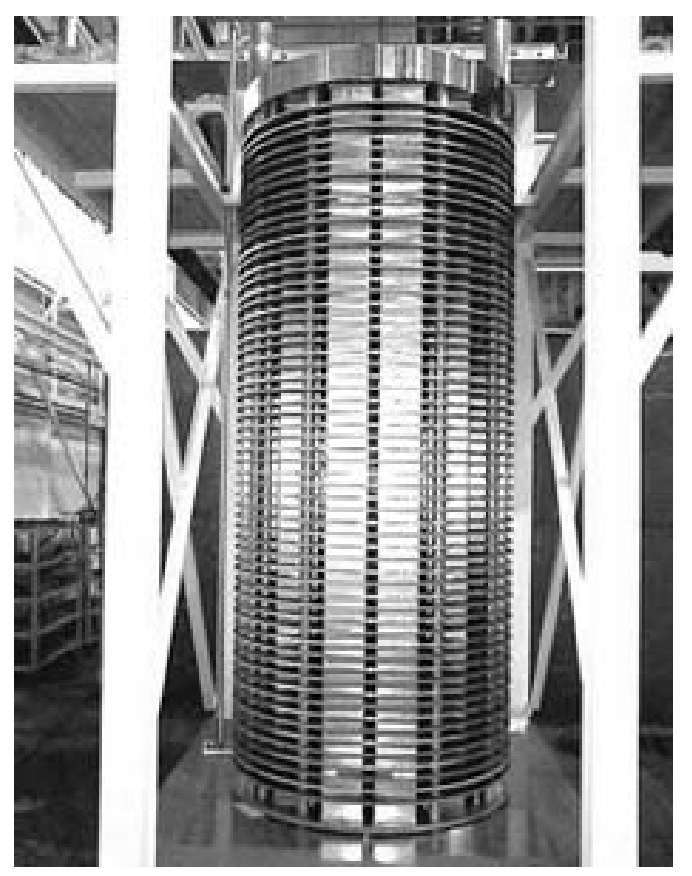

Figura 35 - Cesto para o casco UMS de concreto da NAC para CNQ-PWR. Fonte: NAC (2008)

O casco vertical é de concreto reforçado com barras de aço e revestido internamente por aço carbono, e é oferecido no mercado em cinco tamanhos: altura de $5,36 \mathrm{~m}$ a 5,74m e diâmetro externo de $3,45 \mathrm{~m}$. A massa do maior casco, quando vazio, é de $121.000 \mathrm{~kg}$ e carregado $160.000 \mathrm{~kg}$.

A empresa norte-americana Transnuclear desenvolveu um sistema de cascos de armazenagem conhecido como NUHOMS ${ }^{\circledR}$.

O modelo 24P, o primeiro a ser fabricado pela Transnuclear que prevê a utilização de elementos de $0,216 \mathrm{~m}$ x $0,216 \mathrm{~m}$ e $4,24 \mathrm{~m}$ de comprimento, destina-se ao transporte e armazenagem. O calor máximo de decaimento por elemento CNQ deve ser $0,75 \mathrm{~kW}$, com uma potência de calor máxima de $13,5 \mathrm{~kW}$. O enriquecimento inicial máximo 
do combustível é $3,43 \%$ de ${ }^{235} \mathrm{U}$ e o burnup máximo de $40 \mathrm{GWd} / \mathrm{tU}$. O sistema consiste de um cilindro, um casco de transporte e um módulo de armazenagem horizontal.

Dos três tipos anteriormente citados, um deles pode abrigar 24 elementos CNQ sem as barras de controle, outro 24 elementos CNQ com as barras, e um terceiro 13 elementos de CNQ danificados (IAEA, 2000). Hoje existem quatro tipos de cilindros com as mesmas dimensões externas e são utilizados para o transporte e armazenagem ou só armazenagem de 24 elementos CNQ-PWR e dois para 32 elementos, Tabela 4. Todos os cilindros são de aço inoxidável e depois de carregados, são preenchidos com gás hélio.

Tabela $4-$ Cascos $\mathrm{NUHOMS}^{\circledR}$ apenas para armazenagem e para transporte e armazenagem

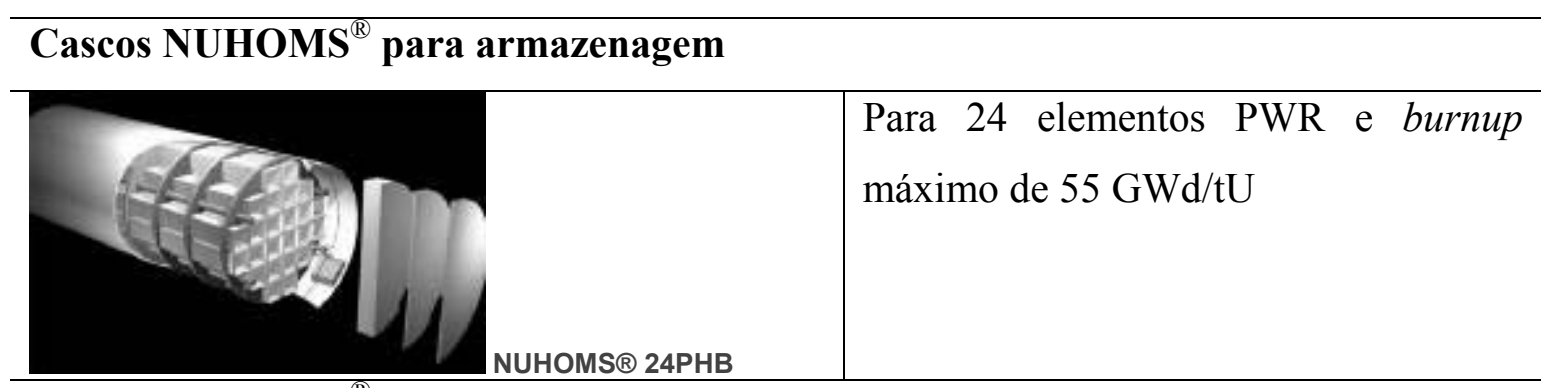

Cascos NUHOMS $^{(\mathbb{R}}$ para transporte e armazenagem

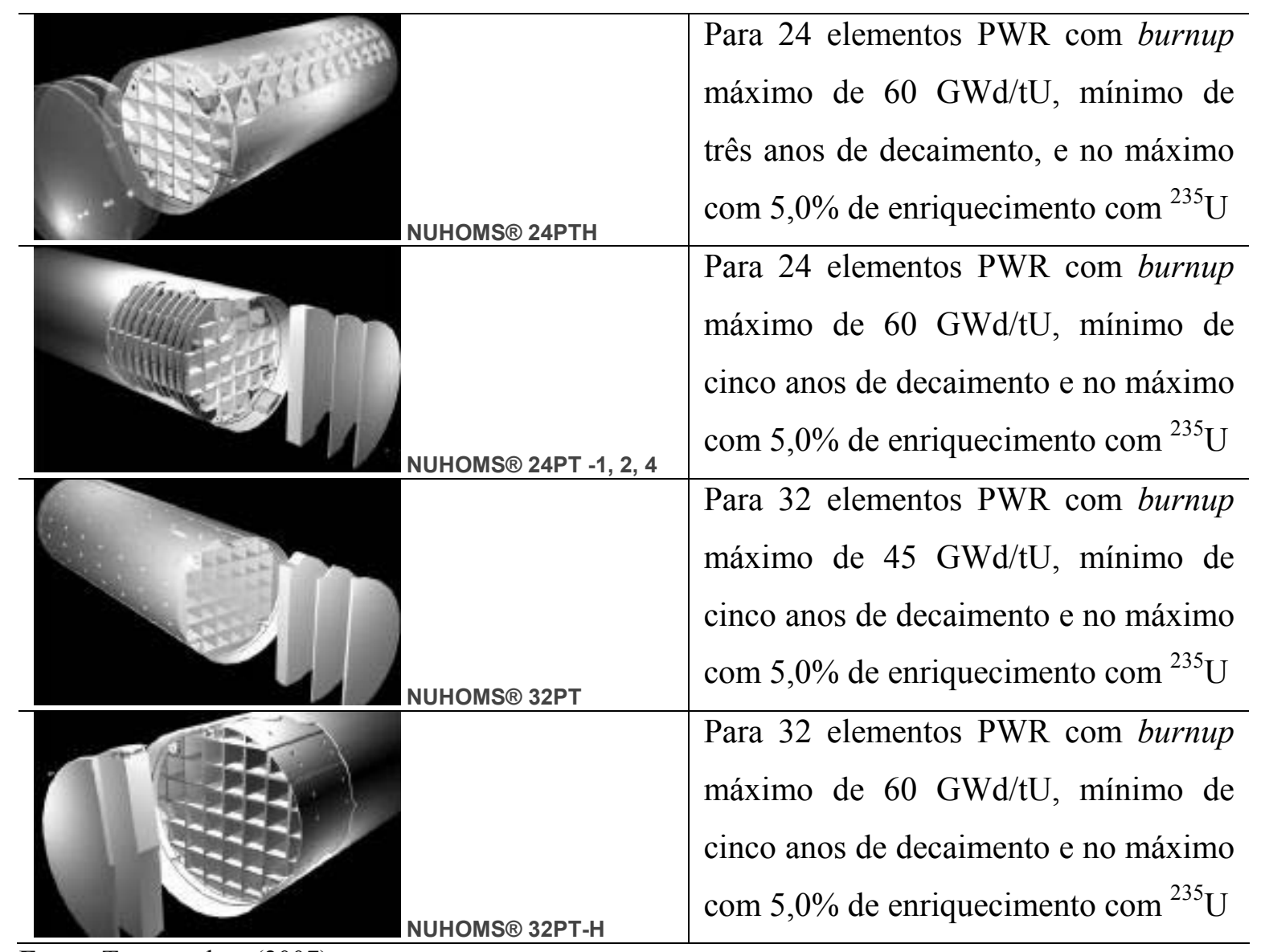

Fonte: Transnuclear (2007) 
O casco de transferência para o sistema $\mathrm{NUHOMS}^{\circledR}$ é constituído por uma carcaça interna e uma externa, ambas de aço, Tabela 5. Entre essas duas carcaças, é utilizado chumbo como blindagem contra radiação gama. A blindagem contra nêutrons está localizada na parte externa ao casco, protegida por um revestimento de aço inoxidável. O casco ainda possui tampas, plugues de dreno e ventilação, êmbolo de extração e vedadores de contenção. Os limitadores de impacto, colocados nas extremidades são confeccionados no formato de uma colméia de alumínio preenchida com espuma de poliuretano. A elevação do casco deve ser realizada por um guincho com capacidade de elevação de $113.000 \mathrm{~kg}$.

Tabela 5 - Cascos NUHOMS ${ }^{\circledR}$ de transferência

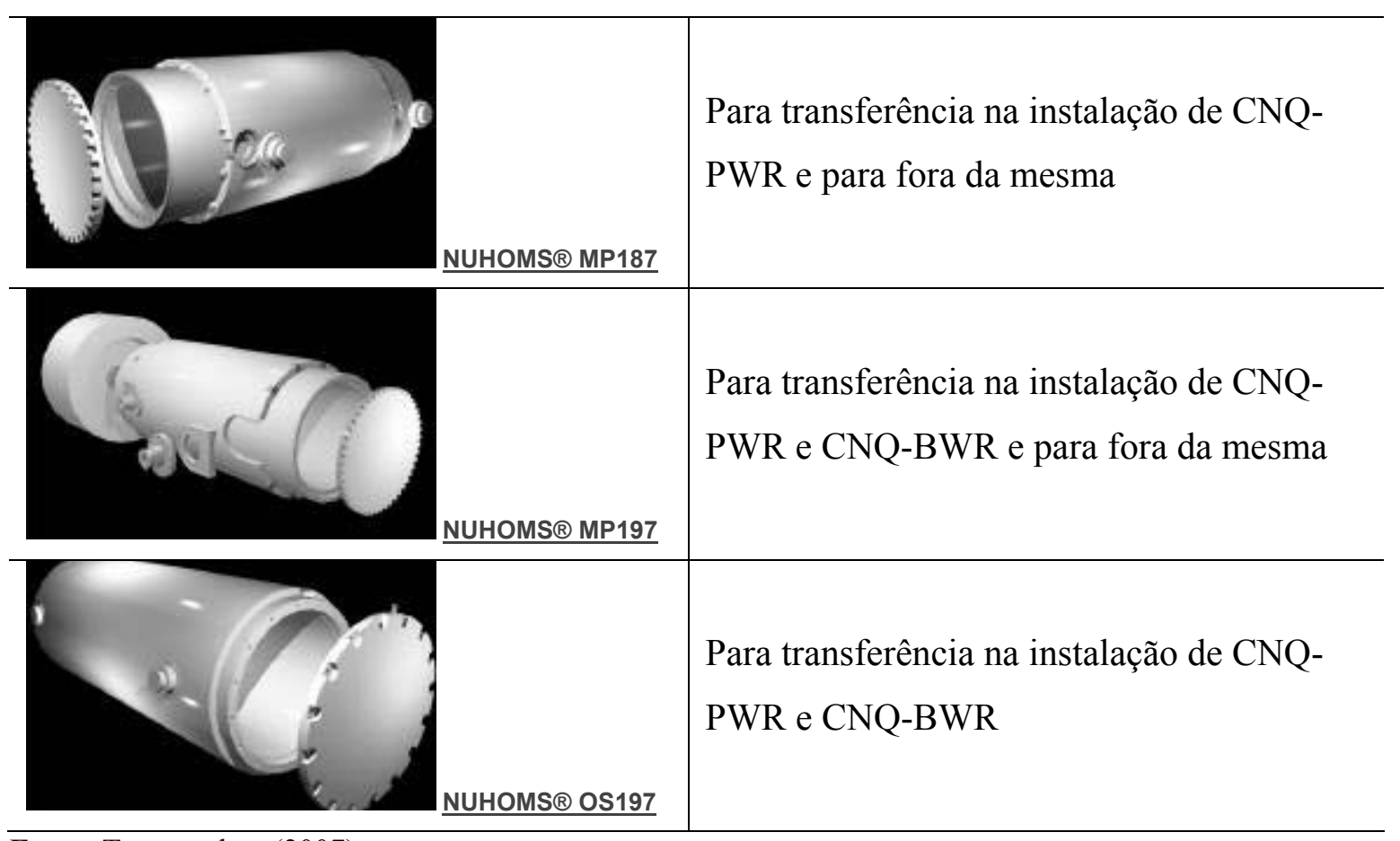

Fonte: Transnuclear (2007)

Os cilindros são armazenados em módulos horizontais de concreto após a transferência do casco de transporte, Figura 36. Essa transferência é realizada por extração do cilindro do interior do casco de transporte por meio de um êmbolo. O módulo de concreto recebe o cilindro na posição horizontal e propicia a blindagem contra nêutrons e raios gama. 


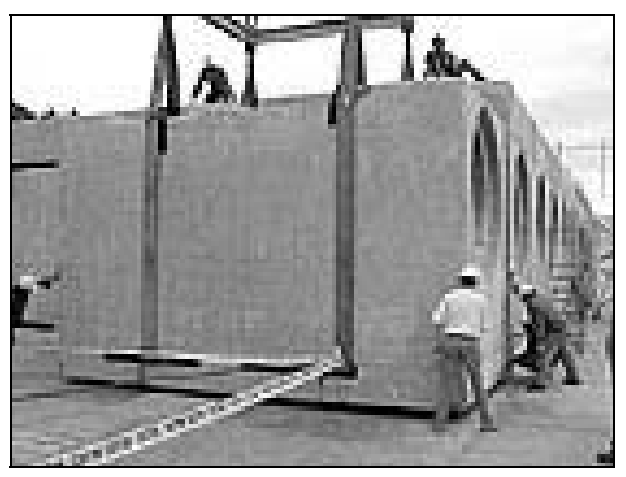

Figura 36 - Armazenagem de cascos NUHOMS ${ }^{\circledR}$ na horizontal.

Fonte: Transnuclear (2007)

A empresa norte-americana BNFL Fuel Systems, subsidiária da BNFL inglesa, projetou o sistema TransStor para 24 elementos CNQ-PWR, com um enriquecimento inicial máximo de $5 \%$ de ${ }^{235} \mathrm{U}$. O burnup máximo aceitável depende do tempo de resfriamento em piscina (IAEA, 2000). Normalmente para um burnup de 30GWd/tU o resfriamento é de cinco anos e para $40 \mathrm{GWd} / \mathrm{tU}$, dez anos. O sistema consiste de um cilindro de aço inoxidável, um casco de armazenagem de concreto e um casco de transporte de chumbo e aço inoxidável. O cilindro incorpora um cesto interno que contem placas com boro para controle da criticalidade. O casco de transporte é construído na forma de um "sanduíche" de aço inoxidável e chumbo, possui blindagem contra nêutrons e limitadores de impacto para usar durante o transporte.

O diâmetro externo do cilindro de aço inoxidável é $1,68 \mathrm{~m}$ e a altura 4,88m. O casco de transporte possui 4,98m de diâmetro externo, 7,49m de altura e massa total de aproximadamente $118.000 \mathrm{~kg}$. O casco de concreto tem diâmetro externo de $3,45 \mathrm{~m}$ e altura $5,72 \mathrm{~m}$.

O cilindro é carregado com CNQ na piscina do reator, transferido para o casco de transporte e depois, novamente transferido para um casco de armazenagem.

França - A empresa francesa Transnucléaire desenvolveu vários modelos de cascos de acordo com o tempo de resfriamento do CNQ e suas características. A capacidade dos cascos varia de 24 e 37 elementos CNQ-PWR.

A Figura 37 mostra diferentes tipos de cascos TN produzidos pela empresa.

O casco modelo TN24, já apresentado na Figura 24, permite transportar e armazenar elementos CNQ com um tempo de resfriamento de 5 a 10 anos e burnup de $33 \mathrm{GWd} / \mathrm{tU}$. 


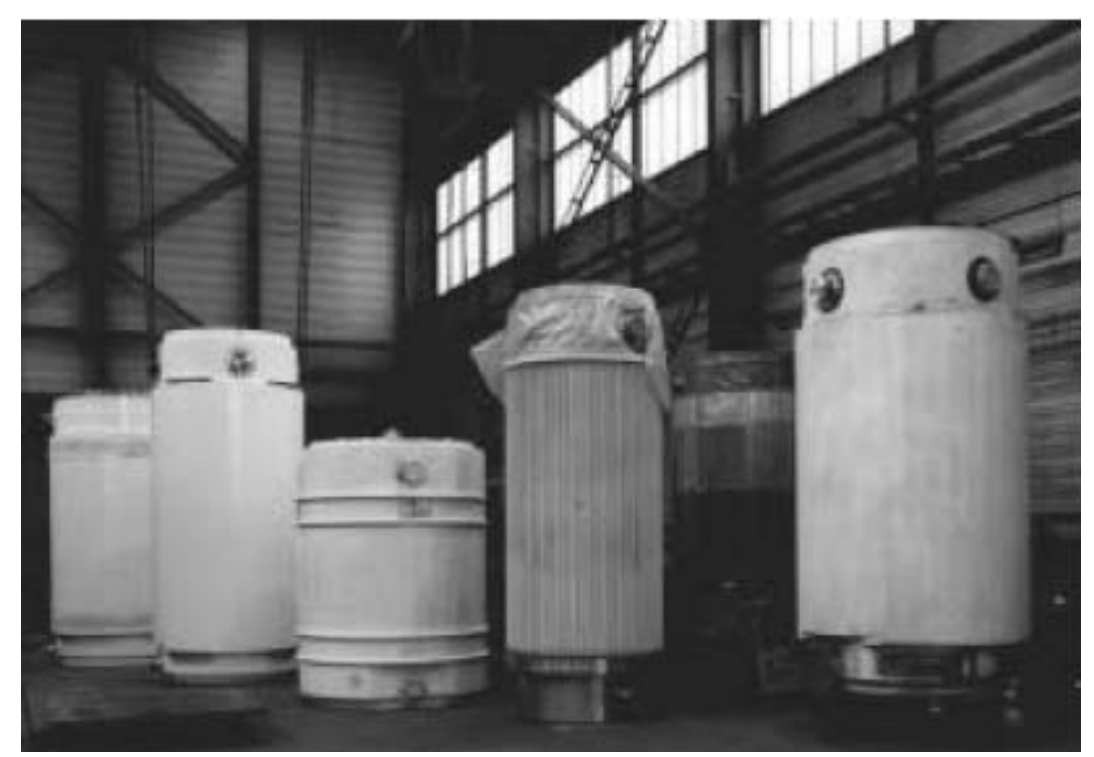

Figura 37 - Diferentes modelos de cascos do tipo TN24 para armazenagem seca na vertical acima do nível do solo, produzidos pela Transnucléaire

Fonte: Roland et al. (2003)

Esse casco é construído por uma parede espessa de aço forjado, que pode variar de $0,22 \mathrm{~m}$ a $0,35 \mathrm{~m}$ de espessura e uma camada externa de resina borada que pode variar de $0,08 \mathrm{~m}$ a $0,18 \mathrm{~m}$ de espessura, com revestimento externo em aço. $\mathrm{O}$ aço forjado e a resina com boro proporcionam blindagem contra radiação gama e nêutrons. Placas longitudinais de cobre, transversais à resina, conectam as paredes de aço forjado, interno, ao revestimento de aço, externo, propiciando a transferência de calor. O casco é manuseado por meio de munhões aparafusados à parede de aço forjado e protegido, nas extremidades, por limitadores de impacto que são retirados para armazenagem vertical sobre piso de concreto. A vedação de cada uma das duas tampas independentes é composta por dois anéis metálicos concêntricos. $\mathrm{O}$ espaço entre os anéis é preenchido com gás hélio pressurizado e continuamente monitorado, de modo a assegurar liberação nula por um período superior a 50 anos. Se desejável, pode ainda ser feita a instalação e soldagem de uma terceira tampa. A cavidade do casco contém um cesto removível que abriga os elementos CNQ. O cesto também proporciona controle da criticalidade, pois as células que acomodam os elementos CNQ são confeccionadas em liga de alumínio com boro.

O casco TN24 é carregado imerso em água da piscina do reator, segundo procedimentos específicos. Após a carga, a água é drenada da cavidade interna, é feita a secagem e o preenchimento com gás inerte. A água no interior do corpo do casco é retirada mediante um dreno na parte inferior do casco. A estanqueidade é assegurada por anéis de vedação metálicos e existem dispositivos para a realização de testes de contenção. Nesse 
sistema, não é necessário abrir o casco nem transferir o CNQ no transporte ou durante a armazenagem. A manutenção durante o período de armazenagem se limita à inspeção visual e re-pintura, quando necessário.

Ucrânia - Um sistema para armazenagem seca de CNQ de reatores tipo VVER 1000 (versão russa dos reatores PWR) na central de Zaporizhzhya, consiste de quatro componentes básicos: cesto de armazenagem, contêiner de elevação, casco de concreto ventilado e equipamentos auxiliares.

O cesto de armazenagem é hermeticamente selado, projetado para arranjo de 24 elementos CNQ-VVER 1000, anteriormente resfriados na piscina anexa ao reator por, no mínimo, cinco anos após o descarregamento.

O contêiner de elevação permite a transferência do cesto de armazenagem para o casco de concreto e assegura a proteção do pessoal contra exposição à radiação. $\mathrm{O}$ casco ventilado permite armazenar o CNQ via seca e assegura que o resfriamento esteja dentro das normas de proteção radiológica. O resfriamento dos elementos é feito por meio da circulação natural do ar no interior do casco de aço que passa entre a superfície externa dos cestos e a superfície interna do casco de concreto.

Os cascos de concreto ventilados (Figura 28) são transportados por veículos especiais até a área de armazenagem temporária localizada dentro dos limites do sítio do reator. As dimensões principais do casco de concreto são: 3,38m de diâmetro externo e $5,81 \mathrm{~m}$ de altura.

Na Tabela 6 é apresentado um resumo comparativo dos cascos apresentados neste tópico.

Tabela 6 - Comparação entre alguns cascos de armazenagem provisória para CNQ-PWR.

\begin{tabular}{ccccccc}
\hline Fabricante & Modelo & $\begin{array}{c}\text { Quanti- } \\
\text { dade de } \\
\text { elementos }\end{array}$ & $\begin{array}{c}\text { Diâmetro } \\
\text { externo } \\
\mathbf{( m )}\end{array}$ & $\begin{array}{c}\text { Altura } \\
\mathbf{( m )}\end{array}$ & $\begin{array}{c}\text { Massa do } \\
\text { casco } \\
\text { carregado } \\
\mathbf{( k g )}\end{array}$ & Material \\
\hline GNS & Castor & vários & vários & vários & vários & metal \\
Holtec & Hi Star & $24 / 32$ & 2,44 & 5,16 & $>112000$ & metal \\
Holtec & Hi Storm & $24 / 32$ & 3,37 & 5,87 & $>162500$ & concreto \\
NAC & STC & 26 & 2,52 & 4,90 & 116000 & metal \\
\hline
\end{tabular}


Continuação da Tabela 6

\begin{tabular}{ccccccc}
\hline NAC & UMS & 24 & 3,45 & 5,74 & 160000 & concreto \\
Transnuclear & NUHOMS & vários & vários & vários & vários & concreto \\
BNFL & TranStor & 24 & 3,45 & 5,72 & $>120000$ & concreto \\
Transnucleaire & TN & vários & vários & vários & vários & metal \\
Zaporizhzhya & - & 24 & 3,38 & 5,81 & - & concreto \\
\hline
\end{tabular}

Fonte: IAEA (2000)

\subsubsection{Previsões para armazenagem de CNQ do futuro tipo de reator EPR}

Para o novo reator de terceira geração, EPR, cujo combustível terá um aumento no burnup e no conteúdo de radionuclídeos, a armazenagem do CNQ deverá ser mais avançada e os cascos deverão possuir melhores capacidades de absorção de nêutrons, blindagem mais robusta, melhor desempenho técnico, resistência estrutural e contenção para manter níveis apropriados de segurança radiológica e física.

As áreas de estudo devem abranger: melhoria dos materiais do cesto interno ao casco, inovações quanto à transferência de calor, desenvolvimento de novos materiais para blindagem de nêutrons e melhoria no desempenho dos absorvedores de impacto (Issard, 2007).

\subsubsection{Ensaios físicos dos cascos}

Para a segurança dos próprios cascos, do meio ambiente e do público que se encontra em rotas de transporte de cascos que seguem para a armazenagem seca ou qualquer outro tipo de armazenagem, é necessário que sejam seguidas, no Brasil, as normas de transporte da CNEN NE-5.01 e, na falta de algum item importante, as normas observadas em outros países e as recomendações, neste aspecto, da IAEA.

Os testes para a qualificação dos cascos podem ser feitos por vários métodos. Podem ser por modelagem em computador, com casco na escala de 1:4 do tamanho real e finalmente, com casco em escala 1:1 - tamanho real (USNRC, 2009; Halstead e Dilger, 2006). Os testes mais importantes e que podem ser feitos no Brasil porque existe experiência neste aspecto e campo de provas (CDTN, Belo Horizonte, MG), referem-se a:

- queda livre: o casco é elevado a $9 \mathrm{~m}$ e solto sobre piso perfeitamente horizontal e resistente; 
- penetração 1: o casco é fixo e um elemento pontiagudo, perpendicular à superfície do casco, é solto sobre o mesmo;

- penetração 2: o casco é solto de um metro de altura sobre elemento pontiagudo, perpendicular à superfície do casco;

- fogo: o casco deve suportar temperaturas altas como as de um incêndio;

- imersão: o casco deve ser submerso sob determinada pressão e deve se manter intacto.

Testes adicionais de certificação podem ser feitos conforme o Federal Institute for Materials Research and Testing - BAM (2009):

- vulnerabilidade: integridade para explosivos e ataques de mísseis;

- imersibilidade: o casco deve poder suportar inundações;

- acidentes em transporte: o casco deve passar por testes de todos os tipos de cenários de transporte.

A experiência quanto aos testes em cascos na proporção 1:1 tem sido desenvolvida nos EUA atendendo a norma 10CFR 71.73, como descrito na seqüência abaixo (USNRC, 2009). Para os cascos nacionais devem também ser atendidas as normas CNEN N:E 5.01.

- queda livre: o casco é solto a 9m de altura sobre superfície horizontal caindo sobre a parte da superfície do casco na qual se espera o maior dano. Halstead e Dilger (2006) citam que em testes que mimetizam condições de acidentes hipotéticos, no teste de queda livre a velocidade de choque esperada, com uma coluna de ponte rodoviária, é de 30 milhas $/ \mathrm{h}(13,4 \mathrm{~m} / \mathrm{s})$ equivalente a um impacto de 55-60 milhas $/ \mathrm{h}(24,2-26,8 \mathrm{~m} / \mathrm{s})$. O local mais frágil seria a quina da tampa no limitador de impactos;

- penetração: queda livre do casco de $1 \mathrm{~m}$ de altura sobre uma barra de aço cilíndrica com $15 \mathrm{~cm}$ de diâmetro, que se encontra na posição vertical à superfície horizontal do solo. $\mathrm{O}$ comprimento da barra deve ser suficiente para causar um dano máximo ao casco. $\mathrm{O}$ casco deve ser solto sobre a barra na posição de dano máximo. Dependendo do formato do casco esta deverá ser uma queda de modo que a blindagem contra nêutrons e radiação gama ou o limitador de impacto tenham maior possibilidade de serem danificados;

- resistência térmica: o casco deve estar envolto em fogo de combustível de hidrocarboneto sob temperatura de $800^{\circ} \mathrm{C}$ durante $30 \mathrm{~min}$;

- imersão: o casco deve ser imerso sob água a $0,9 \mathrm{~m}$ em situação em que se espera vazamento máximo 


\subsubsection{Identificação e rastreabilidade dos cascos contendo CNQ}

O CNQ armazenado deve ser rigorosamente identificado e um método, preconizado pela IAEA (2003 e 2006a), estabelece:

- Dados do combustível: tipo, histórico de potência, conteúdo físsil inicial, burnup e tempo de resfriamento.

○ Outros detalhes do elemento combustível podem ser: presença de absorvedores, dimensões, materiais, características dos elementos e desenhos técnicos/diagramas dos elementos.

- Deve ser especificada a massa inicial do U total presente no elemento combustível, bem como a composição isotópica inicial.

- Os dados de irradiação do elemento devem ser registrados de modo que possibilitem cálculos futuros e para que se tenha o conhecimento do histórico do CNQ durante toda sua vida no reator. Essas informações são: data de recebimento do elemento combustível do fabricante, local de armazenagem do elemento não queimado, data do primeiro carregamento no núcleo do reator, posição no núcleo, primeiro descarregamento, posição e carregamentos posteriores, data do descarregamento final. Nesse período deve ser registrado também se o elemento foi danificado, reparado, etc.

- Para o cálculo estimado do inventário dos produtos de físsão gerados no CNQ é necessário determinar o burnup acumulado no período, além do histórico de potência.

- Atividade: atividades dos principais radionuclídeos emissores $\alpha, \beta, \gamma$ e taxa de emissão de nêutrons.

- Segurança contra a criticalidade: configuração geométrica, concentração e inventário do material físsil contido no CNQ $\left({ }^{233} \mathrm{U},{ }^{235} \mathrm{U},{ }^{239} \mathrm{Pu},{ }^{241} \mathrm{Pu}\right.$, por exemplo), presença de absorvedores de nêutrons e demonstração da não-criticalidade.

- Taxa de dose: taxa de dose para nêutrons e raios- $\gamma$ na superfície externa do casco e a $1 \mathrm{~m}$ de distância.

- Contaminação superficial: níveis de contaminação $\alpha, \beta$ e $\gamma$. 
- Propriedades térmicas: potência térmica, condutividade térmica, temperatura máxima prevista para o CNQ armazenado e temperatura externa na superfície do casco.

- Massa do CNQ e do casco: massa total.

- Qualidade do casco: especificação dos materiais do casco, tara, dimensões, resistência à corrosão, qualidade da soldagem, certificados dos materiais utilizados, registros de qualidade do processo de fabricação.

- Dados de manuseio e transportabilidade: resultados dos testes de queda, testes de estanqueidade, requisitos de transporte e elevação.

- Identificação do casco: permanente e única.

\subsection{Instalações de armazenagem seca}

Neste tópico, são apresentadas as principais instalações de armazenagem temporária para CNQ de reatores PWR, proteção física e as vantagens das instalações de armazenagem seca em relação à úmida.

\subsubsection{Instalações de armazenagem provisória de CNQ existentes no mundo}

Existem vários tipos de instalações de armazenagem para CNQ em cascos que podem ser armazenados na vertical ou na horizontal, em instalações cobertas ou a céu aberto. Em instalações cobertas, por exemplo, existem diversas formas de armazenagem entre elas em poços, como pode ser visto na Figura 38. Neste aspecto, no Japão, são realizados estudos arquitetônicos para diversos modelos de instalação de armazenagem para CNQ (Shirai et al., 2003), como mostra a Figura 39. Para outros países, não abrangidos neste trabalho, podem ser consultados relatórios específicos, como por exemplo, Kulnarni et al (2003), Takáts e Buday (2003) e Solignac et al (2007). 

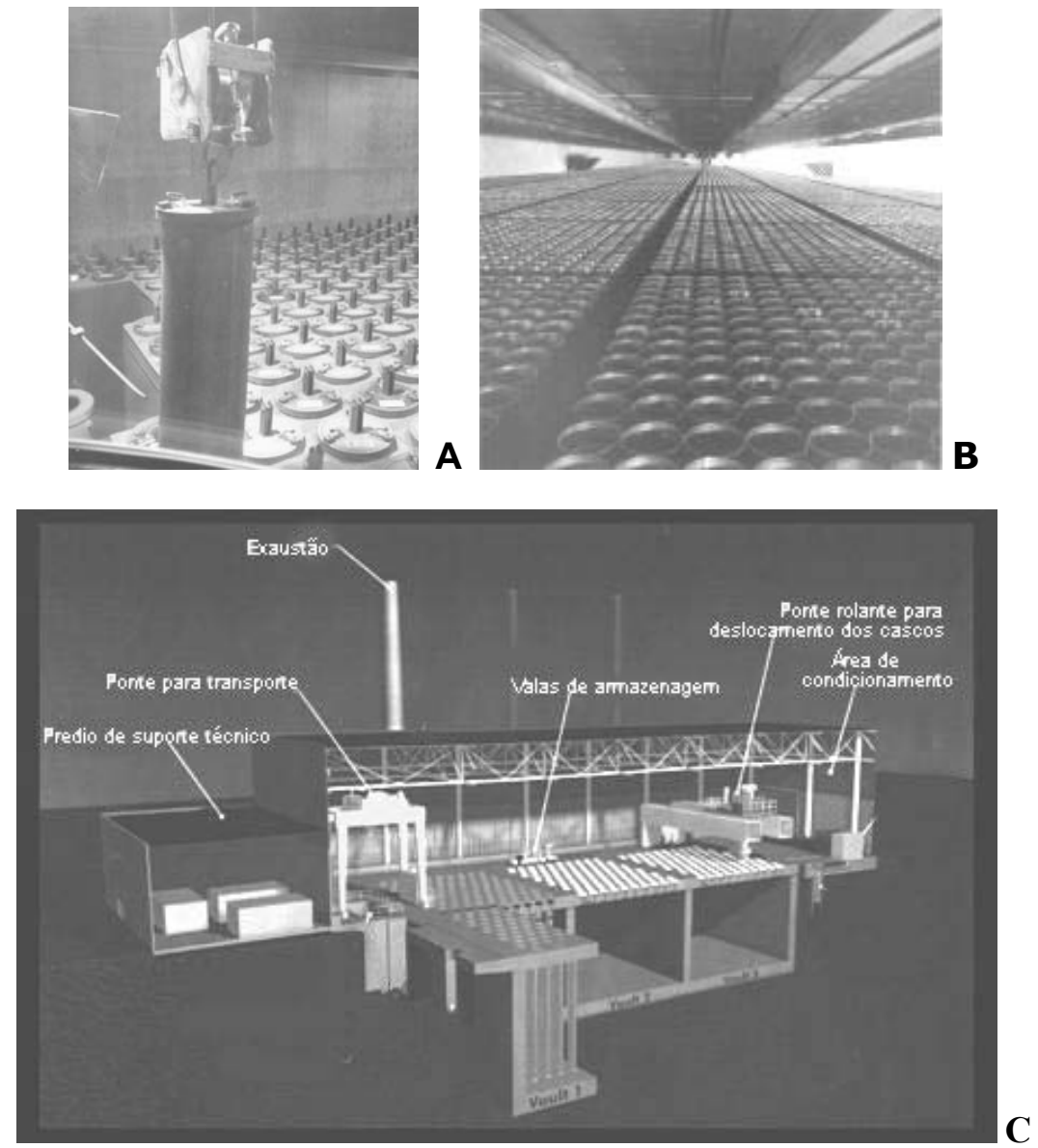

Figura 38 - Exemplo de armazenagem seca para CNQ em poços em: (A) Idaho, EUA, refrigerada a ar, (B) Wylfa, Inglaterra, semelhante a da Hungria pela mesma companhia BNS Nuclear Services, (C) Hanford, EUA.

Fonte: (A) INL, 2009; (B) Babcock, 2009; (C) Qmetrics, 2009

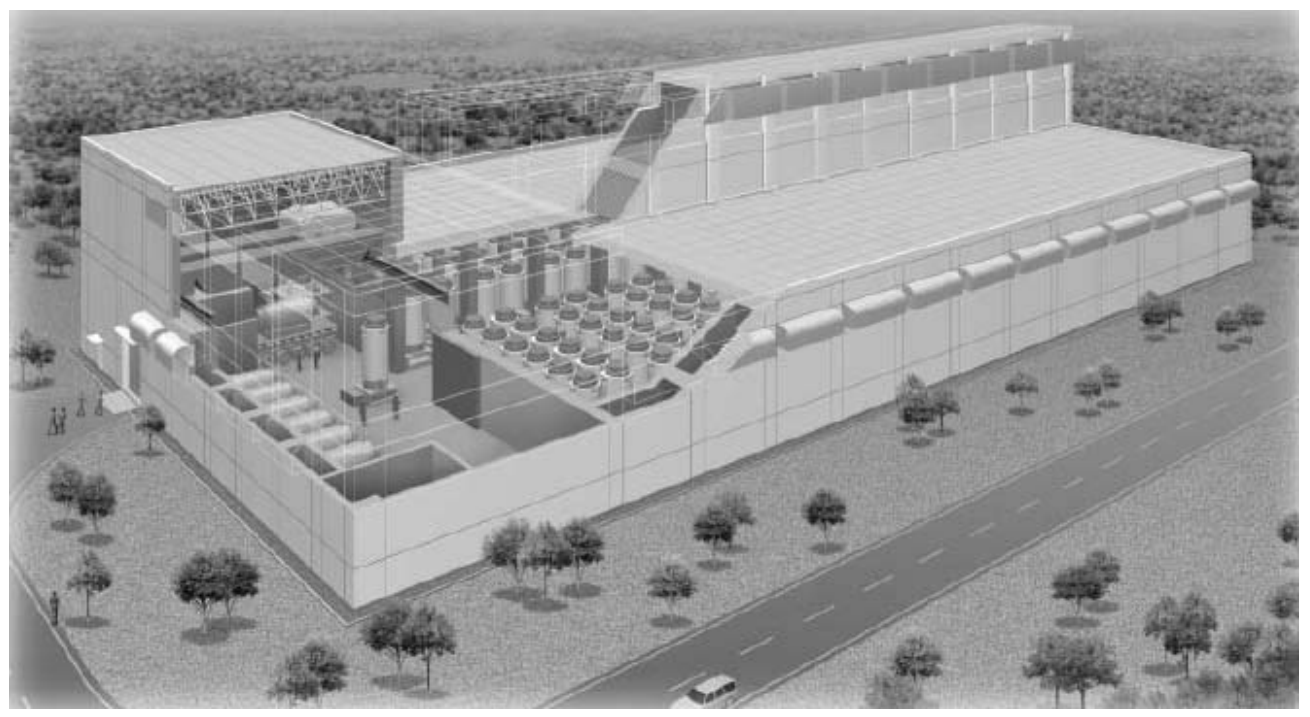

Figura 39 - Exemplo de planta arquitetônica de uma instalação de armazenagem seca de CNQ em cascos, sugerida pelo Japão.

Fonte: Shirai et al (2003) 
$\mathrm{Na}$ Tabela 7 são apresentadas exemplos de instalações comerciais de armazenagem seca provisória de CNQ para combustíveis gerados em reatores PWR.

Tabela 7 - Instalações de armazenagem provisória seca comercial para CNQ-PWR.

\begin{tabular}{|c|c|c|c|}
\hline País & Instalação & Situação & Escala \\
\hline Alemanha & Ahaus Central Interim Storage & Em operação & Comercial \\
\hline Alemanha & $\begin{array}{l}\text { Biblis NPP, Brennelement-Zwischenlager } 1400 \\
\text { tHM }\end{array}$ & Em construção & Comercial \\
\hline Alemanha & Biblis NPP, Interimslager 280 tHM & Em operação & Comercial \\
\hline Alemanha & $\begin{array}{l}\text { Brokdorf On-Site Storage Facility - capac. } 100 \\
\text { cascos }-1000 \text { tHM }\end{array}$ & Em construção & Comercial \\
\hline Alemanha & Brunsbüttel NPP - Interimslager 140 tHM & Aguardando licença & Comercial \\
\hline Alemanha & $\begin{array}{l}\text { Brunsbüttel NPP - Standort-Zwischenlager } 450 \\
\text { tHM }\end{array}$ & Em construção & Comercial \\
\hline Alemanha & Gorleben Central Interim Storage 3800 tHM & Em operação & Comercial \\
\hline Alemanha & $\begin{array}{l}\text { Grafenrheinfeld NPP - Capac. } 88 \text { cascos }-800 \\
\text { tHM }\end{array}$ & Em construção & Comercial \\
\hline Alemanha & Greifswald NPP - Dry Storage - VVER & Em operação & Comercial \\
\hline Alemanha & $\begin{array}{l}\text { Grohnde NPP - Standort-Zwischenlager } \\
\text { capac. } 100 \text { cascos - } 1000 \text { tHM }\end{array}$ & Em construção & Comercial \\
\hline Alemanha & $\begin{array}{l}\text { Gundremmingen NPP - Standort-Zwischenlager } \\
2250 \text { tHM }\end{array}$ & Em construção & Comercial \\
\hline Alemanha & Isar NPP - capac. 152 cascos - 1500 tHM & Em construção & Comercial \\
\hline Alemanha & Jülich Research Center - 8 tHM & Em operação & Comercial \\
\hline Alemanha & Krümmel NPP - Interimslager 120 tHM & Em construção & Comercial \\
\hline Alemanha & Krümmel NPP - Standort-Zwischenlager 800 tHM & Em construção & Comercial \\
\hline Alemanha & Lingen NPP - Standort-Zwischenlager 1250 tHM & Em operação & Comercial \\
\hline Alemanha & Neckarwestheim NPP - 1600 tHM PWR & Em construção & Comercial \\
\hline Alemanha & Philippsburg NPP 1600 tHM PWR & Em construção & Comercial \\
\hline Armênia & Metzamor NPP 74 tHM Dry NUHOMS VVER & Em operação & Comercial \\
\hline Bélgica & Doel NPP 2100 tHM PWR & Em operação & Comercial \\
\hline Coréia & Korea ISFSF 2000 tHM PWR & Planejada & Comercial \\
\hline Eslováquia & Mochovce NPP - SFSF 780 tHM - SF VVER-440 & Planejada & Comercial \\
\hline Espanha & Trillo NPP - capac. 1680 elementos. & Em operação & Comercial \\
\hline EUA & Arkansas Nuclear \#1 \& 2 NPP - ISFSI - PWR & Em operação & Comercial \\
\hline EUA & Calvert Cliffs NPP 1112 tHM - PWR & Em operação & Comercial \\
\hline EUA & Davis Besse NPP - ISFSI 360 tHM - PWR & Em operação & Comercial \\
\hline EUA & H.B. Robinson NPP - ISFSI - 26 tHM - PWR & Em operação & Comercial \\
\hline EUA & McGuire NPP - PWR & Em operação & Comercial \\
\hline EUA & North Anna NPP - ISFSI 840 tHM -Dry TN-32 & Em operação & Comercial \\
\hline EUA & Oconee NPP - 380 tHM - Dry NUHOMS-24P & Em operação & Comercial \\
\hline EUA & Palisades NPP - ISFSI 233 tHM & Em operação & Comercial \\
\hline EUA & Point Beach NPP - ISFSI 447 tHM & Em operação & Comercial \\
\hline EUA & Prairie Island NPP - ISFSI 724 tHM & Em operação & Comercial \\
\hline EUA & Surry NPP - ISFSI 808 tHM & Em operação & Comercial \\
\hline EUA & Private Fuel Storage - 40000 tHM & Planejada & Comercial \\
\hline
\end{tabular}


Continuação da Tabela 7

\begin{tabular}{c|l|c|c}
\hline \multirow{2}{*}{ EUA } & $\begin{array}{l}\text { TMI-2, Debris at Idaho 130 tHM } \\
\text { Dry NUHOMS for TMI-2 SNF }\end{array}$ & Em operação & Comercial \\
\hline EUA & $\begin{array}{l}\text { Trojan NPP - ISFSI 359 tHM (reator } \\
\text { descomissionado) }\end{array}$ & Em operação & Comercial \\
\hline Hungria & Paks NPP - ISFSF 580 tHM & Em operação & Comercial \\
\hline República Checa & Dukovany NPP - ISFSF 600 tHM VVER & Em operação & Comercial \\
\hline República Checa & Dukovany NPP - SFSF 1340 tHM VVER & Comissionamento & Comercial \\
\hline República Checa & Temelin NPP - SFSF 1370 tHM VVER & Em estudo & Comercial \\
\hline Suíça & ZWIBEZ 600 tHM & Em construção & Comercial \\
\hline Suíça & ZWILAG 2500 tHM & Em operação & Comercial \\
\hline Ucrânia & Zaporizhzhya NPP capac. 9120 elementos VVER & Em operação & Comercial \\
\hline \hline
\end{tabular}

Fonte -Adaptado de Integrated Nuclear Fuel Cycle Information System (2008)

As instalações de armazenagem de CNQ, citados na Tabela 7, apresentam uma diversidade de características quanto aos sítios. Algumas dessas características, para instalações de armazenagem seca em cascos, em alguns dos países citados acima, são mostradas a seguir.

\section{$\underline{\text { Alemanha }}$}

A Alemanha possui duas instalações centralizadas (Gorleben e Ahaus) e outras duas na própria instalação dos reatores (Greifswald-Nord e Obrigheim), para armazenagem de CNQ, além das piscinas internas de resfriamento.

Nas instalações de Gorleben, Ahaus e Greifswald, o combustível queimado é armazenado em cascos metálicos. De acordo com a IAEA (2001) e Lidskog e Andersson (2002), a instalação de Gorleben possui uma capacidade para armazenar 3.800ton de CNQ, a de Ahaus 3.960ton e a de Greifswald 560ton.

Nas Figuras 40 e 41 são apresentadas fotos da instalação coberta de armazenagem temporária de Gorleben. 


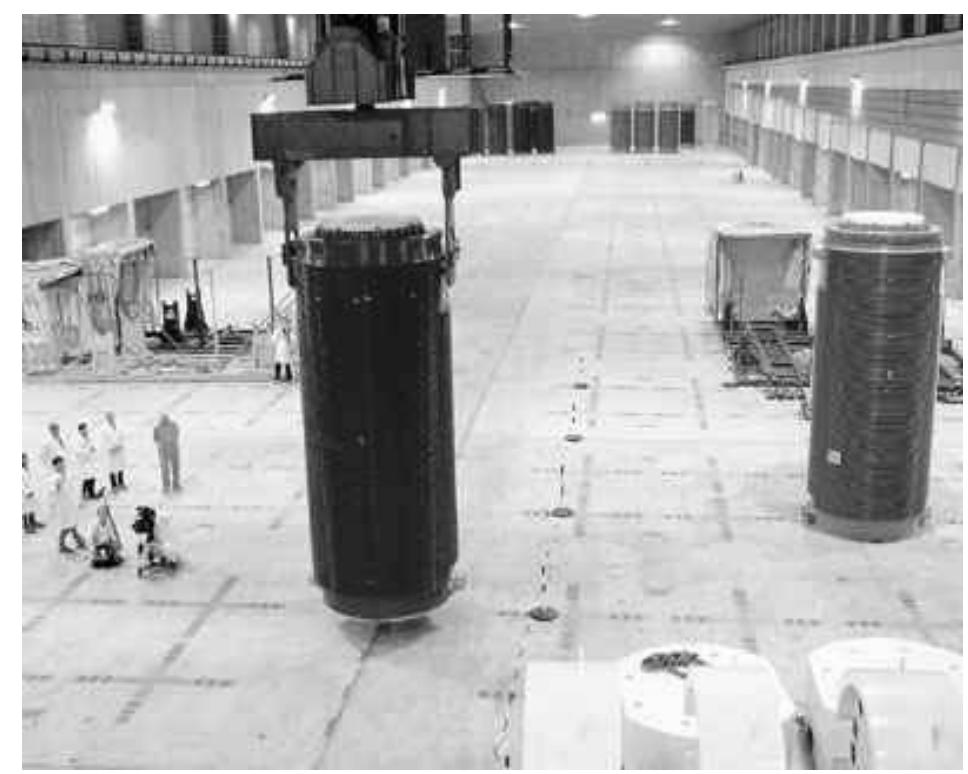

Figura 40 - Interior da instalação de Gorleben, na qual podem ser vistos os cascos de armazenagem de CNQ.

Fonte: GNS (2007)

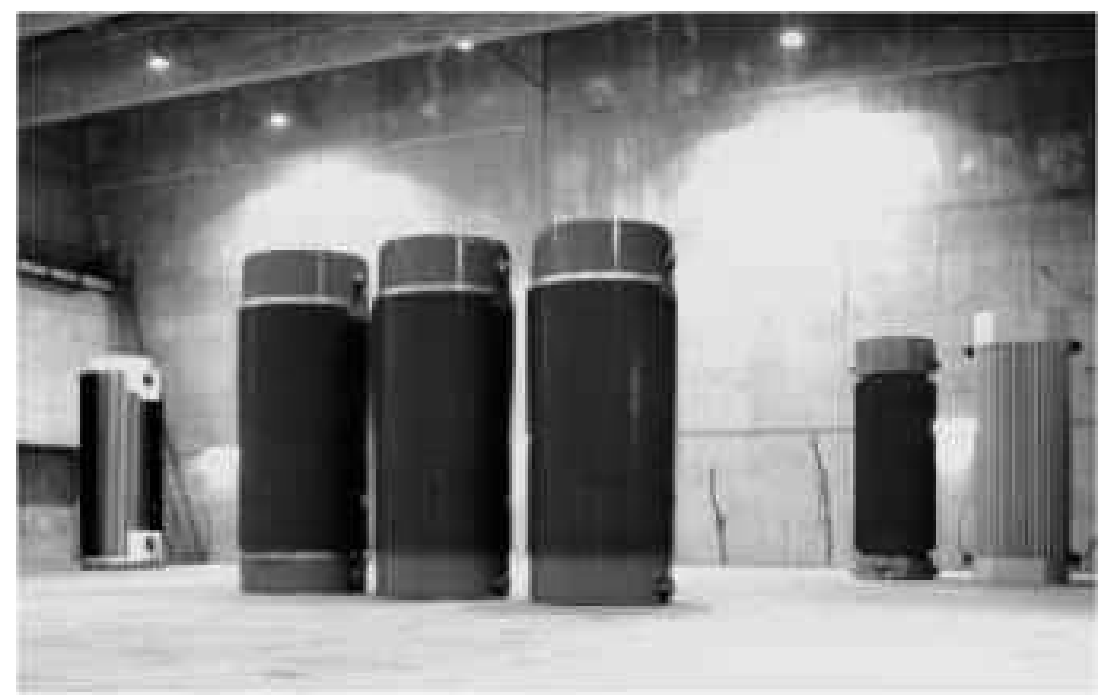

Figura 41 - Cascos metálicos de armazenagem seca de CNQ - Gorleben, Alemanha. Fonte: GNS (2007)

\section{Espanha}

Para o CNQ da central nuclear de Trillo - Espanha, em 2000, foi construído um edifício de armazenagem de cascos metálicos de duplo propósito. Essa instalação com dimensões $80,8 \mathrm{~m} \times 43,5 \mathrm{~m} \times 21,7 \mathrm{~m}$, de concreto reforçado, pode receber 80 cascos de armazenagem colocados na posição vertical.

O edifício resiste a sismos, possui sistema de remoção do calor por meio de convecção natural, tem uma taxa de exposição na superfície externa ao edifício muito 
baixa $(<1 \mu \mathrm{Sv} / \mathrm{h})$, permite fácil manuseio e remoção dos cascos por meio de ponte rolante e possui controle permanente contra eventuais vazamentos dos cascos.

As Figuras 42 e 43 mostram, respectivamente, a planta baixa e um corte lateral do edifício (Martinez e Gago, 2003). Cada casco pode armazenar 21 elementos originários de reator PWR com um burnup máximo de $40 \mathrm{GWd} / \mathrm{tU}$, enriquecimento inicial de $4 \%{ }^{235} \mathrm{U}$ e, no mínimo, 5 anos de resfriamento (IAEA, 2003; Ministério de Indústria y Energia, 1999).

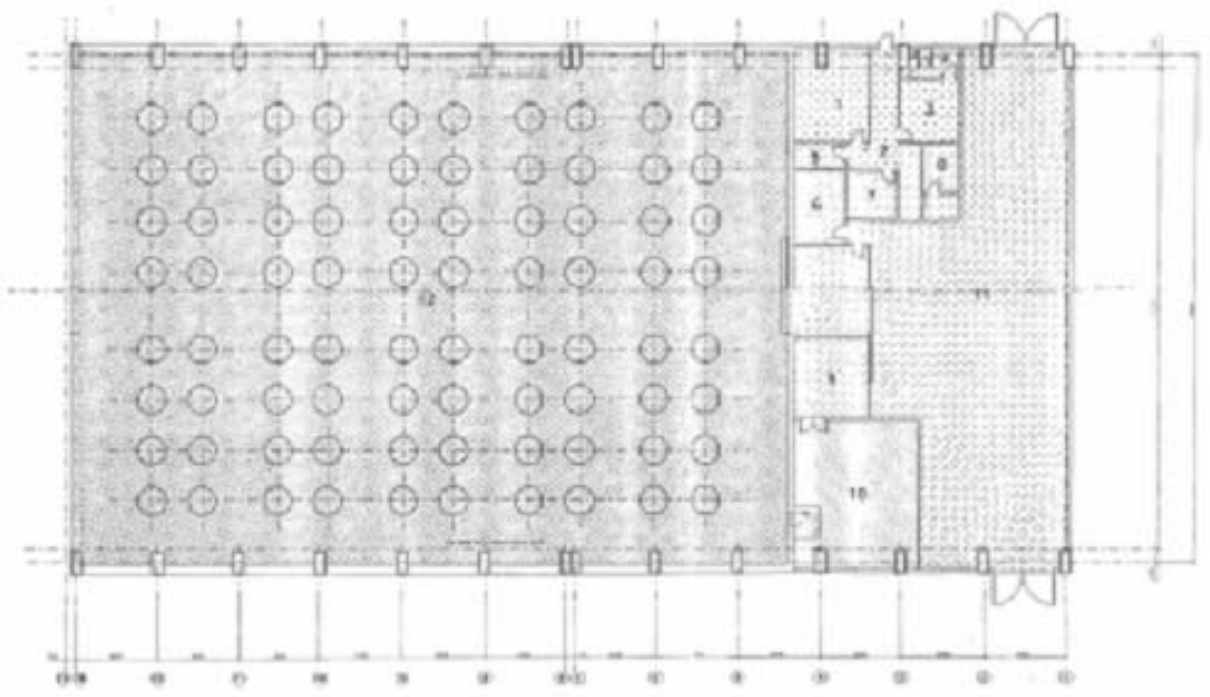

Figura 42 - Planta da instalação de CNQ de Trillo, Espanha.

Fonte: Martinez e Gago, 2003

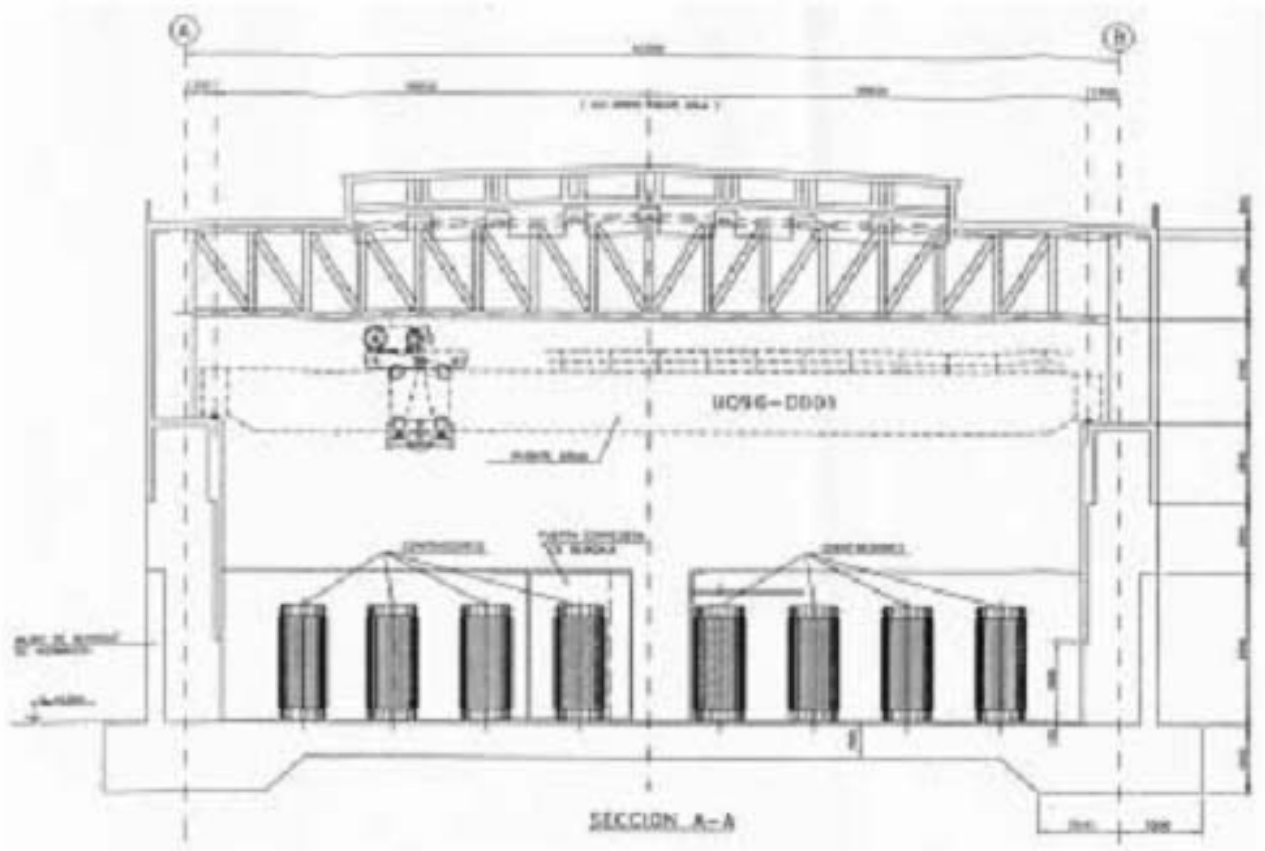

Figura 43- Corte lateral da instalação de CNQ de Trillo, Espanha.

Fonte: Martinez e Gago, 2003 


\section{Estados Unidos}

Até o final de 1998, aproximadamente 38.400ton de combustível nuclear queimado estavam armazenadas nos EUA. A maior parte desse combustível, 37.632ton (98\%), estava armazenada nas piscinas dos reatores. Apenas 1.511ton (2\%) estavam armazenadas em cascos metálicos ou de concreto, nas instalações das centrais nucleares.

Hoje, o país está em fase de licenciamento de vários tipos de cascos que serão colocados em 16 locais para armazenagem de CNQ-PWR (Figura 44) chamados Independent Spent Fuel Storage Installation (ISFSI) (Indian Point, 2008). Nessas instalações, sem cobertura física, os cascos são colocados sobre um piso de concreto reforçado. Atualmente os EUA possuem 55 locais de armazenagem de CNQ em todo o território nacional, 40 locais com licença genérica e 15 com licença especial (USNRC, 2007a).

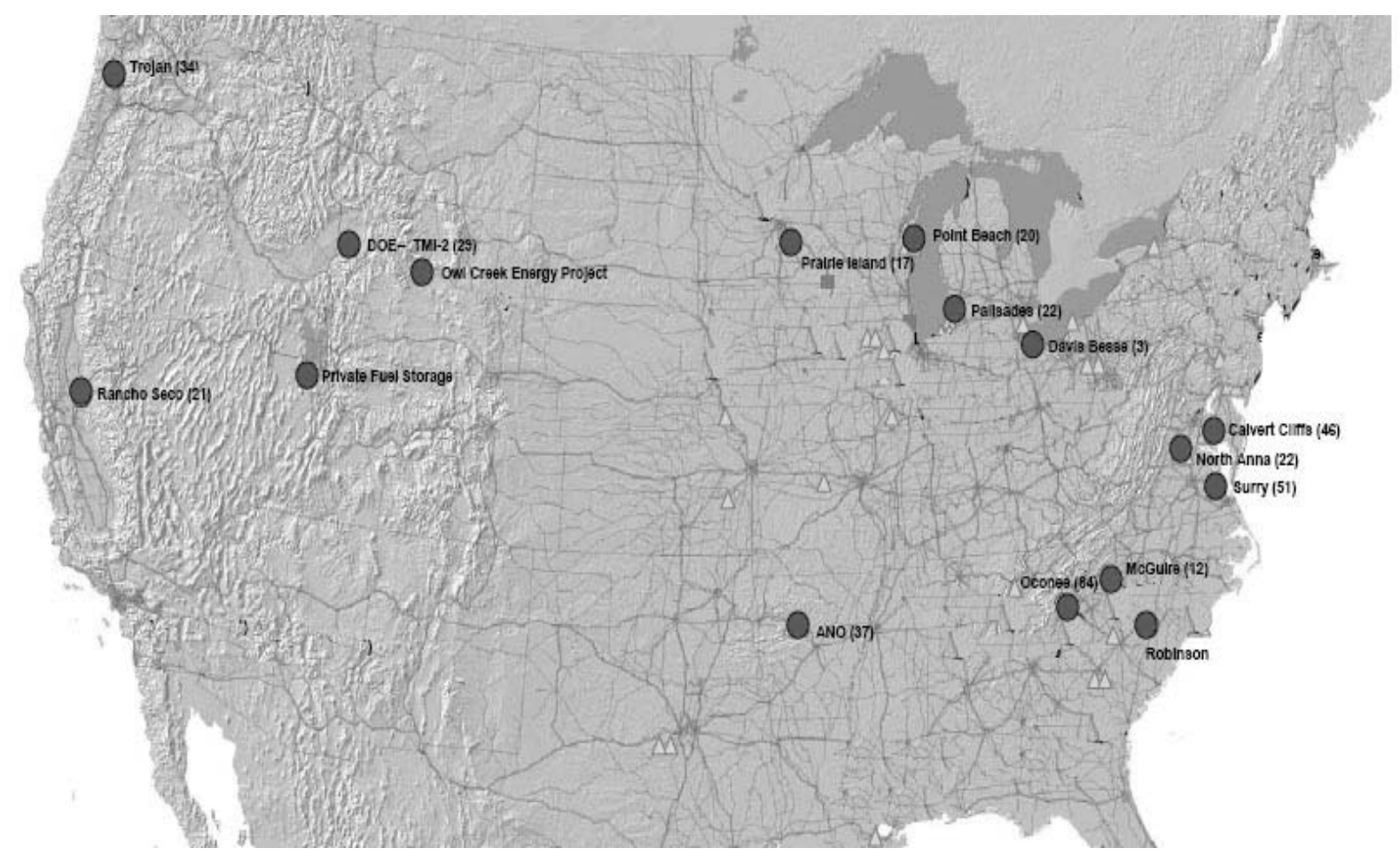

Figura 44 - Localização de 16 instalações de armazenagem provisória de CNQ-PWR no território dos EUA.

Fonte: Adaptado de Spent Fuel News (2005)

Nas Figuras 45, 46 e 47 podem ser observadas as instalações de armazenagem seca de Surry, Palisades e Calvert Cliffs, EUA. Na instalação de Calvert Cliffs é possível armazenar os cascos na posição horizontal. 


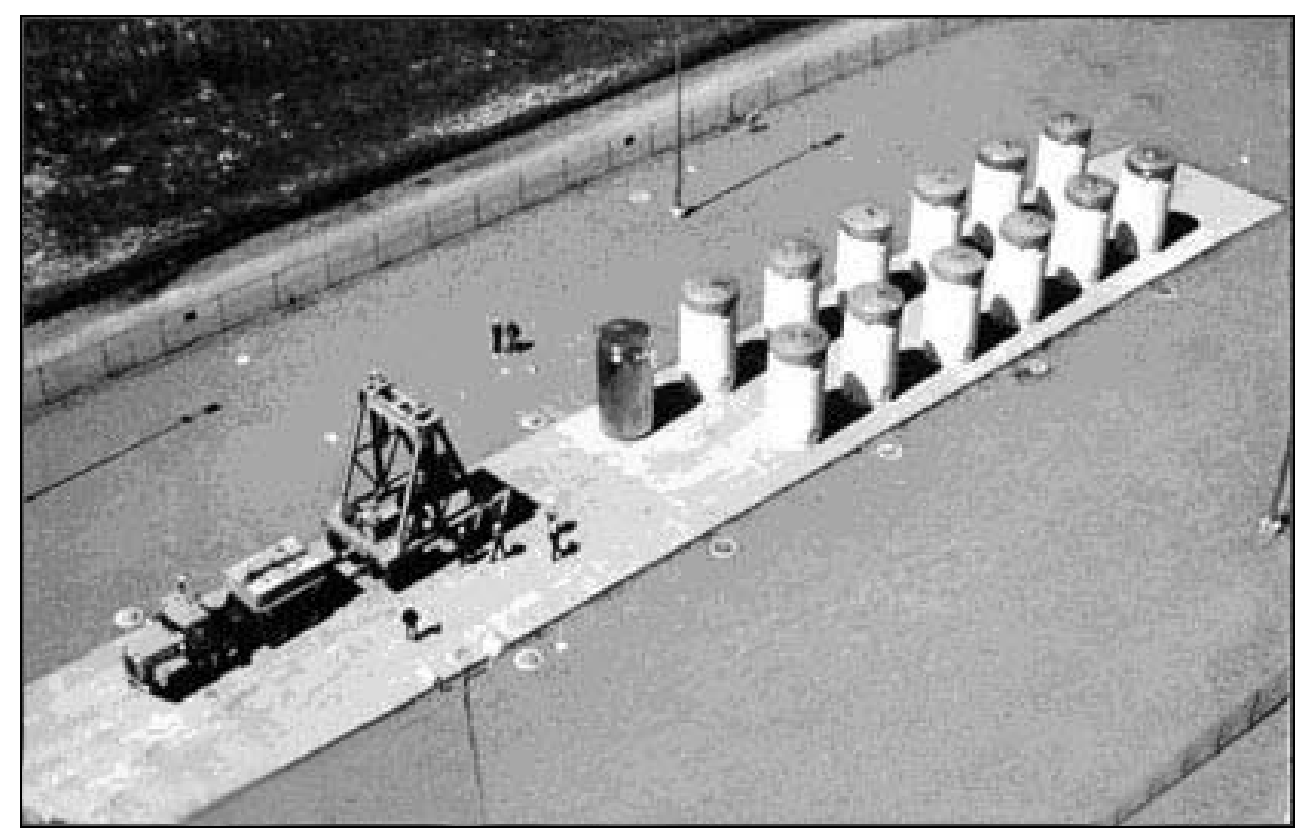

Figura 45 - Instalação de armazenagem temporária de Surry - EUA. Fonte: Downwinders (2006)

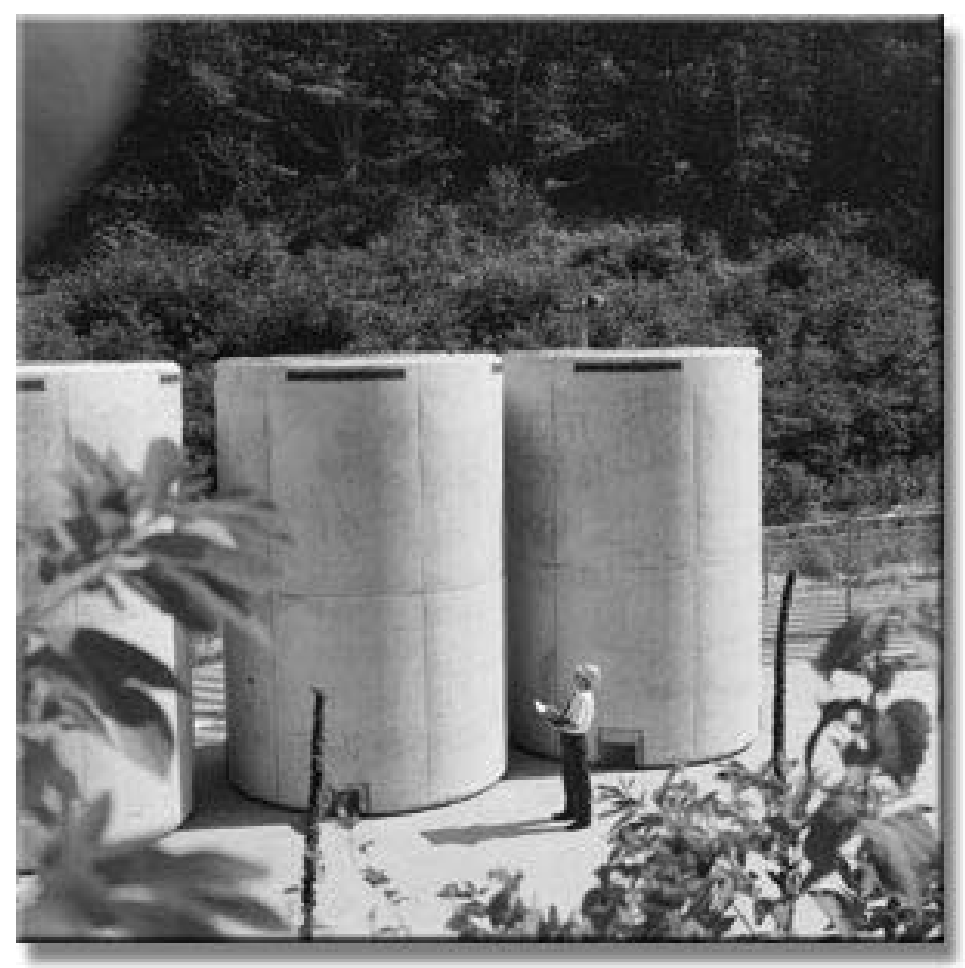

Figura 46 - Instalação de armazenagem temporária de Palisades - EUA. Fonte: BNG, 2009 


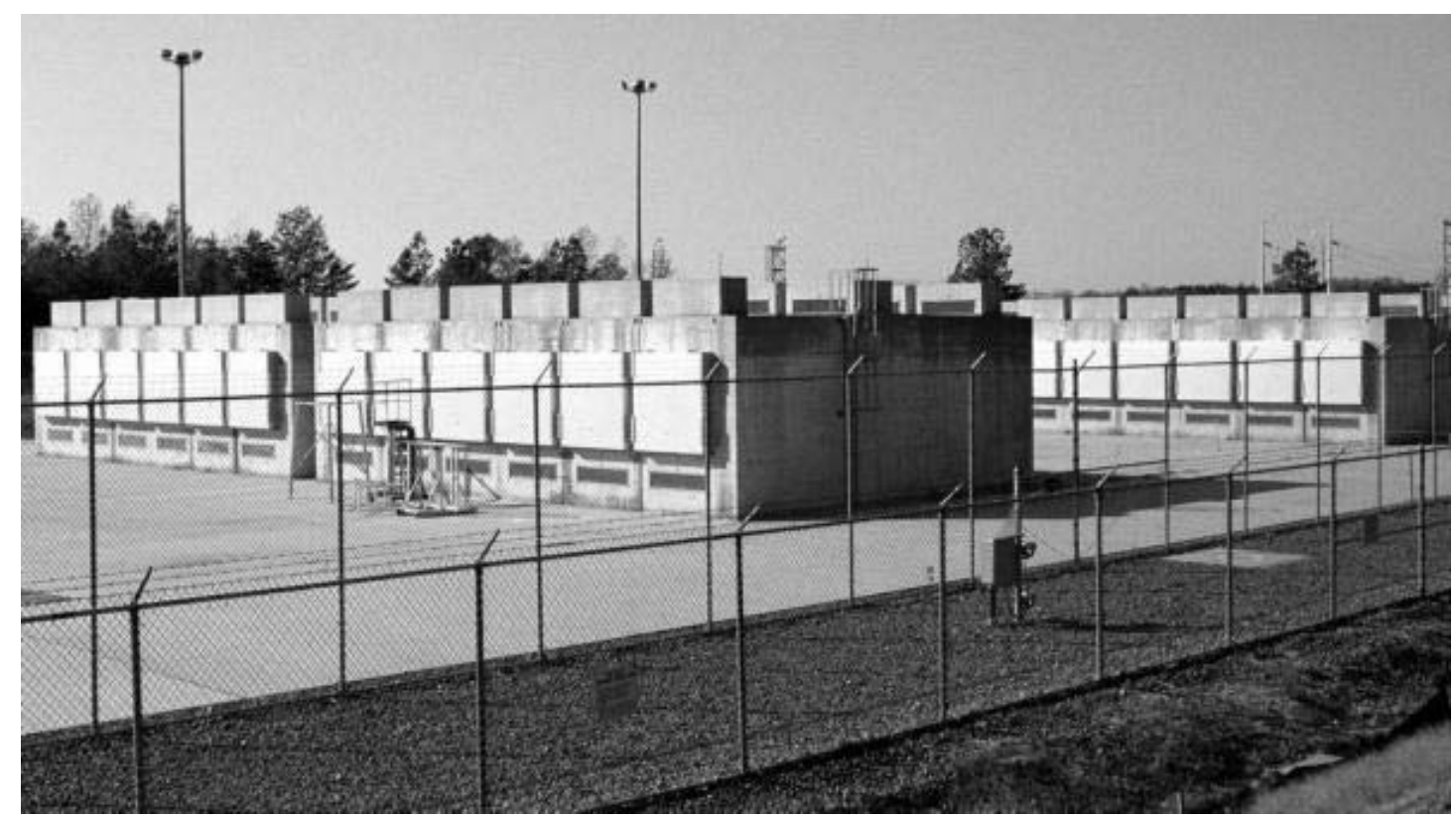

Figura 47 - Instalação de Calvert Cliffs - EUA de armazenagem seca temporária de cascos na posição horizontal.

Fonte: L.A. Sun, 2009

\section{$\underline{\text { República Checa }}$}

Conforme relatório da IAEA (2002), o CNQ gerado nas usinas da República Checa é armazenado temporariamente em via seca por 60 anos, em cascos de aço. Está localizada no mesmo local da central de Dukovany. Existe uma instalação para acomodar 60 cascos, totalizando 600ton de CNQ, com planos de expansão para 1.340ton e construção de outra instalação com capacidade para 1.370ton. Os cascos metálicos utilizados são do tipo CASTOR (IAEA,1999a)

A instalação de armazenagem temporária de CNQ recebe o combustível que, após resfriamento em piscinas entre 6 e 7,5 anos, é armazenado por um período de 60 anos. Acredita-se que o tempo previsto para armazenagem seja necessário para a construção de um repositório geológico (Lietava et al., 2003).

A proposta da nova instalação de armazenagem seca, situada na central Temelin, tem o início das operações previsto para 2014 (Coufal; Brzobohatý, 2003).

\section{Suíca}

Conforme informação do Office of Civilian Radioactive Waste Management (2009) o combustível nuclear queimado, proveniente dos quatro reatores existentes na Suíça, é armazenado, por um período que varia de 1 a 10 anos, nas piscinas dos reatores 
suíços. Após o período de resfriamento, parte do CNQ segue para reprocessamento no Reino Unido ou França e a outra parte segue para armazenagem seca em ZWILAG (Figura 48), instalação temporária centralizada de curto prazo, construída para armazenar combustível nuclear queimado, rejeitos radioativos de atividade alta, rejeitos de atividade baixa acondicionados e rejeitos de atividade média e baixa tratados. O CNQ é enviado para ZWILAG em cascos de aço multi-propósito (Verdier et al., 2003) que são armazenados dentro da instalação, como mostra a Figura 49.

Local de armazenagem de CNQ

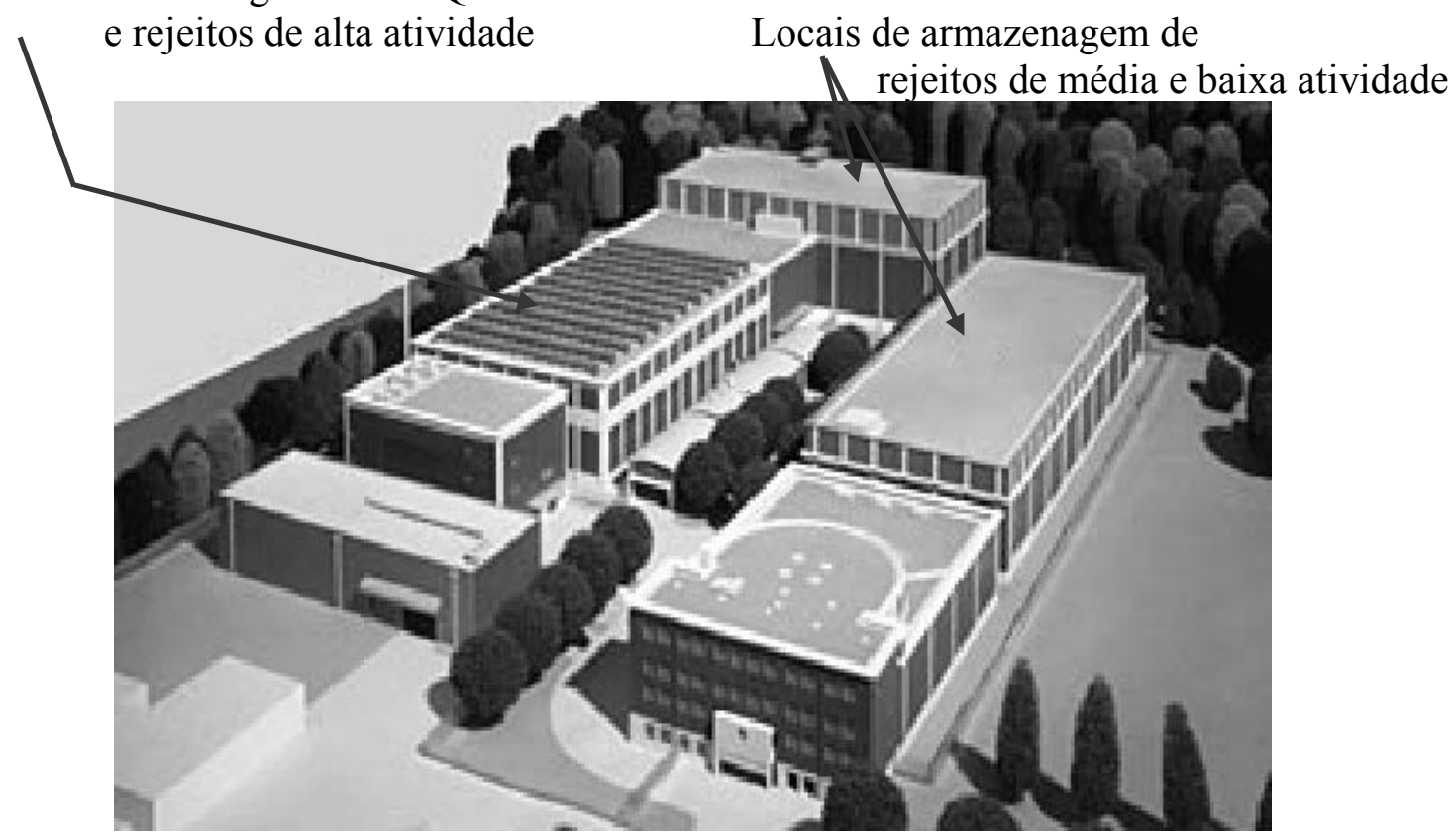

Figura 48 - Instalação de ZWILAG, Suíça, para armazenagem seca de CNQ. Fonte: Zwilag (2004)

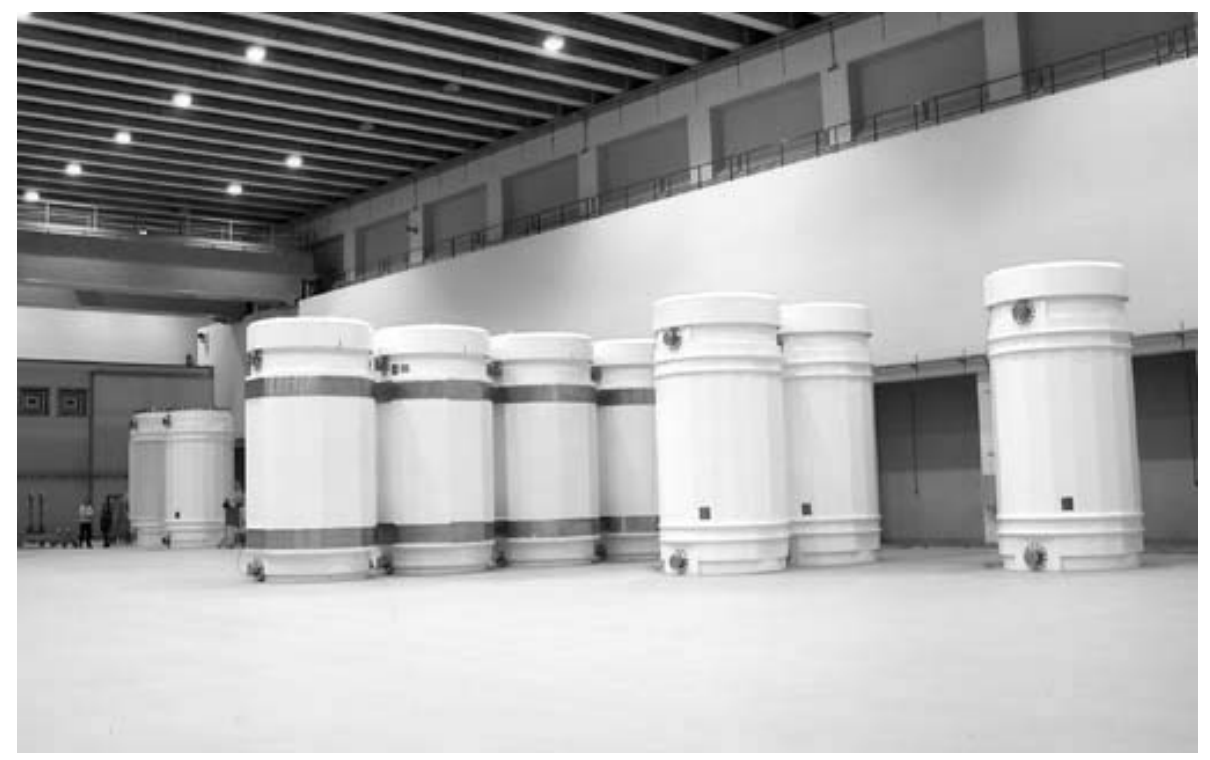

Figura 49 - Cascos de aço com CNQ armazenados dentro da instalação ZWILAG, Suíça. Fonte: Zwilag (2004) 


\section{Ucrânia}

A usina nuclear de Zaporizhzhya possui seis reatores nucleares VVER-1000 (PWR) e gera anualmente 300 elementos CNQ, conforme Marcelli e Smith (2002). A instalação de armazenagem provisória tem capacidade para armazenar 380 cascos de concreto ventilados. Cada casco é composto por um cilindro de aço carbono soldado que serve como blindagem, estrutura e possui tubos hexagonais de aço para receber 24 elementos CNQ. O conjunto é inserido em um cilindro de concreto reforçado construído de forma que ar possa circular internamente, propiciando resfriamento e ventilação. Os elementos CNQ são transferidos da piscina do reator para o casco mediante cascos de transferência. O casco ventilado é transportado para a instalação de armazenagem por meio de veículos especiais (Figura 50). A instalação de armazenagem é aberta e os cascos colocados sobre piso de concreto reforçado como se observa ao fundo da Figura 50 (Nuclear Energy Institute, 1997).

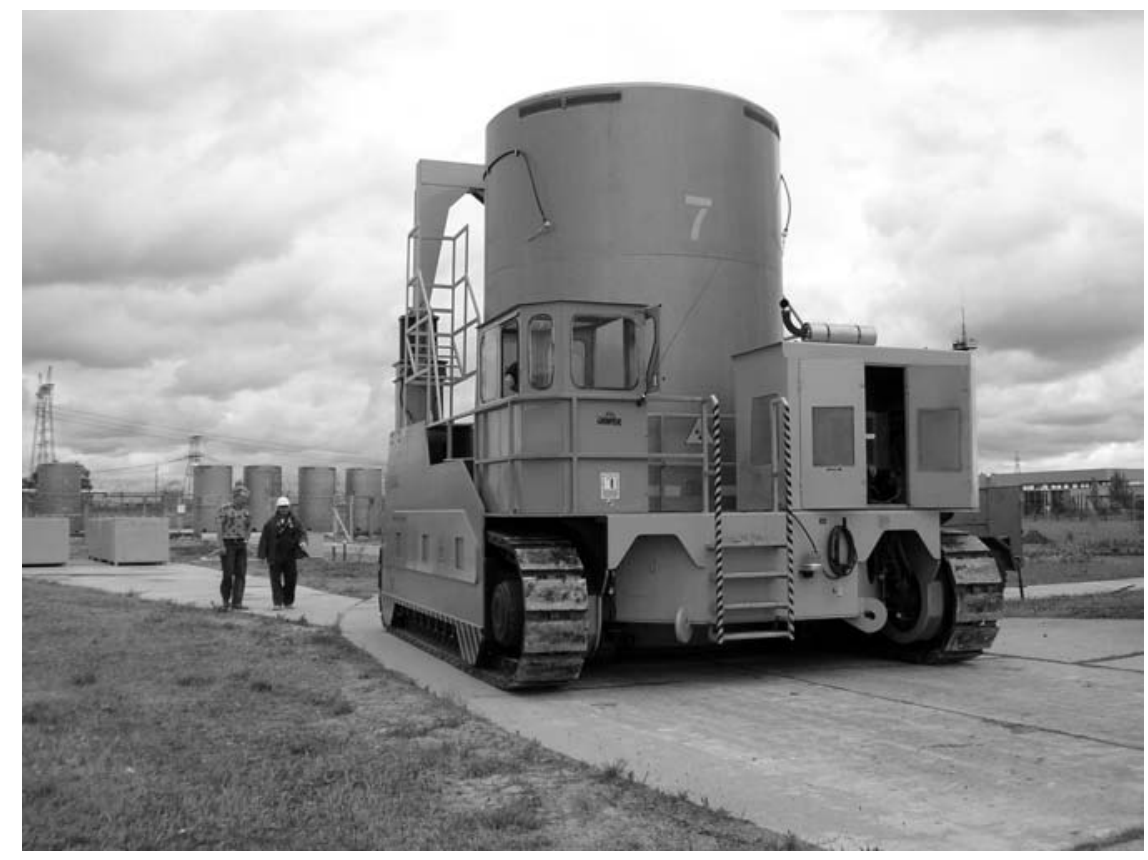

Figura 50 - Transporte do casco de concreto com CNQ, Zaporizhzhya, Ucrânia. Fonte: Zaporizhzhya NPP (2008)

Na Figura 51 é apresentado o esquema de armazenagem da instalação de Zaporizhzhya. 


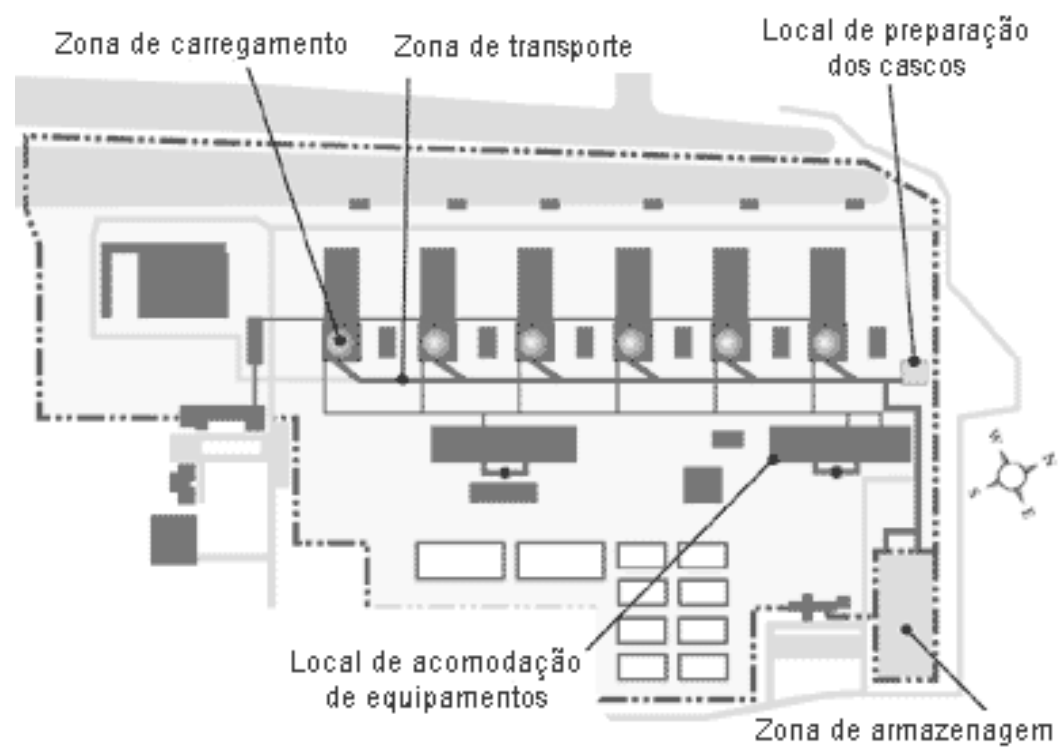

Figura 51 - Localização da zona de armazenagem seca de CNQ em Zaporizhzhya.

Fonte: Adaptado de Zaporizhzhya NPP (2008)

\subsubsection{Segurança de uma instalação de armazenagem de CNQ}

A segurança da instalação de armazenagem de CNQ é uma das prioridades de projeto, pois envolve não só o material armazenado, mas as pessoas diretamente envolvidas com a instalação (trabalhadores) e a população que vive ao seu redor. Naturalmente aquelas instalações que ficam próximas de cidades são consideradas mais vulneráveis do que as localizadas em regiões mais isoladas e que são acessadas poucas vezes ao ano.

No projeto de uma instalação de armazenagem seca, devem ser analisados vários fatores de segurança física como (Romanato e Rzyski, 2007): sismicidade do terreno, eventos atmosféricos intensos, intrusão humana com intenção agressiva, ou queda de aviões (IAEA, 1983).

A sismicidade faz parte dos chamados eventos externos à instalação de armazenagem, causados por fenômenos naturais. Sua análise é uma das prerrogativas na fase de escolha dos locais onde será construída a instalação.

Os eventos meteorológicos são fenômenos atmosféricos como ventos, chuvas, vendavais, tornados, enchentes, temperaturas fora das médias anuais previstas, que desempenham um papel importante no ponto de vista da segurança da instalação. Cada um dos eventos, apesar de ser estudado antes da construção da instalação, pode ser modificado ao longo dos anos e causar efeitos imprevistos no local de armazenagem. 
As chuvas podem afetar os cascos ou a proteção física da instalação de armazenagem (estruturas metálicas e edificações em concreto), caso sejam do tipo ácido. A chuva ácida pode ocorrer nas áreas sob influência de poluição urbana, pois ao cair nas superfícies citadas, altera a composição química das mesmas. De qualquer modo, cascos metálicos ou de concreto podem ter suas superfícies afetadas ao longo dos anos.

Os vendavais, dependendo da velocidade dos ventos $(80-102 \mathrm{~km} / \mathrm{h})$, não tendem a afetar os cascos de metal ou concreto ou as instalações dentro das quais são armazenados os cascos. A escala anemométrica de Beaufort classifica esses ventos como escala 10. Caso excedam $103 \mathrm{~km} / \mathrm{h}$, ou escala Beaufort 11, cuja classificação é tempestade violenta, objetos que tenham sido arrancados de outros edifícios podem ser lançados sobre a instalação e causar pequenos danos. (CEPAGRI, 2009)

As eventuais enchentes em sítios onde são armazenados cascos com CNQ, por no mínimo 20 anos, devem ser cuidadosamente avaliadas. Caso elas ocorram em instalações de armazenagem construídas em terrenos das centrais nucleares, que se localizam normalmente próximo a rios ou mares (caso de Angra), o perigo é ainda maior porque dentro desta categoria podem acontecer maremotos resultantes de sismos no terreno submarino próximo.

A erosão é o fenômeno do desgaste de sólidos provocado por ação das forças da natureza como vento (eólica), água (fluvial e marinha) ou gelo (glacial) (UNB, 2009).

No caso de sismicidade do terreno, apesar da baixa probabilidade de ocorrência de terremotos no Brasil, estes devem ser considerados, pois os sismos, dependendo de sua intensidade, podem produzir conseqüências severas. Conforme o Observatório Sismológico do Instituto de Geociências da Universidade de Brasília, os sismos no Brasil dificilmente chegam a magnitudes altas da escala Richter cujo limite máximo é 9 (embora, já tenham ocorrido no Brasil sismos de magnitude próxima a 5,5). (Observatório Sismológico, 2009) Sismos a partir da magnitude 6 da escala Richter podem causar danos no piso e ao prédio da instalação.

Outra categoria de eventos é conhecida como 'eventos externos induzidos pelo ser humano', nela podem ser citados: quedas de aviões, explosões químicas e outros atos provocados pelo homem. Os cascos de duplo propósito, durante o transporte e instalação, devem resistir a acidentes de trânsito, possibilidade de roubo do material radioativo durante o transporte, sabotagens, terrorismo e outros atos beligerantes (Hirsch e Neumann, 2001; Gregoric, 2006)). 
O ataque terrorista aos Estados Unidos, em 11 de setembro de 2001, resultou em ampliação da proteção física em diferentes tipos de instalações nucleares. Apesar do Brasil não ter apresentado problemas quanto a atos terroristas, esses devem ser levados em conta no projeto da instalação de armazenagem de CNQ.

A sabotagem geralmente é realizada por indivíduos que podem invadir as instalações e provocar danos de grande magnitude. Nesse caso, a armazenagem seca é menos vulnerável que a úmida em caso de sabotagens, como recomendam Marsh e Stanford (2001), e citam: “... a maior quantidade possivel de CNQ deve ser movida para uma instalação de armazenagem em cascos, que é menos vulnerável.".

Estudos realizados por Pennington e McGough (2002) mostram que um avião de passageiros do tipo Boeing 747 a $800 \mathrm{~km} / \mathrm{h}$, que colida contra um casco de concreto, não danificará sua estrutura. Um avião Boeing 737-300 tem capacidade para carregar 24.000L de combustível, o Boeing 747-400, 217.000L e um Boeing 767, 91.000L.

O combustível típico de jatos comerciais possui calor de combustão de $38 \mathrm{MJ} / \mathrm{L}$, ao passo que um quilograma de TNT possui $4,2 \mathrm{MJ}$ de energia. Portanto, um litro de combustível possui energia equivalente a $9 \mathrm{~kg}$ de TNT, mas a sobrepressão gerada pelo explosivo é muito maior que a do combustível. A explosão do combustível por causa do impacto de um avião contra uma instalação é muito menor que o do explosivo, pois a velocidade de queima do mesmo é muito maior, mas, mesmo assim, poderia gerar grande destruição (Thompson, 2003).

No caso de ser necessário construir uma instalação de armazenagem de CNQ robusta, ela deve também ser resistente a ataques terroristas ou sabotagens. Para evitar danos maiores como conseqüência dessas ações, deve ser considerada uma nova estratégia para a construção de instalações de armazenagem para CNQ (Thompson, 2003; Romanato e Rzyski, 2007).

Uma proposta de instalação robusta de armazenagem foi apresentada por Thompson (2003), na qual os cascos são colocados em abrigos individuais espaçados regularmente a cada $25 \mathrm{~m}$. Cada abrigo consistiria de um piso de concreto levemente acima do nível do solo, no qual o casco estaria apoiado e ao redor do casco haveria um tubo concêntrico e uma cobertura, ambos construídos em aço e concreto. Esse tubo seria coberto por terra e pedras, de forma que no final o formato fosse cônico (Figura 52). Para permitir o resfriamento do casco, existiriam canais para entrada e saída de ar. 


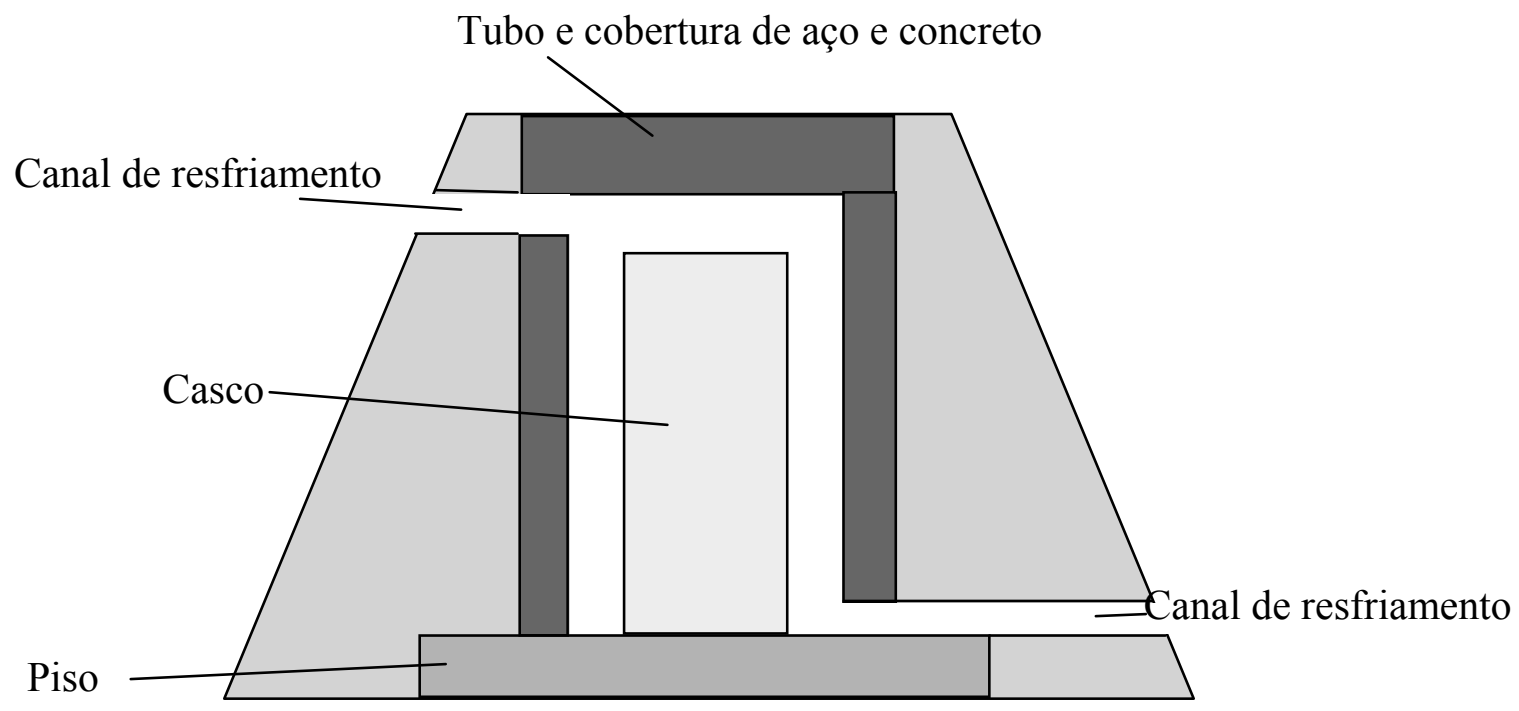

Figura 52 - Esquema de abrigo para cascos de CNQ para melhor proteção física.

Fonte: Adaptado de Thompson (2003)

\subsubsection{Vantagens da armazenagem seca em relação à úmida}

As instalações úmidas têm um alto grau de aceitação, pois os métodos estão normalizados e bem caracterizados. Durante os últimos 20 anos o controle do nível de corrosão dos elementos combustíveis armazenados em piscina foi melhorado mediante a utilização de materiais mais resistentes. O CNQ fica submerso em água à temperatura de aproximadamente $40^{\circ} \mathrm{C}$ e, nessa condição, a oxidação é favorecida, razão pela qual o processo de monitoração da corrosão tem que ser controlado. As desvantagens do sistema de armazenagem úmida são redundância dos sistemas elétricos e de resfriamento, e necessidade de manutenção do nível de água dentro de limites especificados (Romanato e Rzyski, 2006).

Os sistemas de armazenagem seca do CNQ garantem a blindagem contra a radiação emitida pelos radionuclídeos e o resfriamento é passivo.

Na Tabela 8 são mostradas as vantagens e desvantagens da armazenagem de CNQ em cascos para diferentes tipos de armazenagem, seca e úmida. 
Tabela 8. Vantagens e desvantagens nas armazenagens de CNQ.

\begin{tabular}{|c|c|c|}
\hline Tipo & Vantagens & Desvantagens \\
\hline \multicolumn{3}{|c|}{ Armazenagem úmida } \\
\hline Piscinas & $\begin{array}{l}\text { 1. Inspeção do CNQ } \\
\text { 2. Mobilidade do CNQ }\end{array}$ & $\begin{array}{l}\text { 1. Necessidade de controle da qualidade, } \\
\text { resfriamento e nível da água } \\
\text { 2. Corrosão dos metais } \\
\text { 3. Espaço de armazenagem restrito }\end{array}$ \\
\hline \multicolumn{3}{|c|}{ Armazenagem seca } \\
\hline Poços & $\begin{array}{l}\text { 1. Ausência de corrosão } \\
\text { 2. Resfriamento passivo }\end{array}$ & $\begin{array}{l}\text { 1. Dificuldade de inspeção do CNQ } \\
\text { 2. Não existe mobilidade dos cascos } \\
\text { 3. Espaço de armazenagem restrito }\end{array}$ \\
\hline Silos & $\begin{array}{l}\text { 1. Sem corrosão } \\
\text { 2. Resfriamento passivo } \\
\text { 3. Espaço de armazenagem variável }\end{array}$ & $\begin{array}{l}\text { 1. Inspeção do CNQ } \\
\text { 2. Não existe mobilidade dos cascos } \\
\text { 3. Não aproveitamento dos cascos de } \\
\text { transporte }\end{array}$ \\
\hline Cascos metálicos & $\begin{array}{l}\text { 1. Sem corrosão } \\
\text { 2. Resfriamento passivo } \\
\text { 3. Casco de armazenagem pode ser o } \\
\text { mesmo que para o transporte } \\
\text { 4. Mobilidade dos cascos } \\
\text { 5. Espaço de armazenagem variável ou } \\
\text { sistema modular }\end{array}$ & 1. Inspeção do CNQ \\
\hline Cascos de concreto & $\begin{array}{l}\text { 1. Sem corrosão } \\
\text { 2. Resfriamento passivo } \\
\text { 3. Casco de armazenagem pode ser o } \\
\text { mesmo que para o transporte } \\
\text { 4. Mobilidade dos cascos } \\
\text { 5. Espaço de armazenagem variável } \\
\text { 6. Custos menores que os metálicos }\end{array}$ & $\begin{array}{l}\text { 1. Inspeção do CNQ } \\
\text { 2. Massa do casco maior que a massa } \\
\text { metálica }\end{array}$ \\
\hline
\end{tabular}

Uma desvantagem em todos os sistemas de armazenagem seca é a impossibilidade de se inspecionar os elementos CNQ sem a abertura do casco. Como a abertura não é indicada a não ser em instalações especialmente construídas para tal propósito, a inspeção rotineira fica prejudicada. Pode-se, no entanto fazer uma monitoração contínua do controle da estanqueidade do casco, como ocorre na Espanha.

Conforme o National Research Council (2006), outras vantagens potenciais são a existência de uma menor quantidade de CNQ em risco de acidente ou de ataque em uma instalação de armazenagem seca do que em uma piscina. Um acidente ou ataque afetaria poucos cascos e apenas algumas toneladas de CNQ estariam em risco. No caso de um ataque a uma piscina, todo o inventário de CNQ armazenado estaria, potencialmente, em risco, isto é, centenas de toneladas de CNQ.

As conseqüências de um acidente ou ataque terrorista em uma instalação de armazenagem seca são menores que aqueles contra uma piscina, pelas razões seguintes: 
a. Existe uma quantidade menor de CNQ em um casco de armazenagem que em uma piscina e, portanto menos material radioativo que possa ser, eventualmente, liberado para o meio ambiente.

b. A liberação de material radioativo ocorreria por dispersão mecânica. Essa liberação seria relativamente pequena.

c. Em caso de incêndio, a liberação do material radioativo também pode ocorrer como resultado da queima do revestimento de zircônio, que produziria aerossóis radioativos. Um incêndio tem o potencial de liberar grandes quantidades de material radioativo no ambiente.

d. A recuperação após um ataque contra um casco seria mais simples que a recuperação do local de armazenagem em uma piscina.

A armazenagem seca em cascos é consideravelmente simples e extremamente segura e confiável. É uma prática utilizada em várias instalações nucleares no mundo e nos EUA desde meados de 1980 (Indian Point, 2008). Aproximadamente metade das usinas nucleares nos EUA utiliza a armazenagem seca ou têm projetos para implantá-la.

\subsubsection{Comparação dos custos de instalação de armazenagem de CNQ}

A comparação entre os custos de uma instalação de armazenagem pode ser vista na Tabela 9 (Earle, 2002). Essa estimativa foi baseada em um combustível genérico e as comparações entre as armazenagens são relativas ao casco de duplo propósito.

Tabela 9 - Custos relativos de uma instalação de armazenagem seca

\begin{tabular}{lc}
\hline Tipo de armazenagem & Custos relativos \\
\hline Casco - duplo propósito & 1 \\
Casco de armazenagem simples & $0,61-0,86$ \\
Poços de convecção & $0,62-0,75$ \\
Silos & $0,5-0,6$ \\
Túmulos (cilindros enterrados) & 0,29 \\
\hline
\end{tabular}

Fonte: Adaptado de Earle (2002)

\subsection{Regulamentação para o desenvolvimento de cascos para CNQ}

A regulamentação por órgãos competentes é parte fundamental no desenvolvimento de um casco para armazenagem de CNQ. 
A IAEA é o órgão que estabelece a regulamentação nuclear no mundo. Nos Estados Unidos existe a USNRC e em vários países existem organismos regulamentadores específicos. No Brasil, o órgão regulamentador é a CNEN.

Os aspectos que regulamentam o processo de concepção do casco estão representados conceitualmente na Figura 53 (IAEA, 2006). As diversas áreas técnicas de projeto são representadas como setores no conjunto dos círculos (Blindagem, Contenção/estrutura, Criticalidade, Térmica). Os três círculos concêntricos mostram os níveis de regulação (externo, intermediário, central).

O círculo externo representa o limite físico.

Quanto à criticalidade, o círculo externo mostra o limite físico igual a 1,0, que é o limiar de um evento de criticalidade. O próximo círculo mais interno é o limite regulamentar formal. Neste caso, esse limite tem o valor de 0,95 , referenciado na maior parte dos regulamentos nacionais. É importante notar que, seria altamente improvável que o conteúdo de um casco carregado com um nível crítico de 0,95 atingisse a criticalidade do limite físico, com valor 1,0 . O limite regulamentar de 0,95 proporciona um nível elevado de segurança e conservadorismo. Em razão desta filosofia, o nível de segurança é usado para o estabelecimento dos limites regulamentares nas outras áreas de concepção. A mesma observação quanto à incorporação de níveis de segurança maiores e conservativos pode ser efetuada para os limites regulamentares em outras áreas do projeto.

O círculo mais interno da Figura 53 mostra o nível de segurança resultante das práticas atuais. Quanto à criticalidade, este limite pode ser de aproximadamente 0,93, menor que o limite regulamentar de 0,95. É mais conservador que a criticalidade regulamentar e é utilizado por causa das incertezas na análise da criticalidade obtida nos resultados do programa, combinada com as incertezas dos dados experimentais utilizados para validar a capacidade de análise do programa.

O círculo interno também pode ser definido como a capacidade do desempenho global do projeto do casco: à medida que o círculo é ampliado, a capacidade do desempenho do casco pode ser aumentada.

Inserindo novas percepções de segurança em algumas áreas, tais como o risco de terrorismo, poder-se-ia também reduzir o tamanho do círculo. 


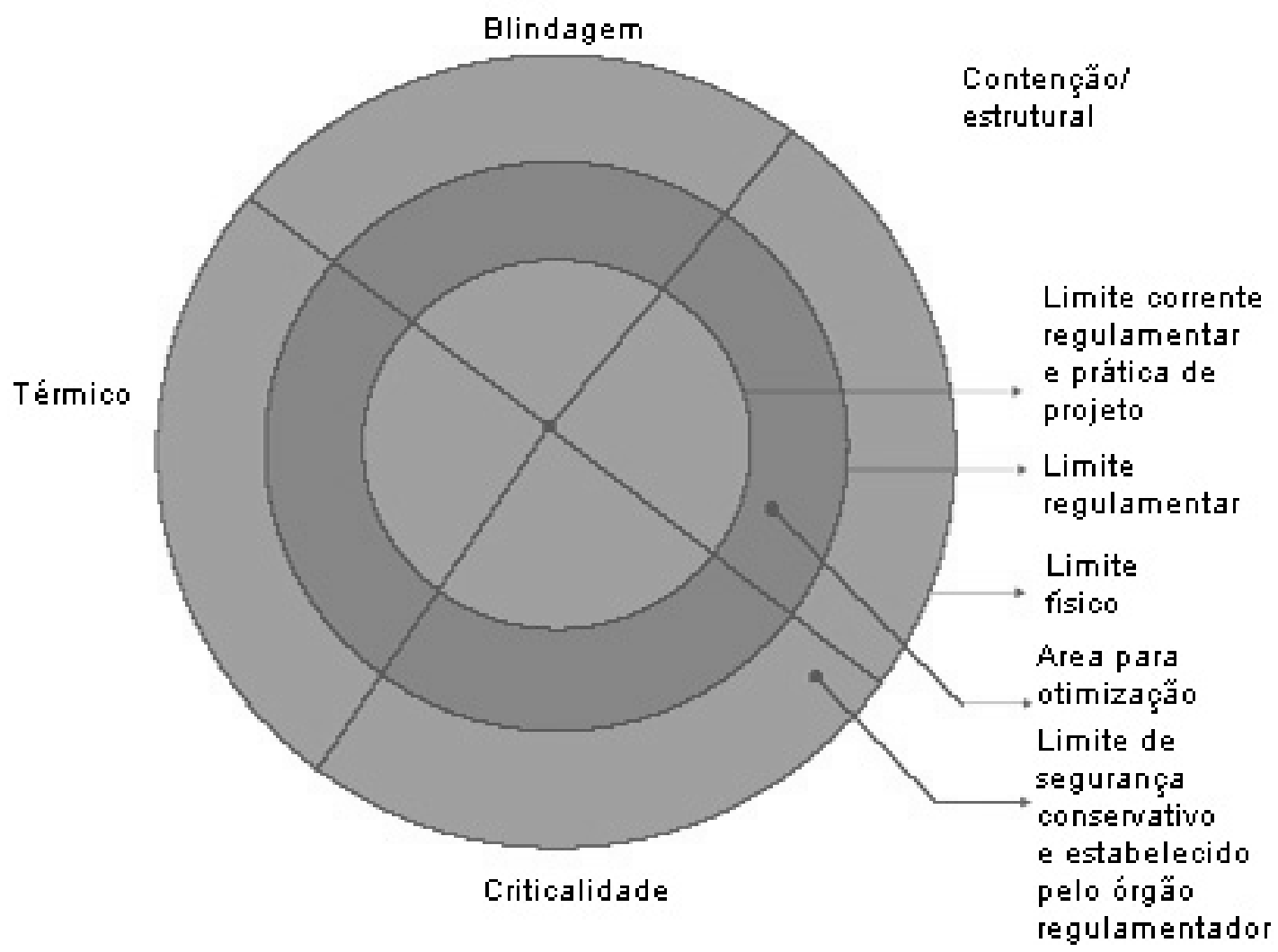

Figura 53 - Conceito dos limites regulamentares na concepção de um casco de armazenagem de CNQ

Fonte: Adaptado de IAEA, 2006

Finalmente, o anel de cor escura entre os círculos pode ser entendido como a área objeto de grande parte dos esforços de otimização do projeto. Neste conceito, a meta é reduzir o tamanho deste anel e aumentar o tamanho do círculo interno, para reduzir o excesso de conservadorismo, pressuposto na análise de segurança, e reduzir as incertezas nos resultados de análises de segurança. Aumenta-se, assim, a precisão dos modelos físicos incorporados nas ferramentas de análise e os dados utilizados na validação de modelos ou de modelos e ferramentas.

\subsection{Transporte de cascos com CNQ}

O transporte de cascos com CNQ, do reator para locais de armazenagem temporária ou para instalações de reprocessamento, é vital no ciclo do combustível. Um grande número de operações de transporte foi realizado em vários países, sem registro de incidentes importantes. A estimativa é que tenham sido transportadas, até 2006, 100.000tHM de CNQ por via rodoviária, férrea, fluvial e marítima (IAEA, 2007). 
Um exemplo genérico de casco para transporte ferroviário de CNQ-PWR é mostrado na Figura 54.

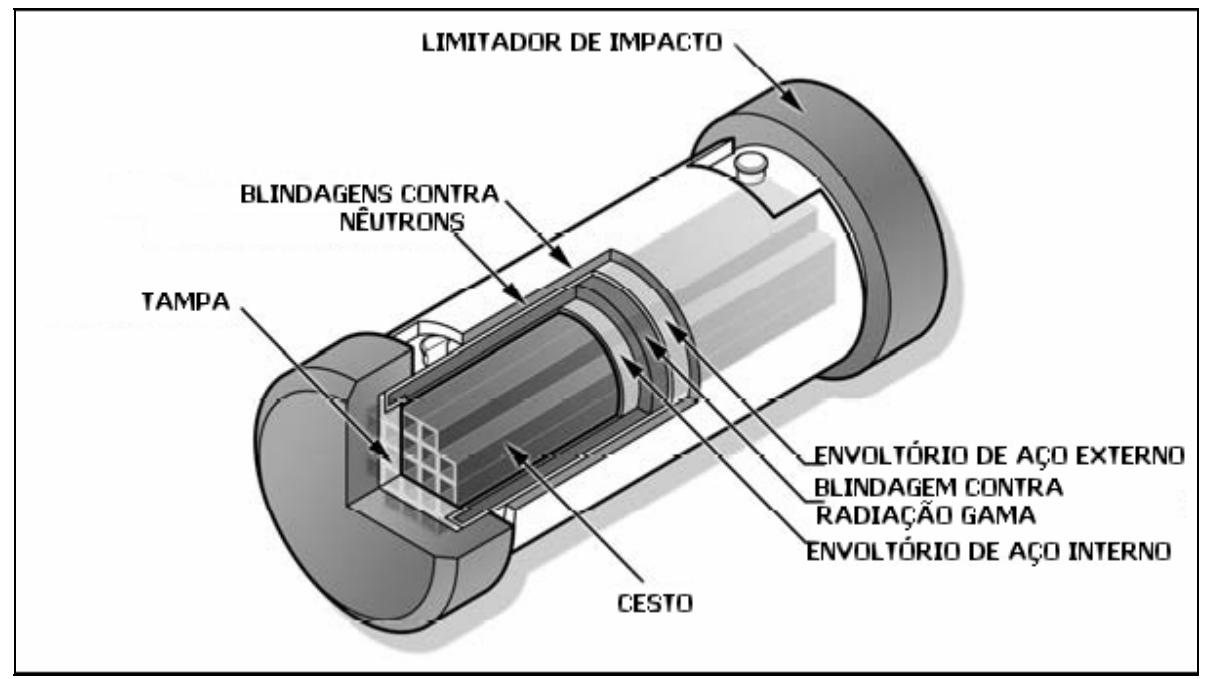

Figura 54 - Exemplo de casco de transporte ferroviário de CNQ-PWR

Fonte: Adaptado de USNRC, 2007a

O transporte do CNQ do reator até o local de armazenagem provisória é um processo que envolve várias fases e é necessário muito cuidado para que não haja liberação de material radioativo para o meio ambiente. Esse processo pode ser dividido nas fases seguintes (Romanato e Rzyski, 2003):

- Retirada do combustível da piscina do reator;

- Colocação do combustível no casco de transporte;

- Fechamento do casco;

- Secagem do elemento combustível;

- Transferência do casco até o meio de transporte;

- Transporte, propriamente dito;

- Desembarque do casco no local de destino; e,

- Transferência para o casco de armazenagem.

No caso de utilização de um casco de duplo propósito, não se usa o casco de transferência.

Na Figura 55, é apresentado um diagrama com as diversas fases do processo de transporte. 


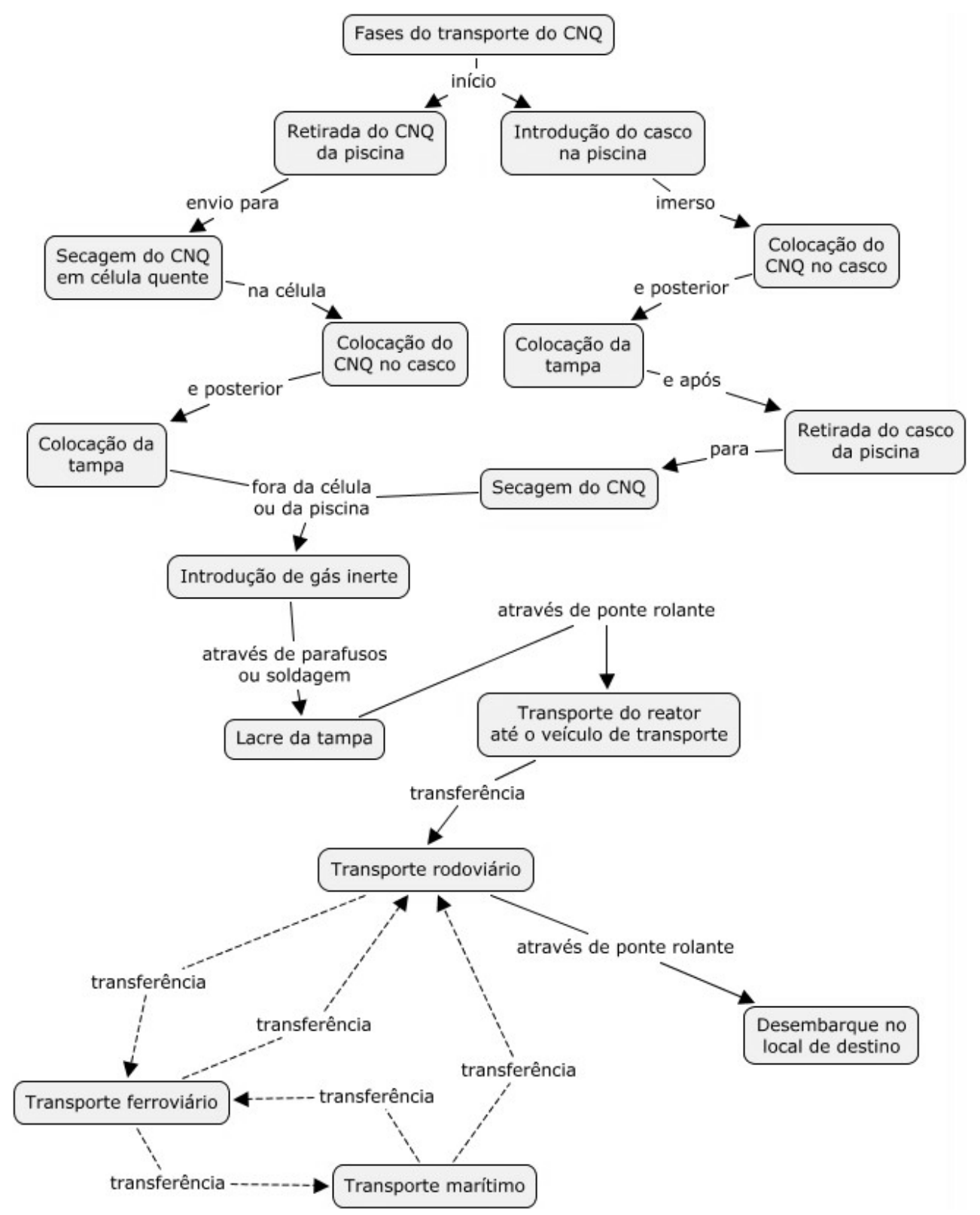

Figura 55 - Fluxograma do transporte de cascos com CNQ

Fonte: Adaptado de Romanato e Rzyski (2003)

Caso a instalação de armazenagem esteja localizada longe do reator, o transporte do CNQ acondicionado em cascos pode ser feito por via rodoviária, ferroviária ou marítima. Todos os veículos de transporte são especiais como mostram as Figuras 56, 57 e 58 para as três modalidades (rodoviária, ferroviária e marítima). 


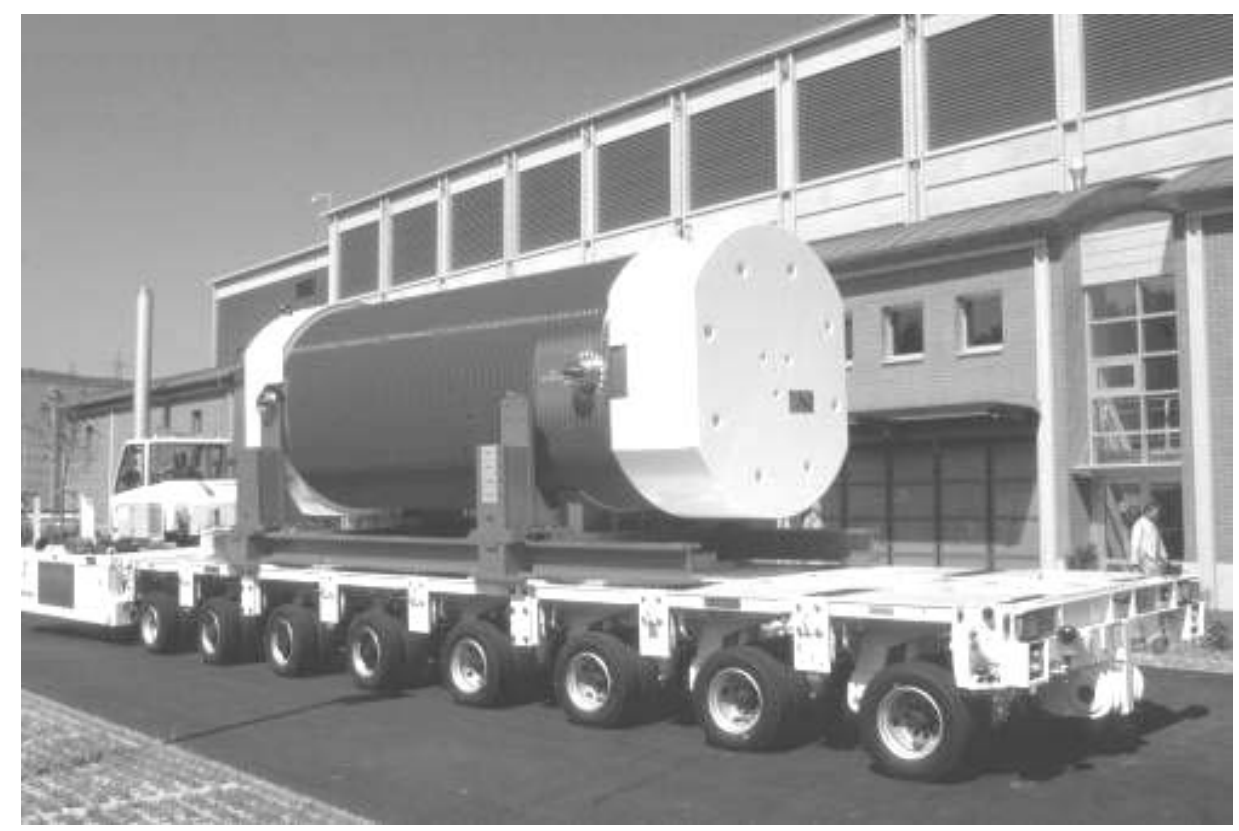

Figura 56 - Transporte rodoviário de casco metálico de CNQ

Fonte: Zwilag (2004)

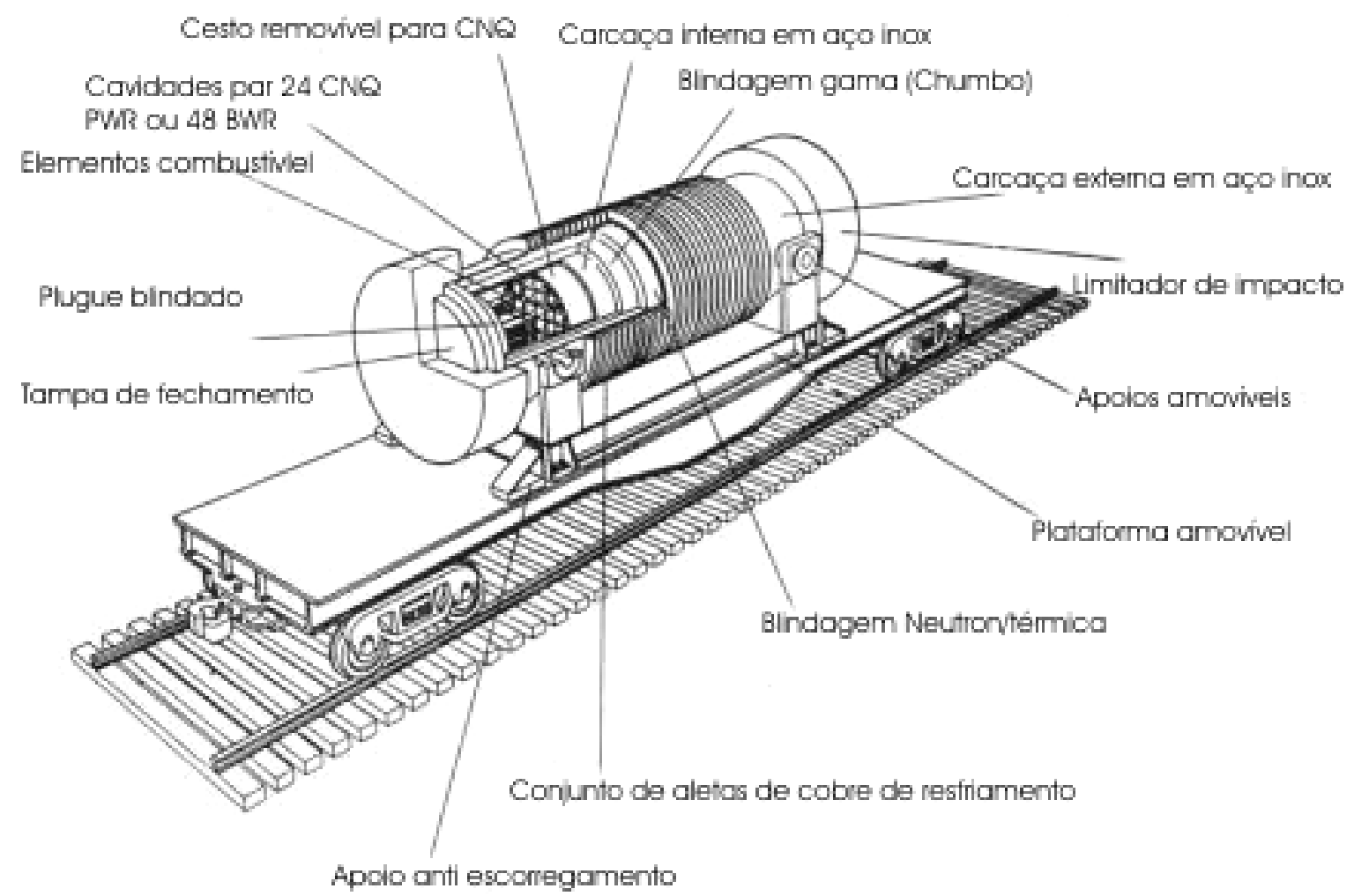

Figura 57 - Corte de um casco utilizado em transporte ferroviário Fonte: Adaptado de Cochran e Tsoulfanidis (1992) 


\section{Navio cargueiro de transporte de combustivel nuclear}

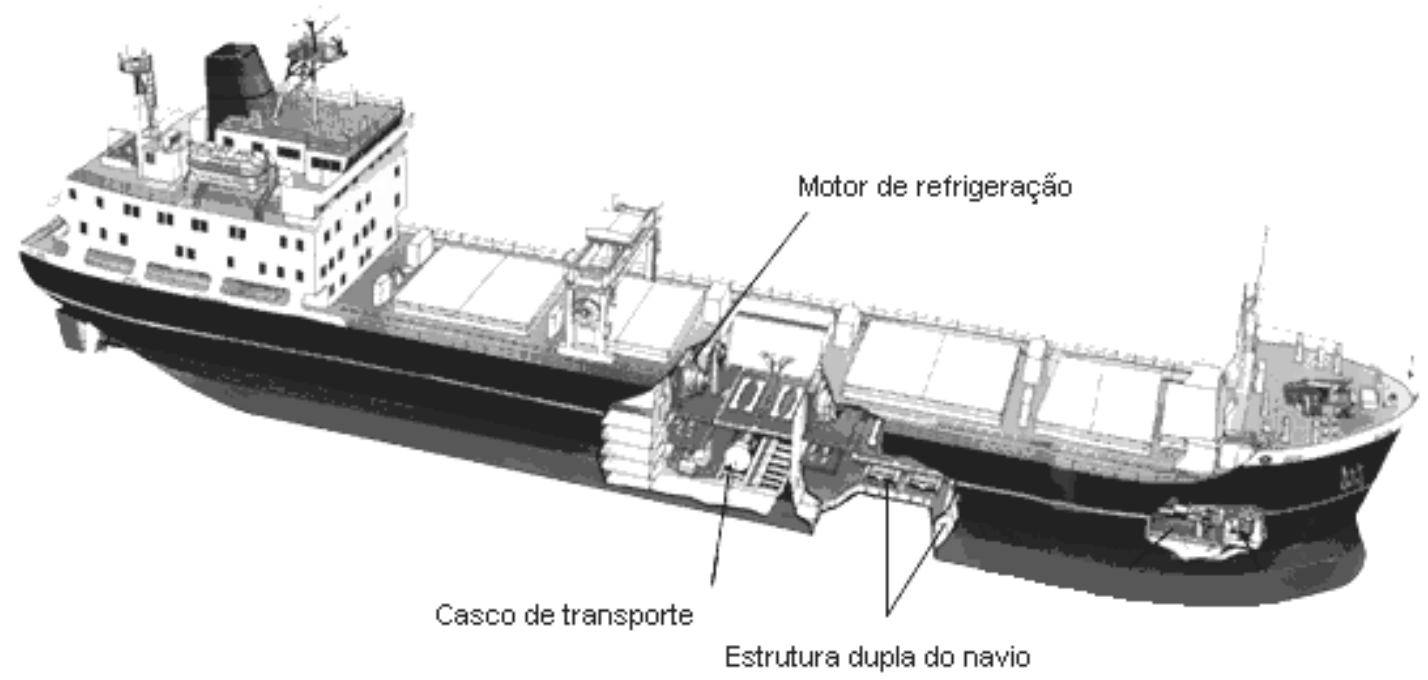

Figura 58 - Corte de um navio usado no transporte marítimo de CNQ.

Fonte: Adaptado de WNA (2009)

O transporte do CNQ desde o reator até a instalação é um ponto importante e sensível, e potencialmente sujeito a acidentes.

A forma de transporte mais simples é realizada colocando-se o casco diretamente, na horizontal ou na vertical, em um veículo reboque especial rodoviário e transportando-o até o seu destino. Porém, o transporte pode ser multimodal e envolver vários veículos, atingindo uma maior complexidade como a colocação do casco com CNQ em um veículo de transferência, seu transporte até o veículo reboque especial rodoviário e transferência do casco para este, o transporte via rodoviária até uma estação ferroviária; a realização de uma nova transferência do casco para um vagão ferroviário por meio de guindastes ou pontes rolantes, o transporte via férrea até uma estação portuária; o embarque do casco, por meio de guindastes, para um local específico de um navio adaptado; o transporte via marítima ao porto de destino; a realização das operações de desembarque do navio, colocando o casco em um vagão especial, ou num veículo rodoviário, e transporte até a instalação, por via férrea ou rodoviária (Romanato e Rzyski, 2005).

Esses fluxos podem ser ainda mais complexos dependendo da malha de transporte do país. Toda operação de embarque e desembarque requer equipamentos e pessoal especializado, visto o perigo de liberação de radioatividade e do elevado peso do 
casco. A amarração dos cascos nos veículos rodoviários e plataformas ferroviárias deve ser muito confiável, utilizando-se métodos experimentados de amarração.

No transporte rodoviário e ferroviário, além do estado do veículo transportador, deve ser levada em conta a condição da malha viária, condições climáticas e tudo mais que possa causar acidentes. A execução de verificações no veículo transportador é de grande valia, pois, além da vistoria, propicia a realização de manutenções preventivas e corretivas. O motorista deve ser habilitado, com experiência suficiente no transporte de cargas pesadas e perigosas. (Romanato e Rzyski, 2005)

No transporte marítimo, a probabilidade de ocorrência de colisões é menor, apesar de acontecerem em virtude do tráfego existente próximo aos portos, e deve-se também levar em consideração, as condições climáticas que possam ocasionar naufrágios. Nunca houve acidentes graves com ruptura ou vazamento dos cascos contendo CNQ (WNA, 2009). Os navios de transporte são projetados de modo a resistir a colisões laterais com navios petroleiros. Em caso de naufrágio, o casco ainda permaneceria por muito tempo preservado, de modo que sua recuperação seja possível, já que na instrumentação são incluídas bóias de localização monitoradas. Outro aspecto importante no transporte é a possibilidade de sabotagens, roubos e atos terroristas, que apesar de difícil ocorrência, nos dias de hoje, não devem ser desprezados. 
4 PROPOSTA DE CASCO E INSTALAÇÃO DE ARMAZENAGEM NACIONAIS PARA CNQ-PWR 


\section{PROPOSTA DE CASCO E INSTALAÇÃO DE ARMAZENAGEM NACIONAIS PARA CNQ-PWR}

Neste capítulo é apresentada uma proposta de casco e instalação de armazenagem seca para o CNQ gerado em reatores PWR no Brasil. Para esta finalidade foi escolhido o perfil da instalação da Central Nuclear Almirante Álvaro Alberto (CNAAA), em Angra dos Reis, Rio de Janeiro, que atualmente é formada pelo complexo das Usinas Angra 1 e Angra 2 e futuramente terá a Usina Angra 3 em funcionamento.

\subsection{Proposta de casco nacional de armazenagem de CNQ}

$\mathrm{Na}$ escolha dos materiais que serão utilizados na confecção de um casco de armazenagem nacional para CNQ de PWR, deve ser observada a capacidade de contenção e de blindagem. A manutenção da distribuição geométrica original dos elementos de CNQ e, consequentemente, subcriticalidade, devem ser mantidas nas condições normais de operação e nas condições de acidentes postuladas. Os materiais utilizados para confeccionar o casco devem permitir que o mesmo transfira o calor gerado durante o decaimento dos radioisótopos contidos no CNQ armazenado em condições normais, para o meio ambiente e prevenir o aquecimento acima do limite previsto que possa causar danos ao casco.

No projeto final do casco devem ser levadas em consideração as propriedades mecânicas dos materiais, tais como rigidez, ductilidade, elasticidade, resistência à fadiga, resistência à corrosão, dureza, tenacidade e fluência. O ANEXO B relaciona as normas utilizadas na Alemanha para o projeto e construção de um casco metálico, bem como de materiais, solda, controle e testes, conforme Cumo et al. (2004).

Para que a dose de radiação na superfície esteja abaixo dos limites máximos estabelecidos na norma CNEN NN-5.01 (CNEN, 1988) e complementada pelas normas 10 CFR 71 (USNRC, 2009) e 10 CFR 72 (USNRC, 2009a), os materiais que compõem o casco devem blindar com eficiência a radiação gama e os nêutrons. O princípio ALARA deve ser adotado, permitindo que se atinja segurança máxima com os recursos, sistemas e pessoal disponíveis.

Em estudos realizados por Shappert et al. (1998) em Oak Ridge National Laboratory (ORNL), os autores calcularam, para o CNQ considerado, as espessuras de paredes dos cascos confeccionadas com alguns materiais, cujos valores estão apresentados nas Tabelas 10 a 14. 
O CNQ considerado por Shappert et al. (1998), foi o de um reator PWR, com burnup de $33 \mathrm{GWd} / \mathrm{tU}$. Os cálculos foram feitos com auxílio do código CAPSIZE, desenvolvido pelo próprio ORNL, e foram levadas em conta as taxas de doses de radiação de $0,09 \mathrm{mSv} / \mathrm{h}$ para raios gama e $0,01 \mathrm{mSv} / \mathrm{h}$ para nêutrons, à uma distância cerca de $3 \mathrm{~m}$ do eixo central do casco (Shappert et al., 1998).

As Tabelas 10 a 14 foram elaboradas considerando o chumbo, ferro e urânio exaurido como blindagem contra raios gama e material hidrogenado para blindagem contra nêutrons, separados por camadas de aço, conforme mostra a Figura 59. Originalmente, na literatura de Shappert foi considerada, para blindagem contra nêutrons, uma mistura de água e etlieno glicol, mas para o casco proposto nesse trabalho, o material sugerido é o polietileno de alta densidade. Nessas tabelas, o casco de aço com blindagem de chumbo é denominado "Casco de $\mathrm{Pb}$ ", o de aço puro "Casco de Fe" e aquele com blindagem de urânio empobrecido "Casco de U”.

Tabela 10 - Espessura da blindagem para CNQ-PWR, burnup de $33 \mathrm{GWd} / \mathrm{tU}$, dois anos de resfriamento.

\begin{tabular}{c|cc|c|c|c|c}
\cline { 2 - 7 } Número de & \multicolumn{7}{c}{ Espessura $\left(10^{-2} \mathrm{~m}\right)$} \\
\cline { 2 - 7 } elementos & $\gamma^{1}$ & $\mathrm{n}^{2}$ & $\gamma$ & $\mathrm{n}$ & $\gamma$ & $\mathrm{n}$ \\
\hline 1 & 11,4 & 9,4 & 25,7 & 9,4 & 6,9 & 7,9 \\
4 & 12,5 & 10,1 & 27,5 & 9,8 & 7,6 & 8,4 \\
8 & 13,2 & 10,3 & 28,4 & 9,8 & 7,95 & 8,9 \\
10 & 13,4 & 10,5 & 28,8 & 9,9 & 8,0 & 9,1 \\
12 & 13,6 & 10,8 & 29,1 & 9,9 & 8,2 & 9,3 \\
15 & 13,8 & 10,8 & 29,4 & 9,9 & 8,3 & 9,3 \\
18 & 13,9 & 10,8 & 29,6 & 10,0 & 8,4 & 9,3 \\
21 & 14,2 & 11,1 & 29,9 & 10,0 & 8,5 & 9,5 \\
\hline
\end{tabular}

1 = radiação gama; 2 = emissão de nêutrons; $\mathrm{Pb}=$ chumbo; $\mathrm{Fe}=$ ferro; $\mathrm{U}=$ urânio.

Fonte: Adaptado de Shappert et al. (1998)

Tabela 11 - Espessura da blindagem para CNQ-PWR, burnup de $33 \mathrm{GWd} / \mathrm{tU}$, três anos de resfriamento.

\begin{tabular}{c|cc|c|c|c|c}
\cline { 2 - 7 } & \multicolumn{7}{c}{ Espessura $\left(10^{-2} \mathrm{~m}\right)$} \\
\hline \multirow{2}{*}{$\begin{array}{c}\text { Número de } \\
\text { elementos }\end{array}$} & \multicolumn{2}{c}{ Casco de $\mathrm{Pb}$} & \multicolumn{2}{c}{ Casco de Fe } & \multicolumn{2}{c}{ Casco de U } \\
\cline { 2 - 7 } & $\gamma^{1}$ & $\mathrm{n}^{2}$ & $\gamma$ & $\mathrm{n}$ & $\gamma$ & $\mathrm{n}$ \\
\hline 1 & 10,3 & 9,5 & 24,2 & 9,42 & 6,3 & 7,3 \\
4 & 11,4 & 10,1 & 25,9 & 9,6 & 7,0 & 8,1 \\
8 & 12,0 & 10,3 & 26,8 & 9,5 & 7,3 & 8,4 \\
12 & 12,5 & 10,6 & 27,5 & 9,6 & 7,6 & 8,8 \\
15 & 12,7 & 10,7 & 27,7 & 9,6 & 7,7 & 9,1 \\
18 & 12,8 & 10,8 & 27,9 & 9,7 & 7,8 & 9,1 \\
21 & 13,0 & 11,0 & 28,2 & 9,8 & 7,9 & 9,2 \\
\hline
\end{tabular}

1 = radiação gama; 2 = emissão de nêutrons; $\mathrm{Pb}=$ chumbo; $\mathrm{Fe}$ = ferro; $\mathrm{U}$ = urânio (DU).

Fonte: Adaptado de Shappert et al. (1998) 
Tabela 12 - Espessura da blindagem para CNQ-PWR, burnup de $33 \mathrm{GWd} / \mathrm{tU}$, cinco anos de resfriamento.

\begin{tabular}{c|ccc|c|c|c}
\cline { 2 - 7 } Número de & \multicolumn{2}{c}{ Casco de $\mathrm{Pb}$} & \multicolumn{2}{c}{ Casco de Fe } & \multicolumn{2}{c}{ Casco de U } \\
\cline { 2 - 7 } elementos & $\gamma^{1}$ & $\mathrm{n}^{2}$ & $\gamma$ & $\mathrm{n}$ & $\gamma$ & $\mathrm{n}$ \\
\hline 1 & 9,0 & 9,1 & 22,3 & 8,7 & 5,6 & 6,5 \\
4 & 10,1 & 9,8 & 23,9 & 8,8 & 6,2 & 7,2 \\
8 & 10,6 & 10,0 & 24,8 & 8,9 & 6,6 & 7,9 \\
12 & 11,1 & 10,3 & 25,6 & 9,1 & 6,8 & 8,4 \\
15 & 11,3 & 10,4 & 25,7 & 9,1 & 6,9 & 8,5 \\
18 & 11,4 & 10,4 & 25,9 & 9,1 & 7,0 & 8,5 \\
21 & 11,6 & 10,7 & 26,2 & 9,2 & 7,1 & 8,8 \\
24 & 11,7 & 10,8 & 26,3 & 9,3 & 7,1 & 8,8 \\
\hline
\end{tabular}

1 = radiação gama; 2 = emissão de nêutrons; $\mathrm{Pb}=$ chumbo; $\mathrm{Fe}=$ ferro; $\mathrm{U}$ = urânio (DU).

Fonte: Adaptado de Shappert et al. (1998)

Tabela 13 - Espessura da blindagem para CNQ-PWR, burnup de $33 \mathrm{GWd} / \mathrm{tU}$, sete anos de resfriamento.

\begin{tabular}{|c|c|c|c|c|c|c|}
\hline \multirow{3}{*}{$\begin{array}{l}\text { Número de } \\
\text { elementos }\end{array}$} & \multicolumn{6}{|c|}{ Espessura $\left(10^{-2} \mathrm{~m}\right)$} \\
\hline & \multicolumn{2}{|c|}{ Casco de $\mathrm{Pb}$} & \multicolumn{2}{|c|}{ Casco de Fe } & \multicolumn{2}{|c|}{ Casco de U } \\
\hline & $\gamma^{1}$ & $\mathrm{n}^{2}$ & $\gamma$ & $\mathrm{n}$ & $\gamma$ & $\mathrm{n}$ \\
\hline 1 & 8,3 & 9,06 & 21,2 & 8,9 & 5,2 & 6,8 \\
\hline 4 & 9,4 & 9,4 & 22,8 & 8,9 & 5,8 & 7,4 \\
\hline 8 & 9,9 & 9,7 & 23,7 & 9,0 & 6,1 & 8,0 \\
\hline 12 & 10,4 & 10,0 & 24,3 & 9,1 & 6,4 & 8,5 \\
\hline 15 & 10,5 & 10,0 & 24,5 & 9,1 & 6,4 & 8,6 \\
\hline 18 & 10,7 & 10,2 & 24,7 & 9,1 & 6,5 & 8,6 \\
\hline 21 & 10,9 & 10,2 & 25,0 & 9,2 & 6,6 & 8,9 \\
\hline 26 & 11,1 & 10,6 & 25,3 & 9,4 & 6,7 & 9,0 \\
\hline
\end{tabular}

Fonte: Adaptado de Shappert et al. (1998)

Tabela 14 - Espessura da blindagem para CNQ-PWR, burnup de $33 \mathrm{GWd} / \mathrm{tU}$, dez anos de resfriamento.

\begin{tabular}{c|ccc|c|c|c}
\cline { 2 - 7 } \multirow{2}{*}{$\begin{array}{c}\text { Número de } \\
\text { elementos }\end{array}$} & \multicolumn{2}{c}{ Casco de $\mathrm{Pb}$} & \multicolumn{2}{c}{ Casco de Fe } & \multicolumn{2}{c}{ Casco de U } \\
\cline { 2 - 7 } & $\gamma^{1}$ & $\mathrm{n}^{2}$ & $\gamma$ & $\mathrm{n}$ & $\gamma$ & $\mathrm{n}$ \\
\hline 1 & 7,6 & 9,4 & 20,1 & 9,2 & 4,8 & 6,7 \\
4 & 8,6 & 9,7 & 21,6 & 9,3 & 5,4 & 7,3 \\
8 & 9,2 & 10,0 & 22,5 & 9,3 & 5,7 & 7,8 \\
12 & 9,6 & 10,3 & 23,1 & 9,4 & 5,9 & 8,3 \\
18 & 9,9 & 10,3 & 23,6 & 9,4 & 6,1 & 8,6 \\
21 & 10,1 & 10,5 & 23,9 & 9,4 & 6,2 & 8,7 \\
26 & 10,3 & 10,8 & 24,1 & 9,5 & 6,3 & 8,8 \\
\hline
\end{tabular}

$1=$ radiação gama; 2 = emissão de nêutrons; $\mathrm{Pb}=$ chumbo; $\mathrm{Fe}=$ ferro; $\mathrm{U}$ = urânio (DU).

Fonte: Adaptado de Shappert et al. (1998) 
Após a análise das tabelas acima, concluiu-se que a alternativa otimizada é a de resfriamento do CNQ por cinco anos em piscina, antes da transferência para um casco de transporte e armazenagem. A partir desse tempo, os cálculos mostram que a diminuição na espessura da blindagem, necessária para atender os limites de doses estabelecidos, é muito pequena quando comparada com o tempo de resfriamento. Para tempos de esfriamento menores que cinco anos, as espessuras necessárias são de tal monta, que o volume do casco e conseqüentemente a massa, inviabilizariam sua construção por causa das dimensões e massa.

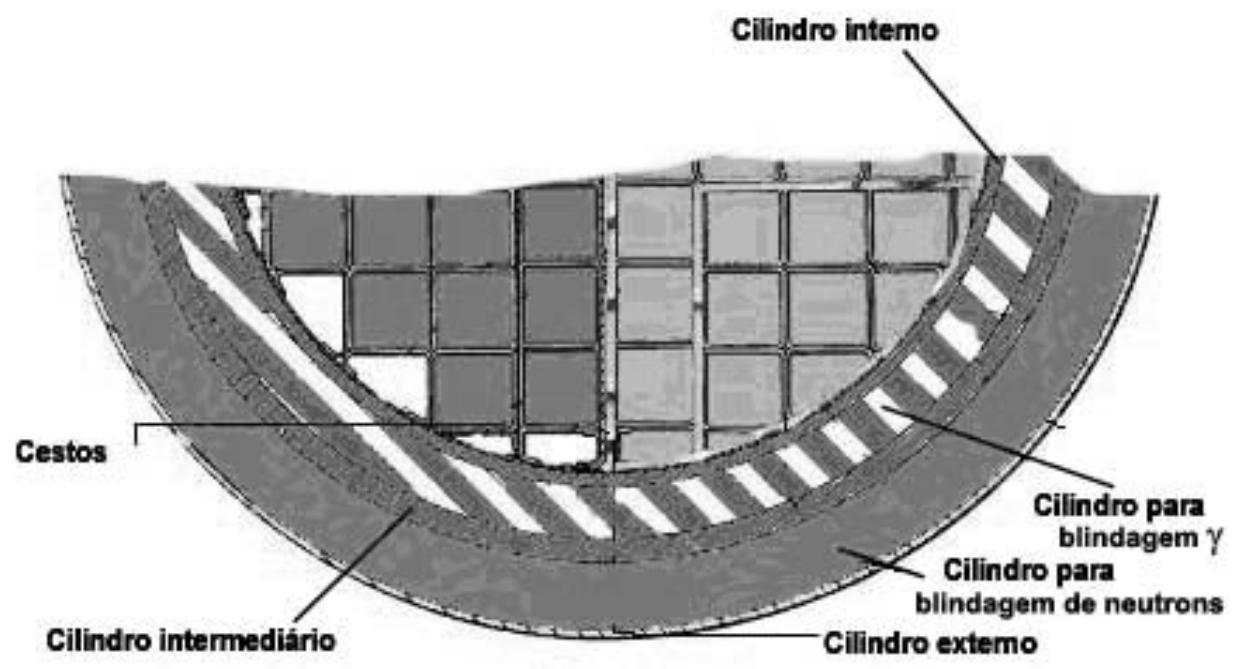

Figura 59 - Esquema de disposição dos cilindros concêntricos componentes de um casco para CNQ-PWR

Fonte: Adaptado de Lusk e Ridihalgh (1987)

Para que ocorra a absorção de nêutrons mais efetiva nas paredes dos cestos internos de aço, pode ser acrescentado boro na liga de aço durante sua fabricação na usina siderúrgica. O cesto serve também como meio que promove a troca de calor por convecção entre o elemento combustível e a superfície do casco, portanto, deve suportar temperaturas no limite de $350^{\circ} \mathrm{C}$ no revestimento do elemento, conforme Matveev et al. (2006). Cestos em aço inoxidável são mais adequados que os de alumínio porque suportam temperaturas mais altas.

Para o revestimento de blindagem de nêutrons, poderá ser utilizado o polietileno de alta densidade puro ou outro tipo de polietileno mais efetivo e que tenha uma densidade maior. A indústria nacional comercializa o polietileno de alta densidade (Dow, 2009) e no exterior, já se produz polietileno combinado com boro e polietileno com lítio (John Caunt Scientific, 2008) que são materiais que também podem ser utilizados como blindagem (SHIELDWERX, 2007). 


\subsubsection{Seleção da quantidade de elementos CNQ para o casco proposto}

Optou-se por casco cilíndrico, de modo que cada casco compreende vários cilindros concêntricos: cilindro interno, outro confeccionado com material para blindar a radiação gama, um cilindro intermediário de aço inoxidável, um com material para blindagem de nêutrons e um cilindro externo de aço inoxidável (Figura 59).

Ao utilizar a Regressão Não Linear na Tabela 12, com auxílio do programa LAB Fit, foram construídas curvas referentes às espessuras da blindagem (APÊNDICE A) e também determinadas as espessuras prováveis para cascos com 16 ou 32 elementos CNQ (Tabela 15), quantidades tipicamente encontradas nos cascos existentes em outros países.

Tabela 15 - Espessura da blindagem contra raios gama e nêutrons após resfriamento do CNQ-PWR, com burnup de $33 \mathrm{GWd} / \mathrm{tU}$, por cinco anos em piscina

\begin{tabular}{c|cc|c|c|c|c}
\cline { 2 - 7 } & \multicolumn{6}{c}{ Espessura $\left(10^{-2} \mathrm{~m}\right)$} \\
\hline \multirow{2}{*}{$\begin{array}{c}\text { Número de } \\
\text { elementos }\end{array}$} & \multicolumn{2}{c}{ Casco de $\mathrm{Pb}$} & \multicolumn{2}{c}{ Casco de Fe } & \multicolumn{2}{c}{ Casco de U } \\
\cline { 2 - 7 } & $e_{2}(\gamma)^{1}$ & $e_{4}(\mathrm{n})^{2}$ & $e_{2}(\gamma)^{1}$ & $e_{4}(\mathrm{n})^{2}$ & $e_{2}(\gamma)^{1}$ & $e_{4}(\mathrm{n})^{2}$ \\
\hline 1 & 9,0 & 9,1 & 22,3 & 8,7 & 5,6 & 6,5 \\
4 & 10,1 & 9,8 & 23,9 & 8,8 & 6,2 & 7,2 \\
8 & 10,6 & 10,0 & 24,8 & 8,9 & 6,6 & 7,9 \\
12 & 11,1 & 10,3 & 25,6 & 9,1 & 6,8 & 8,4 \\
15 & 11,3 & 10,4 & 25,7 & 9,1 & 6,9 & 8,5 \\
16 & 11,4 & 10,4 & 25,8 & 9,1 & 6,9 & 8,5 \\
18 & 11,4 & 10,4 & 25,9 & 9,1 & 7,0 & 8,5 \\
21 & 11,6 & 10,7 & 26,2 & 9,2 & 7,1 & 8,8 \\
24 & 11,7 & 10,8 & 26,3 & 9,3 & 7,1 & 8,8 \\
32 & 12,2 & 11,3 & 26,8 & 9,4 & 7,3 & 9,2 \\
\hline 1 = radiação gama; $2=$ emissão de nêutrons; Pb = chumbo; Fe $=$ ferro; U = urânio (DU); \\
$e_{2}$ - espessura da contenção de gama, $e_{4}-$ espessura da contenção de nêutrons \\
Fonte: Adaptado de Shappert et al. (1998) - valores ajustados
\end{tabular}

Para efeito do presente trabalho considerou-se para o CNQ-PWR um valor adaptado de burnup de $33 \mathrm{GWd} / \mathrm{tU}$ e resfriamento em piscina durante cinco anos.

Foram, ainda, estimadas as massas dos cascos, alturas e diâmetros externos de acordo com as dimensões do elemento CNQ, dos cestos, das espessuras das blindagens e dos revestimentos.

Os valores das espessuras dos revestimentos internos, intermediários e externos do casco variam em função do material utilizado para confeccionar a blindagem contra raios gama e encontram-se na Tabela 16 (Shappert et al., 1998). 
Tabela 16 - Espessuras dos revestimentos interno, intermediário e externo, para confecção dos cascos para CNQ-PWR, com burnup de $33 \mathrm{GWd} / \mathrm{tU}$.

\begin{tabular}{c|c|c|c}
\cline { 2 - 4 } & \multicolumn{3}{c}{ Espessura do revestimento $\left(10^{-2} \mathrm{~m}\right)$} \\
\hline Material & $e_{1}$ & $e_{3}$ & $e_{5}$ \\
\hline Chumbo & 3,8 & 5,1 & 1,9 \\
Ferro & 1,0 & 1,0 & 1,9 \\
Urânio (DU) & 1,9 & 5,1 & 1,9 \\
\hline
\end{tabular}

$e_{1}=$ interno, $e_{3}=$ intermediário, $e_{5}=$ externo

Fonte: Adaptado de Shappert et al. (1998) - valores ajustados

Os diâmetros das cavidades nas quais devem ser introduzidos os cestos com os elementos combustíveis queimados foram calculados levando-se em conta a disposição geométrica dos elementos CNQ e são apresentados na Tabela 17.

Tabela 17 - Valores dos diâmetros da cavidade do casco para CNQ-PWR, com burnup de $33 \mathrm{GWd} / \mathrm{tU}$.

\begin{tabular}{c|c|c|c}
\hline $\begin{array}{c}\text { Casco (quantidade de } \\
\text { elementos CNQ) }\end{array}$ & $\begin{array}{c}\text { Diâmetro } \\
\left(10^{-2} \mathrm{~m}\right)\end{array}$ & $\begin{array}{c}\text { Casco (quantidade de } \\
\text { elementos CNQ) }\end{array}$ & $\begin{array}{c}\text { Diâmetro } \\
\left(10^{-2} \mathrm{~m}\right)\end{array}$ \\
\hline C1 & 34 & $\mathrm{C} 16$ & 133,5 \\
C4 & 67 & $\mathrm{C} 18$ & 137,5 \\
C8 & 97 & $\mathrm{C} 21$ & 137,5 \\
C12 & 118 & $\mathrm{C} 24$ & 149 \\
C15 & 127 & $\mathrm{C} 32$ & 170 \\
\hline
\end{tabular}

As densidades dos materiais utilizados no presente estudo, para a confecção dos cascos, são mostradas na Tabela 18.

Tabela 18 - Densidades dos materiais possíveis para a confecção dos cascos para CNQPWR

\begin{tabular}{lc}
\cline { 2 - 2 } & $\begin{array}{c}\text { Densidade } \\
\left(\mathrm{g} / \mathrm{cm}^{3}\right)\end{array}$ \\
\hline Ferro & 7,87 \\
Polietileno* & 0,96 \\
Chumbo & 11,34 \\
Urânio $($ DU) & 19,10 \\
\hline *Polietileno de alta densidade
\end{tabular}

Para uma primeira estimativa da massa do casco e os cilindros concêntricos internos, levou-se em conta as dimensões apresentadas na Figura 60. 


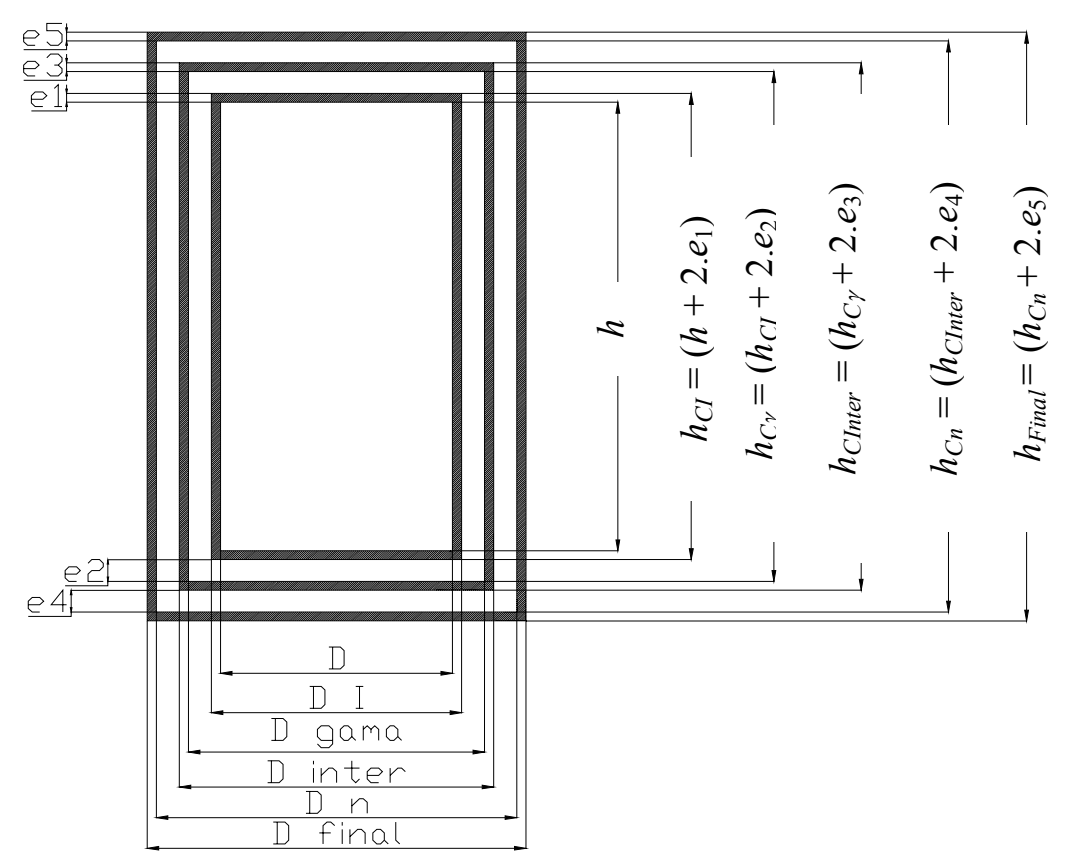

Onde: $e_{1}$ - espessura do revestimento interno, conforme Tabela 16

$e_{2}$ - espessura da blindagem de raios gama, conforme Tabela 15

$e_{3}$ - espessura do revestimento intermediário, conforme Tabela 16

$e_{4}$ - espessura da blindagem de nêutrons, conforme Tabela 15

$e_{5}$ - espessura do revestimento externo, conforme Tabela 16

$D$ - diâmetro da cavidade do cesto, conforme Tabela 17

$D_{I}$ - diâmetro externo do cilindro interno $D_{I}=2 . e_{1}+D$

$D_{g}$ - diâmetro do cilindro- blindagem gama $D_{\gamma}=2 . e_{2}+D_{I}$

$D_{\text {Inter }}$ - diâmetro do cilindro intermediário $D_{\text {Inter }}=2 . e_{3}+D_{\gamma}$

$D_{n}$ - diâmetro do cilindro de contenção de nêutrons $D_{n}=2 . e_{4}+D_{\text {Inter }}$

$D_{\text {Final }}$ - diâmetro do cilindro externo (diâmetro do casco) $D_{\text {Final }}=2 . e_{5}+D_{n}$

$h$ - altura do elemento CNQ, igual a 4,835 m (adotada como altura da cavidade)

$h_{C I}$ - altura do cilindro interno; $h_{C I}=\left(h+2 . e_{1}\right)$

$h_{C \gamma}-$ altura do cilindro de blindagem de raios gama; $h_{C \gamma}=\left(h_{C I}+2 . e_{2}\right)$

$h_{\text {CInter }}$ - altura do cilindro intermediário; $h_{\text {CInter }}=\left(h_{C \gamma}+2 . e_{3}\right)$

$h_{C n}$ - altura do cilindro de blindagem de nêutrons; $h_{C n}=\left(h_{\text {CInter }}+2 . e_{4}\right)$

$h_{\text {Final }}$ - altura do cilindro externo (altura do casco); $h_{\text {Final }}=\left(h_{C n}+2 . e_{5}\right)$

Figura 60 - Dimensões básicas de um casco para CNQ-PWR.

Uma estimativa do volume dos cestos foi feita multiplicando-se a área das bases dos cilindros pelas alturas. A área foi calculada com auxílio do programa Autocad 2008, para as diferentes quantidades de elementos CNQ considerados neste estudo. Foram usadas as equações seguintes: 
Volume do cilindro de revestimento interno:

$$
V_{I}=\pi \frac{\left(D_{I}^{2}-D^{2}\right)}{4} \cdot h+2 \cdot\left(\pi \frac{D_{I}^{2}}{4}\right) \cdot e_{1}\left(\mathrm{~cm}^{3}\right)
$$

Volume do cilindro para blindagem da radiação gama:

$$
V_{\gamma}=\pi \frac{\left(D_{\gamma}{ }^{2}-D_{I}{ }^{2}\right)}{4} \cdot h_{C I}+2 .\left(\pi \frac{D_{\gamma}^{2}}{4}\right) \cdot e_{2}\left(\mathrm{~cm}^{3}\right)
$$

Volume do cilindro de revestimento intermediário:

$$
V_{\text {Inter }}=\pi \frac{\left(D_{\text {Inter }}{ }^{2}-D_{\gamma}{ }^{2}\right)}{4} \cdot h_{C \gamma}+2 .\left(\pi \frac{D_{\text {Inter }}^{2}}{4}\right) \cdot e_{3}\left(\mathrm{~cm}^{3}\right)
$$

Volume do cilindro para blindagem de nêutrons:

$$
V_{n}=\pi \frac{\left(D_{n}^{2}-D_{\text {Inter }}^{2}\right)}{4} \cdot h_{\text {CInter }}+2 .\left(\pi \frac{D_{n}^{2}}{4}\right) \cdot e_{4}\left(\mathrm{~cm}^{3}\right)
$$

Volume do cilindro de revestimento externo:

$$
V_{\text {Ext }}=\pi \frac{\left(D_{\text {Final }}{ }^{2}-D_{n}^{2}\right)}{4} \cdot h_{C n}+2 \cdot\left(\pi \frac{D_{\text {Final }}^{2}}{4}\right) \cdot e_{5}\left(\mathrm{~cm}^{3}\right)
$$

O material adotado para a realização dos cálculos da massa foi o aço-carbono, mas para a construção dos cestos deverá ser considerada a liga aço inoxidável com boro. Portanto, a massa dos cestos $m_{c e}$ será:

$$
m_{c e}=V_{c e} \times d_{c e}(k g)
$$

Onde: $V_{c e}=$ volume do cesto e $d_{c e}=$ densidade do cesto

E, a massa dos cascos vazios:

$$
M_{c}=\sum_{i=I}^{E x t}\left(V_{i} \times \underset{\text { materiais }}{d}\right)+m_{c e}(k g)
$$

A massa do elemento CNQ utilizada nos cálculos foi de $m_{C N Q}=832 \mathrm{~kg}$ (massa do elemento de Angra 2).

Nas Tabelas 19 e 20 são apresentados a massa, diâmetro externo e altura dos cascos em razão da quantidade de elementos de CNQ-PWR. Os cálculos completos encontram-se no APÊNDICE B. 
Tabela 19 - Massa dos cascos para CNQ-PWR, com burnup de $33 \mathrm{GWd} / \mathrm{tU}$ e cinco anos de resfriamento.

\begin{tabular}{c|c|c|c|c|c|c}
\hline \multirow{2}{*}{$\begin{array}{c}\text { Casco } \\
\text { quantidade de } \\
\text { elementos CNQ) }\end{array}$} & \multicolumn{3}{c|}{$\begin{array}{c}\text { Massa do casco sem os elementos } \\
\text { CNQ }(\mathrm{kg})\end{array}$} & \multicolumn{3}{c}{$\begin{array}{c}\text { Massa do casco com todos os } \\
\text { elementos CNQ (kg) }\end{array}$} \\
\cline { 2 - 7 } & $\mathrm{Pb}$ & $\mathrm{Fe}$ & $\mathrm{U}$ & $\mathrm{Pb}$ & $\mathrm{Fe}$ & $\mathrm{U}$ \\
\hline $\mathrm{C} 1$ & 18621 & 22342 & 14800 & 19453 & 23174 & 15632 \\
$\mathrm{C} 4$ & 33537 & 37755 & 28051 & 36865 & 41083 & 31379 \\
$\mathrm{C} 8$ & 47936 & 52527 & 41717 & 54592 & 59183 & 48374 \\
$\mathrm{C} 12$ & 59381 & 63790 & 51836 & 69365 & 73774 & 61820 \\
$\mathrm{C} 15$ & 64772 & 68802 & 56687 & 77252 & 81282 & 69166 \\
$\mathrm{C} 16$ & 68319 & 72096 & 59606 & 81630 & 85408 & 72918 \\
$\mathrm{C} 18$ & 70585 & 74531 & 62276 & 85561 & 89508 & 77252 \\
$\mathrm{C} 21$ & 72053 & 76032 & 63513 & 89525 & 93504 & 80985 \\
$\mathrm{C} 24$ & 78618 & 82232 & 69168 & 98585 & 102200 & 89136 \\
$\mathrm{C} 32$ & 93081 & 95282 & 81694 & 119705 & 121906 & 108317 \\
\hline
\end{tabular}

$\mathrm{Pb}=$ chumbo; $\mathrm{Fe}=$ ferro; $\mathrm{U}=$ urânio (DU)

Tabela 20 - Diâmetro externo e altura dos cascos para CNQ-PWR, com burnup de $33 \mathrm{GWd} / \mathrm{tU}$ e cinco anos de resfriamento.

\begin{tabular}{c|c|c|c|c|c|c}
\hline \multirow{2}{*}{$\begin{array}{c}\text { Casco } \\
\text { (quantidade de } \\
\text { elementos CNQ) }\end{array}$} & \multicolumn{3}{|c|}{ Diâmetro externo (m) } & \multicolumn{3}{c}{ Altura (m) } \\
\cline { 2 - 7 } & $\mathrm{Pb}$ & $\mathrm{Fe}$ & $\mathrm{U}$ & $\mathrm{Pb}$ & $\mathrm{Fe}$ & $\mathrm{U}$ \\
\hline $\mathrm{C} 1$ & 0,92 & 1,04 & 0,76 & 5,41 & 5,53 & 5,26 \\
$\mathrm{C} 4$ & 1,28 & 1,40 & 1,12 & 5,45 & 5,57 & 5,28 \\
$\mathrm{C} 8$ & 1,60 & 1,73 & 1,44 & 5,46 & 5,59 & 5,30 \\
$\mathrm{C} 12$ & 1,82 & 1,95 & 1,66 & 5,48 & 5,61 & 5,32 \\
$\mathrm{C} 15$ & 1,92 & 2,04 & 1,76 & 5,49 & 5,61 & 5,32 \\
$\mathrm{C} 16$ & 1,99 & 2,11 & 1,82 & 5,49 & 5,61 & 5,32 \\
$\mathrm{C} 18$ & 2,03 & 2,15 & 1,86 & 5,49 & 5,61 & 5,32 \\
$\mathrm{C} 21$ & 2,04 & 2,16 & 1,87 & 5,50 & 5,62 & 5,33 \\
$\mathrm{C} 24$ & 2,16 & 2,28 & 1,99 & 5,50 & 5,63 & 5,33 \\
$\mathrm{C} 32$ & 2,38 & 2,50 & 2,21 & 5,52 & 5,64 & 5,34 \\
\hline
\end{tabular}

$\mathrm{Pb}=$ chumbo; $\mathrm{Fe}=$ ferro; $\mathrm{U}=$ urânio (DU)

Quanto ao arranjo dos elementos CNQ dentro dos cascos, foi verificada a disposição geométrica interna e a quantidade de elementos que o casco poderia armazenar.

Os cascos com 1, 4, 8 e 12 elementos (Figura 61) apresentaram uma relação entre a massa do CNQ e a massa total do casco muito pequena (Tabela 21), ou seja, poderse-ia armazenar poucos elementos por casco, portanto foram desconsiderados. 


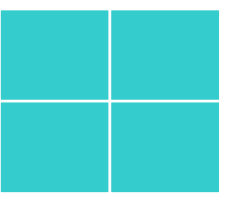

1 elemento

4 elementos

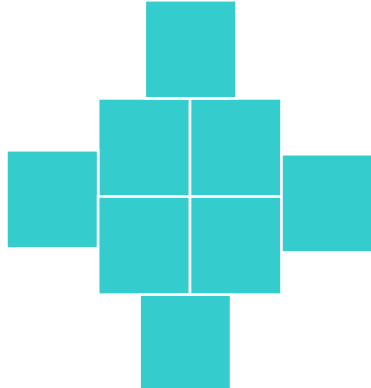

8 elementos

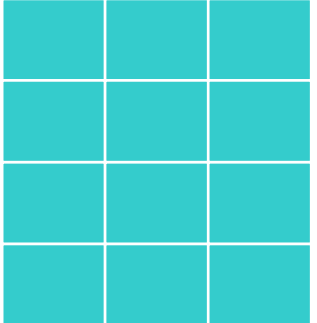

12 elementos

Figura 61 - Arranjos geométricos da distribuição dos elementos CNQ-PWR

(1, 4, 8 e 12 elementos)

Tabela 21 - Relação massa do combustível/massa total do casco para CNQ-PWR, com burnup de $33 \mathrm{GWd} / \mathrm{tU}$ e cinco anos de resfriamento.

\begin{tabular}{c|c|c|c}
\hline Casco & $\mathrm{Pb}$ & $\mathrm{Fe}$ & $\mathrm{U}$ \\
\hline $\mathrm{C} 1$ & $4 \%$ & $4 \%$ & $5 \%$ \\
$\mathrm{C} 4$ & $9 \%$ & $8 \%$ & $11 \%$ \\
$\mathrm{C} 8$ & $12 \%$ & $11 \%$ & $14 \%$ \\
$\mathrm{C} 12$ & $15 \%$ & $14 \%$ & $16 \%$ \\
$\mathrm{C} 15$ & $16 \%$ & $15 \%$ & $18 \%$ \\
$\mathrm{C} 16$ & $17 \%$ & $16 \%$ & $19 \%$ \\
$\mathrm{C} 18$ & $18 \%$ & $17 \%$ & $20 \%$ \\
$\mathrm{C} 21$ & $20 \%$ & $19 \%$ & $22 \%$ \\
$\mathrm{C} 24$ & $21 \%$ & $20 \%$ & $23 \%$ \\
$\mathrm{C} 32$ & $22 \%$ & $22 \%$ & $24 \%$ \\
\hline
\end{tabular}

$\mathrm{Pb}=$ chumbo; $\mathrm{Fe}=$ ferro; $\mathrm{U}=$ urânio (DU).

Observou-se também que cascos com 15 ou 18 elementos (Figura 62) proporcionam um arranjo interno com geometria deficiente, por este motivo também foram desconsiderados.

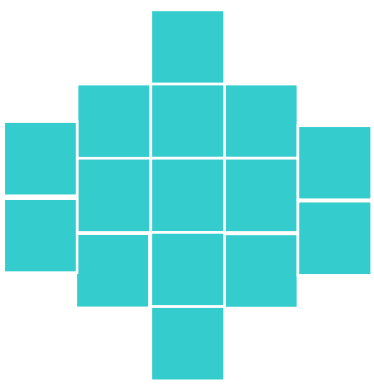

15 elementos

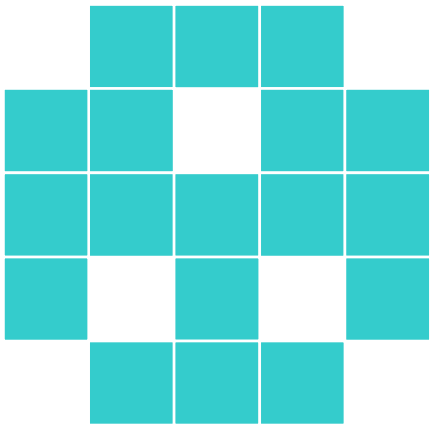

18 elementos

Figura 62 - Arranjos geométricos da distribuição dos elementos CNQ-PWR (15 e 18 elementos) 
Os cascos para armazenar 16, 21, 24 e 32 elementos CNQ (Figura 63) foram os escolhidos para as três opções de materiais: ferro, chumbo ou urânio exaurido.
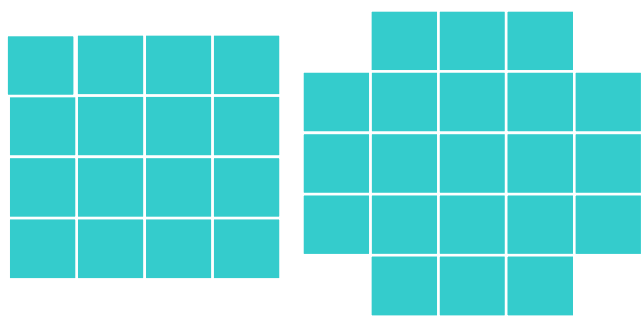

16 elementos

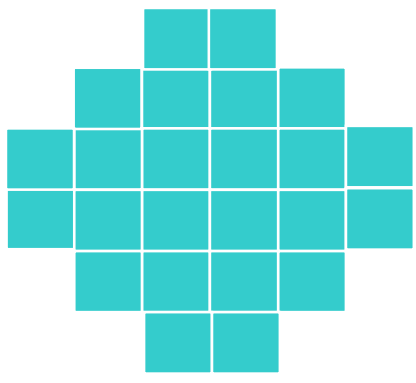

24 elementos

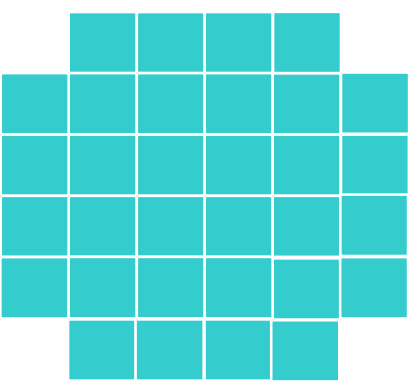

32 elementos

Figura 63 - Arranjos geométricos da distribuição dos elementos de CNQ-PWR

$(16,21,24$ e 32 elementos)

Para decidir sobre qual a melhor alternativa quanto ao número de elementos CNQ a serem abrigados no casco, foi realizada uma análise com auxílio do método chamado Processo Hierárquico Analítico - Analytical Hierarchy Process (AHP). Esse método consiste em comparações entre atributos estabelecidos aos pares e uma escala para avaliar essas comparações. (Saaty, 1980).

Os valores numéricos utilizados e suas respectivas escalas qualitativas são as seguintes:

- 1 - Igualdade

- 3 - Moderada

- 5 - Forte

- 7 - Muito forte

- 9 - Extrema diferença

Valores intermediários $(2,4,6,8)$ também podem ser utilizados.

Foram consideradas as comparações quanto às preferências seguintes:

- As dimensões do casco são extremamente mais importantes que a massa do casco.

Dimensão $/$ massa $=9 / 1$

- As dimensões do casco são fortemente mais importantes que a quantidade de combustível armazenada.

Dimensão / quantidade $=6 / 1$

- A quantidade de combustível armazenado é moderadamente mais importante que a massa total do casco

Quantidade $/$ massa $=3 / 1$ 
O método se apóia em seleção subjetiva de atributos e outra forma de escolha pode ser feita por meio de um consenso de especialistas. Apesar da subjetividade do método, foi realizada a análise, cujos cálculos estão demonstrados no APÊNDICE C, chegou-se à conclusão que a quantidade mais favorável de elementos CNQ por casco é de 21, para os três casos analisados.

Considerando-se assim, 21 elementos CNQ por casco, para um burnup de $33 \mathrm{GWd} / \mathrm{tU}$, resfriamento de 5 anos em piscina, ter-se-ia uma configuração de casco conforme as Tabelas 15, 16 e 17 anteriormente apresentadas, e a disposição como mostra a Figura 64.

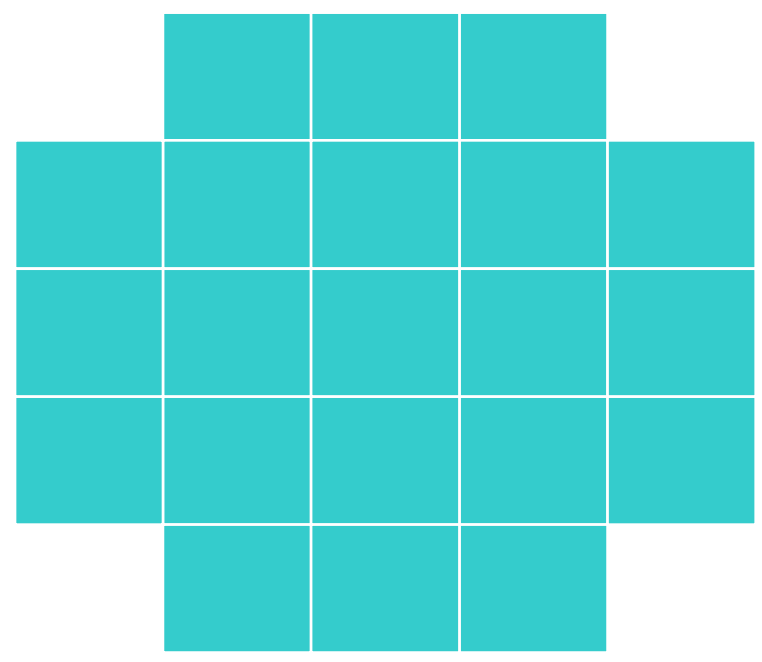

Figura 64 - Configuração dos 21 elementos CNQ-PWR no cesto a ser inserido no casco sugerido na presente tese

Os cascos de chumbo, ferro ou urânio exaurido, com 21 elementos terão diâmetros externos, altura e massas conforme mostra a Tabela 22.

Tabela 22 - Comparativo dimensional entre cascos de chumbo, ferro e urânio (DU) para 21 elementos CNQ-PWR, com burnup de $33 \mathrm{GWd} / \mathrm{tU}$ e cinco anos de resfriamento.

\begin{tabular}{c|c|c|c|c}
\hline Material & $\begin{array}{c}\text { Diâmetro } \\
\text { externo } \\
(\mathbf{m})\end{array}$ & $\begin{array}{c}\text { Altura } \\
\mathbf{( m )}\end{array}$ & $\begin{array}{c}\text { Massa do casco } \\
\text { vazio* } \\
\mathbf{( k g )}\end{array}$ & $\begin{array}{c}\text { Massa do casco } \\
\text { carregado* } \\
\mathbf{( k g )}\end{array}$ \\
\hline Chumbo & 2,04 & 5,50 & 72100 & 89600 \\
Ferro & 2,16 & 5,62 & 76000 & 93500 \\
Urânio (DU) & 1,87 & 5,33 & 63600 & 81000 \\
\hline
\end{tabular}

* valor aproximado 


\subsubsection{Nível de radiação com vistas ao transporte e armazenagem seca de CNQ-PWR}

Um Programa de Proteção Radiológica deve ser estabelecido para o transporte (Plano de Transporte) e armazenagem de cascos com CNQ. A natureza e extensão das medidas a serem empregadas no programa devem estar relacionadas com a magnitude e probabilidade de exposição à radiação. O Requisito de Segurança TS-R-1 (2005), da IAEA, estabelece que o transporte e armazenagem de materiais radioativos devem possuir, no caso das exposições ocupacionais resultantes de atividades de transporte:

a) um programa de avaliação das doses por meio de controle no local de trabalho ou monitoração individual, se esta se situar entre 1 e $6 \mathrm{mSv}$ em um ano e;

b) monitoração individual quando for superior a $6 \mathrm{mSv}$ em um ano.

Para a monitoração individual ou do local de trabalho devem ser mantidos registros adequados.

O mesmo requisito TS-R-1 da IAEA define como nível de radiação a taxa de dose correspondente expressa em milisieverts por hora $(\mathrm{mSv} / \mathrm{h})$ e define ainda que o nível de radiação, em qualquer ponto da superfície externa de um casco não deve ultrapassar $2 \mathrm{mSv} / \mathrm{h}$, até $10 \mathrm{mSv} / \mathrm{h}$, no caso de uso exclusivo.

De acordo com a Norma CNEN 5.01, o embalado Tipo B (embalagem projetada para suportar os efeitos resultantes de um acidente de transporte com o grau de retenção da integridade de contenção e blindagem exigidos pela norma) para transporte de material físsil deve ser projetado de modo a manter, se submetido aos ensaios prescritos na norma, blindagem suficiente para assegurar que o nível de radiação a um metro $(1 \mathrm{~m})$ da superfície externa do embalado não exceda $10 \mathrm{mSv} / \mathrm{h}$.

O regulamento 10 CFR 71.47 (USNRC, 2009) estabelece que, para o transporte, o nível de radiação:

a) na superfície do casco não deverá ultrapassar $2 \mathrm{mSv} / \mathrm{h}$;

b) a uma distância de $2 \mathrm{~m}$ do veículo transportador não deve ultrapassar $0,1 \mathrm{mSv} / \mathrm{h}$. Como no transporte, o casco não é coberto, a distância deverá ser de $2 \mathrm{~m}$ da superfície do casco.

As espessuras apresentadas nas Tabelas 10 a 15 foram calculadas de forma que o nível de radiação não ultrapasse $0,09 \mathrm{mSv} / \mathrm{h}$ para raios gama e $0,01 \mathrm{mSv} / \mathrm{h}$ para nêutrons, para distâncias de 3,05m (10pés) a partir do eixo central do casco na posição vertical, 
conforme recomendado por Shappert et al. (1998). Portanto, para o nível de radiação estabelecido para a distância de $2 \mathrm{~m}$ da superfície do casco ou da parte exterior da tampa e do fundo, e conforme a Tabela 20, a distância considerada, para o casco na posição vertical, será:

a) 3,02m a partir do eixo central para casco confeccionado em chumbo;

b) 3,08m a partir do eixo central para casco confeccionado em ferro; e,

c) 2,95m a partir do eixo central para casco confeccionado em urânio exaurido.

Deverá ser atendida, também, a Norma CNEN 3.01 (2005), nos limites de doses anuais efetivas para trabalhadores $(20 \mathrm{mSv})$ e público $(1 \mathrm{mSv})$.

\subsubsection{Interação da radiação com os materiais utilizados para a construção do casco}

O polietileno de alta densidade é um material altamente hidrogenado e misturado com boro possui uma densidade de $1,4 \mathrm{~g} / \mathrm{cm}^{3}$. O boro atenua os nêutrons térmicos e reduz o nível de captura dos raios gama, ao passo que a alta concentração de hidrogênio termaliza os nêutrons rápidos. Porém, os nêutrons capturados pelo boro resultam em raios $\gamma$ com energia de $0,42 \mathrm{MeV}$, e tal fato não ocorre com o polietileno misturado com lítio. O lítio, no entanto, é menos efetivo que o boro para a captura de nêutrons térmicos. Ao utilizar lítio na mistura com o polietileno de alta densidade, a espessura deve ser maior que a de polietileno borado. A densidade do polietileno com lítio é de $1,06 \mathrm{~g} / \mathrm{cm}^{3}$. A densidade do polietileno de alta densidade considerada nos cálculos do presente estudo é de $0,96 \mathrm{~g} / \mathrm{cm}^{3}$.

Se forem utilizados cascos de ferro é necessário analisar a ação dos nêutrons lentos, pois o ferro contém o isótopo ${ }^{58} \mathrm{Fe}$, na proporção de $0,28 \%$, que pode ser ativado por esses nêutrons transformando-se em ${ }^{59} \mathrm{Fe}$ radioativo, que possui meia vida de 44,5 dias e emite radiação gama $(\mathrm{E}=1,5 \mathrm{MeV})$ (Komarowskii, 1961).

\subsubsection{Descrição do casco proposto}

De acordo com as considerações e cálculos apresentados anteriormente, sugere-se que:

- Os cascos sejam de aço inoxidável com blindagem de chumbo contra raios gama e polietileno de alta densidade para blindar nêutrons (APÊNDICES D a I). Desconsiderou-se o ferro, pois após irradiação, pode emitir radiação gama. O urânio 
exaurido, por sua vez, além de ter custo maior, é salvaguardado e na forma metálica pode se incendiar em impactos.

- Considerou-se duas tampas no topo superior: a interna aparafusada e a externa soldada (APÊNDICE E). O fundo do casco é uma placa fixada e soldada durante a fabricação do casco.

- A drenagem do líquido deve ser feita por meio de um dreno localizado na parte inferior do casco e a inserção do gás inerte, por intermédio de uma válvula localizada na tampa interna da parte superior do casco (APÊNDICES F e H).

- A carcaça interna engloba o revestimento interno, a blindagem contra raios gama e o revestimento intermediário, e a carcaça externa engloba a blindagem contra nêutrons e revestimento externo (APÊNDICES D, E e G).

- O cesto deverá ser de aço inoxidável, com boro disperso na sua composição e com uma folga de $2 \mathrm{~mm}$ entre as paredes, cuja espessura é de 1,5mm (APÊNDICE I).

- Quanto às dimensões, o casco deverá possuir altura total de 5,50m, diâmetro externo de 2,04m e largura máxima total de 2,40m. Um desenho básico do casco está apresentado na Figura 65 e mais detalhes são mostrados nos APÊNDICES D até I.

- A massa do casco vazio deverá ser de, aproximadamente, $72.100 \mathrm{~kg}$ e quando carregado com os 21 elementos CNQ-PWR, aproximadamente, 90.000kg (Tabela 22). 


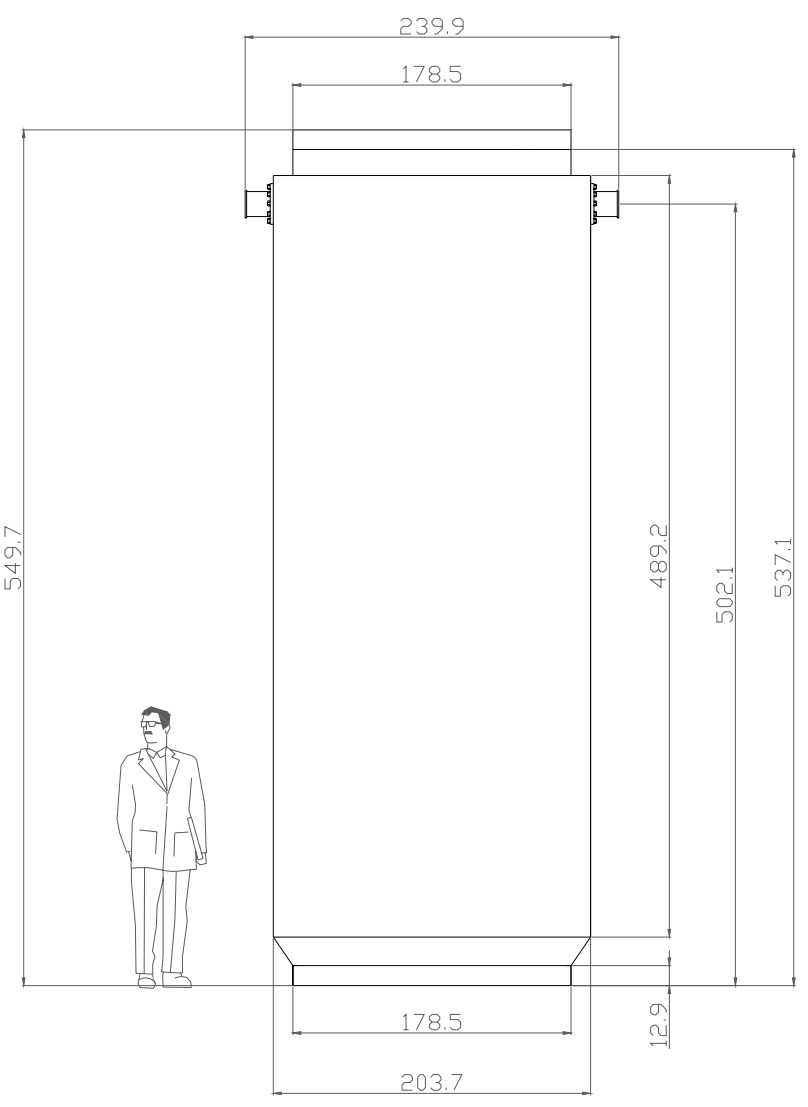

Figura 65 - Casco de armazenagem para 21 elementos CNQ-PWR (dimensões em $10^{-2} \mathrm{~m}$ )

\subsubsection{Processo de qualificação do casco}

Qualquer que seja o tipo de casco de armazenagem e transporte adotado é recomendado que este deva passar, durante o projeto, a construção e aceitação de protótipos, por: análises estruturais, análise térmica, análise de segurança e criticalidade feitos por especialistas de cada área, assim como o licenciamento. Para o primeiro casco construído, deve ser verificado o nível de dose na superfície externa.

\subsubsection{Análise estrutural}

Para a realização da análise estrutural do casco não existe uma metodologia ou um código de computação que possa ser aplicado a todos os elementos do casco. A análise é realizada por partes e deve levar em conta as condições normais de transporte e armazenagem e, também, condições hipotéticas de acidentes.

Por causa da complexidade do casco, a análise estrutural deve ser feita com auxílio de computador por meio de método de elementos finitos, podendo, por exemplo, 
serem aplicados os códigos NASTRAN ou ANSYS. Deve ser dada atenção especial para duas situações: cargas resultantes de impactos e resistência da estrutura a esses impactos.

Os limites de tensão dos materiais do casco devem ser especificados segundo normas, por exemplo, a Norma ASME (2007). No caso de utilização de novos materiais, as propriedades para condição normal e de um acidente hipotético devem ser determinadas. Como o material para a confecção da parede do casco sugerido nesta tese envolve aço, chumbo e polietileno, deve ser avaliada a tensão resultante do impacto interno chumboaço, no caso de uma queda hipotética. O chumbo inserido como blindagem contra raios $\gamma$, trabalha como se estivesse colado ao aço, proporcionando melhor condução térmica entre as camadas de aço. Materiais dúcteis são preferidos para os componentes estruturais, pois podem absorver grande quantidade de energia em um impacto, sem levar à falha imediata do componente.

As tampas, interna e externa, têm a mesma composição (chumbo e polietileno) que o corpo do casco, por isso vale o descrito anteriormente, também.

Os anéis de vedação utilizados no fundo e na tampa, normalmente, são verificados mediante ensaios de estanqueidade, antes e depois da realização de ensaios de queda. Isso é válido para a tampa interna do casco, a tampa que cobre o dreno e a tampa que cobre a válvula de preenchimento.

$\mathrm{O}$ cesto precisa acomodar o CNQ, manter sua integridade e arranjo assegurando a subcriticalidade em todas as condições de transporte e armazenagem. Durante o desenvolvimento do projeto do cesto é necessário assegurar a absorção de nêutrons, analisando-se as possíveis deformações que possam surgir e as mudanças na geometria que possam afetar a manutenção da subcriticalidade.

\subsubsection{Análise térmica}

Todos os cascos que contém material radioativo devem ser avaliados para determinar as temperaturas em operação normal de operação e em situações de acidente.

O objetivo principal do projeto térmico de um casco para CNQ envolve remoção do calor de decaimento dos radionuclídeos de forma passiva e proteção contra o calor de fontes externas. Apesar de que as temperaturas elevadas em um casco não sejam prejudiciais ao público, elas podem comprometer o comportamento de outros requisitos funcionais do casco, como contenção, blindagem ou controle da criticalidade. (Shappert et al., 1998). 
Após a introdução do CNQ no casco, fechamento e retirada da água interna, o calor gerado por decaimento dos radionuclídeos aquece mais comumente, o gás inerte remanescente no interior do casco e provoca o aumento da temperatura e da pressão interna. O documento Regulatory Guide 3.54 (USRNC, 1999) traz um guia para a determinação da quantidade de calor de decaimento liberado no CNQ. No ANEXO A são apresentadas tabelas para a taxa de geração calor de decaimento do CNQ com a contribuição do calor gerado, separadamente, pelo decaimento dos actinídeos, produtos de fissão e elementos leves. As tabelas apresentam o valor da geração de calor após o tempo de resfriamento do CNQ na piscina, para burnups de 25, 30, 35 e $40 \mathrm{GWd} / \mathrm{tU}$ e para potências específicas do combustível de 12,28 e $40 \mathrm{~kW} / \mathrm{kgU}$.

Ao controlar a dissipação do calor gerado dentro do casco por meio da convecção natural, a temperatura do conjunto atinge um regime permanente, permitindo o início do processo de retirada do ar e formação de vácuo para posterior pressurização com o gás inerte.

O ar é retirado por meio de uma bomba de vácuo de vazão constante. À medida que o ar flui para fora do casco, a pressão interna é reduzida até atingir um valor próximo a 0,3bar. Nessa situação, a temperatura do casco se reduz, apesar da presença do calor de decaimento do CNQ. Com a remoção do calor por convecção natural, associada com a retirada do ar quente do interior do casco, a temperatura atinge um valor no qual tende a ficar constante. Neste ponto, a bomba de vácuo deve ser desligada para início da pressurização com o gás inerte.

A pressurização do casco se inicia com a injeção do gás inerte a uma vazão constante. Conforme a massa do gás aumenta no interior do casco, a pressão se eleva até atingir o valor estipulado pelo projeto (admite-se uma pressão de 1,5bar). A temperatura do gás dentro do casco aumenta com o calor gerado pelo decaimento dos produtos de físsão do CNQ. Após a pressurização do casco, a temperatura do gás se estabiliza por convecção natural com o ar ambiente.

Deve ser realizada uma análise de sensibilidade do comportamento térmico do casco com relação à influência da temperatura do ar ambiente, prevendo-se o que pode ocorrer no caso de aumento exagerado na temperatura ambiente e, se for necessário, fazer resfriamento por intermédio de sistemas de ar-condicionado, prevendo, contudo possíveis falhas. As análises podem ser realizadas partindo-se da condição nominal de operação e a temperatura do ar, que pode atingir até $50^{\circ} \mathrm{C}$ (condição de extremo calor ambiente considerando-se o casco já fechado exposto ao ambiente sem outra proteção física) 
Para o projeto, será considerada a temperatura indicada por Shapovalov (2006), ou seja, a superfície externa do casco não deve ultrapassar de $85^{\circ} \mathrm{C}$.

A vedação do casco é um componente crítico quanto à temperatura, os anéis de vedação podem ser metálicos e que resistam a uma temperatura maior que os produtos de vedação elastoméricos. O ponto de fusão da prata, por exemplo, que às vezes é utilizada como material componente dos produtos de vedação mecânica, é de $907^{\circ} \mathrm{C}$, tem excelente coeficiente de transmissão de calor auxiliando a convecção do calor com o ambiente. $\mathrm{O}$ projeto térmico deve levar em conta a capacidade do cesto se manter íntegro e não sofrer deformação induzida pelo calor que possa causar criticalidade nuclear do conteúdo físsil do CNQ (Shappert et al., 1998).

O projeto da blindagem do casco deve prever variações dimensionais causadas pela expansão térmica e mudança de fase dos materiais. $\mathrm{O}$ chumbo tem baixo ponto de fusão $\left(327^{\circ} \mathrm{C}\right)$ e em caso de acidente postulado, que envolva temperaturas de $800^{\circ} \mathrm{C}$, pode fundir e por aumento da pressão interna pode colapsar o casco, embora ainda seja o mais indicado e mais barato como material de blindagem. Apesar dos inconvenientes, no presente estudo, para a construção do casco, o chumbo foi considerado assim mesmo.

Outra possibilidade seria usar urânio exaurido, mas esse material é de difícil aquisição, é salvaguardado, tem um preço muito alto comparado ao chumbo e aço, e pode se inflamar sob impacto caso a temperatura exceda $600^{\circ} \mathrm{C}$ (World Health Organization, 2003).

Válvulas de pressão e drenos devem resistir à pressão interna e ao aumento de pressão por causa do aumento de temperatura em caso de acidente.

$\mathrm{Na}$ determinação das propriedades termo-físicas dos materiais utilizados podem ser consultadas referências como Handbook of Thermodynamics Tables and Charts de K. Raznjevic e Thermophysical Properties Research Center de Y.S. Touloukian e C.Y. Yo (Shappert et al., 1998).

\subsubsection{Análise de criticalidade}

A subcriticalidade do casco deverá ser mantida tanto em condições normais de operação, bem como em condições de acidentes.

A necessidade de validação dos cálculos de criticalidade servirá como simulação do que possa ocorrer após a colocação do CNQ no casco. 
Em cascos com mesmo tipo de armazenagem do proposto nesta tese, conforme Matveev et al.(2006) é mostrado que em condições normais de operação, $k_{\text {eff }} \leq 0,3$ e em condições de acidente $k_{\text {eff }}=0,932$, ainda menor que 0,95 como dita documento técnico da IAEA (2007).

Normas como a ANSI/ANS-8.1 - Nuclear Criticality Safety in Operations with Fissionable Materials Outside Reactors (Segurança nuclear quanto à criticalidade em operações com materiais físseis fora dos reatores) e a ANSI/ANS-8.17 - Criticality Safety Criteria for the Handling, Storage, and Transpotation of LWR Fuel Outside Reactors (Critérios de segurança de criticalidade para o manuseio, estocagem e transporte de combustível fora dos reatores) estabelecem práticas, controles e cálculos do $k_{\text {eff }}$ do sistema do CNQ. (Shappert et al., 1998).

Após estabelecer o projeto definitivo, o casco deverá passar por uma análise de criticalidade para confirmar os valores de subcriticalidade nessas duas condições.

Nos Estados Unidos e Reino Unido ocorreram, ao todo, oito acidentes de criticalidade entre 1958 e 1978 (Pruvost; Paxton, 1996). Esses acidentes ocorreram durante processos químicos com soluções aquosas e nenhum em processos mecânicos, armazenagem ou transporte. Nesses acidentes, duas pessoas morreram e 19 ficaram expostas a uma sobre-exposição à radiação. A publicação mais recente do laboratório nacional de Los Alamos (2000) relata outros incidentes na área nuclear, incluindo o de criticalidade ocorrido na planta de fabricação de combustível em Tokaimura, Japão.

\subsubsection{Ensaios físicos}

Após a confecção do protótipo de um casco e antes do início de fabricação em escala industrial, devem ser realizados ensaios físicos específicos como estanqueidade, queda livre, penetração, e resistência térmica, de modo a propiciar a aceitação técnica para o licenciamento.

O programa de ensaios deve obedecer às normas TS-R-1 (IAEA, 2005a) e CNEN 5.01 (CNEN, 1988) e ao código 10 CFR 71 (USNRC, 2009).

Os ensaios mostrados a seguir, a título de exemplo, foram feitos com protótipo de casco para combustível queimado de reatores MTR, em escala 1:2, desenvolvido pelo grupo de estudos do Brasil, Argentina e Chile no campo de provas do CDTN/CNEN-MG e que, futuramente, poderão ser feitos para os cascos aqui propostos. 
A massa do protótipo era $975 \mathrm{~kg}$, vazio e com os simuladores de combustível e amortecedores de impacto, $1.300 \mathrm{~kg}$.

O protótipo possuía as seguintes dimensões:

1) Corpo com tampa interna, diâmetro externo: 650mm, altura: $1000 \mathrm{~mm}$, diâmetro interno: $350 \mathrm{~mm}$.

2) Amortecedores de impacto, diâmetro: $900 \mathrm{~mm}$, altura do amortecedor superior $245 \mathrm{~mm}$ e do inferior, $275 \mathrm{~mm}$. Foram construídos mais dois amortecedores superiores para eventuais reposições.

As coberturas do dreno e do furo superior foram vedadas com dois anéis de aço inoxidável revestidos com prata e foram fixadas com seis parafusos. A tampa interna foi fixada com 24 parafusos e vedada com dois anéis de aço inoxidável revestidos com prata.

\subsubsection{Ensaio de estanqueidade}

Além da determinação das dimensões do casco, o primeiro ensaio a ser realizado é o da estanqueidade no qual o protótipo é imerso em um tanque com água. Esse ensaio é também chamado de ensaio hidráulico da vedação das tampas e coberturas. $\mathrm{O}$ objetivo desse ensaio é verificar a estanqueidade do casco sob uma pressão de água de $1,5 \mathrm{kgf} / \mathrm{cm}^{2}$.

Como alternativa para esse ensaio, no lugar de submergí-lo num tanque com água, pode ser feita a inserção de água sob pressão, através de um orifício feito na tampa, entre os anéis de vedação interno e externo. A água é introduzida por esse orifício até que a pressão atingida seja a do ensaio $\left(1,5 \mathrm{kgf} / \mathrm{cm}^{2}\right)$. O espaço entre os anéis de vedação da tampa fica sob pressão e se ocorrer vazamento como entrada de ar ambiente para dentro do casco, ocasionará uma diminuição na pressão manométrica, invalidando o teste. Na Figura 66 é apresentada uma montagem do teste alternativo de estanqueidade. 


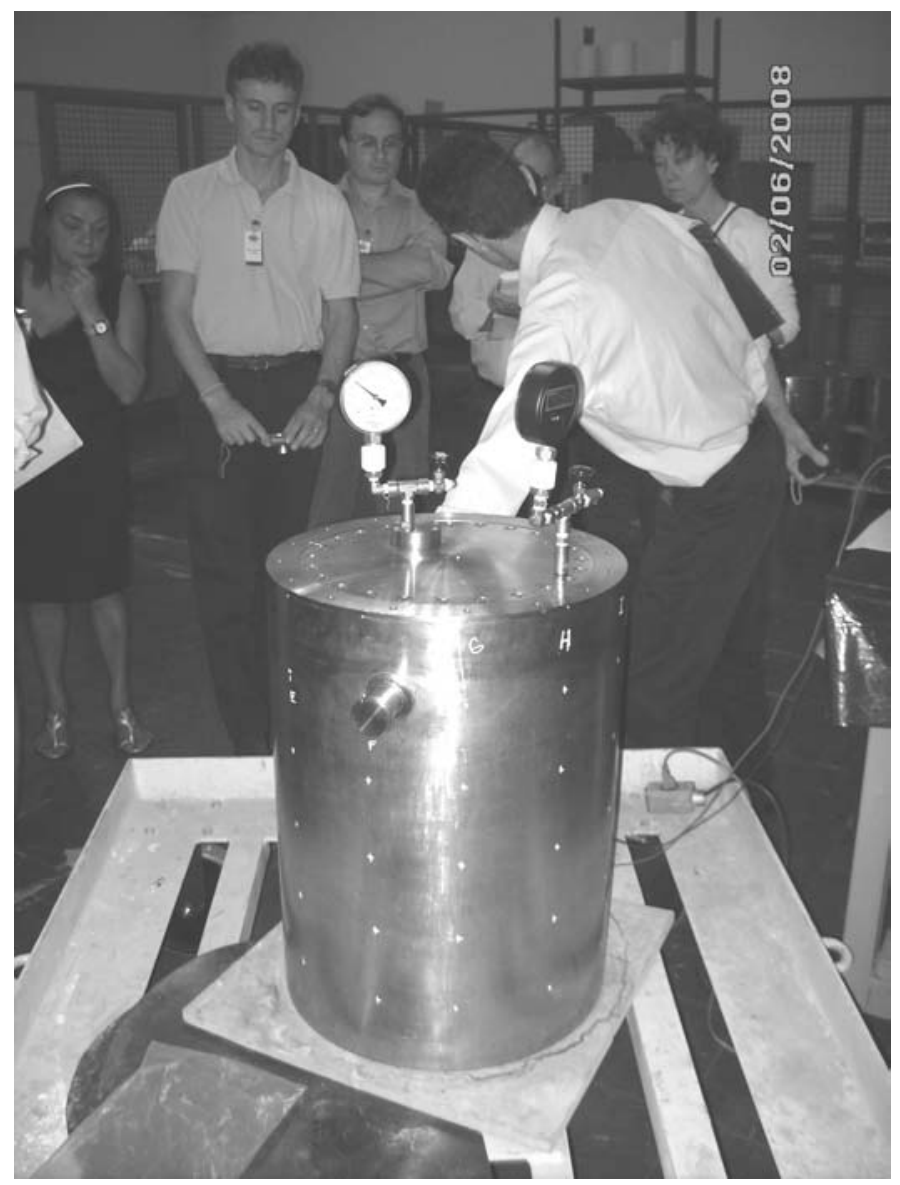

Figura 66 - Montagem alternativa ao teste de estanqueidade de protótipo de casco para CNQ (Local: Campo de testes CDTN/CNEN-MG)

Fonte: Romanato (2008); Foto: Romanato, L. S.

Após atingir a pressão desejada, aguarda-se durante um período de 8 horas, e verifica-se se essa pressão diminui com o passar do tempo.

A norma CNEN 5.01 (1988) estabelece:

"A amostra deve ser imersa sob uma camada de água com, no mínimo, $15 \mathrm{~m}$ de altura, durante um período mínimo de 8 horas, numa posição capaz de acarretar o máximo de dano. Para fins de demonstração, uma pressão manométrica externa no mínimo igual a $150 \mathrm{kPa}\left(1,5 \mathrm{kgf} / \mathrm{cm}^{2}\right)$ deve ser adotada."

\subsubsection{Ensaio de queda}

O mesmo ou outro protótipo, após o teste de estanqueidade, deve ser preparado para o ensaio de queda de 1,20m de altura, em sua pior condição, sobre uma superfície plana. Nesse caso, o protótipo deverá estar preparado como se fosse transportado com limitadores de impacto e carga igual à que será transportada e armazenada, conforme apresentado na Figura 67. 


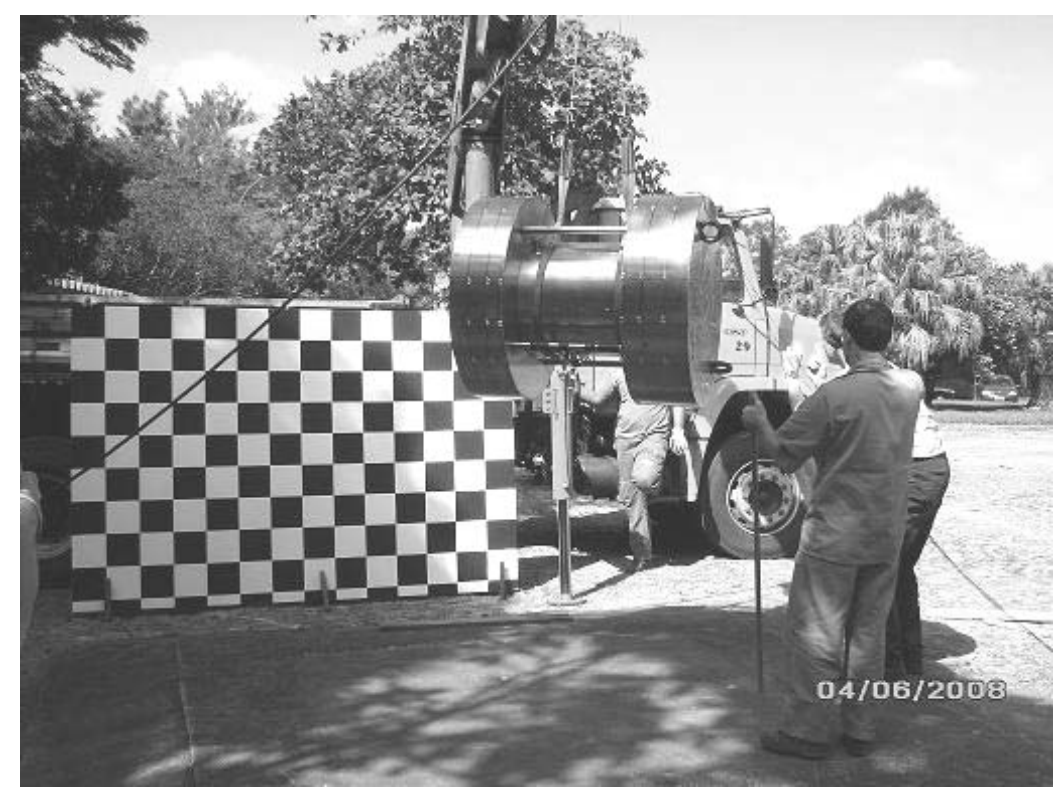

Figura 67 - Teste de queda de 1,2m de altura, de protótipo de casco para CNQ (Local: Campo de testes CDTN/CNEN-MG)

Fonte: Romanato (2008); Foto: Romanato, L. S.

\subsubsection{Ensaio de penetração 1}

Nesse ensaio uma barra circular pontiaguda é solta de uma altura de $1 \mathrm{~m}$, perpendicularmente sobre a superfície do casco.

A norma CNEN 5.01 (1988) estabelece que:

"A amostra deve ser colocada sobre uma superfície rígida, plana e horizontal que não deve se deslocar significativamente durante o ensaio a ser realizado mediante os seguintes procedimentos: a) uma barra de aço com uma massa de $6 \mathrm{~kg}$ e com uma extremidade hemisférica com $3,2 \mathrm{~cm}$ de diâmetro é deixada cair, com o seu eixo verticalmente orientado, no centro da parte mais frágil da amostra, de modo que, caso a barra penetre suficientemente na amostra, esta atinja o sistema de contenção; as deformações da barra devem ser desprezíveis após o ensaio e; b) a altura de queda da barra de aço, da sua extremidade inferior até a superficie externa da amostra, deve ser de $1 \mathrm{~m}$ ".

Na Figura 68 é mostrado o teste de queda de uma barra pontiaguda sobre o casco. 


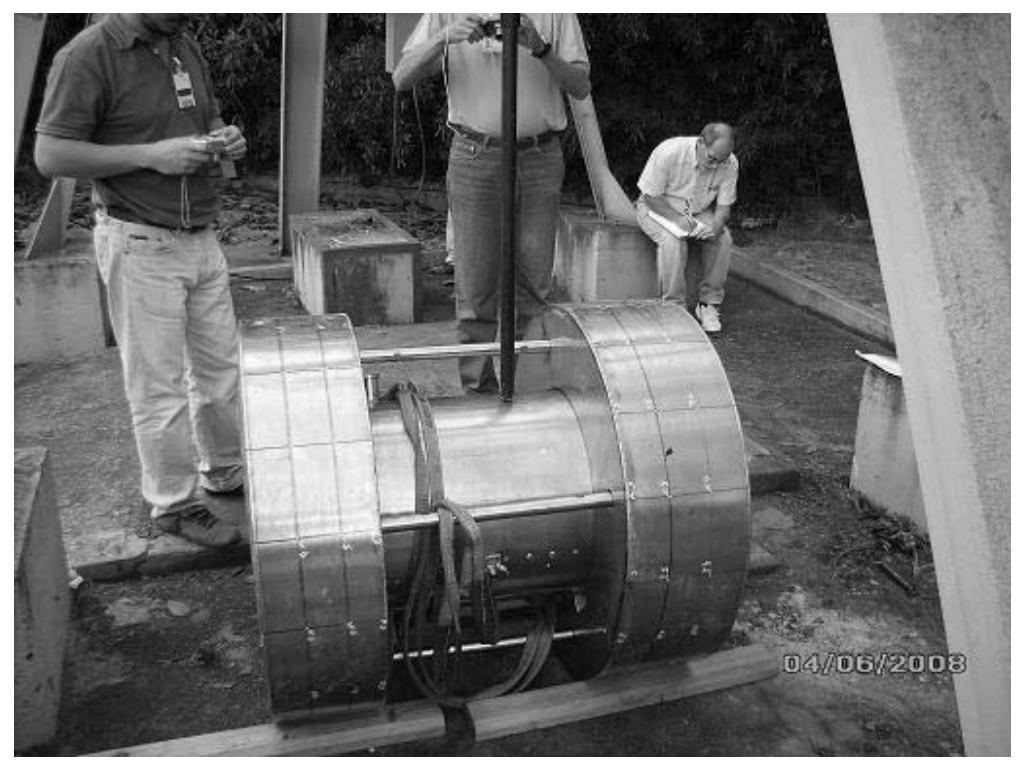

Figura 68 - Teste de queda de barra pontiaguda de uma altura de $1 \mathrm{~m}$ sobre protótipo de casco para CNQ (Local: Campo de testes CDTN-CNEN/MG)

Fonte: Romanato (2008); Foto: Romanato, L. S.

\subsubsection{Ensaio de penetração 2}

Esse ensaio é o de queda do protótipo do casco sobre uma barra de aço, como é mostrado na Figura 69.

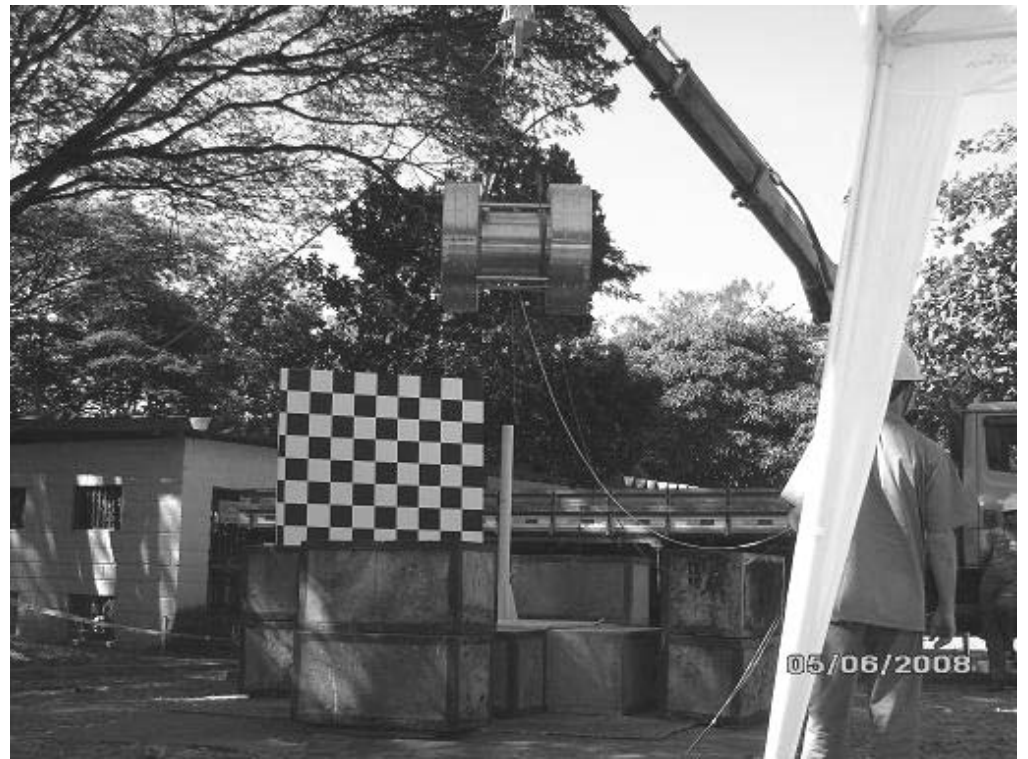

Figura 69 - Teste de queda de $1 \mathrm{~m}$ de altura de protótipo de casco para CNQ sobre uma barra pontiaguda (Local: Campo de testes CDTN/CNEN-MG)

Fonte: Romanato (2008); Foto: Romanato, L.S.

A norma CNEN 5.01 (1988) estabelece que: 
"A amostra deve cair sobre uma barra de aço rigidamente fixada perpendicularmente no alvo conforme especificado, de modo que sofra o máximo de dano. A altura da queda, do ponto de impacto na amostra até a superficie superior da barra, deve ser de $1 \mathrm{~m}$. A barra deve ser de aço doce, com $20 \mathrm{~cm}$ de comprimento e possuir uma seção circular com $15 \mathrm{~cm} \pm 0,5 \mathrm{~cm}$ de diametro. Deve-se utilizar uma barra mais comprida quando for possivel produzir um dano maior. A extremidade superior da barra deve ser plana e horizontal; e a sua aresta deve ser arredondada com um raio não superior a $6 \mathrm{~mm}$ ”.

\subsubsection{Ensaio de queda livre}

O protótipo do casco deve ser preparado para o ensaio de queda de uma altura de 9m de altura. A norma CNEN 5.01 (1988) estabelece:

"A amostra deve cair, em queda livre, de uma altura de 9m, sobre uma superficie plana e horizontal tal que, qualquer aumento da sua resistência ao deslocamento ou à deformação sob o impacto da amostra, não aumente significativamente o dano à amostra".

Na Figura 70 é apresentado o dispositivo para o teste de queda de $9 \mathrm{~m}$.

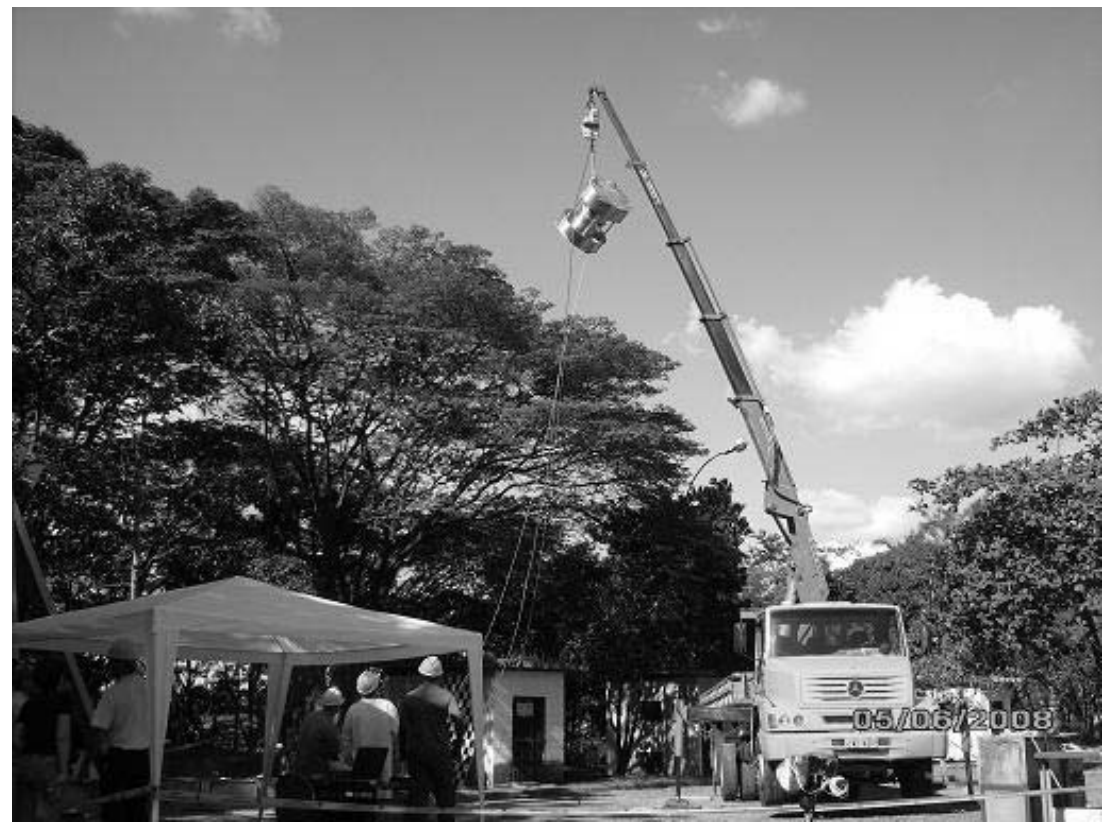

Figura 70 - Teste de queda de 9m de altura de protótipo de casco para CNQ (Local: Campo de testes CDTN/CNEN-MG)

Fonte: Romanato (2008); Foto: Romanato, L.S.

\subsubsection{Ensaio térmico}

O ensaio térmico deve ser realizado conforme a norma CNEN 5.01 (1988) que recomenda: 
“... a) envolver completamente a amostra a ser ensaiada, exceto para um sistema de suporte simples, num fogo resultante da combustão de um combustivel hidrocarbonado com ar, durante 30 minutos, em condição ambiental suficientemente calma para prover um coeficiente de emissividade média, no mínimo, igual a 0,$9 ;$ b) a temperatura média da chama deve ser de $800^{\circ} \mathrm{C}$ e a fonte de combustivel deve se estender, horizontalmente, além da superficie externa da amostra, no mínimo $1 \mathrm{~m}$, e, no máximo 3m; a amostra deve ser posicionada a $1 m$ de distância da superficie da fonte; c) pode-se empregar qualquer outro ensaio cujas características térmicas sejam equivalentes às citadas em a) e b); d) após cessar a aplicação do calor externo, a amostra deve resfriar naturalmente, e qualquer combustão de materiais da mesma deve prosseguir naturalmente; e) para fins de demonstração, o coeficiente de absorção superficial deve ser de 0,8, ou igual ao valor comprovado do embalado nas condições de exposição ao fogo acima citadas; o coeficiente de convecção deve ser igual àquele justificado pelo projetista caso o embalado fosse exposto ao fogo com as características citadas; f) com relação às condições iniciais do ensaio térmico, a demonstração da conformidade deve ser realizada considerando-se a hipótese de que o embalado estava a uma temperatura de equilíbrio ambiental de $38^{\circ} \mathrm{C}$; os efeitos da radiação solar podem ser desprezados antes e durante o ensaio, mas devem ser levados em consideração na subseqüente avaliação da resposta do embalado".

Se todos os ensaios atenderem ao estabelecido nas normas, e o protótipo for projetado e construído de acordo com um Programa de Garantia da Qualidade bem estabelecido, o casco poderá ser licenciado para transporte e armazenagem de combustível nuclear queimado.

\subsubsection{Análise de risco do casco}

Para análise de risco, deve ser desenvolvida uma extensa lista de eventos iniciais bem como avaliados os riscos associados a cada evento inicial. Os eventos iniciais considerados devem incluir:

- queda do casco dentro do edifício de contenção secundária durante as operações de transferência;

- eventos externos durante a armazenagem no local (como sismos, inundações, vendavais, impacto de raios, choques acidentais de aeronaves, ataques intencionais e explosões).

Devem ser modeladas falhas mecânicas e térmicas potenciais dos cascos, incluindo as térmicas causadas por danos durante o carregamento.

$\mathrm{Na}$ eventualidade de uma falha no casco, deve ser conhecido o inventário disponível do combustível queimado armazenado. 
$\mathrm{Na}$ análise, devem ser consideradas as condições meteorológicas e a distribuição da população nas proximidades do local de armazenagem.

De acordo com a metodologia do USNRC (2007), o risco para o público deve ser medido quanto à probabilidades de um acidente fatal imediato em um raio de 1,6km e uma fatalidade por câncer latente dentro de $16 \mathrm{~km}$ do local. Nenhuma fatalidade imediata deve ser esperada e o risco calculado resultante deve ser extremamente pequeno. Em estudo realizado pelo mesmo comitê de segurança, foi estimado que no primeiro ano de armazenagem de um casco, a freqüência de fatalidade de o trabalhador ter câncer é da ordem de $1,8 \times 10^{-12}$ por ano e nos anos subsequentes de armazenagem, a freqüência é da ordem de $3,2 \times 10^{-14}$ fatalidades por ano. (USNRC, 2007).

\subsubsection{Fabricação do casco}

A fabricação de um casco é um processo que envolve várias etapas tais como fundição, forja, corte por meio de serra ou arco de solda, laminação, usinagem, dobramento, soldagem, montagem e dos testes de aceitação.

No início da fase de fabricação os construtores devem possuir todos os desenhos do projeto com as configurações, dimensões, materiais e normas aplicáveis. São importantes, também, as especificações de fabricação, que devem identificar processos e materiais especiais a serem utilizados, e os requisitos de qualidade.

O planejamento das atividades a serem realizadas é essencial para que se atinja o sucesso das metas pré-estabelecidas. Por este motivo, a gerência das atividades é de suma importância. O plano de gerenciamento do projeto de construção deve estar pronto antes do início das atividades. A seleção dos fabricantes e fornecedores de insumos é muito importante em um projeto, pois a decisão afetará o custo, os prazos, a qualidade e a vida útil do casco.

O fabricante selecionado para confeccionar o casco deve desempenhar um trabalho contratado. Deverá ser verificada sua capacidade de gerenciar o projeto, escolher insumos, conduzir as fases de engenharia, manufatura e qualidade do produto final. Do ponto de vista da capacidade de manufatura, o fabricante deverá possuir maquinário apropriado como equipamento de soldagem, dispositivos de manuseio e elevação de materiais e instalações de inspeção e testes. A mão de obra empregada pelo fabricante e a experiência na realização de equipamentos similares, por exemplo, fabricantes de vasos de pressão, vasos de reatores ou de cestos para piscina de armazenagem de combustível. A mão de obra e a qualificação são muito importantes, visto que ainda nenhum casco de 
armazenagem de CNQ foi construído no Brasil. A fabricação deve atender às normas existentes no mundo, podendo ser citado como muito utilizada a norma ASME Boiler and Pressure Vessel Code (BPVC, Código de Vasos de Pressão e Caldeiras). Esse código abrange: a seleção de materiais; requisitos de projeto, de soldagem, e de fabricação; ensaios não destrutivos; inspeções; marcas; reparos e registros (ASME, 2007).

Na Figura 71 é apresentada uma proposta de seqüência esquematizada básica do processo de fabricação dos vários componentes do casco em um tempo que pode ser relativamente curto, um ano.

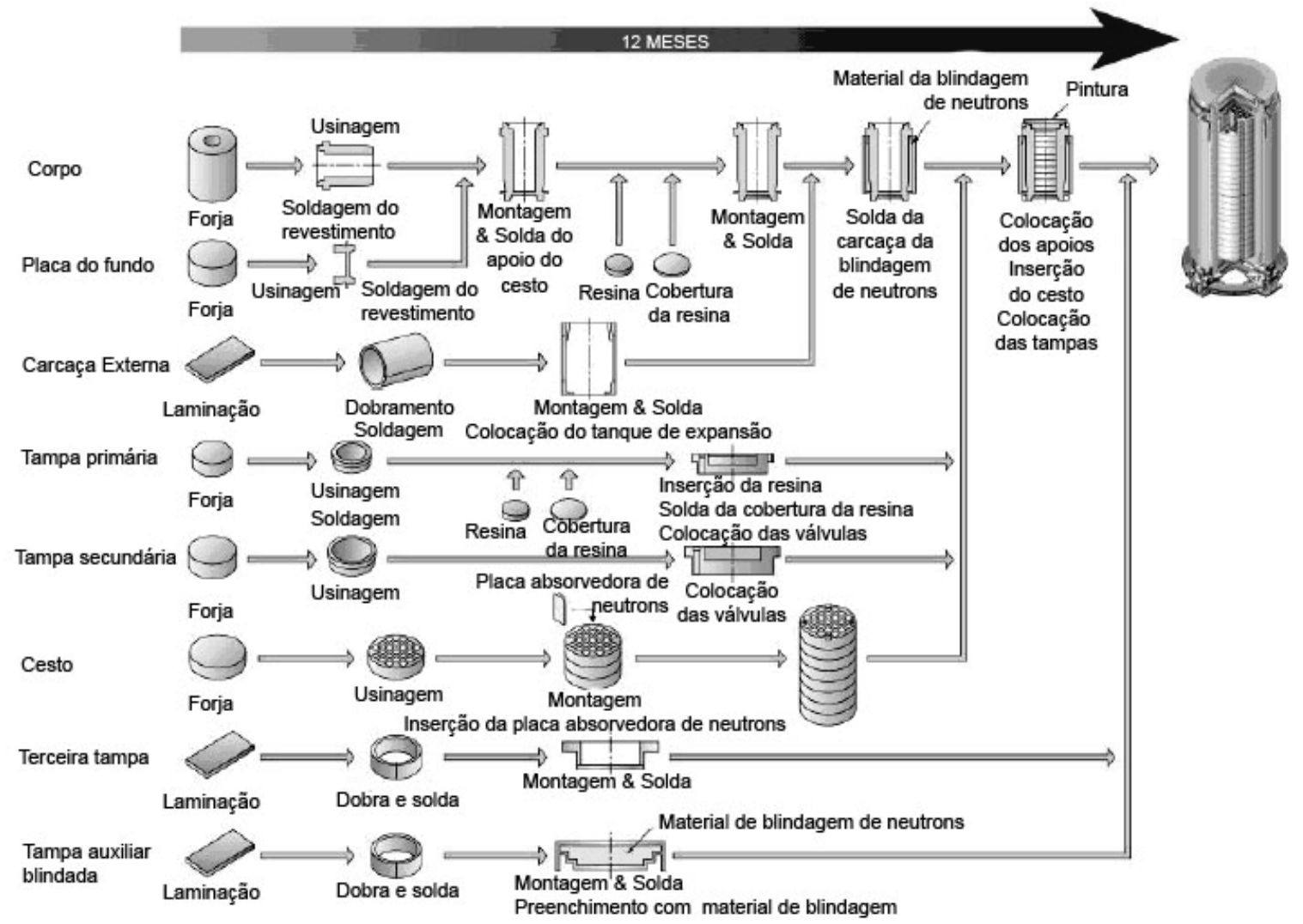

Figura 71 - Sugestão de esquema de fabricação de um casco metálico para CNQ ao longo de um ano

Fonte: Adaptado de Kawakami et al. (2004)

\subsubsection{Custo do casco}

Conforme Matveev et al. (2006) o custo por tonelada de urânio armazenado em um casco de aço com chumbo atingiria US\$81.000,00.

O casco proposto neste estudo permitirá transportar e armazenar 21 elementos com $832 \mathrm{~kg}$. Cada elemento tem uma massa de urânio de $543 \mathrm{~kg}$ (INB, 2009) e totaliza, para os 21 elementos, $11.403 \mathrm{~kg}$. Portanto, por essa estimativa, um casco para 21 elementos custaria perto de US\$925.000,00. 
Fairlie (2000) já havia informado os custos de alguns tipos de cascos, conforme apresentado a seguir (valores corrigidos para 2009):

- Casco VSC-24, de concreto, US\$367.500,00

- Casco NUHOMS-24P, de concreto, US\$466.000,00

- Casco TN-24, de aço, US\$1.103.500,00

- Casco TN-40, de aço, US\$ 857.400,00

No congresso 12th International Conference on Environmental Remediation and Radioactive Waste Management realizado em Liverpool, Grã Bretanha, no período de 11 a 15 de outubro de 2009, obteve-se informações importantes com os fabricantes de cascos. O casco NAC de aço e chumbo foi orçado na faixa de US\$750.000,00 e o casco CASTOR V-21, de ferro fundido, $€ \$ 2.000 .000,00$ (aproximadamente US\$ 3.000.000,00 com taxa de câmbio em 25/11/2009).

O custo estimado, portanto, para o casco proposto no presente trabalho está em torno de US\$930.000,00.

Para fins de comparação de custos, o preço do aço inoxidável 304 em chapa laminada, é de US\$5,35/kg, do urânio empobrecido $\left(\mathrm{U}_{3} \mathrm{O}_{8}\right)$ US $\$ 123,46 / \mathrm{kg}$ e do chumbo US\$1,16/kg. O preço do chumbo é do minério puro e do urânio já é o manufaturado pronto para uso na construção dos cascos (Metalprices, 2009).

\subsubsection{Liberação do casco para transporte e armazenagem}

Após o carregamento do CNQ no casco, secagem e fechamento, a liberação só é feita após os testes de contaminação da superfície externa e medição do nível de radiação superficial. Caso essa superfície esteja contaminada, deve ser descontaminada.

Diferentes técnicas de descontaminação podem ser aplicadas dependendo se a superfície é revestida com tinta especial ou não (Severa e Bar, 1991).

\subsection{Proposta de uma instalação nacional de armazenagem seca provisória de CNQ em cascos}

As cinco etapas mais relevantes da vida de uma instalação de armazenagem de CNQ são: a seleção do local, projeto, construção, operação e descomissionamento (Roshan et al., 2005). A aceitação por parte da população, aliada às características geofísicas da área é de fundamental importância na definição do local para construir uma instalação de armazenagem de CNQ. Após as escolhas dos locais candidatos a partir das áreas 
potenciais, são feitas consultas populares (audiências públicas), de forma que seja tomada a decisão, entre a população, da área na qual se construirá a instalação de armazenagem.

\subsubsection{Localização}

A localização das instalações nucleares de armazenagem seca de CNQ tem evoluído ao longo do tempo desde que a tecnologia nuclear foi introduzida pela primeira vez no mundo. No início essas instalações eram assentadas em áreas remotas afastadas das cidades e núcleos populacionais. Talvez, naquela época, esta conduta tenha sido relacionada com a origem militar da tecnologia nuclear, e em parte com o desejo de manter grandes instalações industriais longe dos centros populacionais.

Com o crescimento da demanda por energia e a retomada da construção de novas instalações de centrais nucleares é cada vez maior aliada à aceitação popular.

Existem regras internacionais para a localização de repositórios e de suas características mais específicas. Entre elas podem ser citadas a dos estágios de: planejamento e conceituação, busca por uma área mais conveniente; caracterização do local; e, confirmação. Cada uma das fases (estágios) possui um conjunto de especificações. McCombie (2005) publicou, com base na experiência européia, um guia sobre a localização de locais de armazenagem e repositórios que envolve aspectos técnicos e sócioeconômicas e que foi adaptado para efeito deste trabalho de tese para a localização de instalações de armazenagem seca para CNQ-PWR no Brasil, como pode ser visto na Tabela 23.

Tabela 23 - Tópicos para a localização de instalações nucleares.

\begin{tabular}{|l|}
\hline Parte técnica \\
\hline - As características geológicas devem ser propícias, devem ter propriedades geológicas, \\
geomecânicas, geoquímicas e hidrológicas adequadas para inibir o transporte de \\
radionuclídeos e permitir a construção segura da planta, sua operação e fechamento. \\
- O solo hospedeiro deve ser tal que não seja afetado pelas intempéries climáticas. \\
- O solo deve ter porosidade baixa para restringir o fluxo de água de modo a resultar em \\
baixo índice de difusão de radionuclídeos para o meio ambiente circunvizinho. \\
- As características da superfície e do subsolo devem permitir otimizar a infraestrutura. \\
- A localização geográfica da instalação de armazenagem deve ser tal que permita o \\
transporte seguro sem intercorrências que possam causar impacto ambiental
\end{tabular}


- As atividades humanas potenciais futuras devem ser consideradas e assegurar que a probabilidade que dessas atividades seja minimizada

- A escolha do local deve significar que a qualidade da instalação não será afetada ou que esses efeitos devam ser mitigados em um patamar aceitável

- O uso do solo deve estar de acordo com a planificação de futuro desenvolvimento da região circunvizinha.

- Os impactos sociais referentes a instalação no local escolhido devem ser aceitáveis com efeitos benéficos reforçados e efeitos negativos minimizados

Fonte: Adaptado de McCombie (2005)

Conforme Ryhänen (2000), a seleção das áreas para as instalações nucleares como local de acondicionamento de rejeitos radioativos e armazenagem temporária têm como fatores o planejamento, minimização da distância dos geradores de rejeitos e a infraestrutura. Outro fator importante é a aceitação pública que em muitos países, pode ou não, favorecer a demarcação dessas áreas para essa finalidade.

No Brasil, a Lei Federal 10.308, aprovada em 2001, estabelece que os depósitos intermediários sejam construídos, licenciados, administrados e operados segundo critérios, procedimentos e normas estabelecidos pela Comissão Nacional de Energia Nuclear.

A CNEN, por ser um órgão federal superior de planejamento, orientação, supervisão e fiscalização, estabeleceu normas e regulamentos de radioproteção e licenciamento, fiscalização e controle da atividade nuclear no Brasil.

A norma CNEN-NN-1.16 (2000) é exigida para as atividades que influenciem na qualidade de itens importantes à segurança, gerenciamento de uma instalação de armazenagem de CNQ em seus diversos estágios: escolha de local, projeto, construção, comissionamento, operação e descomissionamento. Esta norma estabelece a implantação de um sistema da qualidade para a instalação, bem como, fixa os critérios para a elaboração do Programa de Garantia da Qualidade em todos os estágios.

O CNQ brasileiro considerado no presente trabalho não pode ainda ser considerado rejeito. Mesmo assim a norma CNEN-NE-6.05 (1985) que deve ser considerada, pois estabelece critérios para a gerência de materiais radioativos em uma instalação radiativa, classificando-os de acordo com a atividade ou nível de radiação. Assim o CNQ é classificado como material radioativo de atividade alta. Essa norma trata 
da segregação, recipientes de acondicionamento, transporte, armazenagem temporária, tratamento, eliminação e transferência do CNQ quando considerado rejeito. Independente se o CNQ for considerado rejeito ou material radiativo de atividade alta e, temporariamente guardado, o local de armazenagem deve ser monitorado, estar distante de áreas de trabalho classificadas como livre (a proteção física do prédio deve permitir classificar o exterior do prédio como área livre), prover a proteção contra a ação de eventos naturais, possuir planos de proteção física, de radioproteção e de emergência, entre outros.

A Comissão Nacional de Energia Nuclear (1989), na norma CNEN-NE-6.06, considerou vários fatores para a escolha do local para construção de um depósito intermediário para rejeitos com níveis de radiação baixos e médios. Entre os critérios mínimos para esse depósito está, além da localização preferencialmente em terras públicas, identificar as regiões de interesse e potenciais e locais candidatos em várias escalas de detalhes. Cada local candidato deve ser claramente descrito quanto aos fatores ecológicos, sócio-econômicos, geológicos e fisiográficos e estudos detalhados devem ser feitos para cada um deles. $\mathrm{O}$ documento não contempla os rejeitos de atividade alta, portanto a escolha de um local para armazenagem temporária de CNQ no Brasil não está regulamentada, embora se possa utilizar o documento como orientação para fazer a escolha.

A IAEA $(1994,2006)$ indica que o projeto e construção de uma instalação devem proporcionar medidas para limitar possíveis impactos radiológicos nos indivíduos, população e meio-ambiente, incluindo aqueles advindos de descargas e liberações descontroladas. Deve ser previsto, também na fase de projeto, um plano conceitual para seu descomissionamento.

De todas as informações descritas anteriormente, a opção sugerida quanto à escolha para a armazenagem temporária no Brasil foi para cascos de duplo propósito.

Os motivos para essa escolha foram os seguintes:

a) Colocação dos elementos combustíveis queimados dentro do casco, que após o fechamento, não será mais aberto. Esse casco poderá permanecer em algum local determinado do prédio do reator (local no qual se encontra a piscina de resfriamento) e poderá ser movimentado de acordo com os planos internos de distribuição dos cascos; e,

b) Em caso se mudança de local do combustível queimado, o casco poderá ser transportado para outro local sem que seja necessário transferir os elementos combustíveis para um outro invólucro de transporte. No local 
escolhido poderá novamente permanecer armazenado ou seguir para outro destino escolhido.

A tendência atual mundial para armazenagem temporária de CNQ é a construção de instalações centralizadas, de grande porte, de modo que todo o combustível gerado no país seria administrado nesse local. Verifica-se, no entanto, que essa tendência é adotada por países que têm pequena extensão territorial. No entanto, países como os Estados Unidos e Alemanha, estão construindo instalações regionalizadas.

Os motivos principais para a instalação de armazenagem no local do reator são:

a) Quem gera o CNQ terá condições mais seguras para gerenciar a armazenagem, se possuir uma área disponível próxima ao reator; e,

b) Nas condições atuais, o transporte seguro do CNQ para fora da instituição do reator pode ser temeroso, pois o Brasil não dispõe de rede ferroviária apropriada ou malha rodoviária com pavimento que suporte a carga.

\subsubsection{Proposta de instalação de armazenagem seca de CNQ no Brasil}

Antes da construção de qualquer instalação nuclear devem ser considerados os impactos provenientes da natureza causados por vendavais, chuva, nevasca, congelamentos, raios, deslizamentos de terra, terremotos, salinidade do ar, animais, enchentes, furacões e impactos causados pelo homem, tais como, incêndios externos à instalação, ondas de choque originárias de explosões químicas, incidentes com mísseis, queda de aviões e ataques terroristas. Esses eventos devem ser identificados antes da fase de seleção de local, construção e licenciamento da instalação e previstos nos Estudos de Impactos Ambientais e Relatórios de Análise de Segurança.

As dimensões dos cascos são 'dados de entrada' para o dimensionamento de uma instalação de armazenagem seca de CNQ. Nesse intuito, foi feita uma simulação para o sítio onde se encontram os reatores de Angra.

- O reator de Angra 1 possui 121 elementos combustíveis e Angra 2, 193 elementos combustíveis, para geração de energia. A cada ano, é trocado perto de $1 / 3$ do combustível da capacidade total do reator, e o resultado é: em Angra 1, 41 elementos CNQ por ano e em Angra 2, 64 elementos CNQ por ano. Portanto, o CNQ gerado anualmente poderá ser acomodado em 2 cascos de 21 elementos, para Angra 1 e em 3 cascos de 21 elementos, para Angra 2.

- Se for considerada uma vida útil do reator de 30 anos, Angra 1 acumulará 1230 elementos CNQ distribuídos em 59 cascos e Angra 2, 1930 elementos CNQ 
distribuídos em 91 cascos. A esse total podem ser somados cascos para prováveis elementos danificados e, talvez, para um aumento de vida útil da instalação.

- Se houver um aumento em 10 anos na vida útil da instalação, ter-se-á, ainda, mais 20 cascos para Angra 1 e 30 para Angra 2. A instalação de armazenagem seca de CNQ deveria ser dimensionada para 79 cascos de CNQ de Angra 1 e 121 para Angra 2. Assim sendo, essa instalação deveria ter uma capacidade inicial, para acomodar 200 cascos de CNQ.

Após a construção e operação de Angra 3, visto que essa unidade é semelhante à Angra 2, ter-se-á mais 1930 elementos CNQ em 30 anos, distribuídos em 91 cascos. Analogamente à Angra 2, com aumento da vida útil em 10 anos, devem ser somados mais 30 cascos, chegando a um total de 121 cascos.

Desse modo, uma instalação que atenda Angra 1, 2 e 3 deverá ter capacidade para armazenar 321 cascos de CNQ.

As dimensões principais da instalação coberta para armazenagem do combustível queimado para as usinas de potência PWR é apresentada na Figura 72. Como pode ser visto nessa figura, o comprimento frontal é de aproximadamente 132,5m e a profundidade total, $72,5 \mathrm{~m}$. A altura total externa do prédio deverá ser de $11,2 \mathrm{~m}$, e altura interna de 9,6m. O piso deverá ter uma espessura de no mínimo $1 \mathrm{~m}$, de concreto armado, para suportar a massa dos cascos.

O projeto conceitual da instalação de armazenagem seca de CNQ está apresentado nos APÊNDICES J a N. Considerou-se uma construção em forma modular e o primeiro módulo (APÊNDICES J a M) possuiria a capacidade para armazenar 130 cascos. O segundo módulo, contíguo ao primeiro, em versão simétrica, também teria capacidade para 130 cascos, totalizando 260 cascos. O terceiro e último módulo teria capacidade para 80 cascos e seria construído na parte posterior da instalação. A capacidade total seria para 340 cascos (APÊNDICE N). Desta forma, existe uma margem de segurança para a armazenagem, caso as usinas tenham sua vida útil aumentada ao menos em 10 anos. 


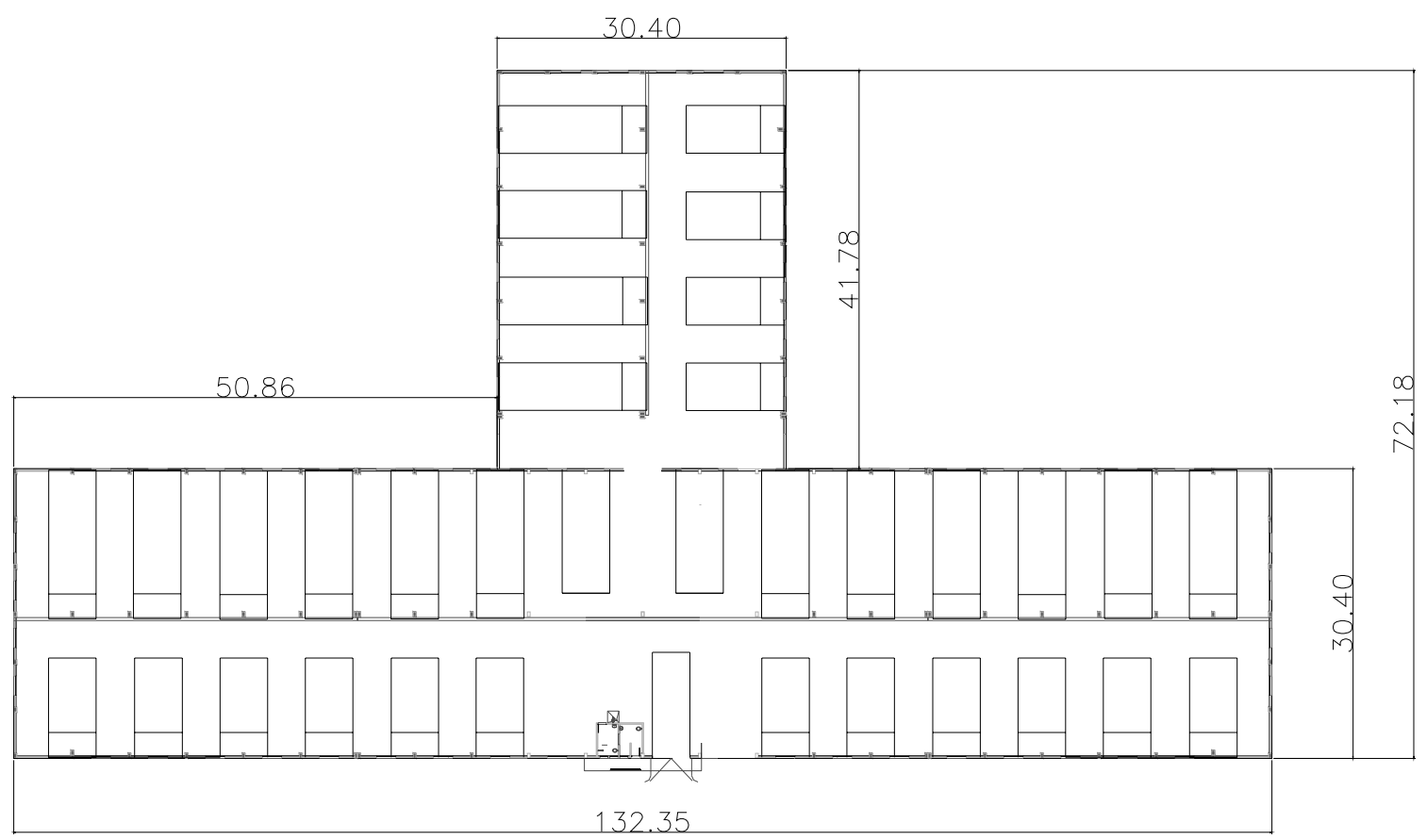

Dimensões em metros

Figura 72 - Proposta de planta da instalação de armazenagem de CNQ-PWR e dimensões principais (Vide ANEXO M)

Propõe-se que os cascos sejam instalados em recinto fechado, apenas para evitar intempéries e corrosão, visto que as usinas nucleares de Angra estão localizadas em região à beira mar e não precisam de blindagem adicional. Contra a corrosão é indicada uma pintura na superfície externa com material adequado que resista ao calor e radiação.

A instalação deverá comportar uma ponte rolante (com capacidade para 100ton) de pequena extensão, apenas para o descarregamento dos cascos com CNQ vindos dos reatores. A movimentação dos cascos dentro da instalação será realizada por veículos de movimentação de carga, especialmente projetados para esta finalidade, para oferecer maior mobilidade que as pontes rolantes.

Na Figura 73 é mostrado um veículo para movimentação de cascos, um modelo diferente do que se observa na Figura 50. 


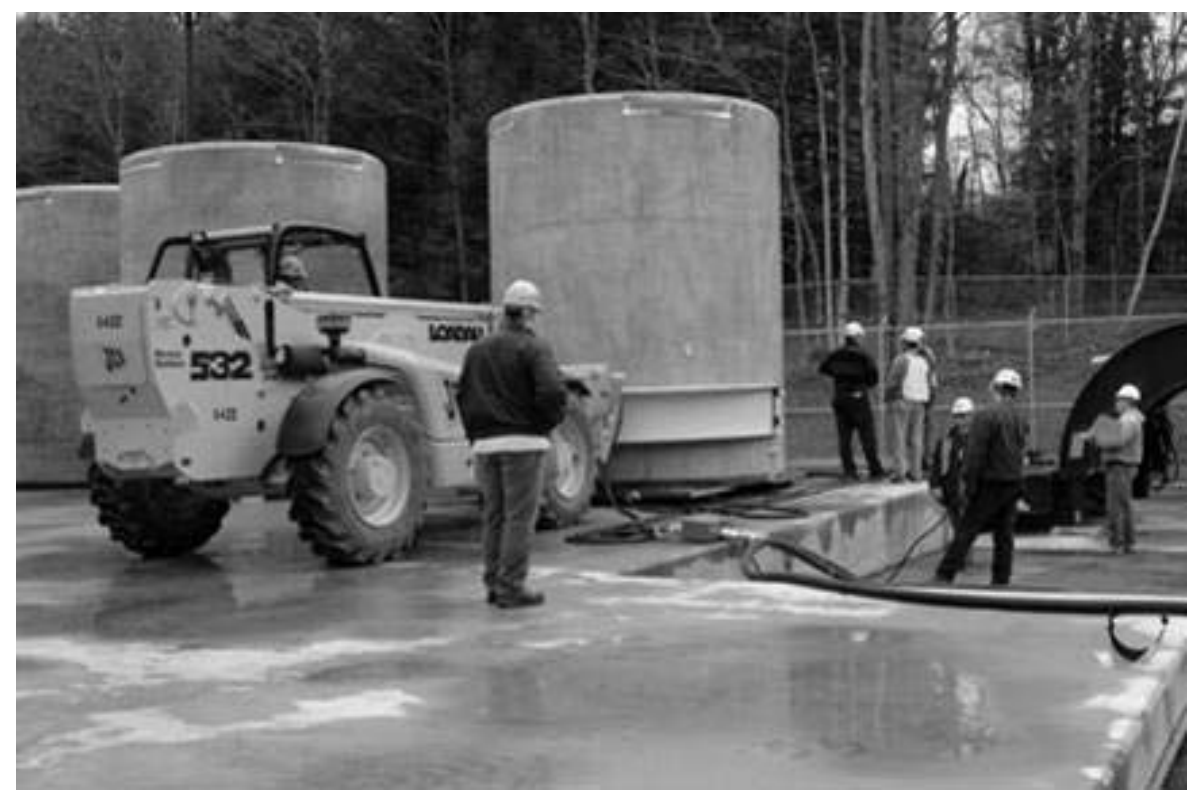

Figura 73 - Exemplo de veículo para a movimentação de cascos com CNQ nas instalações de armazenagem.

Fonte: Yankee Rowe (2009)

A Figura 74 mostra o desenho esquemático de veículo que se sugere para movimentação de cascos na instalação proposta no presente trabalho. O veículo para movimentação deverá ser capaz de elevar e transportar $90.000 \mathrm{~kg}$ e deverá possuir o menor peso possível. O estudo do veículo transportador deverá ser objeto de estudo no futuro. $\mathrm{O}$ Peso Bruto Total (PBT) não deverá ultrapassar 140.000kg, senão o piso deverá ser muito mais reforçado, onerando o custo total da instalação.

Esse veículo movimentador de carga poderá também, com pequenas alterações, realizar o transporte desde os reatores até a instalação de armazenagem, dispensando o uso de um caminhão ou outro veículo de transporte especial e eliminando a pequena ponte rolante prevista. 

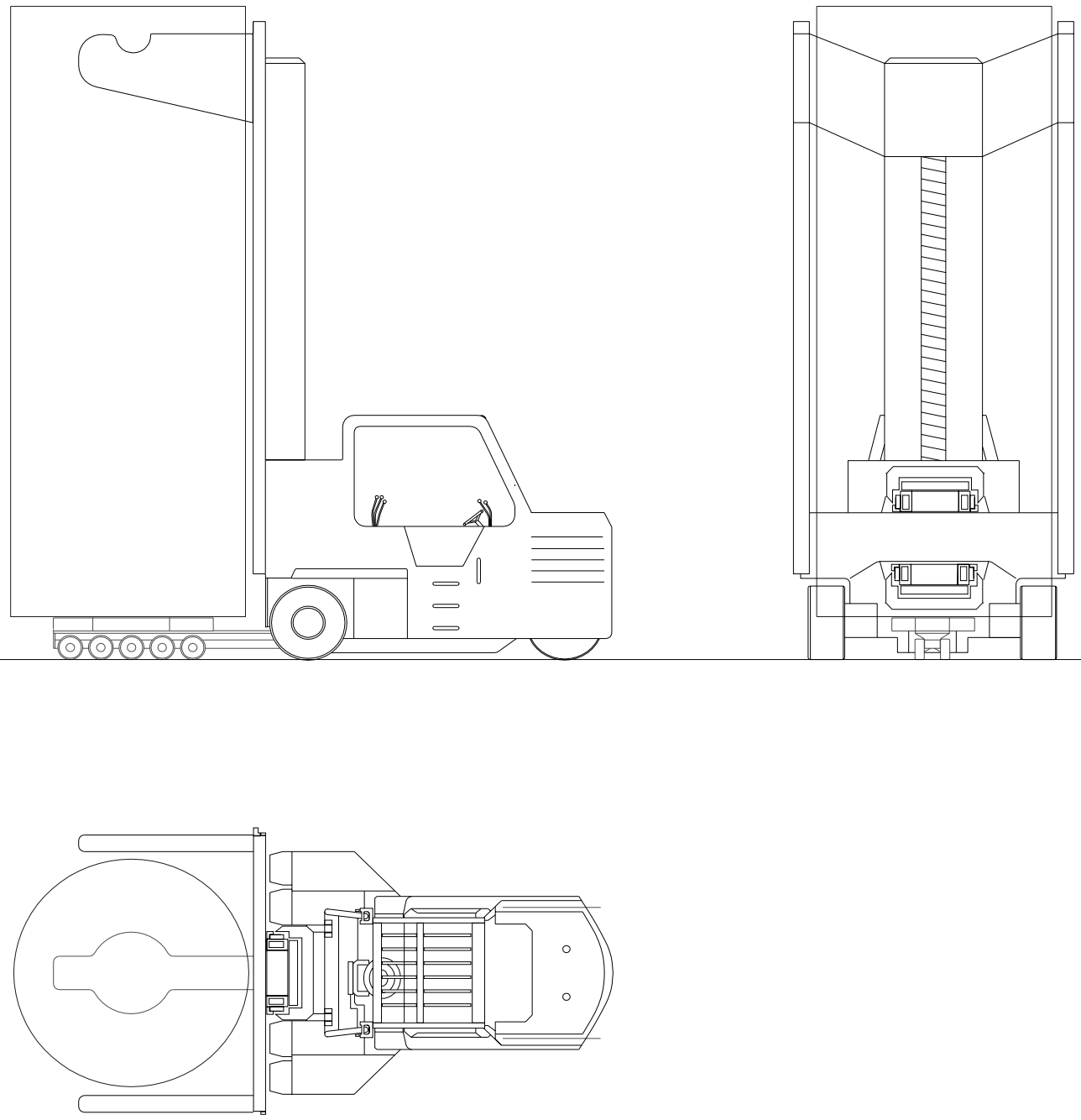

Figura 74 - Desenho esquemático de proposta de veículo para a movimentação de cascos, com CNQ-PWR dentro da instalação de armazenagem seca.

Na Figura 75 é mostrada a localização da instalação de armazenagem de CNQPWR no terreno das Usinas Angra 1 e 2, considerando a inclusão do reator Angra 3. O local é ilustrativo e deverá passar por estudos para se concluir onde será a melhor localização. 


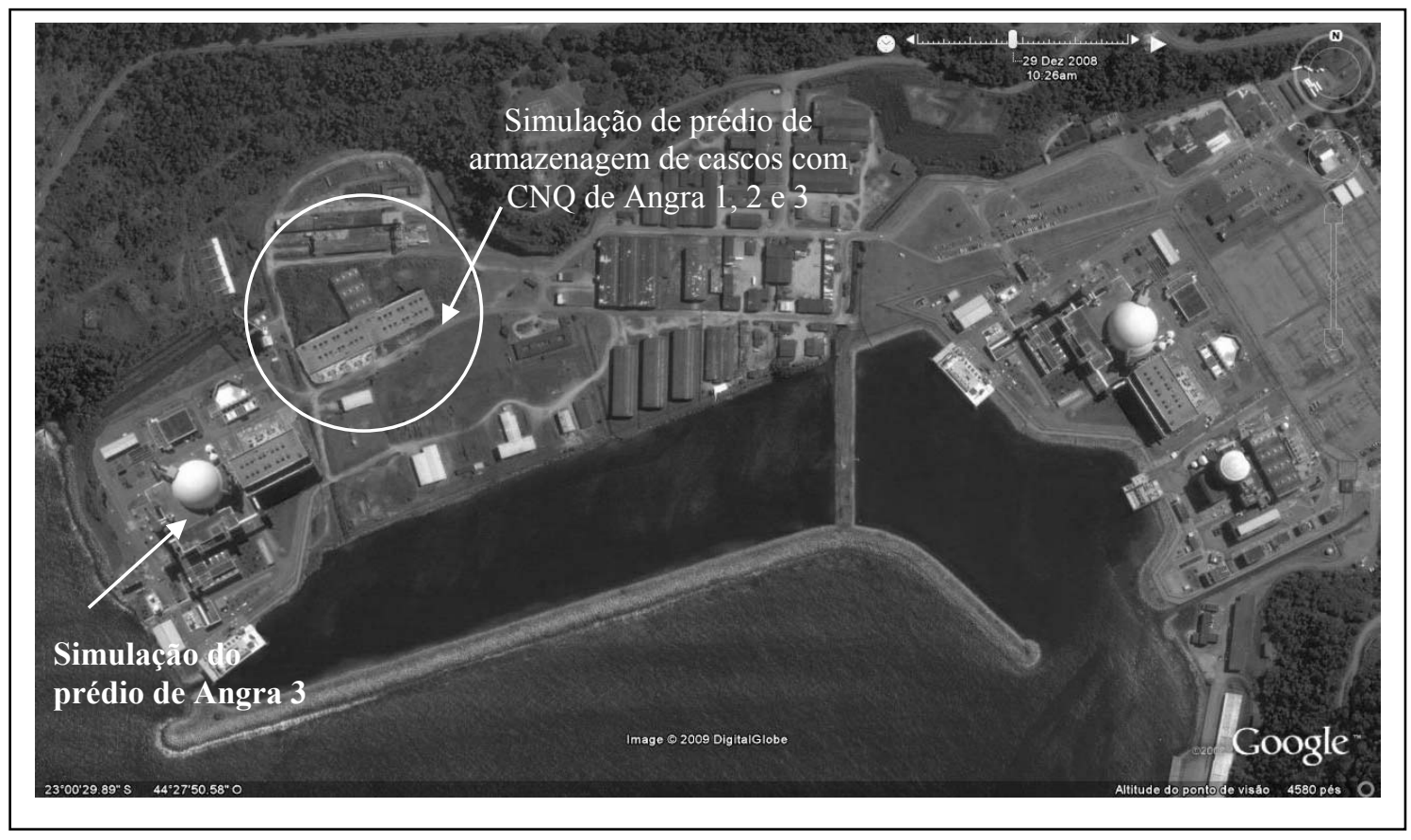

Figura 75 - Vista aérea de uma simulação de instalação de armazenagem de CNQ-PWR de Angra 1, 2 e simulação de Angra 3 localizado no próprio terreno da central Nuclear de Angra.

Fonte: Adaptado de Google Earth (2009)

\subsubsection{Processos de licenciamento de uma instalação de armazenagem seca de CNQ no Brasil}

Os processos de licenciamento devem englobar o estudo da exeqüibilidade da localização, os projetos de concepção, preliminar e de detalhamento, a construção, o comissionamento da instalação e as fases de operação e de descomissionamento

\subsubsection{Processo de licenciamento ambiental}

Antes do processo de licenciamento da instalação, o projeto deve ser licenciado quanto ao meio ambiente. O licenciamento ambiental é uma obrigação legal (Lei $n^{\circ} 6.938$, de 31/08/1981), prévia à instalação de qualquer empreendimento ou atividade potencialmente poluidora ou degradadora do meio ambiente e possui como uma de suas mais expressivas características a participação social na tomada de decisão, por meio da realização de Audiências Públicas como parte do processo (IBAMA, 2009).

O processo de licenciamento ambiental possui três etapas distintas: Licenciamento Prévio, Licenciamento de Instalação e Licenciamento de Operação. 
- Licença Prévia (LP) - Deve ser solicitada ao IBAMA na fase de planejamento e antes da construção, alteração ou ampliação da instalação. Essa licença não autoriza a instalação do projeto, e sim aprova a viabilidade ambiental do projeto e autoriza sua localização e concepção tecnológica. Além disso, estabelece as condições a serem consideradas no desenvolvimento do projeto executivo.

- Licença de Instalação (LI) - Autoriza o início da obra da instalação. O prazo de validade dessa licença é estabelecido pelo cronograma de instalação do projeto ou atividade, não podendo ser superior a seis anos.

- Licença de Operação (LO) - Deve ser solicitada antes da instalação entrar em operação, pois essa licença autoriza o início do funcionamento do empreendimento. Sua concessão está condicionada à vistoria a fim de verificar se todas as exigências e detalhes técnicos descritos no projeto aprovado foram desenvolvidos e atendidos ao longo de sua construção e se estão de acordo com o previsto nas LP e LI. O prazo de validade é estabelecido, não podendo ser inferior a quatro anos e superior a dez anos.

Para subsidiar a etapa do LP, deve ser encaminhado ao IBAMA o Estudo de Impacto Ambiental / Relatório de Impacto no Meio Ambiente (EIA/RIMA). O EIA é um documento técnico-científico compostos por Diagnóstico ambiental dos meios físico, biótico e socioeconômico, Análise dos impactos ambientais do projeto e de suas alternativas, Definição das medidas mitigadoras dos impactos negativos e elaboração de medidas mitigadoras dos impactos negativos e, Programas de Acompanhamento e Monitoramento. O RIMA é o documento público que reflete as informações e conclusões do EIA e é apresentado de forma objetiva e adequada a compreensão de toda a população. Nessa etapa são realizadas Audiências Públicas para que a comunidade interessada ou afetada pela instalação seja consultada.

\subsubsection{Processo de licenciamento nuclear}

Paralelamente, deve ser iniciado o processo de licenciamento nuclear, conforme a Norma CNEN NE-1.04 (2002) com os estudos envolvendo todas as etapas do ciclo da instalação. A primeira ação quanto ao licenciamento nuclear é a Aprovação do Local, que se refere à área em que a instalação será construída. Na sequência deverá ser 
obtida a Licença de Construção, após a aprovação dos conceitos de segurança adotados no projeto. Após a conclusão da construção, deverá ser emitida a Autorização para Utilização de Material Nuclear, que permitirá a colocação de cascos carregados, já licenciados, e o comissionamento definitivo.

Passadas todas as etapas anteriores, deverá ser emitida a Autorização para Operação Inicial, durante a qual será verificado o desempenho da instalação sob condições reais, e, caso este seja satisfatório, será emitida a Autorização para Operação Permanente.

Para a emissão dessas licenças e autorizações, é necessário que o requerente apresente os documentos relacionados a seguir.

\subsection{Aprovação do Local}

É necessário o Requerimento de aprovação do local acompanhado do Relatório do Local, no qual é informado:

- Emprego da instalação, sua capacidade nominal, materiais radioativos que estarão contidos na mesma e conseqüências de uma liberação acidental do material armazenado. Ainda, quais as características de segurança e qual o sistema de contenção previsto para evitar a liberação do material radioativo.

- Distribuição da população, vias de acesso, características das cercanias e distâncias aos centros populosos.

- Características físicas do local, incluindo sismologia, meteorologia, geologia e hidrologia.

- Análise preliminar da influência da construção no meio ambiente vizinho, durante sua operação normal e em caso de acidentes.

- Programa preliminar de monitoração ambiental.

\subsection{Licença de Construção}

A construção da instalação no local aprovado só pode ser iniciada após a concessão da Licença de Construção, cujo requerimento deve incluir informações sobre o cronograma preliminar da obra e os prazos estimados para o término da construção, além dos documentos seguintes:

- RPAS - Relatório Preliminar de Análise de Segurança, que deve conter as qualificações técnicas do requerente; descrição da análise de segurança do local; descrição e análise da instalação; projeto preliminar da instalação; análise 
preliminar e avaliação do projeto e desempenho de itens da instalação; descrição das variáveis assumidas em decorrência da segurança; planos preliminares de treinamento de pessoal e de operadores; programa de garantia da qualidade (PGQ) para a fase de projeto e construção; programas que necessitam de pesquisa e desenvolvimento; identificação dos riscos potenciais para funcionamento; planos preliminares de emergência; descrição do sistema de liberação de efluentes e armazenagem de rejeitos radioativos; plano preliminar de proteção contra incêndio.

- PPPF - Plano Preliminar de Proteção Física

\subsection{Autorização para manipulação de Material Nuclear}

Essa autorização será concedida após a comprovação de que a instalação está pronta para receber o material nuclear.

\subsection{Autorização para Operação Inicial}

O requerimento para essa autorização deve incluir o cronograma para essa atividade, acompanhada dos documentos seguintes:

- RFAS - Relatório Final de Análise de Segurança, que deve conter descrição da instalação; resultados de programas de monitoração ambiental e meteorológica desenvolvidos; descrição e análise dos itens da instalação; análise final e avaliação do projeto como construído; informações referentes à operação; planos preliminares de treinamento de pessoal e de operadores; programa de garantia da qualidade (PGQ); especificações técnicas propostas, descrição do plano de emergência; plano de proteção contra incêndio.

- PFPF - Plano Final de Proteção Física

\subsection{Autorização para Operação Permanente}

O requerimento para essa autorização deve ser acompanhado dos documentos seguintes:

- Prazo de operação desejado;

- Dados complementares que não tenham sido incluídos no RFAS;

- Relatório com descrição do desenvolvimento das atividades na fase de AOI;

- Relatório de testes da fase de AOI;

- PGQ para a fase de operação conforme norma CNEN NN 1.16 (CNEN, 2000); e, 
- Demonstração de que a construção esteja completamente terminada.

Khan e King (2003) relataram que, no Canadá, o tempo do licenciamento de uma instalação de armazenagem, nos moldes exigidos pela CNEN, até o início da operação foi de sete anos.

\subsubsection{Custo de uma instalação de armazenagem seca}

Os custos de uma instalação de armazenagem seca temporária podem ser divididos em custos de desenvolvimento, investimentos, operacionais, de renovação, de descomissionamento e de transporte.

Os custos de desenvolvimento são aqueles provenientes dos estudos iniciais da construção de uma instalação de armazenagem. Incluem estudos iniciais de viabilidade, projeto conceitual e outros necessários para análise e avaliação da instalação antes do início da construção.

Os custos de investimentos envolvem todas as despesas decorrentes da construção da instalação. No investimento estão incluídos: a compra e preparação do terreno, projeto de engenharia, infra-estrutura, construção, mão-de-obra direta, aquisição de equipamentos do processo, serviços, comissionamento, licenciamento, segurança e outras despesas que ocorram durante a construção.

Os custos operacionais compõem-se de todas as despesas associadas com a instalação. Esses custos, normalmente, são especificados em base anual e incluem mão-deobra direta e indireta, bens e materiais, manutenção, apoios (proteção física, monitoração ambiental), seguros, taxas, etc.

Os custos de renovação são aqueles decorrentes da situação quando equipamentos grandes ou parte da instalação se tornam obsoletos e é necessário trocá-los por outros mais modernos, fazer a renovação das licenças e melhorar os sistemas. Normalmente, esses custos surgem se a instalação começa a se tornar um local para a armazenagem em longo prazo. Podem ser citados como exemplos: a melhoria da instrumentação e a substituição do sistema de proteção física.

Os custos do descomissionamento são aqueles relacionados com a atividade de fechamento definitivo da instalação, da descontaminação, restauração do sítio e conseqüente retirada do combustível nuclear queimado do local e possível gerencia dos rejeitos radioativos operacionais gerados. 
Finalmente, os custos de transporte abrangem um investimento específico e são resultantes dos custos operacionais e de renovação.

$\mathrm{Na}$ Europa, o custo de construção e operação de uma instalação de armazenagem seca, em 1978, variava entre US\$ 300,00 e 488,00 por quilograma de urânio (Held e Hintermayer, 1978). Em 1994, a IAEA estimou os custos de construção, armazenagem e operação de uma instalação de armazenagem seca, localizada próximo ao reator, para 20 anos de operação, em US\$370,00 por quilograma de urânio (valores corrigidos para 2008) (IAEA, 1994).

Se a instalação de armazenagem for construída no próprio sítio do reator nuclear, os custos de transporte serão muito reduzidos.

O custo de construção tende a diminuir com o passar do tempo, em razão da evolução tecnológica e do crescente aumento do número de empresas especializadas em construção dessas instalações.

Nos EUA, os custos estimados para a construção de uma instalação seca para armazenagem do CNQ em cascos, independente dos tipos de cascos, variam de US\$8 milhões a US\$12 milhões para 5.000ton CNQ (Bunn et al., 2001).

O valor da construção da instalação completa, proposta no presente estudo para 340 cascos com 21 elementos CNQ-PWR na Central Nuclear Almirante Álvaro Alberto em Angra dos Reis, sem considerar os custos dos cascos, da operação da instalação e o licenciamento, pode ser estimado hoje em dia em cerca de US\$15 milhões, baseando-se na proposição de Bunn et al., com valores corrigidos.

\subsection{Transporte de cascos com CNQ}

Para o transporte de CNQ-PWR no Brasil são necessárias algumas exigências específicas que são encontradas na Norma CNEN-NE 5.02.

Quanto aos requisitos gerais a norma estabelece:

"4.1.1 Para o transporte seguro do elemento combustivel devem ser usados recipientes que atendam aos requisitos aplicáveis estabelecidos pela CNEN.

4.1.2 Na especificação de equipamentos para transporte de recipientes carregados devem ser considerados os seguintes requisitos:

a) compatibilidade com as características do recipiente carregado ;

b) proteção do recipiente carregado contra danos causados por possíveis acidentes durante o transporte; 
c) alta confiabilidade operacional.

4.1.3 Deve ser apresentada à CNEN documentação com descrição dos seguintes tópicos:

a) características de projeto dos recipientes;

b) análise dos acidentes previsiveis com os recipientes carregados, e das medidas adotadas para preveni-los ou minorar as suas conseqüencias;

c) características dos equipamentos de transporte e proteção dos recipientes carregados demonstrando serem os mesmos confiáveis e estruturalmente adequados para suportar os esforços impostos;

d) modo de fixação dos recipientes carregados nos veículos de transporte"

Quanto aos requisitos pré-operacionais:

"4.2.1 Antes do carregamento em cada recipiente, deve ser feita uma inspeção com o objetivo de verificar:

a) se o recipiente se encontra limpo e em condições de uso;

b) a identificação dos elementos combustiveis e respectivos recipientes, bem como a documentação pertinente.

4.2.2 No caso de elementos combustiveis não irradiados, deve ser observado o seguinte:

a) inspecioná-los quanto à limpeza antes de serem colocados nos recipientes;

b) proteger os que não forem imediatamente transportados de modo a manterem as condições de limpeza até a ocasião de embarque;

c) empregar somente métodos de limpeza aprovados.

4.2.3 Após a colocação do elemento combustivel dentro do recipiente, este deve ser visualmente inspecionado quanto ao acondicionamento, documentação e qualquer reparo feito após a inspeção.

4.2.4 Se todos os requisitos pré-operacionais estiverem satisfeitos, o recipiente deve ser lacrado, verificando-se se os rótulos estão devidamente preenchidos com os valores dos indices de transporte pertinentes."

No item referente aos requisitos operacionais lê-se:

“4.3.1 Os recipientes carregados devem ser colocados ou retirados do veículo transportador, um de cada vez.

4.3.2 O peso, centro de gravidade e pontos de içamento dos recipientes carregados devem ser respeitados, para que seja assegurado um manuseio apropriado. 
4.3.3 As temperaturas superficiais e as pressões internas dos recipientes carregados devem ser verificadas onde aplicável, em conformidade com os procedimentos de manuseio e transporte."

E quanto aos aspectos administrativos:

"4.4.1 Devem ser estabelecidas, em procedimentos escritos, medidas adequadas para carregamento e descarregamento dos recipientes, a fim de:

a) evitar uma condição de criticalidade acidental; $e$

b) assegurar que somente sejam carregados elementos combustiveis irradiados, cujos históricos de irradiação e tempo de resfriamento sejam tais que o inventário dos produtos de fissão e calor residual de decaimento estejam dentro dos limites especificados para o tipo de recipiente utilizado.

4.4.2 Devem ser estabelecidos procedimentos para teste e manutenção dos equipamentos de içamento, de modo a aumentar sua confiabilidade $e$ reduzir a probabilidade de queda acidental.

4.4.3 O transporte dos elementos combustiveis deve ser previamente autorizado pela CNEN."

No presente trabalho, o transporte do CNQ já acondicionado em cascos das usinas nucleares de Angra 1, 2 e 3 a partir de cada reator até a instalação de armazenagem será feito por veículo motorizado (Figura 74).

Em princípio, esse veículo deve ficar apenas dentro da instalação de armazenagem. Porém, dependendo da distância percorrida e para reduzir gastos com novo veículo de transporte, este veículo teria de ser projetado de modo a assegurar a retirada e entrega dos cascos sem ofrer nenhum dano no deslocamento entre edifícios. O leito carroçável deve ser reforçado.

Neste aspecto as normas da CNEN-NE 5.02 acima citadas deverão, oportunamente, ser aperfeiçoadas para o CNQ acondicionado em cascos multi-propósito, especificamente para o veículo que deve passar por testes preliminares que envolvam: velocidade de deslocamento, estabilidade vertical e horizontal em linha reta e em curvas; fadiga da carroceria em situações extremas como calor, ambiente salino, intempéries; e, resistência ao peso vertical e horizontal, entre outras. Outro item importante a ser determinado é a taxa de exposição na superfície externa do veículo, na posição do motorista e a um metro do mesmo. A operação de deslocamento deve ser acompanhada por pessoal especializado. 
5 DISCUSSÃO 


\section{DISCUSSÃO}

Desde a década de 50, a demanda por energia elétrica tem crescido de modo intenso. As fontes alternativas de geração de energia conhecidas não permitiram sustentar essa demanda e a construção de reatores de potência para geração de energia elétrica ao redor do mundo foi uma das soluções encontradas para este fim. Hoje em dia existem, em operação no mundo, 441 reatores comerciais (265 - PWR; 94 - BWR; 44 - PHWR; 18 AGR e Magnox; 12 - RBMK; 4 - FBR; 4 - outros) e mais 287 reatores de pesquisa. Ao longo das últimas décadas este crescimento teve como resultado a geração de combustível nuclear queimado, retirado do núcleo dos reatores para ser trocado por um combustível novo que permite dar continuidade ao seu funcionamento (WNA, 2009).

Em alguns países como na França, Rússia e Japão, o CNQ é reprocessado para o próprio país, ou para terceiros, e a economia chega a ser ao redor de $25 \%$ no processo completo do ciclo do combustível nuclear porque reduz, em parte, a prospecção ou a compra de urânio. Porém, nos países em que o reprocessamento não é feito, o CNQ permanece por um tempo, geralmente longo, em piscinas, na própria instalação do reator, aguardando sua retirada para armazenagem fora da instalação como rejeito radioativo, incluindo deposição em repositórios qualificados, quando estes forem construídos e licenciados.

Durante a vida útil do reator, perto de um terço do combustível é anualmente trocado por combustível novo. O acúmulo de combustível queimado nas piscinas para resfriamento começou a tornar-se problemático e, a partir da década de 70, novos sítios de armazenagem começaram a ser estudados e construídos. Surgiram, assim, diferentes concepções desses novos tipos de instalações que basicamente podem ser úmidas ou secas. As mais comuns ainda são as úmidas, localizadas no próprio reator, mediante o aumento da capacidade das piscinas, e as secas que, ou são construídas no mesmo terreno que o reator ou em locais afastados da central nuclear. Ambas as tecnologias de armazenagem são hoje tecnicamente bem conhecidas e dominadas. A corrosão dos elementos combustíveis na água das piscinas de resfriamento não é mais um problema, porque começaram a ser produzidos combustíveis a base de alumínio e este, em condições controladas, apresenta corrosão localizada apenas 30 anos após a submersão. A armazenagem seca, no entanto, é reconhecidamente mais vantajosa porque elimina a necessidade de tratamento da água, problemas com corrosão de elementos antigos, acidentes por vazamento de água da 
piscina, e não requer monitoramento e manutenção tão intensos como a úmida. (Ritchie, 1998)

A gestão do CNQ na fase da armazenagem deve abordar requisitos como: processo de retirada do núcleo do reator; transferência para os invólucros de armazenagem; criticalidade; transporte; forma de armazenagem; radioatividade envolvida; calor de decaimento e a forma de sua remoção; proteção aos indivíduos; proteção do meio ambiente; segurança física e radiológica durante o transporte e armazenagem; proteção contra ataques terroristas; e, a gerência que leva em consideração todos os itens citados aliados aos custos e licenciamentos periódicos (Glasstone e Sesonske, 1975; Duderstadt e Hamilton, 1976; Cochran e Tsoulfanidis, 1992; IAEA, 2006).

Os conceitos de projeto de cascos de armazenagem de CNQ, hoje em dia, são bem diferentes dos conceitos considerados há décadas atrás, quando o transporte de combustível nuclear só ocorria para as instalações de reprocessamento ou seria feito em depósitos intermediários ou repositórios definitivos. Agora, o projeto de construção do casco e do local de armazenagem leva em conta diversos aspectos novos que são questionados, como: Que tipo de casco deve ser confeccionado para o tipo de combustível atualmente usado? Pode-se apenas copiar modelos de outros países? Vale a pena considerar insumos mais modernos como urânio exaurido ou cermets para a confecção do casco, mesmo que seu custo seja bastante elevado? Esses materiais modernos vão responder da mesma maneira como os que no presente são amplamente conhecidos como o aço e o cimento? Como encontrar o local mais apropriado para armazenagem desses cascos num determinado país? Que tipo de exigências envolve a construção e manutenção dos locais de armazenagem de cascos autóctones para CNQ? Que sistemas de transporte serão usados? Como será feito o deslocamento dos cascos com CNQ dentro das instalações de armazenagem? Muitos países têm trabalhado individualmente e em conjunto para responder a esses questionamentos (Haire et al., 2004).

De acordo com toda a literatura analisada referente ao combustível de reatores comerciais de potência do tipo PWR, este estudo foi pautado no que seria mais conveniente para o Brasil, levando em consideração, como ponto de partida, o modelo da Central Nuclear Almirante Álvaro Alberto, quanto aos reatores Angra 1 e 2, e futuro reator Angra 3, bem como o parque industrial brasileiro atual. Procurou-se analisar uma situação dentro das possibilidades reais quanto ao tipo de casco de armazenagem mais apropriado para essa Central Nuclear, quanto à instalação via seca que possa ser construída no mesmo terreno mais adequado. 


\subsection{Casco para CNQ-PWR}

De toda a literatura estudada, a utilização de cascos para a armazenagem seca de CNQ colocados acima do nível do solo possibilita melhor mobilidade dos mesmos do que as outras formas de depósito, por exemplo, em silos horizontais ou poços (Hanson e Chollet, 2003; Roland et al., 2003; Transnucleaire, 2007; URNC, 2008). Esta é uma das maiores vantagens da utilização de cascos autóctones tipo multi-propósito.

O casco multi-propósito, embora mais caro, é mais conveniente que o de simples propósito, pois o mesmo casco serve tanto para transporte como para armazenagem (IAEA, 2000). Neste caso, o projeto de construção desse tipo de invólucro deve levar em consideração regras de segurança relativas a sua integridade, das diferentes características térmicas do CNQ e dos materiais usados, blindagens, criticalidade, fabricação e inspeção, durabilidade, forma de armazenagem e o tipo de transporte (Shappert 1998; Roland et al., 2003; NEA, 2005; ASME, 2007). Hoje em dia considera-se que a durabilidade de um casco autóctone para armazenagem seca de CNQ deva ser de 50 anos, ao menos (Haire et al., 2004).

Diferentes tipos e formatos de casco foram desenvolvidos no mundo, entre eles, os mais comuns são os metálicos e de concreto que podem ser prismáticos (menos comuns) (Ontário Power Generation, 2009) e cilíndricos. Cascos metálicos foram desenvolvidos no final da década de 1970 e são amplamente utilizados (Andersson e Andrews, 2001; IAEA, 2003; 2007) e dependendo do formato, podem armazenar entre 4 e 26 elementos PWR (DOE, 2004; NEA, 2005). Cascos de concreto começaram a ser desenvolvidos em meados de 1990 (Luz e Baltar, 2005; NAC, 2008). Estes últimos são bem mais robustos e possuem massa maior que os equivalentes metálicos. $\mathrm{Na}$ última década têm sido estudados cascos produzidos com outros tipos de materiais, como urânio exaurido, com o objetivo de diminuir o peso final do casco e porque possuem maior capacidade de blindagem embora seu custo seja muito alto. (Vossnacke et al., 2003; Matveev et al., 2006).

Os testes pelos quais os cascos devem passar com vistas ao licenciamento de sua construção e utilização datam da década de 80. Após sua aplicação para armazenagem e transporte, o licenciamento é periódico. Os procedimentos normalmente envolvem (DOE, 2004; NEA, 2005) tipos de testes pelos quais o casco deve passar (no mínimo todos os exigidos por norma); como os testes serão feitos; qual a quantidade de pessoas que participarão dos testes; o que a instalação de testes deverá possuir; qual será a previsão de segurança, inclusive com a utilização de EPIs (Equipamentos de Proteção Individual); 
previsão de sobressalentes para caso de dano de algum componente durante os testes; onde os resultados dos testes serão registrados. O cumprimento do procedimento proporcionará um desenvolvimento satisfatório dos testes, sem ocasionar surpresas fortuitas.

Para reduzir o calor gerado pelo CNQ por decaimento dos radioisótopos presentes, os elementos combustíveis devem permanecer em piscina de resfriamento por, ao menos, cinco anos para depois serem inseridos nos cascos de armazenagem. Este procedimento reduz o custo de construção do casco. Por este motivo, levar em conta as temperaturas do CNQ ao longo do tempo, após a retirada do núcleo do reator, em função do enriquecimento e do burnup são importantes para a concepção do projeto do casco com auxílio de métodos de cálculo numérico e analítico (Ikonen, 2005) e a priorização de vetores por meio do Processo Hierárquico Analítico (Saaty, 1980).

Um dos desafios que foram superados ao longo dos anos foi a secagem dos elementos combustíveis no momento de sua retirada do reator e inserção nos cascos. Este procedimento pode ser feito com inserção de gás quente (IAEA, 2003). Esta etapa é importante para reduzir o processo de corrosão dos materiais imediatamente próximos aos elementos combustíveis ali depositados (IAEA, 2003).

Outro fator importante é o fechamento dos cascos com vistas a armazenagem seca sem intercorrências futuras de vazamento de radionuclídeos para o meio ambiente. Neste panorama, foram desenvolvidas técnicas avançadas de soldagem por feixes de elétrons ou calor de fricção, que foram aproveitadas nas linhas de fabricação dos cascos, como na selagem das tampas (Andersson e Andrews, 2001).

A segurança dos cascos contra acidentes, incluindo acidentes aéreos, incêndios, explosões e certos tipos de ataques humanos têm sido amplamente discutida. Alguns trabalhos neste sentido têm sido desenvolvidos e alguns autores mostraram que os cascos não são resistentes à munição de combate, mas ainda proporcionam melhor proteção que em outro tipo de invólucro (Hirsch e Neumann, 2001; Pennington e Mcgough, 2002). Porém, possuem uma segurança elevada quanto aos incidentes e acidentes de transporte, e este nível de segurança é bastante melhorado quando a instalação de armazenagem protege os cascos da intempérie e da agressão física.

Quanto ao manuseio dos cascos carregados sob o aspecto da segurança, Best et al. (1982) patentearam um sistema de múltiplos munhões de elevação. Neste caso, uma das lições aprendidas durante os processos de testes para licenciamento, mostrou que a utilização de limitadores de impacto nas extremidades é altamente necessária. 
A durabilidade prevista para o sistema de armazenagem de Angra seria em princípio de 20 a 40 anos, como recomenda a USNRC (2009a) que poderia ser estendida em função de ajustes durante o projeto, naturalmente com conseqüências de custo maior para um benefício também maior.

Outro item bastante significativo no projeto do casco são os custos envolvidos na confecção e licenciamento de cascos autóctones. Esta análise tem sido feita há pelo menos três décadas por vários autores, entre eles Fairlie (2000), Earle (2002), Matveev et al. (2006). Após reunir as informações mais atualizadas encontradas na literatura e com subsídios de Metalprices (2009), calculou-se que o custo do casco de metal (aço), como o sugerido neste trabalho, para 21 elementos e produzido pelo parque industrial brasileiro, seria de US\$925.000,00. Se este casco fosse confeccionado apenas como invólucro de armazenagem, seu custo cairia para US\$564.250,00 a 795.500,00 e se esta armazenagem fosse feita em poços ou silos, o valor seria de US\$573.500,00 a 693.750,00 e US\$462.500,00 a 555.000,00, respectivamente. Para os três últimos, também deve ser considerado o custo da confecção de um casco de transporte, a ser somado ao custo da transferência para o local de armazenagem. (Held e Hintermeyer, 1978; Bunn et al, 2001; Earle, 2002). Quanto aos custos dos testes para o licenciamento, Halstead e Dilger (2006) apresentaram uma grade de custos e mostraram que em relação ao valor do casco somamse outros valores como de testes físicos, análise computacional, documentação que envolve os testes, participação de pessoal necessário, administração, revisão técnica, e outras contingências. O valor do casco, neste caso, pode quase triplicar. Contudo, uma vez licenciado, esse custo total se distribui entre os cascos adicionais que venham a ser fabricados a partir do mesmo projeto de construção.

\subsection{Armazenagem de CNQ}

Vários países adotaram a estratégia de armazenagem seca do CNQ, em cascos metálicos ou de concreto. A Inglaterra foi o primeiro país a adotar a armazenagem seca de CNQ, em 1972, e o Canadá, em 1975, portanto há quase 35 anos. Este processo gerou dezenas de trabalhos acadêmicos e patentes que têm sido apresentados em periódicos especializados e conferências promovidas por diversos órgãos internacionais e pela própria IAEA. Entre eles podem-se citar os trabalhos publicados nesta década como os de Ahmed et al. (2003), Biro e Rodna (2003), Coufal e Brzobohatý (2003), Hanson e Chollet (2003), Kulkarni et al. (2003), Lietava et al. (2003), Martínez e Gago (2003), Verdier et al. (2003), USNRC (2008) que possuem praticamente o mesmo ponto de vista quanto ao assunto. As 
diferenças são constatadas para cascos de simples propósito ou multi-propósito e a forma de armazená-los.

Na grande maioria dos países com reatores de potência comerciais, a tendência para armazenar CNQ em instalações secas tornou-se evidente pela indefinição de seu destino final, porque a construção de instalações de reprocessamento é muito cara e porque repositórios definitivos estão longe de existirem em todos os países que possuem CNQ. Fairlie (2000) afirma que a armazenagem seca de CNQ, em países sem programa de reprocessamento, tem assegurado impacto ao meio ambiente bem menor. Sabe-se que os estudos para a construção de um repositório definitivo para este combustível são muito demorados e caros e, até hoje, essa maioria não possui sequer a definição do local ideal e às vezes não possui nem terreno adequado. Muitos países operam suas centrais nucleares com combustível sob salvaguardas e a devolução desse CNQ deve ocorrer como o fez o Brasil na década de 90.

A armazenagem seca de CNQ em diversos países tem passado por modernizações quanto aos materiais usados em sua construção, modo de condicionamento dos cascos, novos equipamentos e deslocamento interno. Estas melhorias envolvem conhecimentos dos fundamentos científicos e tecnológicos dos reatores nucleares, o burnup, análise de blindagens e modelos de transporte de nêutrons, etc. (Glasstone e Sesonske, 1975; Duderstadt e Hamilton,1976; Cochran e Tsoulfanidis, 1992; USNRC, 2008).

Da literatura analisada observa-se que o método de armazenagem seca de CNQ, já considera o aumento das instalações existentes ou a criação de novas instalações (IAEA, 1999a; Coufal; Brzobohatý, 2003; IAEA, 2003; Shirai et al. em IAEA, 2007a; IAEA, 2006; IAEA, 2001; Lidskog e Andersson, 2002; Martinez e Gago, 2003; Indian Point, 2008). Com base na análise dos dados coletados, até hoje no mundo todo, pode-se optar por uma instalação úmida ou seca, ao caracterizar cada custo em categorias, analisar a economia dos valores envolvidos e chegar a uma concepção e valores totais ótimos (Held e Hintermeyer, 1978; IAEA, 1994). Este panorama engloba também o descomissionamento de centrais nucleares como preconizam IAEA (1988) e Cumo et al. (2004).

Várias Conferências têm abordado temas como a armazenagem seca de CNQ em suas diferentes versões e ultimamente tem sido dada ênfase aos acidentes e atentados terroristas, como citam Amaral et al.; Baggett e Brach; Goll et al.; Gregoric; Issard; Lietava; Solinac et al.; Tanaka; em seus trabalhos publicados pela IAEA (2007a). Atos 
terroristas fazem parte de todas as matérias sobre este assunto desde o atentado às torres gêmeas, em 2001, New York, EUA. Essa segurança durante a armazenagem requer que a contenção proporcionada pela instalação previna a liberação de produtos de fissão no meio ambiente, não só em situação normal de operação, como também em condições anormais como acidentes resultantes de falhas internas, do manuseio do CNQ dentro da instalação, ou externas, como atos terroristas (Ryhänen, 2000; IAEA, 2002; IAEA, 2003; Biro e Rodna, 2003; Coufal e Brzobohatý, 2003; Hanson e Chollet, 2003; Khan e King, 2003; Kulkarni et al., 2003; Lee et al., 2005; Zaporizhzhya Nuclear Power Plant, 2008; CNEN, 2008).

Outro fator preponderante a ser analisado é a estimativa dos custos de projeto e a construção das instalações de armazenagem de CNQ que devem considerar: insumos; custos da construção; acessos; todos os fatores relacionados à segurança durante toda a vida útil da instalação, incluindo o impacto de segurança relativo aos trabalhadores, o público e o meio-ambiente. Quanto ao item segurança devem ser considerados também os riscos radiológicos das pessoas e do meio ambiente. Por isso, existe a proposição de instalações de armazenagem seca do tipo “robustas”, ou seja, capazes de reduzir riscos radiológicos e resistir às intempéries (Thompson, 2003; National Research Council, 2006; IAEA, 2006).

O processo de licenciamento de uma instalação de armazenagem seca é outra fase importante no projeto de construção e manutenção, e o período entre o início e a autorização para a sua operacionalidade também devem entrar na estimativa de custos (Khan e King, 2003; DOE, 2004). No caso específico brasileiro, o CNQ gerado por Angra 2, por exemplo, necessitará de espaço adicional de armazenagem úmida, pois a piscina tem capacidade para apenas 15 anos de operação do reator (CNEN, 2007) e a armazenagem seca permitiria que o reator tivesse uma sobrevida que seria importante para o parque nuclear brasileiro.

Em 2003, a IAEA publicou em documento técnico um resumo das técnicas de monitoração em armazenagem seca, das práticas correntes e futuras aplicadas em alguns países como mostra a Tabela 24. Entre os países citados, a França, a Hungria e o Japão são os países que mais aplicam as práticas correntes para a maior parte das técnicas de acompanhamento da monitoração do CNQ em armazenagem seca. Desses países a Federação Russa é a única que planeja aplicar todas estas práticas no futuro. O burnup é a prática a ser desenvolvida no futuro pelos países citados, porque permitirá melhorar a 
capacidade de armazenagem de CNQ, especialmente de combustíveis altamente enriquecidos e com burnup alto.

Tabela 24. Resumo das técnicas de monitoração em armazenagem seca, práticas correntes e futuras, aplicadas em alguns países

\begin{tabular}{|c|c|c|c|c|c|c|c|c|c|c|}
\hline \multirow[b]{2}{*}{ Técnica } & \multicolumn{10}{|c|}{ País } \\
\hline & Canadá & França & Alemanha & Hungria & Japão & $\begin{array}{l}\text { República } \\
\text { da Coréia }\end{array}$ & $\begin{array}{l}\text { Fed. } \\
\text { Russa }\end{array}$ & Espanha & RU & EUA \\
\hline $\begin{array}{l}\text { Monitoração } \\
\text { da pressão }\end{array}$ & $\mathbf{F}$ & C & C & C & C & & $\mathbf{F}$ & C & & C \\
\hline $\begin{array}{l}\text { Amostragem } \\
\text { de gás de } \\
\text { fissão }\end{array}$ & $\mathbf{F}$ & & & C & C & & $\mathbf{F}$ & & $\mathbf{C}$ & \\
\hline $\begin{array}{l}\text { Medida de } \\
\text { Temperatura }\end{array}$ & C & C & & C & C & & & C & C & \\
\hline $\begin{array}{l}\text { Sistemas de } \\
\text { detecção da } \\
\text { radiação }\end{array}$ & C & C & C & C & C & C & $\mathbf{F}$ & C & C & C \\
\hline $\begin{array}{l}\text { Inspeção } \\
\text { visual }\end{array}$ & & C & & & & C & $\mathbf{F}$ & C & C & C \\
\hline $\begin{array}{l}\text { Amostragem } \\
\text { de gás não } \\
\text { ativo }\end{array}$ & $\mathbf{F}$ & C & & C & C & & $\mathbf{F}$ & & & C \\
\hline Burnup & & $\mathbf{F}$ & & & $\mathbf{F}$ & $\mathbf{F}$ & & $\mathbf{F}$ & & $\mathbf{F}$ \\
\hline
\end{tabular}

C: Prática Corrente; F: Prática Futura; RU: Reino Unido; EUA: Estados Unidos da América

Fonte: Adaptado de IAEA (2003) pág. 93

\subsection{Transporte de cascos}

A sistemática de transporte, desde a retirada do CNQ do reator até a chegada à instalação de armazenagem temporária pode ser complexa, dependendo do itinerário adotado, mesmo assim, a experiência quanto ao transporte do CNQ no mundo é muito grande, visto que desde 1972 o mesmo é realizado, com cascos de diferentes modelos. Se o país opta pela armazenagem em instalação localizada no próprio sítio do reator de origem do CNQ o projeto torna-se simplificado, diminui os percursos, a probabilidade de ocorrência de incidentes ou acidentes que possam causar danos às pessoas ou ao meio ambiente é minimizada (Romanato e Rzyski; 2003; Office of Civilian Radioactive Waste Management, 2004). 
Todos os modelos de cascos a serem fabricados devem ser licenciados por um organismo certificador. Os testes relacionados ao transporte de cascos são os mais abrangentes, visto que os mesmos poderão estar em contato mais próximo com o público na parte externa da instalação de armazenagem e esses testes têm seus custos. Um casco testado, aprovado e licenciado resultará numa linha de fabricação de mais cascos iguais que não necessitarão de mais testes.

A estimativa de um programa de testes para o licenciamento de um casco, como o proposto aqui, incluindo o valor do casco é da ordem de U\$2.400.000,00. Esse valor está baseado no porcentual do valor estabelecido por Halstead e Dilger (2006), para valores de testes em cascos de transporte em veículos rodoviários. Se forem utilizados dois cascos para os testes, um para estanqueidade e quedas, e outro para o teste térmico, aquele valor é dobrado. O custo do programa de testes pode ser diluído entre todos os cascos que serão construídos. De acordo com a presente proposição para armazenar todo o combustível de Angra serão necessários 340 cascos e o valor referente aos testes, por casco, resultaria em pouco mais de US\$14.000,00.

Não estão previstos grandes deslocamentos dos cascos de CNQ entre os reatores Angra 1, 2 e 3 e a instalação de armazenagem. Caso a instalação estivesse localizada em outro local, fora do sítio da central nuclear, o custo do transporte teria maior importância. O transporte deveria ser feito por terra por meio de rodovias ou ferrovias, ou ainda, por mar. Por causa do peso do casco, o mais indicado seria o transporte ferroviário, e precisaria ser estabelecida uma malha ferroviária da região do reator para a região da instalação, mas ainda o transporte rodoviário com veículos destinados para grandes cargas seriam mais aceitáveis. A opção marítima seria intermediária, visto que após o desembarque no porto, seria necessário outro tipo de transporte (rodoviário ou ferroviário).

Para finalizar, deve-se considerar que as conclusões às quais se chegou neste estudo, em que se avaliou diferentes tecnologias mundialmente desenvolvidas para os cascos e instalações de armazenagem, não estão totalmente decididas, pois até que o Brasil comece a fabricar cascos para CNQ, podem ser encontradas outras soluções em gestão de combustível queimado, em função de materiais mais modernos, diferentes modelos de combustível, burnup maior, práticas de engenharia com novas concepções, etc. A abordagem considerada faz parte de um processo dinâmico e pode ter seus conceitos modificados ao longo do tempo. Alguns tópicos aqui expostos podem tornar-se absolutamente ultrapassados no futuro próximo e outros, deverão ser considerados em seu 
lugar. Esta constatação é um resultado importante neste estudo. O propósito foi assinalar alguns itens que devem ser analisados quando os projetos de construção estiverem sendo confrontados com a tarefa de avaliação e selecionar uma abordagem moderna e funcional de gestão do combustível irradiado no Brasil. 
6 CONCLUSÕES 


\section{CONCLUSÕES}

No programa nuclear brasileiro diversos estudos concernentes à etapa final do ciclo do combustível nuclear estão sendo desenvolvidos. A gerência do combustível nuclear queimado (CNQ) demanda ainda muita pesquisa e desenvolvimento.

No momento, nenhuma empresa no Brasil desenvolve e produz cascos de armazenagem para CNQ de reatores de potência, portanto, o país não possui esse tipo de recipiente autóctone que permita manter o CNQ isolado com segurança e por longo tempo. É necessário lembrar, no entanto que diversos estudos sobre cascos de armazenagem estão em andamento.

Após análise do estado da arte existente no mundo para estudar as alternativas viáveis que subsidiem a confecção de um casco totalmente nacional para armazenagem seca do CNQ de reatores PWR e que sirva também como meio de transporte, bem como, a apresentação de subsídios para o projeto da instalação de armazenagem, pode-se afirmar que:

\section{Quanto ao casco}

1. O tipo de armazenagem para combustível nuclear queimado de reatores PWR, aqui proposto, é inédito no Brasil

2. O melhor material estrutural para o modelo de casco para armazenagem de CNQ proposto é o metal (aço) com revestimentos internos de chumbo e polietileno para blindagem de radiação gama e nêutrons.

3. Nos cálculos efetuados constatou-se que em vez do aço, podem ser usados outros materiais, mas que apresentam inconvenientes específicos, por exemplo, o urânio exaurido tem custo muito elevado e é material salvaguardado, e o concreto, para proporcionar a mesma blindagem que o aço, requer uma massa bem maior. Neste último caso, o projeto do casco deve ser adequado, a instalação de armazenagem deve ter piso mais reforçado e os sistemas de movimentação apropriados à massa do casco;

4. No casco proposto, podem ser armazenados 21 elementos CNQ-PWR com taxa máxima de burnup de $33 \mathrm{G} \mathrm{Wd/tU}$, após resfriamento em piscina durante 5 anos. A quantidade de elementos aliada à geometria dos cestos, aos materiais utilizados na confecção desses cestos e aos cascos, previnem a possibilidade de ocorrência de criticalidade. 
5. Após levantamento efetuado no parque industrial brasileiro verificou-se que a indústria brasileira está totalmente apta para construir o casco de aço para o CNQ-PWR nacional, quaisquer que sejam os processos adotados em sua confecção, pois a tecnologia a ser utilizada é de domínio público.

6. Nesse estudo, foram levados em conta os perfis e as dimensões dos CNQ utilizados nas usinas Angra 1, 2 e na futura usina Angra 3, para a proposta do casco de armazenagem do CNQ. Os cascos tem dimensões únicas para armazenaar ambos tipos de CNQ.

\section{Quanto à instalação}

1 Uma instalação de armazenagem seca é mais vantajosa que a armazenagem úmida, pois:

a) a corrosão dos elementos armazenados em via seca é menor que os armazenados em via úmida;

b) após a inserção do CNQ no casco de armazenagem, não haverá mais danos resultantes do manuseio do combustível e o casco poderá ser movimentado/deslocado dentro da instalação de armazenagem e durante o transporte externo;

c) o resfriamento do CNQ no casco em armazenagem seca é realizado de forma passiva. Neste caso o controle do sistema da troca de calor com o meioambiente é mais simples que na armazenagem úmida.

2. A instalação de armazenagem deverá ser fechada para aumentar a proteção física dos cascos contra a intempérie, acesso não permitido, acidentes e atos terroristas;

3. O piso deve ser reforçado de acordo com a distribuição de massa dos cascos, isto é poder sustentar, sem ceder, $35.200 \mathrm{~kg} / \mathrm{m}^{2}$;

4. A instalação poderá ser construída por módulos de modo que o investimento inicial seja menor.

5. A movimentação dos cascos dentro da instalação de armazenagem deverá ser feita por veículos transportadores, como o sugerido nesse trabalho (Figura 74);

6. Levou-se em conta o terreno da usina nuclear de Angra para sugerir uma instalação de armazenagem seca para o CNQ.

7. De acordo com os cálculos efetuados para o CNQ-PWR de Angra, a instalação de armazenagem será capaz de guardar todo o CNQ gerado nesta instalação por 
um período mínimo de 20 anos até que as autoridades competentes definam o destino final do combustível acumulado. 
7 ANEXOS 


\section{ANEXO A \\ TABELAS DE CALOR DE DECAIMENTO DO CNQ (USNRC, 1999)}

Table C.10 PWR decay heat rates (W/kgU) of light elements, actinides, and fission products,

for specific power $=18 \mathrm{~kW} / \mathrm{kgU}$, Set 1

\begin{tabular}{|c|c|c|c|c|c|c|}
\hline \multicolumn{3}{|c|}{ Burnup = $25 \mathrm{MWd} / \mathrm{kgU}$} & \multirow{2}{*}{$\begin{array}{c}\text { Cooling } \\
\text { Time, years }\end{array}$} & \multicolumn{3}{|c|}{ Burnup = $30 \mathrm{MWd} / \mathrm{kgU}$} \\
\hline Light El & Actinides & Fis Prod & & Light El & Actinides & Fis Prod \\
\hline $1.198 \mathrm{E}-01$ & 4.377E-01 & $5.389 \mathrm{E}+00$ & 1.0 & $1.269 \mathrm{E}-01$ & 5.912E-01 & $5.855 \mathrm{E}+00$ \\
\hline 1.062E-01 & 3.002E-01 & $4.079 \mathrm{E}+00$ & 1.4 & 1.130E-01 & 4.091E-01 & $4.487 \mathrm{E}+00$ \\
\hline 9.579E-02 & 2.045E-01 & $2.908 \mathrm{E}+00$ & 2.0 & $1.021 \mathrm{E}-01$ & 2.814E-01 & $3.249 \mathrm{E}+00$ \\
\hline 8.550E-02 & $1.620 \mathrm{E}-01$ & $2.006 \mathrm{E}+00$ & 2.8 & 9.113E-02 & 2.241E-01 & $2.286 \mathrm{E}+00$ \\
\hline 7.262E-02 & 1.505E-01 & $1.328 \mathrm{E}+00$ & 4.0 & 7.742E-02 & 2.072E-01 & $1.550 \mathrm{E}+00$ \\
\hline 6.351E-02 & 1.515E-01 & $1.053 \mathrm{E}+00$ & 5.0 & 6.771E-02 & 2.071E-01 & $1.245 \mathrm{E}+00$ \\
\hline 4.369E-02 & 1.567E-01 & 8.031E-01 & 7.0 & 5.191E-02 & 2.116E-01 & 9.597E-01 \\
\hline 3.275E-02 & 1.642E-01 & 6.609E-01 & 10.0 & 3.492E-02 & 2.182E-01 & 7.905E-01 \\
\hline 1.696E-02 & 1.739E-01 & $5.530 \mathrm{E}-01$ & 15.0 & 1.808E-02 & 2.264E-01 & $6.600 \mathrm{E}-01$ \\
\hline 8.806E-03 & 1.807E-01 & 4.822E-01 & 20.0 & 9.389E-03 & 2.318E-01 & 5.769E-01 \\
\hline 4.589E-03 & 1.855E-01 & 4.247E-01 & 25.0 & 4.894E-03 & 2.351E-01 & 5.060E-01 \\
\hline 2.406E-03 & 1.885E-01 & 3.755E-01 & 30.0 & $2.566 \mathrm{E}-03$ & 2.367E-01 & 4.471E-01 \\
\hline 6.872E-04 & $1.910 \mathrm{E}-01$ & 2.948E-01 & 40.0 & 7.342E-04 & 2.366E-01 & 3.509E-01 \\
\hline 2.235E-04 & 1.905E-01 & 2.323E-01 & 50.0 & 2.399E-04 & 2.336E-01 & 2.764E-01 \\
\hline 9.681E-05 & 1.882E-01 & $1.834 \mathrm{E}-01$ & 60.0 & 1.047E-04 & 2.290E-01 & 2.182E-01 \\
\hline 6.071E-05 & 1.849E-01 & $1.450 \mathrm{E}-01$ & 70.0 & 6.620E-05 & 2.238E-01 & $1.724 \mathrm{E}-01$ \\
\hline 4.912E-05 & 1.812E-01 & 1.147E-01 & 80.0 & 5.379E-05 & 2.183E-01 & 1.364E-01 \\
\hline 4.425E-05 & 1.772E-01 & $9.072 \mathrm{E}-02$ & 90.0 & 4.856E-05 & 2.127E-01 & 1.079E-01 \\
\hline 4.133E-05 & 1.733E-01 & 7.180E-02 & 100.0 & 4.541E-05 & 2.072E-01 & 8.539E-02 \\
\hline 3.904E-05 & 1.693E-01 & $5.684 \mathrm{E}-02$ & 110.0 & 4.293E-05 & 2.019E-01 & 6.795E-02 \\
\hline
\end{tabular}

Table C.11 PWR decay heat rates (W/kgU) of light elements, actinides, and fission products, for specific power $=18 \mathrm{~kW} / \mathrm{kgU}$, Set 2

\begin{tabular}{|c|c|c|c|c|c|c|}
\hline \multicolumn{3}{|c|}{ Burnup = $35 \mathrm{MWd} / \mathrm{kgU}$} & \multirow{2}{*}{$\begin{array}{c}\text { Cooling } \\
\text { Time, years }\end{array}$} & \multicolumn{3}{|c|}{ Burnup $=40 \mathrm{MWd} / \mathrm{kgU}$} \\
\hline Light El & Actinides & Fis Prod & & Light El & Actinides & Fis Prod \\
\hline 1.319E-01 & 7.602E-01 & $6.194 \mathrm{E}+00$ & 1.0 & $1.365 \mathrm{E}-01$ & 9.353E-01 & $6.590 \mathrm{E}+00$ \\
\hline 1.177E-01 & 5.305E-01 & $5.800 \mathrm{E}+00$ & 1.4 & $1.221 \mathrm{E}-01$ & 6.608E-01 & $5.155 \mathrm{E}+00$ \\
\hline 1.064E-01 & 3.696E-01 & $3.528 \mathrm{E}+00$ & 2.0 & $1.105 \mathrm{E}-01$ & 4.680E-01 & $3.835 \mathrm{E}+00$ \\
\hline 9.506E-02 & 2.965E-01 & $2.592 \mathrm{E}+00$ & 2.8 & $9.870 \mathrm{E}-02$ & 3.797E-01 & $2.785 E+00$ \\
\hline 8.077E-02 & 2.736E-01 & $1.754 \mathrm{E}+00$ & 4.0 & 8.386E-02 & 3.507E-01 & $1.963 \mathrm{E}+00$ \\
\hline 7.064E-02 & 2.721E-01 & $1.426 \mathrm{E}+00$ & 5.0 & 7.335E-02 & 3.476E-01 & $1.609 \mathrm{E}+00$ \\
\hline 5.416E-02 & 2.751E-01 & $1.110 \mathrm{E}+00$ & 7.0 & 5.623E-02 & 3.486E-01 & $1.216 \mathrm{E}+00$ \\
\hline 3.643E-02 & 2.798E-01 & $9.162 \mathrm{E}-01$ & 10.0 & 3.783E-02 & 3.508E-01 & $1.041 \mathrm{E}+00$ \\
\hline 1.887E-02 & 2.852E-01 & 7.640E-01 & 15.0 & 1.959E-02 & 3.522E-01 & 8.670E-01 \\
\hline 9.797E-03 & 2.879E-01 & 6.649E-01 & 20.0 & 1.017E-02 & 3.515E-01 & 7.540E-01 \\
\hline 5.108E-03 & 2.888E-01 & $5.850 \mathrm{E}-01$ & 25.0 & 5.305E-03 & 3.492E-01 & 6.630E-01 \\
\hline 2.680E-03 & 2.882E-01 & 5.167E-01 & 30.0 & 2.784E-03 & 3.457E-01 & 5.854E-01 \\
\hline 7.683E-04 & 2.841E-01 & 4.052E-01 & 40.0 & 7.997E-04 & 3.367E-01 & 4.590E-01 \\
\hline 2.525E-04 & 2.778E-01 & 3.191E-01 & 50.0 & 2.641E-04 & 3.264E-01 & 3.614E-01 \\
\hline $1.114 \mathrm{E}-04$ & 2.705E-01 & $2.518 \mathrm{E}-01$ & 60.0 & $1.175 \mathrm{E}-04$ & 3.156E-01 & 2.852E-01 \\
\hline 7.106E-05 & 2.628E-01 & $1.990 \mathrm{E}-01$ & 70.0 & 7.559E-05 & 3.049E-01 & 2.253E-01 \\
\hline 5.804E-05 & 2.551E-01 & $1.574 \mathrm{E}-01$ & 80.0 & $6.201 \mathrm{E}-05$ & 2.947E-01 & 1.782E-01 \\
\hline $5.251 \mathrm{E}-05$ & 2.476E-01 & $1.245 \mathrm{E}-01$ & 90.0 & $5.621 \mathrm{E}-05$ & 2.849E-01 & $1.410 \mathrm{E}-01$ \\
\hline 4.916E-05 & 2.404E-01 & $9.855 \mathrm{E}-02$ & 100.0 & 5.267E-05 & $2.758 \mathrm{E}-01$ & 1.116E-01 \\
\hline 4.625E-05 & 2.335E-01 & 7.801E-02 & 110.0 & 4.989E-05 & 2.672E-01 & 8.831E-02 \\
\hline
\end{tabular}


Table C.13 PWR decay heat rates (W/kgU) of light elements, actinides, and fission products,

for specific power $=28 \mathrm{~kW} / \mathrm{kgU}$, Set 1

\begin{tabular}{|c|c|c|c|c|c|c|}
\hline \multicolumn{3}{|c|}{ Burnup $=25 \mathrm{MWd} / \mathrm{kgU}$} & \multirow{2}{*}{$\begin{array}{l}\text { Cooling } \\
\text { Time, years }\end{array}$} & \multicolumn{3}{|c|}{ Burnup = $30 \mathrm{MWd} / \mathrm{kgU}$} \\
\hline Light El & Actinides & Fis Prod & & Light El & Actinides & Fis Prod \\
\hline $1.361 \mathrm{E}-01$ & 3.874E-01 & $7.036 \mathrm{E}+00$ & 1.0 & $1.461 \mathrm{E}-01$ & $5.340 \mathrm{E}-01$ & $7.710 \mathrm{E}+00$ \\
\hline 1.181E-01 & 2.700E-01 & $5.205 E+00$ & 1.4 & $1.275 \mathrm{E}-01$ & 3.734E-01 & $5.772 \mathrm{E}+00$ \\
\hline $1.058 \mathrm{E}-01$ & 1.885E-01 & $3.606 \mathrm{E}+00$ & 2.0 & $1.144 \mathrm{E}-01$ & 2.615E-01 & $4.056 \mathrm{E}+00$ \\
\hline $9.420 \mathrm{E}-02$ & 1.527E-01 & $2.394 \mathrm{E}+00$ & 2.8 & $1.020 \mathrm{E}-01$ & 2.115E-01 & $2.741 \mathrm{E}+00$ \\
\hline 7.992E-02 & 1.436E-01 & $1.500 \mathrm{E}+00$ & 4.0 & 8.635E-02 & 1.973E-01 & $1.759 E+00$ \\
\hline $6.986 \mathrm{E}-02$ & $1.450 \mathrm{E}-01$ & $1.148 \mathrm{E}+00$ & 5.0 & 7.564E-02 & 1.977E-01 & $1.364 \mathrm{E}+00$ \\
\hline 5.353E-02 & $1.506 \mathrm{E}-01$ & 8.410E-01 & 7.0 & $5.796 \mathrm{E}-02$ & $2.026 \mathrm{E}-01$ & $1.010 \mathrm{E}+00$ \\
\hline $3.600 \mathrm{E}-02$ & 1.583E-01 & $6.791 \mathrm{E}-01$ & 10.0 & $3.898 \mathrm{E}-02$ & 2.096E-01 & 8.159E-01 \\
\hline $1.864 \mathrm{E}-02$ & 1.685E-01 & 5.645E-01 & 15.0 & 2.018E-02 & 2.184E-01 & 6.764E-01 \\
\hline $9.672 \mathrm{E}-03$ & 1.757E-01 & 4.916E-01 & 20.0 & $1.047 \mathrm{E}-02$ & 2.243E-01 & 5.883E-01 \\
\hline $5.038 \mathrm{E}-03$ & $1.808 \mathrm{E}-01$ & 4.329E-01 & 25.0 & $5.454 \mathrm{E}-03$ & $2.280 \mathrm{E}-01$ & 5.176E-01 \\
\hline 2.638E-03 & $1.841 \mathrm{E}-01$ & 3.826E-01 & 30.0 & 2.857E-03 & 2.300E-01 & 4.573E-01 \\
\hline 7.497E-04 & $1.871 \mathrm{E}-01$ & 3.004E-01 & 40.0 & 8.124E-04 & 2.306E-01 & 3.586E-01 \\
\hline $2.405 \mathrm{E}-04$ & $1.870 \mathrm{E}-01$ & 2.367E-01 & 50.0 & 2.611E-04 & 2.281E-01 & 2.836E-01 \\
\hline $1.015 \mathrm{E}-04$ & $1.850 \mathrm{E}-01$ & $1.896 \mathrm{E}-01$ & 60.0 & $1.106 \mathrm{E}-04$ & $2.241 \mathrm{E}-01$ & 2.231E-01 \\
\hline $6.210 \mathrm{E}-05$ & 1.820E-01 & 1.477E-01 & 70.0 & 6.793E-05 & 2.193E-01 & 1.763E-01 \\
\hline 4.916E-05 & $1.786 \mathrm{E}-01$ & $1.168 \mathrm{E}-01$ & 80.0 & $5.440 \mathrm{E}-05$ & $2.141 \mathrm{E}-01$ & $1.394 \mathrm{E}-01$ \\
\hline $4.450 \mathrm{E}-05$ & 1.749E-01 & $9.243 \mathrm{E}-02$ & 90.0 & 4.886E-05 & 2.089E-01 & 1.103E-01 \\
\hline $4.150 \mathrm{E}-05$ & $1.711 \mathrm{E}-01$ & 7.315E-02 & 100.0 & $5.561 \mathrm{E}-05$ & $2.038 \mathrm{E}-01$ & 8.730E-02 \\
\hline 3.919E-05 & $1.674 \mathrm{E}-01$ & $5.791 \mathrm{E}-02$ & 110.0 & 4.311E-05 & $1.988 \mathrm{E}-01$ & $6.911 \mathrm{E}-02$ \\
\hline
\end{tabular}

Table C.14 PWR decay heat rates (W/kgU) of light elements, actinides, and fission products,

for specific power $=28 \mathrm{~kW} / \mathrm{kgU}$, Set 2

\begin{tabular}{|c|c|c|c|c|c|c|}
\hline \multicolumn{3}{|c|}{ Burnup = $35 \mathrm{MWd} / \mathrm{kgU}$} & \multirow{2}{*}{$\begin{array}{c}\text { Cooling } \\
\text { Time, years }\end{array}$} & \multicolumn{3}{|c|}{ Burnup = $40 \mathrm{MWd} / \mathrm{kgU}$} \\
\hline Light El & Actinides & Fis Prod & & Light El & Actinides & Fis Prod \\
\hline 1.593E-01 & 6.960E-01 & $8.205 E+00$ & 1.0 & 1.613E-01 & 8.674E-01 & $8.747 \mathrm{E}+00$ \\
\hline 1.351E-01 & 4.903E-01 & $6.211 \mathrm{E}+00$ & 1.4 & $1.420 \mathrm{E}-01$ & 6.170E-01 & $6.682 \mathrm{E}+00$ \\
\hline 1.214E-01 & 3.464E-01 & $4.426 \mathrm{E}+00$ & 2.0 & $1.278 \mathrm{E}-01$ & 4.412E-01 & $4.816 \mathrm{E}+00$ \\
\hline $1.082 \mathrm{E}-01$ & 2.812E-01 & $3.046 \mathrm{E}+00$ & 2.8 & $1.139 \mathrm{E}-01$ & 3.609E-01 & $3.360 \mathrm{E}+00$ \\
\hline $9.182 \mathrm{E}-02$ & 2.612E-01 & $1.999 \mathrm{E}+00$ & 4.0 & $9.670 \mathrm{E}-02$ & 3.348E-01 & $2.244 \mathrm{E}+00$ \\
\hline 8.028E-02 & 2.603E-01 & $1.570 \mathrm{E}+00$ & 5.0 & 8.455E-02 & 3.322E-01 & $1.778 \mathrm{E}+00$ \\
\hline $6.151 \mathrm{E}-02$ & 2.637E-01 & $1.175 \mathrm{E}+00$ & 7.0 & 6.479E-02 & 3.338E-01 & $1.341 \mathrm{E}+00$ \\
\hline 4.137E-02 & 2.689E-01 & $9.705 \mathrm{E}-01$ & 10.0 & 4.357E-02 & $3.365 \mathrm{E}-01$ & $1.085 \mathrm{E}+00$ \\
\hline $2.141 \mathrm{E}-02$ & 2.749E-01 & 7.863E-01 & 15.0 & $2.255 \mathrm{E}-02$ & 3.387E-01 & 8.958E-01 \\
\hline $1.111 \mathrm{E}-02$ & 2.783E-01 & 6.832E-01 & 20.0 & $1.171 \mathrm{E}-02$ & 3.387E-01 & 7.776E-01 \\
\hline 5.789E-03 & 2.797E-01 & 6.008E-01 & 25.0 & 6.098E-03 & 3.371E-01 & 6.835E-01 \\
\hline 3.033E-03 & 2.796E-01 & 5.306E-01 & 30.0 & 3.195E-03 & 3.342E-01 & 6.034E-01 \\
\hline 8.632E-04 & 2.783E-01 & 4.161E-01 & 40.0 & $9.102 \mathrm{E}-04$ & $3.263 \mathrm{E}-01$ & 4.730E-01 \\
\hline $2.782 \mathrm{E}-04$ & $2.707 \mathrm{E}-01$ & $3.276 \mathrm{E}-01$ & 50.0 & $2.940 \mathrm{E}-04$ & $3.168 \mathrm{E}-01$ & 3.723E-01 \\
\hline 1.185E-04 & 2.640E-01 & 2.586E-01 & 60.0 & $1.258 \mathrm{E}-04$ & 3.068E-01 & 2.938E-01 \\
\hline 7.314E-05 & 2.568E-01 & 2.043E-01 & 70.0 & 7.803E-05 & 2.969E-01 & 2.322E-01 \\
\hline 5.877E-05 & $2.496 \mathrm{E}-01$ & $1.616 \mathrm{E}-01$ & 80.0 & $6.286 \mathrm{E}-05$ & 2.873E-01 & $1.846 \mathrm{E}-01$ \\
\hline 5.287E-05 & $2.426 \mathrm{E}-01$ & $1.278 \mathrm{E}-01$ & 90.0 & 5.663E-05 & 2.782E-01 & 1.452E-01 \\
\hline 4.940E-05 & 2.353E-01 & $1.012 \mathrm{E}-01$ & 100.0 & 5.295E-05 & 2.695E-01 & 1.149E-01 \\
\hline 4.673E-05 & 2.294E-01 & 8.008E-02 & 110.0 & 5.012E-05 & 2.614E-01 & 9.098E-02 \\
\hline
\end{tabular}


Table C.16 PWR decay heat rates (W/kgU) of light elements, actinides, and fission products,

for specific power $=40 \mathrm{~kW} / \mathrm{kgU}$, Set 1

\begin{tabular}{|c|c|c|c|c|c|c|}
\hline \multicolumn{3}{|c|}{ Burnup $=25 \mathrm{MWd} / \mathrm{kgU}$} & \multirow{2}{*}{$\begin{array}{l}\text { Cooling } \\
\text { Time, years }\end{array}$} & \multicolumn{3}{|c|}{ Burnup = $30 \mathrm{MWd} / \mathrm{kgU}$} \\
\hline Light El & Actinides & Fis Prod & & Light El & Actinides & Fis Prod \\
\hline $1.485 \mathrm{E}-01$ & 3.419E-01 & $8.456 \mathrm{E}+00$ & 1.0 & $1.607 \mathrm{E}-01$ & $4.800 \mathrm{E}-01$ & $9.412 \mathrm{E}+00$ \\
\hline $1.259 \mathrm{E}-01$ & 2.435E-01 & $6.145 \mathrm{E}+00$ & 1.4 & $1.374 \mathrm{E}-01$ & 3.420E-01 & $6.921 E+00$ \\
\hline 1.119E-01 & $1.754 \mathrm{E}-01$ & $4.175 E+00$ & 2.0 & $1.224 \mathrm{E}-01$ & 2.459E-01 & $4.761 \mathrm{E}+00$ \\
\hline $9.944 \mathrm{E}-02$ & $1.458 \mathrm{E}-01$ & $2.702 \mathrm{E}+00$ & 2.8 & $1.088 \mathrm{E}-01$ & 2.033E-01 & $3.129 \mathrm{E}+00$ \\
\hline 8.428E-02 & 1.389E-01 & $1.670 \mathrm{E}+00$ & 4.0 & $9.225 E-02$ & 1.917E-01 & $1.928 \mathrm{E}+00$ \\
\hline 7.365E-02 & $1.406 \mathrm{E}-01$ & $1.215 E+00$ & 5.0 & 8.061E-02 & $1.926 \mathrm{E}-01$ & $1.455 \mathrm{E}+00$ \\
\hline $5.641 \mathrm{E}-02$ & $1.463 \mathrm{E}-01$ & 8.646E-01 & 7.0 & 6.175E-02 & $1.977 \mathrm{E}-01$ & $1.045 \mathrm{E}+00$ \\
\hline 3.793E-02 & 1.543E-01 & $6.686 \mathrm{E}-01$ & 10.0 & 4.152E-02 & 2.049E-01 & 8.315E-01 \\
\hline $1.963 \mathrm{E}-02$ & 1.646E-01 & $5.700 \mathrm{E}-01$ & 15.0 & 2.148E-02 & $2.140 \mathrm{E}-01$ & 6.859E-01 \\
\hline 1.019E-02 & $1.721 \mathrm{E}-01$ & $4.960 \mathrm{E}-01$ & 20.0 & 1.115E-02 & 2.203E-01 & $5.960 \mathrm{E}-01$ \\
\hline $5.304 \mathrm{E}-03$ & 1.773E-01 & 4.367E-01 & 25.0 & 5.805E-03 & 2.242E-01 & 5.243E-01 \\
\hline $2.776 \mathrm{E}-03$ & 1.808E-01 & 3.859E-01 & 30.0 & $3.038 \mathrm{E}-03$ & 2.265E-01 & 4.631E-01 \\
\hline 7.867E-04 & $1.841 \mathrm{E}-01$ & $3.030 \mathrm{E}-01$ & 40.0 & 8.612E-04 & 2.274E-01 & 3.633E-01 \\
\hline $2.505 \mathrm{E}-04$ & $1.842 \mathrm{E}-01$ & 2.387E-01 & 50.0 & 2.743E-04 & 2.253E-01 & 2.862E-01 \\
\hline $1.042 \mathrm{E}-04$ & 1.825E-01 & $1.884 \mathrm{E}-01$ & 60.0 & $1.143 \mathrm{E}-04$ & 2.216E-01 & 2.259E-01 \\
\hline 6.287E-05 & 1.797E-01 & 1.489E-01 & 70.0 & $6.902 \mathrm{E}-05$ & $2.170 \mathrm{E}-01$ & 1.785E-01 \\
\hline 4.985E-05 & $1.764 \mathrm{E}-01$ & $1.178 \mathrm{E}-01$ & 80.0 & $5.479 \mathrm{E}-05$ & $2.120 \mathrm{E}-01$ & 1.412E-01 \\
\hline 4.459E-05 & $1.728 \mathrm{E}-01$ & $9.320 \mathrm{E}-02$ & 90.0 & 4.905E-05 & 2.070E-01 & $1.117 \mathrm{E}-01$ \\
\hline 4.155E-05 & 1.692E-01 & 7.376E-02 & 100.0 & $4.574 \mathrm{E}-05$ & $2.020 \mathrm{E}-01$ & 8.839E-02 \\
\hline 3.923E-05 & $1.656 \mathrm{E}-01$ & $5.839 \mathrm{E}-02$ & 110.0 & 4.322E-05 & $1.972 \mathrm{E}-01$ & 6.997E-02 \\
\hline
\end{tabular}

Table C.17 PWR decay heat rates (W/kgU) of light elements, actinides, and fission products,

for specific power $=40 \mathrm{~kW} / \mathrm{kgU}$, Set 2

\begin{tabular}{|c|c|c|c|c|c|c|}
\hline \multicolumn{3}{|c|}{ Burnup = $35 \mathrm{MWd} / \mathrm{kgU}$} & \multirow{2}{*}{$\begin{array}{c}\text { Cooling } \\
\text { Time, years }\end{array}$} & \multicolumn{3}{|c|}{ Burnup = $40 \mathrm{MWd} / \mathrm{kgU}$} \\
\hline Light El & Actinides & Fis Prod & & Light El & Actinides & Fis Prod \\
\hline 1.706E-01 & 6.341E-01 & $1.010 \mathrm{E}+01$ & 1.0 & $1.800 \mathrm{E}-01$ & 7.998E-01 & $1.084 \mathrm{E}+01$ \\
\hline 1.469E-01 & 4.538E-01 & $7.510 \mathrm{E}+00$ & 1.4 & 1.557E-01 & 5.766E-01 & $8.131 E+00$ \\
\hline 1.311E-01 & 3.277E-01 & $5.233 E+00$ & 2.0 & 1.393E-01 & 4.201E-01 & $5.725 \mathrm{E}+00$ \\
\hline $1.167 \mathrm{E}-01$ & $2.709 \mathrm{E}-01$ & $3.496 \mathrm{E}+00$ & 2.8 & $1.239 \mathrm{E}-01$ & $3.487 \mathrm{E}-01$ & $3.873 \mathrm{E}+00$ \\
\hline $9.891 \mathrm{E}-02$ & $2.538 \mathrm{E}-01$ & $2.201 \mathrm{E}+00$ & 4.0 & $1.051 \mathrm{E}-01$ & $3.258 \mathrm{E}-01$ & $2.479 \mathrm{E}+00$ \\
\hline 8.644E-02 & 2.534E-01 & $1.681 \mathrm{E}+00$ & 5.0 & 9.183E-02 & 3.238E-01 & $1.911 \mathrm{E}+00$ \\
\hline $6.621 \mathrm{E}-02$ & 2.571E-01 & $1.220 \mathrm{E}+00$ & 7.0 & 7.034E-02 & 3.257E-01 & $1.397 \mathrm{E}+00$ \\
\hline $4.452 \mathrm{E}-02$ & $2.626 \mathrm{E}-01$ & $9.713 \mathrm{E}-01$ & 10.0 & $4.729 \mathrm{E}-02$ & $3.287 \mathrm{E}-01$ & $1.112 \mathrm{E}+00$ \\
\hline 2.304E-02 & 2.689E-01 & 7.990E-01 & 15.0 & 2.447E-02 & 3.314E-01 & $9.125 \mathrm{E}-01$ \\
\hline 1.195E-02 & 2.726E-01 & 6.934E-01 & 20.0 & $1.270 \mathrm{E}-02$ & 3.318E-01 & 7.911E-01 \\
\hline 6.224E-03 & 2.743E-01 & 6.096E-01 & 25.0 & 6.612E-03 & 3.306E-01 & 6.951E-01 \\
\hline 3.258E-03 & 2.745E-01 & 5.832E-01 & 30.0 & $3.461 \mathrm{E}-03$ & 3.281E-01 & 6.136E-01 \\
\hline $9.238 \mathrm{E}-04$ & $2.717 \mathrm{E}-01$ & $4.220 \mathrm{E}-01$ & 40.0 & $9.818 \mathrm{E}-04$ & $3.207 \mathrm{E}-01$ & 4.809E-01 \\
\hline 2.946E-04 & 2.665E-01 & 3.323E-01 & 50.0 & $3.134 \mathrm{E}-04$ & 3.117E-01 & 3.786E-01 \\
\hline $1.230 \mathrm{E}-04$ & 2.601E-01 & 2.622E-01 & 60.0 & $1.311 \mathrm{E}-04$ & 3.022E-01 & 2.987E-01 \\
\hline 7.449E-05 & 2.533E-01 & 2.072E-01 & 70.0 & 7.960E-05 & 2.927E-01 & 2.360E-01 \\
\hline 5.924E-05 & $2.464 \mathrm{E}-01$ & $1.639 \mathrm{E}-01$ & 80.0 & 6.340E-05 & 2.834E-01 & $1.866 \mathrm{E}-01$ \\
\hline 5.310E-05 & 2.396E-01 & $1.296 \mathrm{E}-01$ & 90.0 & 5.688E-05 & 2.746E-01 & $1.477 \mathrm{E}-01$ \\
\hline 4.956E-05 & 2.331E-01 & $1.026 \mathrm{E}-01$ & 100.0 & 5.313E-05 & 2.663E-01 & 1.169E-01 \\
\hline 4.686E-05 & 2.268E-01 & 8.121E-02 & 110.0 & 5.027E-05 & 2.585E-01 & 9.249E-02 \\
\hline
\end{tabular}


ANEXO B

\section{NORMAS ALEMÃS USADAS EM PROJETOS DE CASCOS METÁLICOS}

\begin{tabular}{|c|c|c|c|c|}
\hline Componente & $\begin{array}{c}\text { Projeto / } \\
\text { manufatura }\end{array}$ & Material & Solda & Controle e testes \\
\hline Corpo do casco & $\begin{array}{l}\text { Guias BAM } \\
\text { KTA 3201-2 }\end{array}$ & WS 0.7040-04 & N/A & $\begin{array}{c}\text { TRV } 006 \\
\text { DIN EN } 10204 \\
\text { Guias BAM } \\
\text { WS 0.7040-04 }\end{array}$ \\
\hline Cesto interno & $\begin{array}{c}\text { KTA 3201-2 } \\
\text { KTA } 3905\end{array}$ & $\begin{array}{c}\text { WS 1.4565-01 } \\
\text { WS 1.4462-01 } \\
\text { WS 1.4300-02 } \\
\text { WS 1.4306Bor-01 } \\
\text { WS Bor-Al-01 } \\
\end{array}$ & $\begin{array}{c}\text { DIN EN } \\
25817 \\
\text { DIN EN ISO } \\
13819\end{array}$ & $\begin{array}{c}\text { TRV } 006 \\
\text { DIN EN } 10204 \\
\text { WS }\end{array}$ \\
\hline Tampa primária & $\begin{array}{c}\text { IAEA-TS-R-1 } \\
\text { Recomendações BAM } \\
\text { KTA 3201-2 } \\
\text { Normas FKM } \\
\end{array}$ & WS 1.4313-02 & N/A & $\begin{array}{c}\text { TRV } 006 \\
\text { DIN EN } 10204 \\
\text { WS 1.4313-02 }\end{array}$ \\
\hline $\begin{array}{c}\text { Tampa } \\
\text { secundária }\end{array}$ & $\begin{array}{c}\text { IAEA-TS-R-1 } \\
\text { Recomendações BAM } \\
\text { KTA 3201-2 } \\
\text { Normas FKM } \\
\end{array}$ & WS 1.4313-02 & N/A & $\begin{array}{c}\text { TRV } 006 \\
\text { DIN EN } 10204 \\
\text { WS 1.4313-02 }\end{array}$ \\
\hline $\begin{array}{l}\text { Selo metálico } \\
\text { (alumínio) }\end{array}$ & Recomendações BAM & $\begin{array}{l}\text { WS 2.4969-01 } \\
\text { WS 1.4307-01 } \\
\text { WS 3.0255-01 } \\
\end{array}$ & N/A & $\begin{array}{c}\text { TRV } 006 \\
\text { DIN EN } 10204 \\
\text { WS } \\
\end{array}$ \\
\hline $\begin{array}{l}\text { Selo metálico } \\
\text { (prata) }\end{array}$ & Recomendações BAM & $\begin{array}{c}\text { WS 2.4969-01 } \\
\text { WS 1.4307-02 } \\
\text { WS Ag 99,99-01 }\end{array}$ & N/A & $\begin{array}{c}\text { TRV } 006 \\
\text { DIN EN } 10204 \\
\text { WS }\end{array}$ \\
\hline $\begin{array}{l}\text { Parafusos das } \\
\text { tampas }\end{array}$ & $\begin{array}{c}\text { IAEA-TS-R-1 } \\
\text { Recomendações BAM } \\
\text { VDI } 2230 \\
\end{array}$ & WS 1.4313-01 & N/A & $\begin{array}{c}\text { TRV } 006 \\
\text { DIN EN } 10204 \\
\text { WS 1.4313-01 } \\
\end{array}$ \\
\hline $\begin{array}{l}\text { Válvula de } \\
\text { pressão }\end{array}$ & IAEA-TS-R-1 & WS 1.4310-01 & $\begin{array}{c}\text { DIN EN } \\
25817\end{array}$ & $\begin{array}{c}\text { TRV } 006 \\
\text { DIN EN } 10204 \\
\text { WS 1.4310-01 }\end{array}$ \\
\hline $\begin{array}{l}\text { Placa de } \\
\text { proteção }\end{array}$ & Normas FKM & WS $1.0570-01$ & N/A & $\begin{array}{c}\text { TRV } 006 \\
\text { DIN EN } 10204 \\
\text { WS 1.0570-01 }\end{array}$ \\
\hline Munhões & $\begin{array}{c}\text { Recomendações BAM } \\
\text { KTA } 3905 \\
\text { Normas FKM } \\
\end{array}$ & WS 1.4313-04 & N/A & $\begin{array}{c}\text { TRV } 006 \\
\text { DIN EN } 10204 \\
\text { WS 1.4313-04 }\end{array}$ \\
\hline $\begin{array}{l}\text { Parafusos dos } \\
\text { apoios }\end{array}$ & $\begin{array}{c}\text { Recomendações BAM } \\
\text { KTA } 3905 \\
\text { VDI } 2230 \\
\end{array}$ & WS 1.4313-01 & N/A & $\begin{array}{c}\text { TRV } 006 \\
\text { DIN EN } 10204 \\
\text { WS 1.4313-01 } \\
\end{array}$ \\
\hline $\begin{array}{l}\text { Coberturas } \\
\text { absorvedoras }\end{array}$ & Normas GNB & $\begin{array}{l}\text { DIN EN } 10025 \\
\text { DIN EN } 10029 \\
\text { WB 52, WB } 54\end{array}$ & $\begin{array}{l}\text { DIN EN } \\
25817\end{array}$ & $\begin{array}{c}\text { TRV } 006 \\
\text { DIN EN } 10204 \\
\text { WB 52, WB } 54\end{array}$ \\
\hline $\begin{array}{l}\text { Barras e placas } \\
\text { moderadoras }\end{array}$ & IAEA-TS-R-1 & WS 1.PE-HD-01 & N/A & $\begin{array}{c}\text { TRV } 006 \\
\text { DIN EN } 10204 \\
\text { WS 1.PE-HD-01 }\end{array}$ \\
\hline
\end{tabular}

BAM - Bundesanstalt für Materialforschung und -prüfung - Instituto Federal de Investigação de Materiais e Ensaios; DIN - Deutsches Institut für Normung - Instituto de Normas Alemãs; FKM - Forschungskuratotium Maschinenbau - Corpo de Especialistas em Pesquisas de Engenharia Mecânica; KTA - Kerntechnischen Ausschusses - Comitê Técnico Nuclear; TRV - Technische Richtlinie für Verpackungen - Guia Técnico para Embalagens; VDI - Verein Deutscher Ingenieurs - Associação Alemã de Engenheiros; WS e WB - Normas de materiais produzidas pela empresa GNB; N/A - Não aplicável.

Fonte: Adaptado de Cumo et al., 2004 
8 APÊNDICES 


\section{APÊNDICE A \\ AJUSTE DAS CURVAS DAS ESPESSURAS}

As curvas foram ajustadas pelo software LAB Fit, por meio de regressão não linear, nas quais puderam ser estimados os valores para 16 e 32 elementos.

A.1.

Espessura da blindagem de gama para casco de chumbo

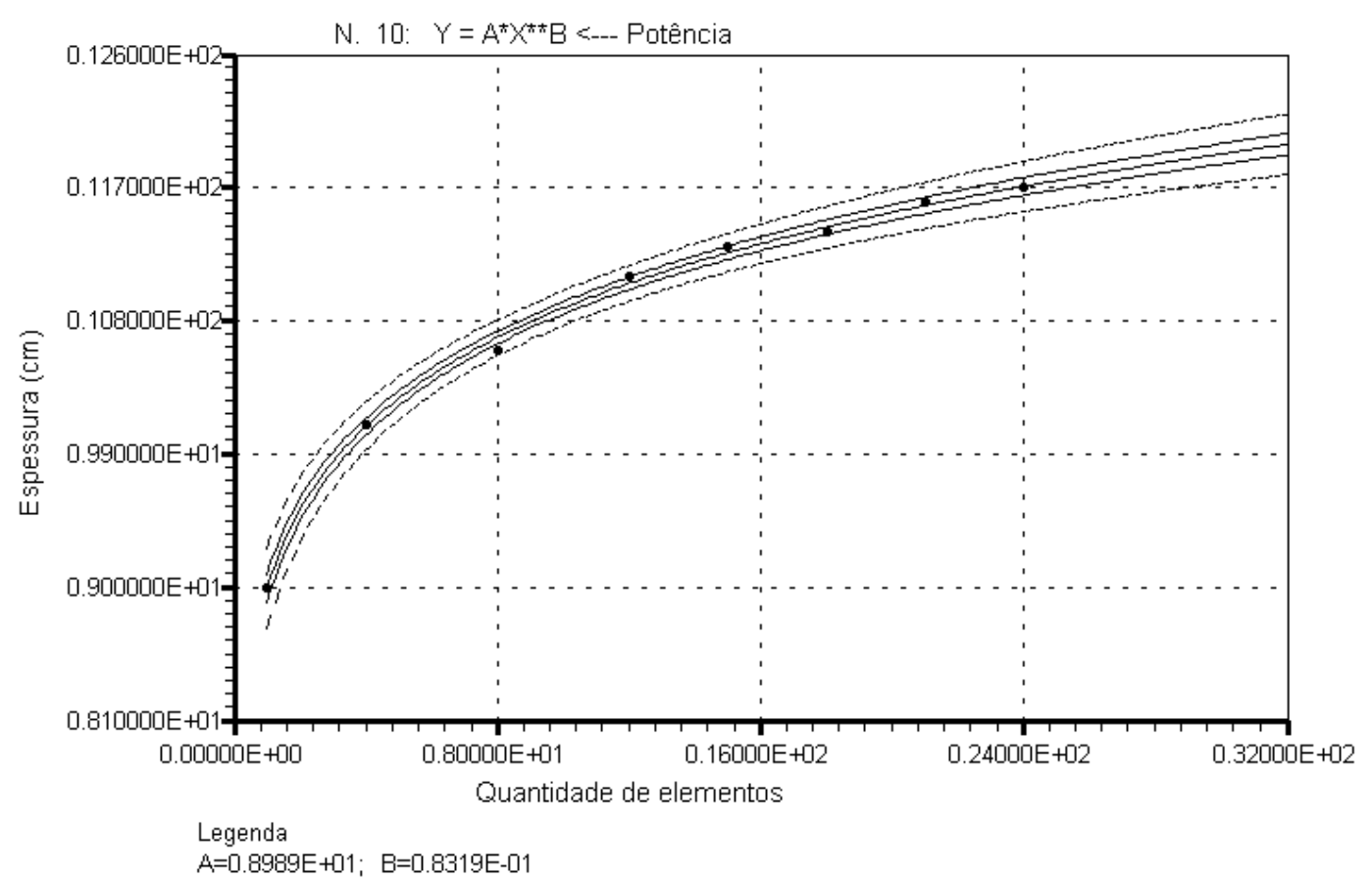

A.2.

Espessura da blindagem de neutrons para casco de chumbo

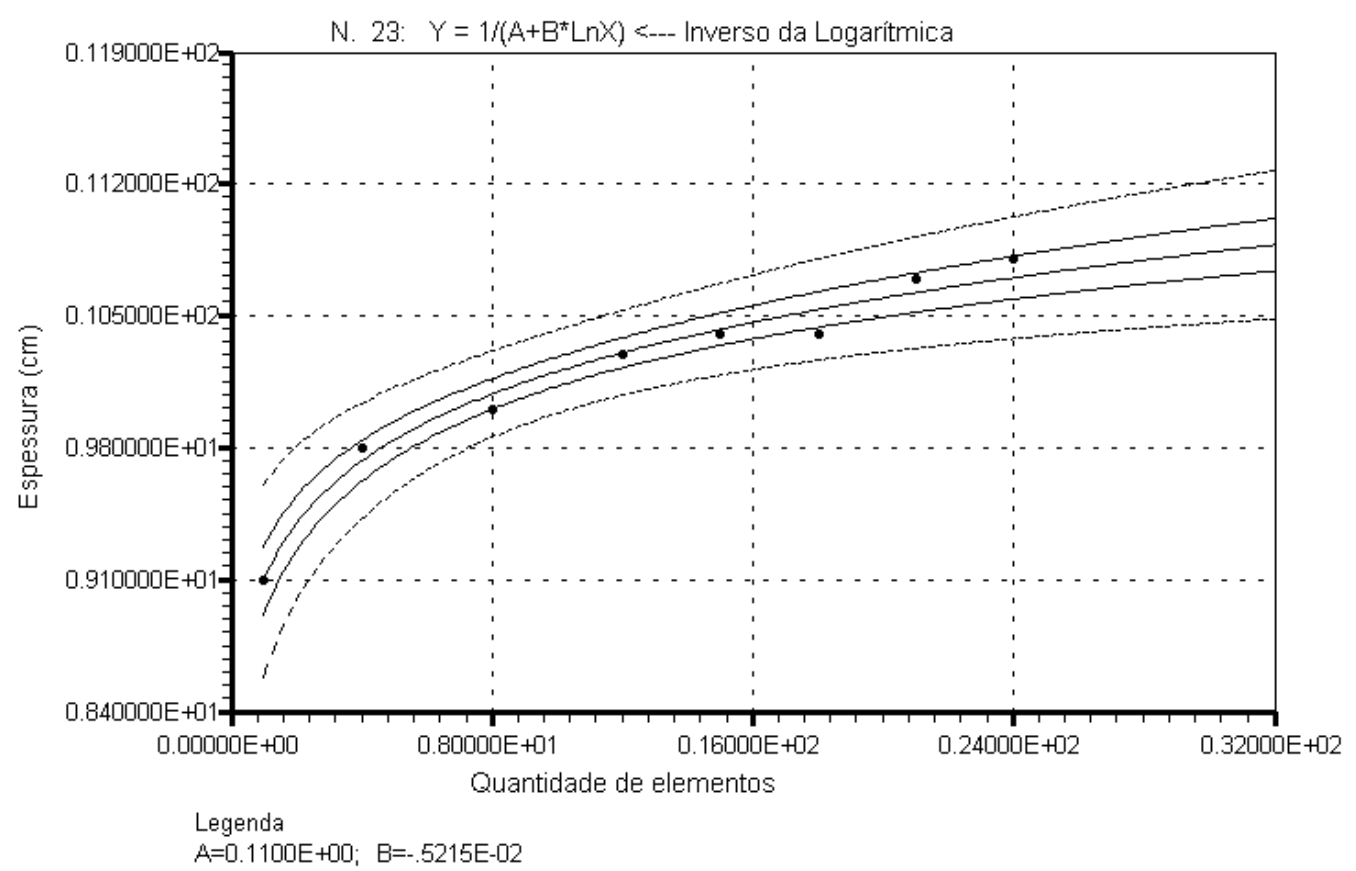


A.3

Espessura da blindagem de gama para casco de ferro

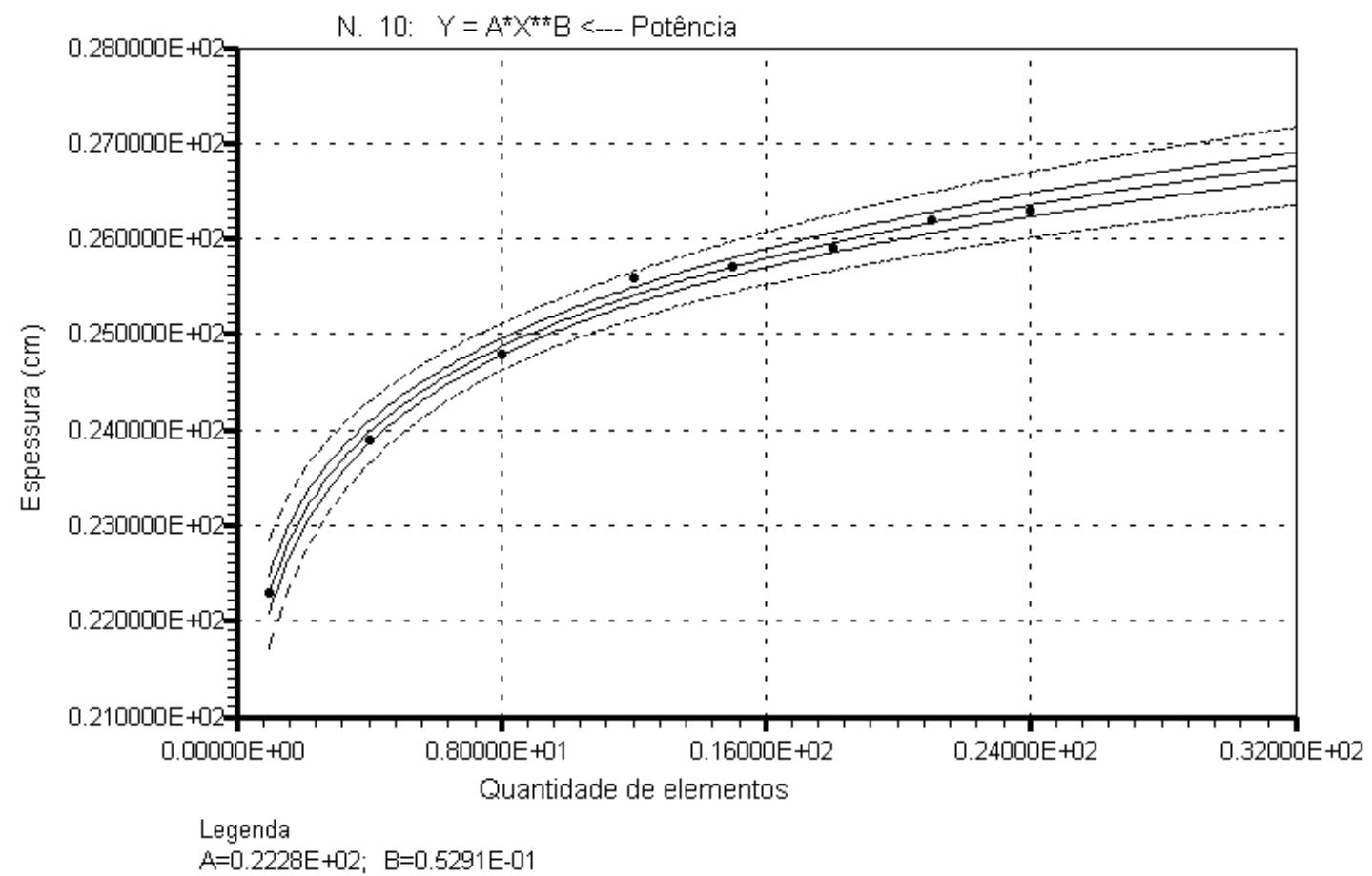

A. 4

Espessura da blindagem de neutrons para casco de ferro

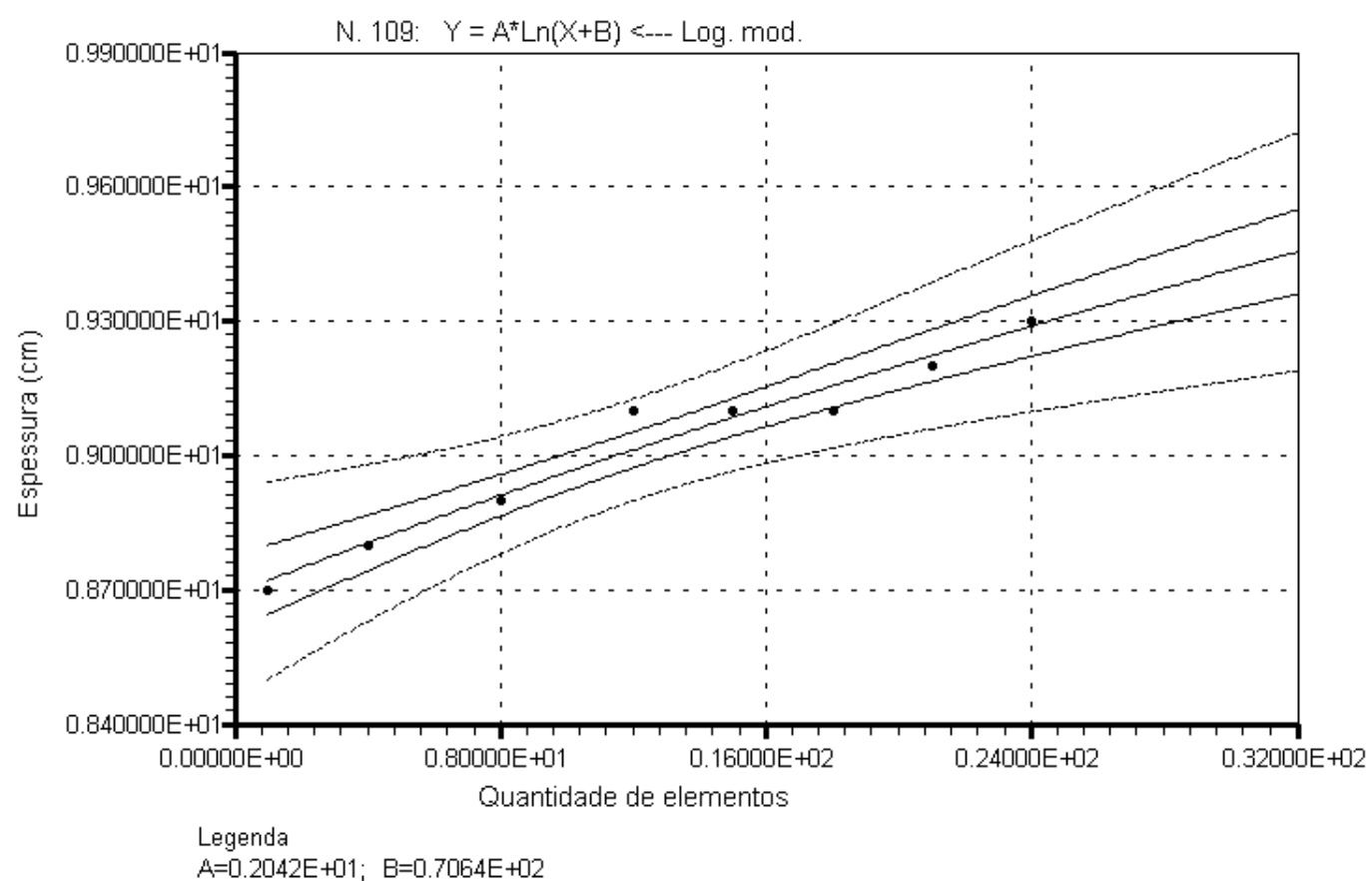




\section{A. 5}

Espessura da blindagem de gama para casco de urânio

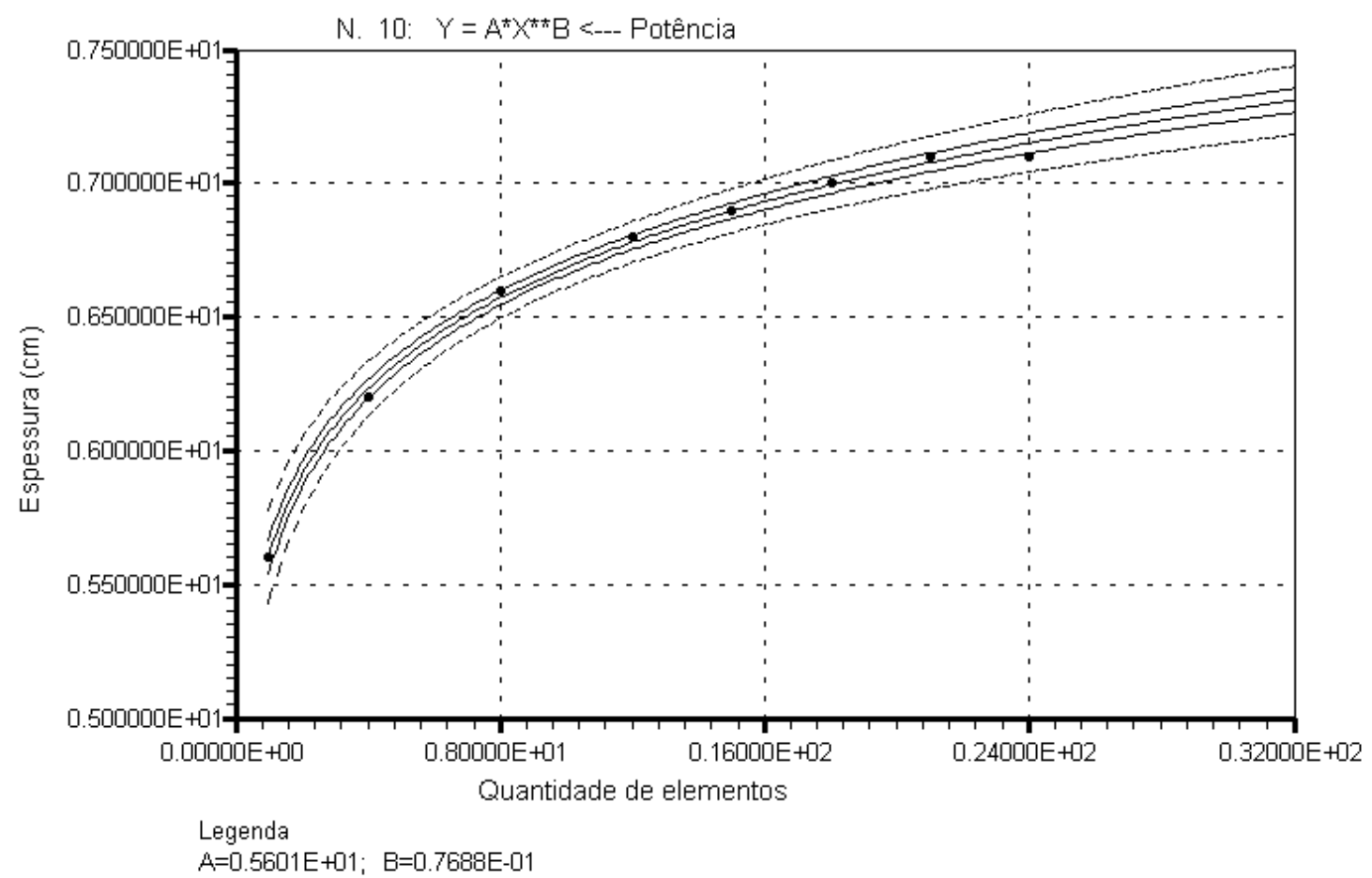

A. 6

Espessura da blindagem de neutrons para casco de urânio

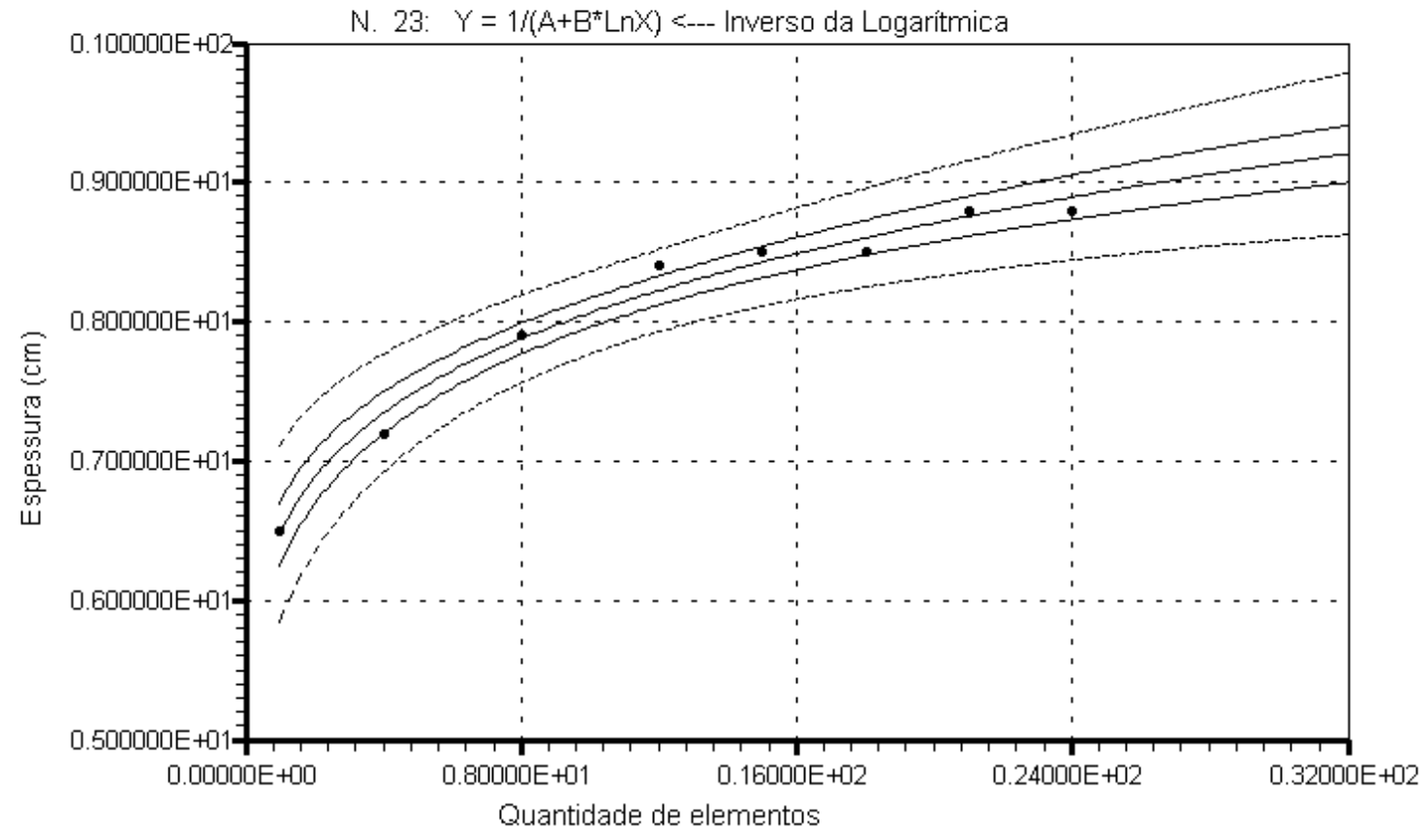

Legenda

$\mathrm{A}=[1.1545 \mathrm{E}+[\mathrm{D} ; \mathrm{B}=-.1323 \mathrm{E}-\mathrm{\square} 1$ 


\section{APÊNDICE B}

\section{ÁREAS, VOLUMES E MASSAS}

\begin{tabular}{|c|c|c|c|c|c|}
\hline Casco & $\begin{array}{c}\text { Área do cesto } \\
\left(\mathrm{cm}^{2}\right)\end{array}$ & $\begin{array}{c}\text { Massa do } \\
\text { elemento } \\
(\mathrm{kg})\end{array}$ & $\begin{array}{c}\text { Altura do } \\
\text { elemento } \\
(\mathrm{cm})\end{array}$ & $\begin{array}{c}\text { Volume do } \\
\text { cesto } \\
\left(\mathrm{cm}^{3}\right)\end{array}$ & $\begin{array}{c}\text { Massa do } \\
\text { cesto } \\
(\mathrm{kg})\end{array}$ \\
\hline C1 & 46,92 & 832,0 & 483,50 & 22685,8 & 178,5 \\
\hline C4 & 140,01 & 3328,0 & 483,50 & 90743,3 & 714,2 \\
\hline C8 & 279,77 & 6656,0 & 483,50 & 181486,6 & 1428,3 \\
\hline C12 & 360,88 & 9984,0 & 483,50 & 272229,8 & 2142,5 \\
\hline C15 & 465,70 & 12480,0 & 483,50 & 340287,3 & 2678,1 \\
\hline C16 & 465,45 & 13312,0 & 483,50 & 362973,1 & 2856,6 \\
\hline C18 & 604,96 & 14976,0 & 483,50 & 408344,8 & 3213,7 \\
\hline C21 & 604,96 & 17472,0 & 483,50 & 476402,2 & 3749,3 \\
\hline C24 & 698,05 & 19968,0 & 483,50 & 544459,7 & 4284,9 \\
\hline C32 & 883,73 & 26624,0 & 483,50 & 725946,2 & 5713,2 \\
\hline
\end{tabular}

C1 = casco com um elemento combustível; C4 = casco com 4 elementos combustíveis, etc.

\begin{tabular}{|c|c|c|c|c|c|c|c|}
\hline & \multirow{2}{*}{$\begin{array}{c}\text { Diâmetro } \\
\text { interno da } \\
\text { Cavidade }\end{array}$} & \multicolumn{3}{|c|}{ Volume do revestimento interno } & \multicolumn{3}{|c|}{$\begin{array}{c}\text { Massa do revestimento interno } \\
(\mathrm{kg})\end{array}$} \\
\cline { 3 - 8 } & $(\mathrm{cm})$ & $\mathrm{p} / \mathrm{Pb}$ & $\mathrm{p} / \mathrm{Fe}$ & $\mathrm{p} / \mathrm{U}$ & $\mathrm{p} / \mathrm{Pb}$ & $\mathrm{p} / \mathrm{Fe}$ & $\mathrm{p} / \mathrm{U}$ \\
\hline C1 & 33,85 & 227573,0 & 54954,6 & 107405,9 & 1791,0 & 432,5 & 845,3 \\
\hline C4 & 67,06 & 442279,4 & 110872,0 & 214005,9 & 3480,7 & 872,6 & 1684,2 \\
\hline C8 & 97,35 & 649588,5 & 164894,1 & 316973,4 & 5112,3 & 1297,7 & 2494,6 \\
\hline C12 & 118,00 & 797199,0 & 203375,7 & 390310,3 & 6273,9 & 1600,6 & 3071,7 \\
\hline C15 & 126,99 & 863051,9 & 220547,3 & 423032,8 & 6792,2 & 1735,7 & 3329,3 \\
\hline C16 & 133,42 & 910744,3 & 232984,8 & 446733,2 & 7167,6 & 1833,6 & 3515,8 \\
\hline C18 & 137,48 & 941112,3 & 240904,9 & 461825,0 & 7406,6 & 1895,9 & 3634,6 \\
\hline C21 & 137,48 & 941112,3 & 240904,9 & 461825,0 & 7406,6 & 1895,9 & 3634,6 \\
\hline C24 & 149,01 & 1028427,0 & 263679,7 & 505220,9 & 8093,7 & 2075,2 & 3976,1 \\
\hline C32 & 169,87 & 1190430,0 & 305944,9 & 585749,1 & 9368,7 & 2407,8 & 4609,8 \\
\hline
\end{tabular}

C1 = casco com um elemento combustível; C4 = casco com 4 elementos combustíveis, etc.

\begin{tabular}{|c|c|c|c|c|c|c|}
\hline \multirow{2}{*}{ Casco } & \multicolumn{4}{|c|}{$\begin{array}{c}\text { Volume da blindagem para raios gama } \\
\left(\mathrm{cm}^{3}\right)\end{array}$} & \multicolumn{3}{|c|}{ Massa da blindagem para raios gama } \\
& \multicolumn{3}{|c|}{$\mathrm{kg})$} \\
\cline { 2 - 7 } & $\mathrm{p} / \mathrm{Pb}$ & $\mathrm{p} / \mathrm{Fe}$ & $\mathrm{p} / \mathrm{U}$ & $\mathrm{p} / \mathrm{Pb}$ & $\mathrm{p} / \mathrm{Fe}$ & $\mathrm{p} / \mathrm{U}$ \\
\hline $\mathrm{C} 1$ & 750489,8 & 2070366,8 & 391774,71 & 8510,6 & 16293,8 & 7482,9 \\
\hline C4 & 1463545,3 & 3598921,8 & 798932,8 & 16596,6 & 28323,5 & 15259,6 \\
\hline C8 & 2154684,2 & 5044600,4 & 1224259,6 & 24434,1 & 39701,0 & 23383,4 \\
\hline C12 & 2721936,4 & 6132129,7 & 1534563,8 & 30866,8 & 48259,8 & 29310,2 \\
\hline C15 & 2982032,7 & 6595246,4 & 1681039,1 & 33816,3 & 51904,6 & 32107,8 \\
\hline C16 & 3161385,7 & 6915598,3 & 1769561,9 & 35850,1 & 54425,8 & 33798,6 \\
\hline C18 & 3256909,8 & 7130850,9 & 1854134,9 & 36933,4 & 56119,8 & 35414,0 \\
\hline C21 & 3320078,1 & 7239618,4 & 1882402,7 & 37649,7 & 56975,8 & 35953,9 \\
\hline C24 & 3633718,2 & 7815897,1 & 2049195,6 & 41206,4 & 61511,1 & 39139,6 \\
\hline C32 & 4351032,8 & 9023289,7 & 2428888,4 & 49340,7 & 71013,3 & 46391,8 \\
\hline
\end{tabular}

C1 = casco com um elemento combustível; C4 = casco com 4 elementos combustíveis, etc. 


\begin{tabular}{|c|c|c|c|c|c|c|}
\multirow{2}{*}{ Casco } & \multicolumn{4}{|c|}{$\begin{array}{c}\text { Volume do revestimento } \\
\text { intermediário }\left(\mathrm{cm}^{3}\right)\end{array}$} & \multicolumn{3}{c|}{ Massa do revestimento intermediário } \\
& $\mathrm{kgg})$ \\
\cline { 2 - 7 } & $\mathrm{p} / \mathrm{Pb}$ & $\mathrm{p} / \mathrm{Fe}$ & $\mathrm{p} / \mathrm{U}$ & $\mathrm{p} / \mathrm{Pb}$ & $\mathrm{p} / \mathrm{Fe}$ & $\mathrm{p} / \mathrm{U}$ \\
\hline C1 & 565388,1 & 146782,3 & 462637,3 & 4449,6 & 1155,2 & 3640,9 \\
\hline C4 & 907306,4 & 219655,7 & 782220,9 & 7140,5 & 1728,7 & 6156,1 \\
\hline C8 & 1226253,7 & 287867,9 & 1087510,0 & 9650,6 & 2265,5 & 8558,7 \\
\hline C12 & 1457461,5 & 336912,3 & 1303713,0 & 11470,2 & 2651,5 & 10260,2 \\
\hline C15 & 1560203,5 & 358208,6 & 1399994,0 & 12278,8 & 2819,1 & 11017,9 \\
\hline C16 & 1633446,9 & 373377,7 & 1468165,0 & 12855,2 & 2938,5 & 11554,5 \\
\hline C18 & 1678328,0 & 383244,8 & 1513694,0 & 13208,4 & 3016,1 & 11912,8 \\
\hline C21 & 1683875,2 & 384986,1 & 1516353,0 & 13252,1 & 3029,8 & 11933,7 \\
\hline C24 & 1815771,4 & 412297,5 & 1641664,0 & 14290,1 & 3244,8 & 12919,9 \\
\hline C32 & 2069735,8 & 464834,1 & 1877980,0 & 16288,8 & 3658,2 & 14779,7 \\
\hline
\end{tabular}

C1 = casco com um elemento combustível; C4 = casco com 4 elementos combustíveis, etc.

\begin{tabular}{|r|r|r|r|r|r|r|}
\hline \multirow{2}{*}{ Casco } & \multicolumn{4}{|c|}{ Volume da blindagem para nêutrons } & \multicolumn{3}{c|}{ Massa da blindagem para nêutrons } \\
& \multicolumn{3}{|c|}{$\left(\mathrm{cm}^{3}\right)$} & & \multicolumn{1}{c|}{ (kg) } & \\
\cline { 2 - 7 } & $\mathrm{p} / \mathrm{Pb}$ & $\mathrm{p} / \mathrm{Fe}$ & $\mathrm{p} / \mathrm{U}$ & $\mathrm{p} / \mathrm{Pb}$ & $\mathrm{p} / \mathrm{Fe}$ & $\mathrm{p} / \mathrm{U}$ \\
\hline C1 & 1279440,5 & 1461870,0 & 733925,6 & 1228,3 & 1403,4 & 704,6 \\
\hline C4 & 2083383,5 & 2146632,0 & 1292554,0 & 2000,0 & 2060,8 & 1240,8 \\
\hline C8 & 2786295,4 & 2798638,0 & 1923224,0 & 2674,8 & 2686,7 & 1846,3 \\
\hline C12 & 3367022,4 & 3325973,0 & 2425086,0 & 3232,3 & 3192,9 & 2328,1 \\
\hline C15 & 3621816,4 & 3525308,0 & 2623518,0 & 3476,9 & 3384,3 & 2518,6 \\
\hline C16 & 3777991,9 & 3667233,0 & 2741359,0 & 3626,9 & 3520,5 & 2631,7 \\
\hline C18 & 3873626,3 & 3759542,0 & 2820968,0 & 3718,7 & 3609,2 & 2708,1 \\
\hline C21 & 4006943,8 & 3820188,0 & 2932612,0 & 3846,7 & 3667,4 & 2815,3 \\
\hline C24 & 4339601,9 & 4125646,0 & 3155980,0 & 4166,0 & 3960,6 & 3029,7 \\
\hline C32 & 5146101,3 & 4680506,0 & 3753417,0 & 4940,3 & 4493,3 & 3603,3 \\
\hline
\end{tabular}

C1 = casco com um elemento combustível; C4 = casco com 4 elementos combustíveis, etc.

\begin{tabular}{|c|r|r|r|r|r|r|}
\hline \multirow{2}{*}{ Casco } & \multicolumn{3}{|c|}{ Volume do revestimento externo } & \multicolumn{3}{c|}{ Massa do revestimento externo } \\
& \multicolumn{2}{|c|}{$\left(\mathrm{cm}^{3}\right)$} & & & \multicolumn{1}{c|}{} \\
& $\mathrm{p} / \mathrm{Pb}$ & $\mathrm{p} / \mathrm{Fe}$ & $\mathrm{p} / \mathrm{U}$ & $\mathrm{p} / \mathrm{Pb}$ & $\mathrm{p} / \mathrm{Fe}$ & $\mathrm{p} / \mathrm{U}$ \\
\hline C1 & 313018,6 & 365801,5 & 247453,9 & 2463,5 & 2878,7 & 1947,5 \\
\hline C4 & 458018,9 & 515339,9 & 380711,3 & 3604,6 & 4055,7 & 2996,2 \\
\hline C8 & 588991,5 & 654088,5 & 509063,8 & 4635,4 & 5147,7 & 4006,3 \\
\hline C12 & 685512,4 & 755149,1 & 600156,9 & 5394,9 & 5943,0 & 4723,2 \\
\hline C15 & 728054,7 & 798027,8 & 639738,4 & 5729,8 & 6280,5 & 5034,7 \\
\hline C16 & 757574,9 & 828544,4 & 666877,7 & 5962,1 & 6520,6 & 5248,3 \\
\hline C18 & 775642,8 & 848390,1 & 685214,0 & 6104,3 & 6676,8 & 5392,6 \\
\hline C21 & 781312,5 & 853105,0 & 689513,5 & 6148,9 & 6713,9 & 5426,5 \\
\hline C24 & 835625,5 & 909213,6 & 739213,6 & 6576,4 & 7155,5 & 5817,6 \\
\hline C32 & 943973,4 & 1016035,0 & 838081,8 & 7429,1 & 7996,2 & 6595,7 \\
\hline
\end{tabular}

C1 = casco com um elemento combustível; C4 = casco com 4 elementos combustíveis, etc. 


\begin{tabular}{|c|c|c|c|c|c|c|}
\hline \multirow{2}{*}{ Casco } & \multicolumn{3}{|c|}{$\begin{array}{c}\text { Massa do casco } \\
\text { (kg) }\end{array}$} & \multicolumn{3}{c|}{ Massa total do casco com elemento } \\
& $\mathrm{kg})$ & \\
\cline { 2 - 7 } & $\mathrm{p} / \mathrm{Pb}$ & $\mathrm{p} / \mathrm{Fe}$ & $\mathrm{p} / \mathrm{U}$ & $\mathrm{p} / \mathrm{Pb}$ & $\mathrm{p} / \mathrm{Fe}$ & $\mathrm{p} / \mathrm{U}$ \\
\hline C1 & 18621,4 & 22342,3 & 14799,7 & 19453,0 & 23174,0 & 15632,0 \\
\hline C4 & 33536,6 & 37755,4 & 28051,1 & 36865,0 & 41083,0 & 31379,0 \\
\hline C8 & 47935,5 & 52526,9 & 41717,6 & 54592,0 & 59183,0 & 48374,0 \\
\hline C12 & 59380,7 & 63790,3 & 51835,9 & 69365,0 & 73774,0 & 61820,0 \\
\hline C15 & 64772,1 & 68802,2 & 56686,4 & 77252,0 & 81282,0 & 69166,0 \\
\hline C16 & 68318,5 & 72095,6 & 59605,5 & 81630,0 & 85408,0 & 72918,0 \\
\hline C18 & 70585,0 & 74531,5 & 62275,7 & 85561,0 & 89508,0 & 77252,0 \\
\hline C21 & 72053,2 & 76032,2 & 63513,2 & 89525,0 & 93504,0 & 80985,0 \\
\hline C24 & 78617,5 & 82232,1 & 69167,8 & 98585,0 & 102200,0 & 89136,0 \\
\hline C32 & 93080,7 & 95282,0 & 81693,5 & 119705,0 & 121906,0 & 108317,0 \\
\hline
\end{tabular}

C1 = casco com um elemento combustível; C4 = casco com 4 elementos combustíveis, etc. 


\section{APÊNDICE C \\ UTILIZAÇÃO DO AHP PARA TOMADA DE DECISÃO QUANTO A ESCOLHA DA QUANTIDADE DE ELEMENTOS CNQ NO CASCO}

\section{C.1. - Geral}

O método pode ser resumido como:

- Identificação das alternativas e atributos significantes.

- Os responsáveis pela decisão indicam a significância relativa entre os atributos

- Similarmente, para cada atributo, e para cada par de alternativas os responsáveis pela decisão especificam suas preferências.

- As comparações entre os atributos e as alternativas são registradas em matrizes na forma de frações entre 1/9 e 9. Cada matriz é avaliada pelo seu autovalor para verificar a coerência dos julgamentos. Este procedimento gera uma "razão de coerência" que será igual a 1 se todos os julgamentos forem coerentes entre si.

- Calculam-se valores globais de preferência para cada alternativa.

a) Para os cascos, em geral, baseando nas comparações entre as alternativas consideradas significantes, elabora-se a matriz seguinte:

\begin{tabular}{l|ccc}
\hline \multirow{2}{*}{ Parâmetro } & \multicolumn{3}{|c}{ Proporção } \\
\cline { 2 - 4 } & Massa total & $\begin{array}{c}\text { Quantidade de } \\
\text { combustível }\end{array}$ & Dimensão menor \\
\hline Massa total & $1 / 1$ & $1 / 3$ & $1 / 9$ \\
Qte combustível & $3 / 1$ & $1 / 1$ & $1 / 6$ \\
Dimensão menor & $9 / 1$ & $6 / 1$ & $1 / 1$ \\
\hline
\end{tabular}

$\mathrm{Ou}$,

$$
\left|\begin{array}{ccc}
1 & 0,333 & 0,111 \\
3 & 1 & 0,167 \\
9 & 6 & 1
\end{array}\right|
$$

b) Multiplicando esta última matriz por ela mesma:

$\left|\begin{array}{lll}1,0000 & 0,3333 & 0,1111 \\ 3,0000 & 1,0000 & 0,1667 \\ 9,0000 & 6,0000 & 1,0000\end{array}\right| \times\left|\begin{array}{rrr}1,0000 & 0,3333 & 0,1111 \\ 3,0000 & 1,0000 & 0,1667 \\ 9,0000 & 6,0000 & 1,0000\end{array}\right|=\left|\begin{array}{rrr}3,0000 & 1,3333 & 0,2778 \\ 7,5000 & 3,0000 & 0,6667 \\ 36,0000 & 15,000 & 3,0000\end{array}\right|$

c) Somando os elementos das linhas da matriz resultante: 


$$
\text { Soma }=\left|\begin{array}{r}
4,6111 \\
11,1667 \\
54,0000
\end{array}\right|
$$

d) Dividindo-se os valores de cada linha pela soma, tem-se uma primeira estimativa:

$$
\begin{aligned}
& 0,0661 \\
& 0,1600 \\
& 0,7739
\end{aligned}
$$

e) Multiplicando a matriz resultado por ela mesma,

$\left|\begin{array}{rrr}3,0000 & 1,3333 & 0,2778 \\ 7,5000 & 3,0000 & 0,6667 \\ 36,0000 & 15,000 & 3,0000\end{array}\right| \times\left|\begin{array}{rrr}3,0000 & 1,3333 & 0,2778 \\ 7,5000 & 3,0000 & 0,6667 \\ 36,0000 & 15,000 & 3,0000\end{array}\right|=\left|\begin{array}{rrr}29,0000 & 12,1667 & 2,5556 \\ 69,0000 & 29,0000 & 6,0833 \\ 328,5000 & 138,0000 & 29,000\end{array}\right|$

f) Somando as linhas da nova matriz resultante:

$$
\text { Soma }=\left|\begin{array}{r}
43,7222 \\
104,0833 \\
495,5000
\end{array}\right|
$$

g) Dividindo-se os valores de cada linha pela soma, tem-se uma segunda estimativa:

$$
\left|\begin{array}{l}
0,0680 \\
0,1618 \\
0,7702
\end{array}\right|
$$

h) Comparando as estimativas resultantes com os anteriores verifica-se que o processo está convergindo. Quando as comparações forem iguais, esses valores serão utilizados. As diferenças entre os resultados da primeira e segunda estimativa é:

$$
\begin{array}{r}
-0,0019 \\
-0,0018 \\
0,0036
\end{array}
$$

i) Multiplicando a nova matriz resultado por ela mesma, a fim de se obter uma nova estimativa,

\begin{tabular}{|rrr}
29,0000 & 12,1667 & 2,5556 \\
69,0000 & 29,0000 & 6,0833 \\
328,5000 & 138,0000 & 29,0000
\end{tabular}$|\times| \begin{array}{rrr}29,0000 & 12,1667 & 2,5556 \\
69,0000 & 29,0000 & 6,0833 \\
328,5000 & 138,0000 & 29,0000\end{array}|=|$\begin{tabular}{rrr|}
2520,0000 & 1058,3333 & 222,2361 \\
6000,3750 & 2520,0000 & 529,1667 \\
28575,000 & 12000,750 & 2520,000
\end{tabular} \mid


j) Somando as linhas da nova matriz resultante:

$$
\text { Soma }=\begin{array}{r}
3800,5694 \\
9049,5417 \\
43095,7500
\end{array} \mid
$$

k) Dividindo-se os valores de cada linha pela soma, tem-se uma segunda estimativa:

$$
\begin{aligned}
& 0,0679 \\
& 0,1618 \\
& 0,7703
\end{aligned} \mid
$$

l) As diferenças entre os resultados da primeira e segunda estimativa é:

$$
\begin{array}{r}
0,0001 \\
0,0000 \\
-0,0001
\end{array}
$$

A convergência foi realizada e será utilizada a segunda estimativa.

Quanto à comparação entre um atributo específico, para os diferentes tipos de casco, optou-se pelas seguintes condições, como sendo as melhores:

- Menor massa total do casco.

- Maior quantidade de combustível armazenado.

- Menores dimensões externas.

\section{C.2 - Casco de Ferro}

As massas adotadas para os cascos de ferro foram:

Massa do casco com 16 elementos: $m_{\mathrm{C} 16}=85.408 \mathrm{~kg}$

Massa do casco com 21 elementos: $m_{\mathrm{C} 21}=93.504 \mathrm{~kg}$

Massa do casco com 24 elementos: $m_{\mathrm{C} 24}=102.200 \mathrm{~kg}$

Massa do casco com 32 elementos: $m_{\mathrm{C} 32}=121.906 \mathrm{~kg}$

a) Na comparação entre as massas, para o casco de ferro, tem-se:

\begin{tabular}{c|cccc}
\hline Massa total & C16 & C21 & C24 & C32 \\
\hline C16 & 1,0000 & 1,1095 & 1,1966 & 1,4273 \\
C21 & 0,9130 & 1,0000 & 1,0930 & 1,3375 \\
C24 & 0,8356 & 0,9149 & 1,0000 & 1,1928 \\
C32 & 0,7006 & 0,7670 & 0,8384 & 1,0000 \\
\hline
\end{tabular}

b) Multiplicando essa matriz por ela mesma: 


$\left|\begin{array}{llll}1,0000 & 1,1095 & 1,1966 & 1,4273 \\ 0,9130 & 1,0000 & 1,0930 & 1,3375 \\ 0,8356 & 0,9149 & 1,0000 & 1,193 \\ 0,7006 & 0,7670 & 0,8384 & 1,0000\end{array}\right| \times\left|\begin{array}{llll}1,0000 & 1,1095 & 1,1966 & 1,4273 \\ 0,9130 & 1,0000 & 1,0930 & 1,3375 \\ 0,8356 & 0,9149 & 1,0000 & 1,1928 \\ 0,7006 & 0,7670 & 0,8384 & 1,0000\end{array}\right|=\left|\begin{array}{llll}4,0000 & 4,3792 & 4,7865 & 5,7094 \\ 3,6536 & 4,0000 & 4,3720 & 5,2150 \\ 3,3427 & 3,6596 & 4,0000 & 4,7713 \\ 2,8024 & 3,0681 & 3,3534 & 4,0000\end{array}\right|$

c) Somando os elementos das linhas da matriz resultado:

$$
\text { Soma }=\quad \begin{aligned}
& 18,8750 \\
& 17,2406 \\
& 15,7737 \\
& 13,2239
\end{aligned} \mid
$$

d) Dividindo-se os valores de cada linha pela soma, tem-se uma primeira estimativa:

$$
\begin{aligned}
& 0,2899 \\
& 0,2648 \\
& 0,2422 \\
& 0,2031
\end{aligned}
$$

e) Multiplicando a matriz resultado por ela mesma,

$\left|\begin{array}{|llll}4,0000 & 4,3792 & 4,7865 & 5,7094 \\ 3,6536 & 4,0000 & 4,3720 & 5,2150 \\ 3,3427 & 3,6596 & 4,0000 & 4,7713 \\ 2,8024 & 3,0681 & 3,3534 & 4,0000\end{array}\right| \times\left|\begin{array}{rrrrrr}4,0000 & 4,3792 & 4,7865 & 5,7094 \\ 3,6536 & 4,0000 & 4,3720 & 5,2150 \\ 3,3427 & 3,6596 & 4,0000 & 4,7713 \\ 2,8024 & 3,0681 & 3,3534 & 4,0000\end{array}\right|=\left|\begin{array}{ccccc}64,0000 & 70,0671 & 76,5834 & 91,3500 \\ 58,4582 & 64,0000 & 69,9520 & 83,4400 \\ 53,4842 & 58,5544 & 64,0000 & 76,3403 \\ 44,8385 & 49,0892 & 53,6545 & 64,0000\end{array}\right|$

f) Somando as linhas da nova matriz resultante:

$$
\text { Soma }=1041,8118
$$

g) Dividindo-se os valores de cada linha pela soma, tem-se uma segunda estimativa:

$$
\begin{aligned}
& 0,2899 \\
& 0,2648 \\
& 0,2422 \\
& 0,2031
\end{aligned}
$$

h) As diferenças entre os resultados da primeira e segunda estimativa é:

$\begin{array}{r}0,00 \\ 0,00 \\ 0,00 \\ 0,00 \\ \hline\end{array}$

Portanto, o processo convergiu e segue a segunda estimativa. 
i) Na comparação entre as quantidades de combustíveis, tem-se:

\begin{tabular}{c|c}
\hline $\begin{array}{c}\text { Quantidade de combustível } \\
\text { por casco }\end{array}$ \\
\hline C16 & 16 \\
C21 & 21 \\
C24 & 24 \\
C32 & 32 \\
\hline
\end{tabular}

j) Somando a quantidade de elementos, tem-se:

$$
\text { Soma }=\begin{array}{r}
16 \\
21 \\
24 \\
32
\end{array} \mid
$$

k) Dividindo os valores de cada linha pela soma, tem-se a estimativa:

\begin{tabular}{l}
0,1720 \\
0,2258 \\
0,2581 \\
0,3441 \\
\hline
\end{tabular}

Os diâmetros externos adotados para os cascos de ferro foram:

Diâmetro externo do casco com 16 elementos: $d_{\mathrm{C} 16}=2,11 \mathrm{~m}$

Diâmetro externo do casco com 21 elementos: $d_{\mathrm{C} 21}=2,16 \mathrm{~m}$

Diâmetro externo do casco com 24 elementos: $d_{\mathrm{C} 24}=2,28 \mathrm{~m}$

Diâmetro externo do casco com 32 elementos: $d_{\mathrm{C} 32}=2,50 \mathrm{~m}$

l) Na comparação entre as dimensões dos cascos, tem-se:

\begin{tabular}{c|cccc}
\hline Dimensões & C16 & C21 & C24 & C32 \\
\hline C16 & 1,0000 & 1,0237 & 1,0806 & 1,1848 \\
C21 & 0,9769 & 1,0000 & 1,0556 & 1,1574 \\
C24 & 0,9254 & 0,9474 & 1,0000 & 1,0965 \\
C32 & 0,8440 & 0,8640 & 0,9120 & 1,0000 \\
\hline
\end{tabular}

m) Multiplicando essa matriz por ela mesma:

\begin{tabular}{|llll}
1,0000 & 1,0237 & 1,0806 & 1,1848 \\
0,9769 & 1,0000 & 1,0556 & 1,1574 \\
0,9254 & 0,9474 & 1,0000 & 1,0965 \\
0,8440 & 0,8640 & 0,9120 & 1,0000
\end{tabular}$|\times| \begin{array}{llllll}1,0000 & 1,0237 & 1,0806 & 1,1848 \\
0,9769 & 1,0000 & 1,0556 & 1,1574 \\
0,9254 & 0,9474 & 1,0000 & 1,0965 \\
0,8440 & 0,8640 & 0,9120 & 1,0000\end{array}|=| \begin{array}{rrrrr}4,0000 & 4,0948 & 4,3223 & 4,7393 \\
3,9074 & 4,0000 & 4,2222 & 4,6296 \\
3,7018 & 3,7895 & 4,0000 & 4,3859 \\
3,3760 & 3,4560 & 3,6480 & 4,0000\end{array} \mid$


n) Somando os elementos das linhas da matriz resultado:

$$
\text { Soma }=\quad \begin{aligned}
& 17,1564 \\
& 16,7593 \\
& 15,8772 \\
& 14,4800
\end{aligned} \mid
$$

o) Dividindo-se os valores de cada linha pela soma, tem-se uma primeira estimativa:

p) Multiplicando a matriz resultado por ela mesma,

$\left|\begin{array}{|cccc}4,0000 & 4,0948 & 4,3223 & 4,7393 \\ 3,9074 & 4,0000 & 4,2222 & 4,6296 \\ 3,7018 & 3,7895 & 4,0000 & 4,3859 \\ 3,3760 & 3,4560 & 3,6480 & 4,0000\end{array}\right| \times\left|\begin{array}{lllll}4,0000 & 4,0948 & 4,3223 & 4,7393 \\ 3,9074 & 4,0000 & 4,2222 & 4,6296 \\ 3,7018 & 3,7895 & 4,0000 & 4,3859 \\ 3,3760 & 3,4560 & 3,6480 & 4,0000\end{array}\right|=\left|\begin{array}{lllll|}64,0000 & 65,5166 & 69,1564 & 75,8294 \\ 62,5185 & 64,0000 & 67,5555 & 74,0741 \\ 59,2281 & 60,6316 & 64,0000 & 70,1754 \\ 54,0160 & 55,2960 & 58,3680 & 64,0000\end{array}\right|$

q) Somando as linhas da nova matriz resultante:

$$
\begin{array}{r|r}
274,5024 \\
268,1481 \\
254,0351 \\
231,6800
\end{array}
$$

r) Dividindo-se os valores de cada linha pela soma, tem-se uma segunda estimativa:

$$
\begin{aligned}
& 0,2669 \\
& 0,2608 \\
& 0,2470 \\
& 0,2253
\end{aligned}
$$

s) As diferenças entre os resultados da primeira e segunda estimativa são:

$\begin{array}{r}0,00 \\ 0,00 \\ 0,00 \\ 0,00 \\ \hline\end{array}$

Portanto, o processo convergiu e será utilizada a segunda estimativa.

t) Ordenando todas as estimativas resultantes, têm-se as comparações iniciais:

\begin{tabular}{|l|l|l|}
\hline 0,0679 & 0,1618 & 0,7703 \\
\hline
\end{tabular}


u) Estimativa da comparação da massa, quantidade de combustível e dimensões,

\begin{tabular}{l|c|c|c|c|c}
\hline \multicolumn{2}{c|}{} & \multicolumn{2}{c|}{$\begin{array}{c}\text { Quantidade de combustível } \\
\text { nos cascos }\end{array}$} & \multicolumn{2}{c}{ Dimensões } \\
\hline C16 & 0,2899 & C16 & 0,1720 & C16 & 0,2669 \\
C21 & 0,2648 & C21 & 0,2258 & C21 & 0,2608 \\
C24 & 0,2422 & C24 & 0,2581 & C24 & 0,2470 \\
C32 & 0,2031 & C32 & 0,3441 & C32 & 0,2253 \\
\hline
\end{tabular}

v) Multiplicando-se as novas matrizes:

$\left|\begin{array}{rrr}0,2899 & 0,1720 & 0,2669 \\ 0,2648 & 0,2258 & 0,2608 \\ 0,2422 & 0,2581 & 0,2470 \\ 0,2031 & 0,3441 & 0,2253\end{array}\right| \quad X \quad\left|\begin{array}{l}0,0679 \\ 0,1618 \\ 0,7703\end{array}\right|$

x) Resulta em:

\begin{tabular}{l|l|l}
\hline C16 & 0,2531 & \\
C21 & 0,2554 & $\rightarrow$ Maior valor, melhor opção \\
C24 & 0,2485 & \\
C32 & 0,2430 & \\
\hline
\end{tabular}

\section{C.3 - Casco de Chumbo}

As massas adotadas para os cascos de chumbo foram:

Massa do casco com 16 elementos: $m_{\mathrm{C} 16}=81.630 \mathrm{~kg}$

Massa do casco com 21 elementos: $m_{\mathrm{C} 21}=89.525 \mathrm{~kg}$

Massa do casco com 24 elementos: $m_{\mathrm{C} 24}=98.585 \mathrm{~kg}$

Massa do casco com 32 elementos: $m_{\mathrm{C} 32}=119.705 \mathrm{~kg}$

a) Na comparação entre as massas, para o casco de chumbo, tem-se:

\begin{tabular}{c|cccc}
\hline Massa total & C16 & C21 & C24 & C32 \\
\hline C16 & 1,0000 & 1,0970 & 1,2077 & 1,4664 \\
C21 & 0,9120 & 1,0000 & 1,1012 & 1,3371 \\
C24 & 0,8280 & 0,9081 & 1,0000 & 1,2142 \\
C32 & 0,6819 & 0,7478 & 0,8236 & 1,0000 \\
\hline
\end{tabular}

b) Realizando o processo análogo ao realizado para o casco de ferro, chega-se à estimativa:

$$
\begin{aligned}
& 0,2922 \\
& 0,2665 \\
& 0,2420 \\
& 0,1993
\end{aligned}
$$


c) Na comparação entre as quantidades de combustíveis, utiliza-se a mesma sistemática do casco de ferro, com os mesmos valores, obtendo-se a seguinte estimativa:

\begin{tabular}{l}
0,1720 \\
0,2258 \\
0,2581 \\
0,3441 \\
\hline
\end{tabular}

Os diâmetros externos adotados para os cascos de chumbo foram:

Diâmetro externo do casco com 16 elementos: $d_{\mathrm{C} 16}=1,99 \mathrm{~m}$

Diâmetro externo do casco com 21 elementos: $d_{\mathrm{C} 21}=2,04 \mathrm{~m}$

Diâmetro externo do casco com 24 elementos: $d_{\mathrm{C} 24}=2,16 \mathrm{~m}$

Diâmetro externo do casco com 32 elementos: $d_{\mathrm{C} 32}=2,38 \mathrm{~m}$

d) Na comparação entre as dimensões dos cascos, tem-se:

\begin{tabular}{c|cccc}
\hline Dimensões & C16 & C21 & C24 & C32 \\
\hline C16 & 1,0000 & 1,0255 & 1,0855 & 1,2006 \\
C21 & 0,9752 & 1,0000 & 1,0586 & 1,1708 \\
C24 & 0,9212 & 0,9446 & 1,0000 & 1,1060 \\
C32 & 0,8329 & 0,8541 & 0,9041 & 1,0000 \\
\hline
\end{tabular}

e) Analogamente ao casco de ferro, chega-se à:estimativa:

$\begin{array}{r}0,2682 \\ 0,2615 \\ 0,2470 \\ 0,2233 \\ \hline\end{array}$

f) Ordenando todas as estimativas resultantes, têm-se as comparações iniciais:

\begin{tabular}{l|c|c}
\hline 0,0679 & 0,1618 & 0,7703 \\
\hline
\end{tabular}

g) Estimativa da comparação da massa, quantidade de combustível e dimensões,

\begin{tabular}{l|l|l|l|l|l}
\hline \multicolumn{2}{c|}{} & \multicolumn{2}{c|}{$\begin{array}{c}\text { Quantidade de combustível } \\
\text { nos cascos }\end{array}$} & \multicolumn{2}{c}{ Dimensões } \\
\hline C16 & 0,2922 & C16 & 0,1720 & C16 & 0,2682 \\
C21 & 0,2665 & C21 & 0,2258 & C21 & 0,2615 \\
C24 & 0,2420 & C24 & 0,2581 & C24 & 0,2470 \\
C32 & 0,1993 & C32 & 0,3441 & C32 & 0,2233 \\
\hline
\end{tabular}

h) Multiplicando-se as novas matrizes: 


$\left|\begin{array}{rrr}0,2922 & 0,1720 & 0,2682 \\ 0,2665 & 0,2258 & 0,2615 \\ 0,2420 & 0,2581 & 0,2470 \\ 0,1993 & 0,3441 & 0,2233\end{array}\right| \quad X \quad\left|\begin{array}{l}0,0679 \\ 0,1618 \\ 0,7703\end{array}\right|$

i) Resulta em:

\begin{tabular}{l|l|l}
\hline C16 & 0,2542 & \\
C21 & 0,2561 & $\Rightarrow$ Maior valor, melhor opção \\
C24 & 0,2485 & \\
C32 & 0,2412 & \\
\hline
\end{tabular}

\section{C.4 - Casco de Urânio Exaurido}

As massas adotadas para os cascos de urânio exaurido foram:

Massa do casco com 16 elementos: $m_{\mathrm{C} 16}=72.918 \mathrm{~kg}$

Massa do casco com 21 elementos: $m_{\mathrm{C} 21}=80.985 \mathrm{~kg}$

Massa do casco com 24 elementos: $m_{\mathrm{C} 24}=89.136 \mathrm{~kg}$

Massa do casco com 32 elementos: $m_{\mathrm{C} 32}=108.317 \mathrm{~kg}$

a) Na comparação entre as massas, para o casco de urânio, tem-se:

\begin{tabular}{c|cccc}
\hline Massa total & C16 & C21 & C24 & C32 \\
\hline C16 & 1,0000 & 1,1111 & 1,2224 & 1,4855 \\
C21 & 0,9000 & 1,0000 & 1,1006 & 1,3375 \\
C24 & 0,8180 & 0,9086 & 1,0000 & 1,2152 \\
C32 & 0,6732 & 0,7477 & 0,8229 & 1,0000 \\
\hline
\end{tabular}

b) Realizando o processo análogo aos realizados para os cascos de ferro e chumbo, chega-se à estimativa seguinte:

$$
\begin{aligned}
& 0,2948 \\
& 0,2655 \\
& 0,2412 \\
& 0,1985
\end{aligned}
$$

c) Na comparação entre as quantidades de combustíveis, utiliza-se a mesma sistemática do casco de ferro e de chumbo, com os mesmos valores, obtendo-se a estimativa seguinte:

\begin{tabular}{l}
0,1720 \\
0,2258 \\
0,2581 \\
0,3441 \\
\hline
\end{tabular}


Os diâmetros externos adotados para os cascos de urânio foram:

Diâmetro externo do casco com 16 elementos: $d_{\mathrm{C} 16}=1,82 \mathrm{~m}$

Diâmetro externo do casco com 21 elementos: $d_{\mathrm{C} 21}=1,87 \mathrm{~m}$

Diâmetro externo do casco com 24 elementos: $d_{\mathrm{C} 24}=1,99 \mathrm{~m}$

Diâmetro externo do casco com 32 elementos: $d_{\mathrm{C} 32}=2,21 \mathrm{~m}$

d) Na comparação entre as dimensões dos cascos, tem-se:

\begin{tabular}{c|cccc}
\hline Dimensões & C16 & C21 & C24 & C32 \\
\hline C16 & 1,0000 & 1,0278 & 1,0911 & 1,2123 \\
C21 & 0,9729 & 1,0000 & 1,0616 & 1,1795 \\
C24 & 0,9165 & 0,9419 & 1,0000 & 1,1111 \\
C32 & 0,8248 & 0,8478 & 0,9000 & 1,0000 \\
\hline
\end{tabular}

e) De modo análogo aos cascos de ferro e de chumbo chega-se à:estimativa:

$$
\begin{aligned}
& 0,2692 \\
& 0,2619 \\
& 0,2467 \\
& 0,2221
\end{aligned}
$$

f) Ordenando todas as estimativas resultantes, têm-se as comparações iniciais:

\begin{tabular}{|l|l|l|}
\hline 0,0679 & 0,1618 & 0,7703 \\
\hline
\end{tabular}

g) Estimativa da comparação da massa, quantidade de combustível e dimensões,

\begin{tabular}{l|r|c|c|c|c}
\hline \multicolumn{2}{c|}{} & \multicolumn{2}{c|}{$\begin{array}{c}\text { Quantidade de combustível } \\
\text { por casco }\end{array}$} & \multicolumn{2}{c}{ Dimensões } \\
\hline C16 & 0,2948 & C16 & 0,1720 & C16 & 0,2692 \\
C21 & 0,2655 & C21 & 0,2258 & C21 & 0,2619 \\
C24 & 0,2412 & C24 & 0,2581 & C24 & 0,2467 \\
C32 & 0,1985 & C32 & 0,3441 & C32 & 0,2221 \\
\hline
\end{tabular}

h) Multiplicando-se as novas matrizes:

$$
\left|\begin{array}{rrr}
0,2948 & 0,1720 & 0,2692 \\
0,2655 & 0,2258 & 0,2619 \\
0,2412 & 0,2581 & 0,2467 \\
0,1985 & 0,3441 & 0,2221
\end{array}\right| \quad X \quad\left|\begin{array}{l}
0,0679 \\
0,1618 \\
0,7703
\end{array}\right|
$$

i) Resulta em:

\begin{tabular}{l|l|l}
\hline C16 & 0,2553 & \\
C21 & 0,2563 & $\rightarrow$ Maior valor, melhor opção \\
C24 & 0,2482 & \\
C32 & 0,2402 & \\
\hline
\end{tabular}


APÊNDICE D

CORTE LONGITUDINAL DO CASCO

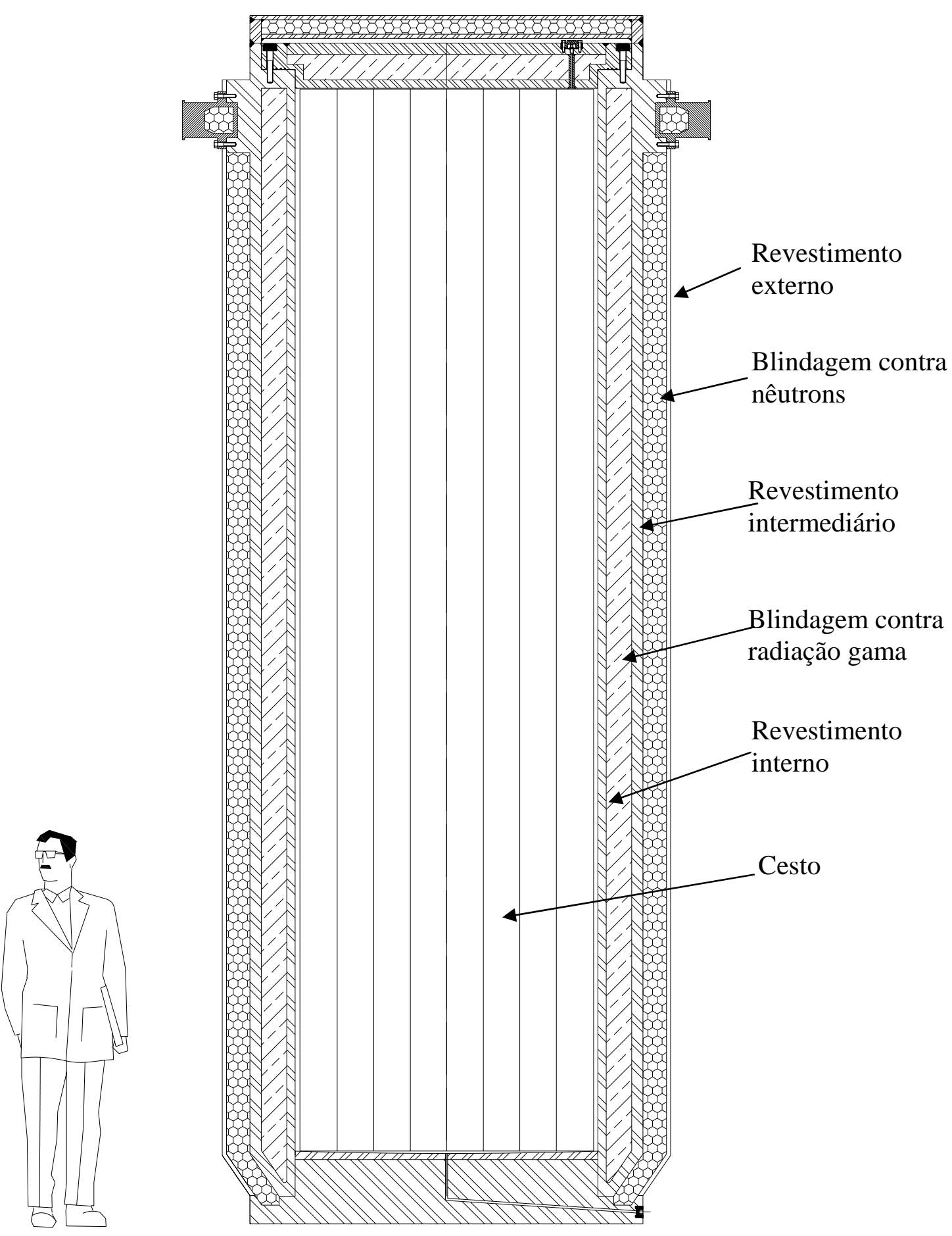




\section{APÊNDICE E \\ VISTA EXPLODIDA DOS COMPONENTES PRINCIPAIS DO CASCO}

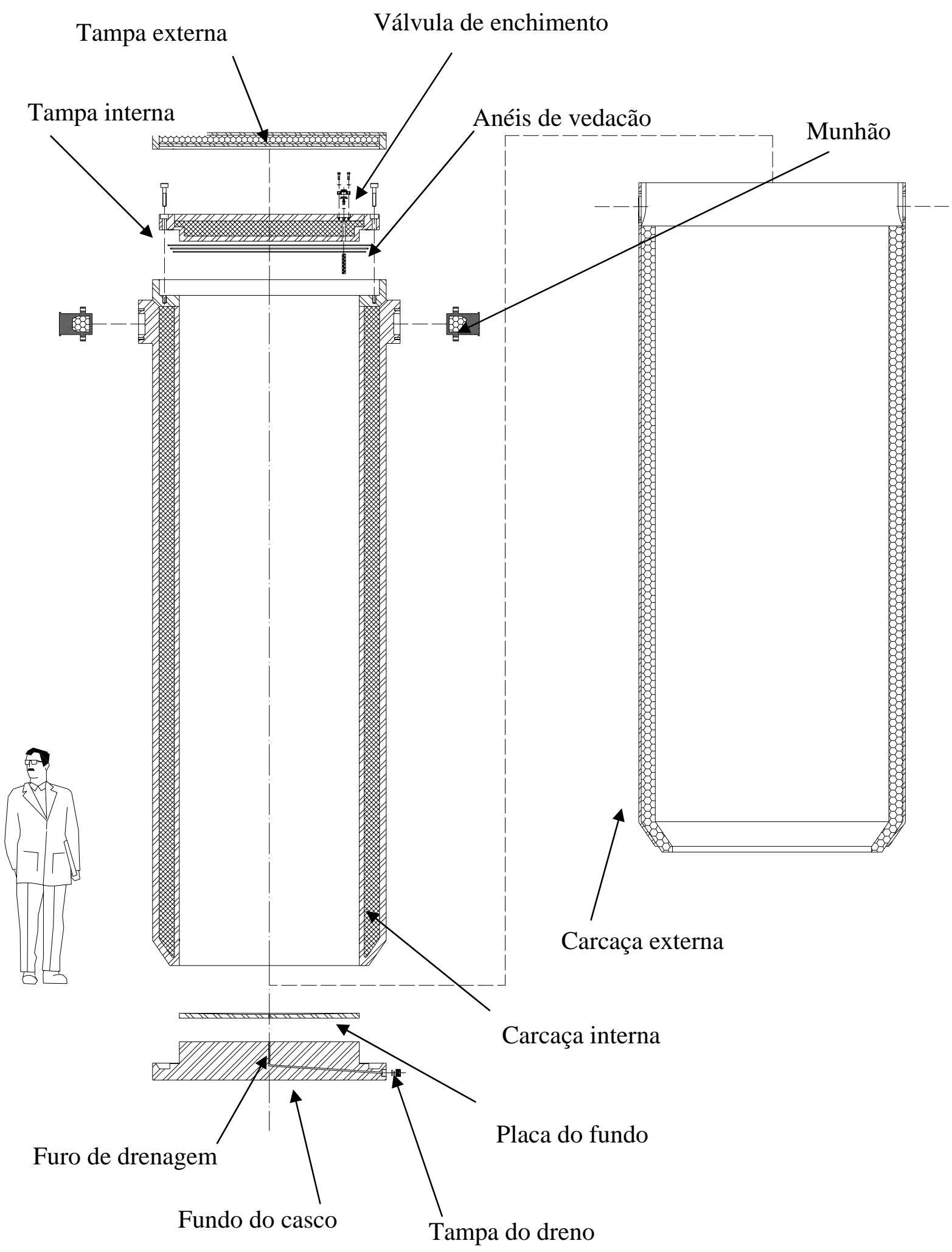




\section{APÊNDICE F}

\section{DETALHE DA TAMPA DO DRENO}

Tampa rosqueada no fundo do casco

Anéis vedadores

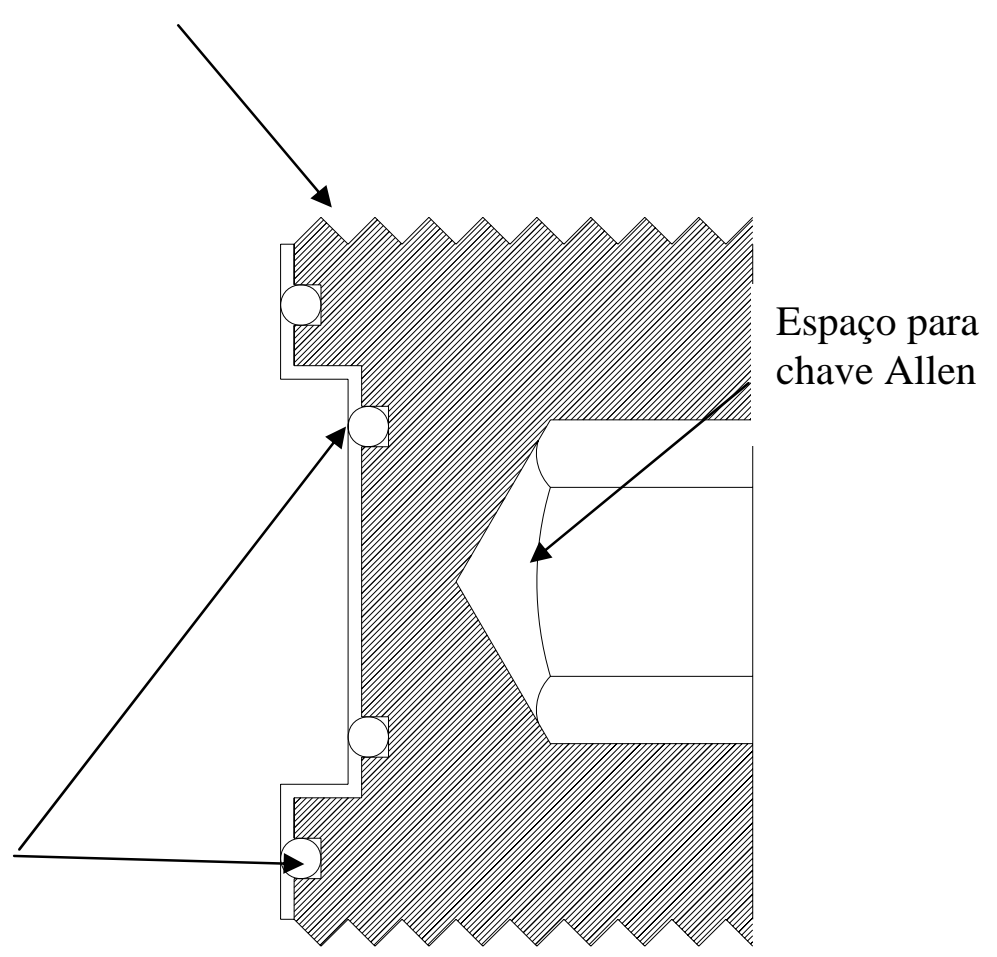


APÊNDICE G

CORTE DO CASCO DE ARMAZENAGEM

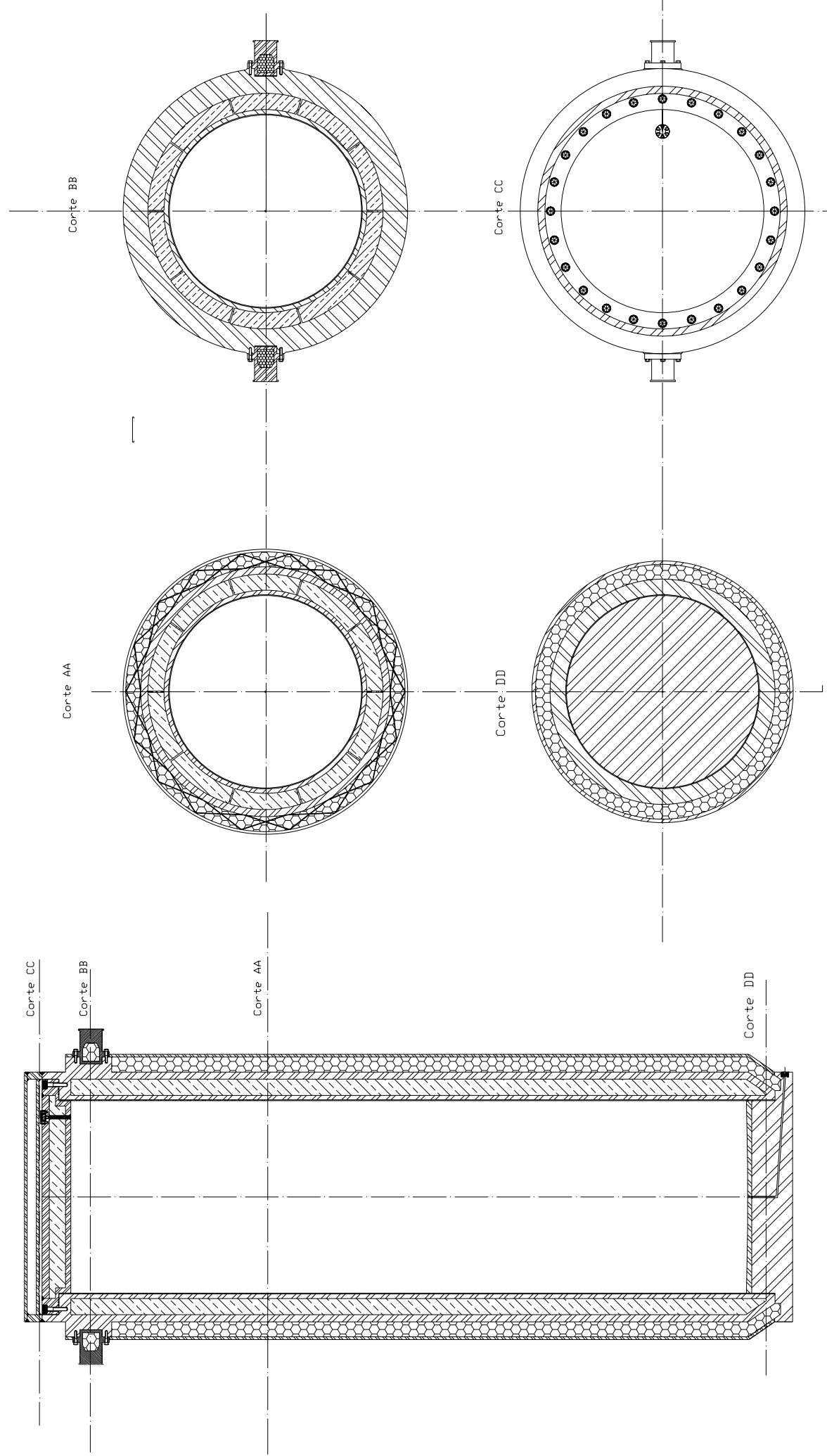




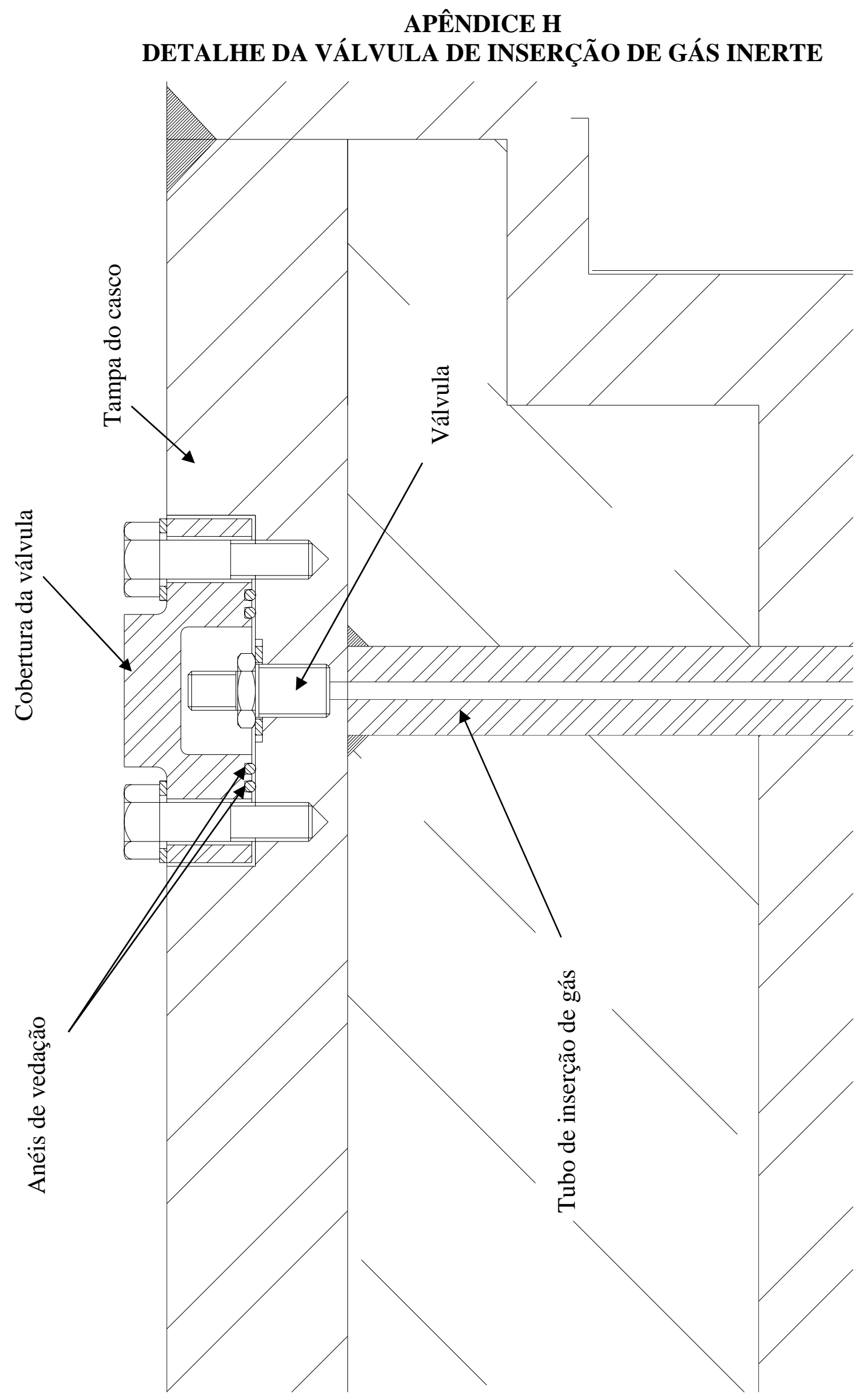




\section{APÊNDICE I}

\section{DETALHE DAS CÉLULAS DE ARMAZENAGEM DO CESTO}

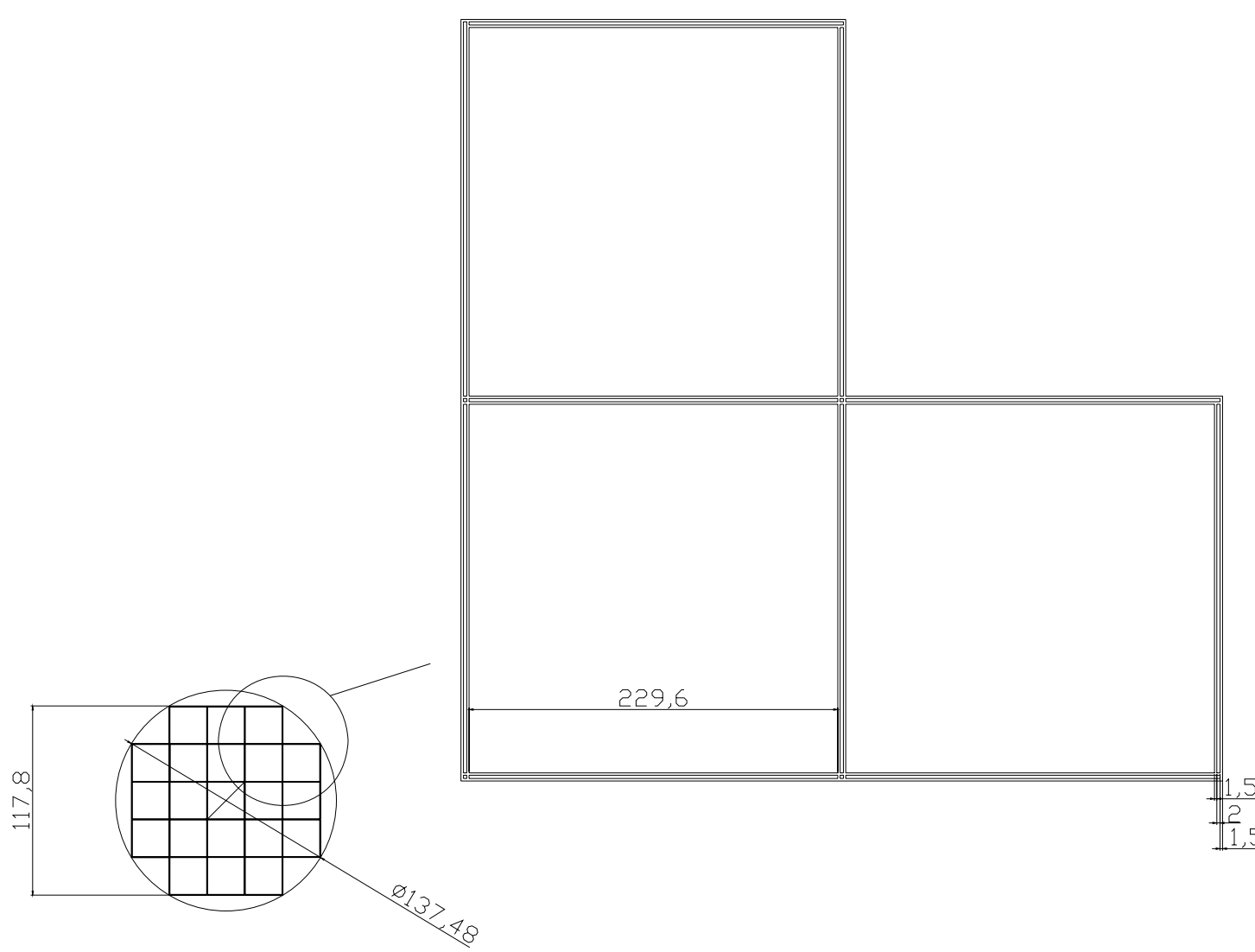

Medidas em mm 
APÊNDICE J

PLANTA BAIXA INSTALAÇÃO DE ARMAZENAGEM (PRIMEIRO MÓDULO)

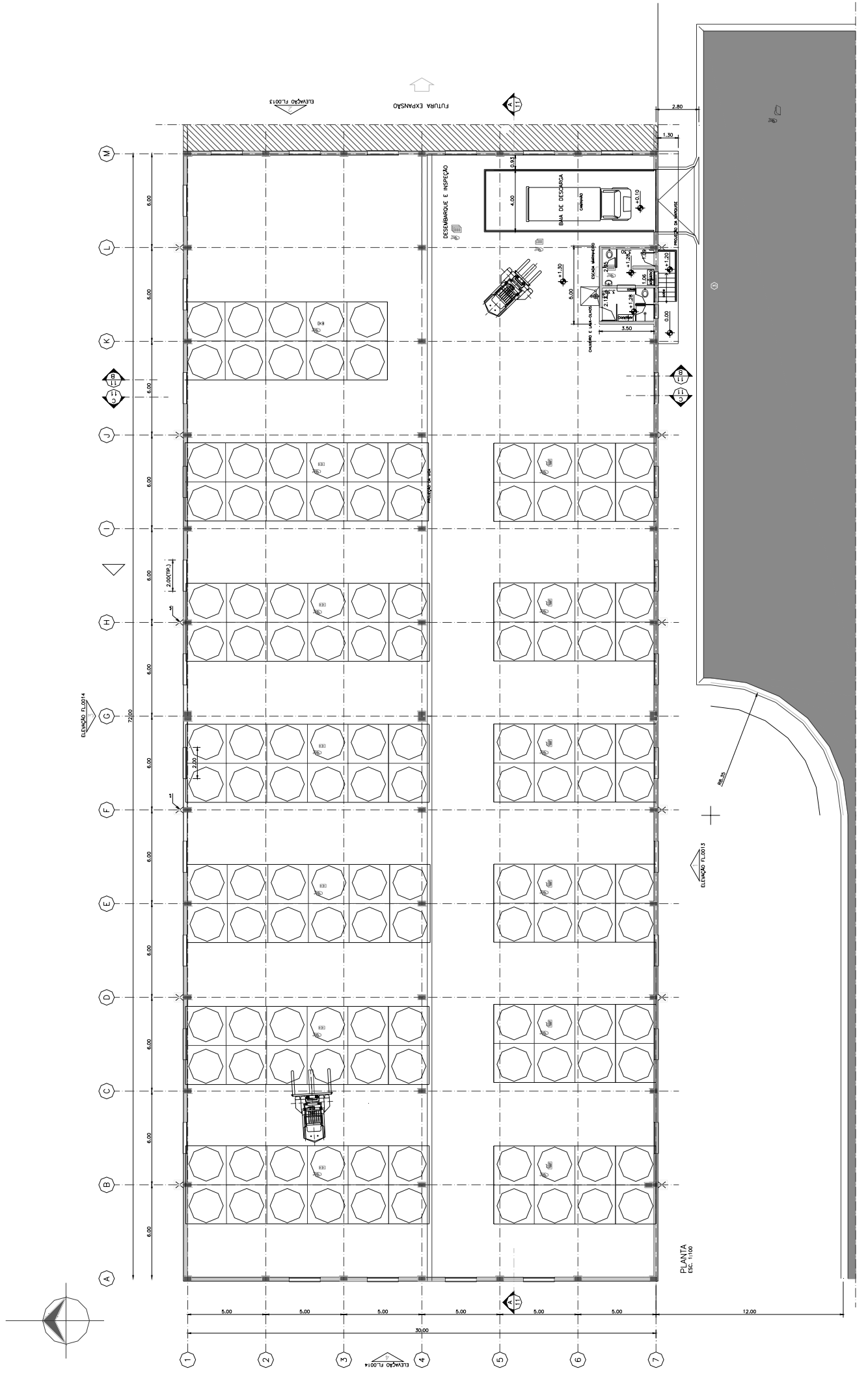


APÊNDICE K

CORTE FRONTAL DA INSTALAÇÃO DE ARMAZENAGEM

(PRIMEIRO MÓDULO)

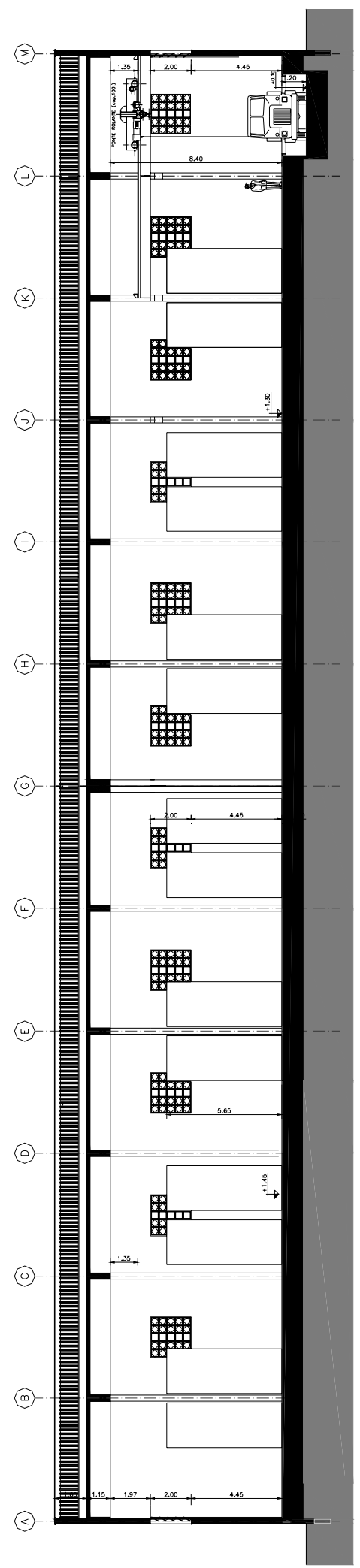


APÊNDICE L

CORTE LATERAL ESQUERDO DA INSTALAÇÃO DE ARMAZENAGEM (PRIMEIRO MÓDULO)

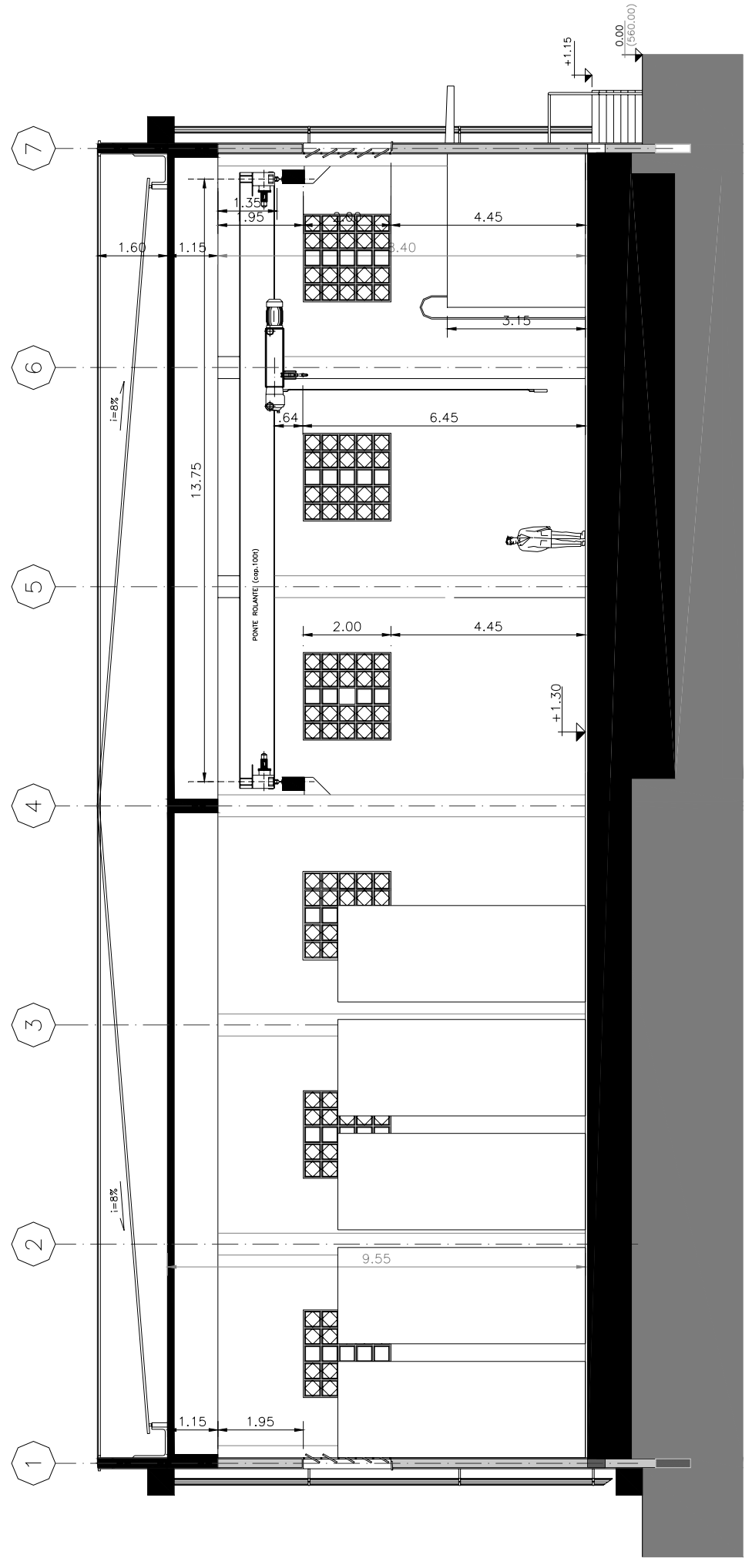


APÊNDICE M

CORTE LATERAL DIREITO DA INSTALAÇÃO DE ARMAZENAGEM

(PRIMEIRO MÓDULO)

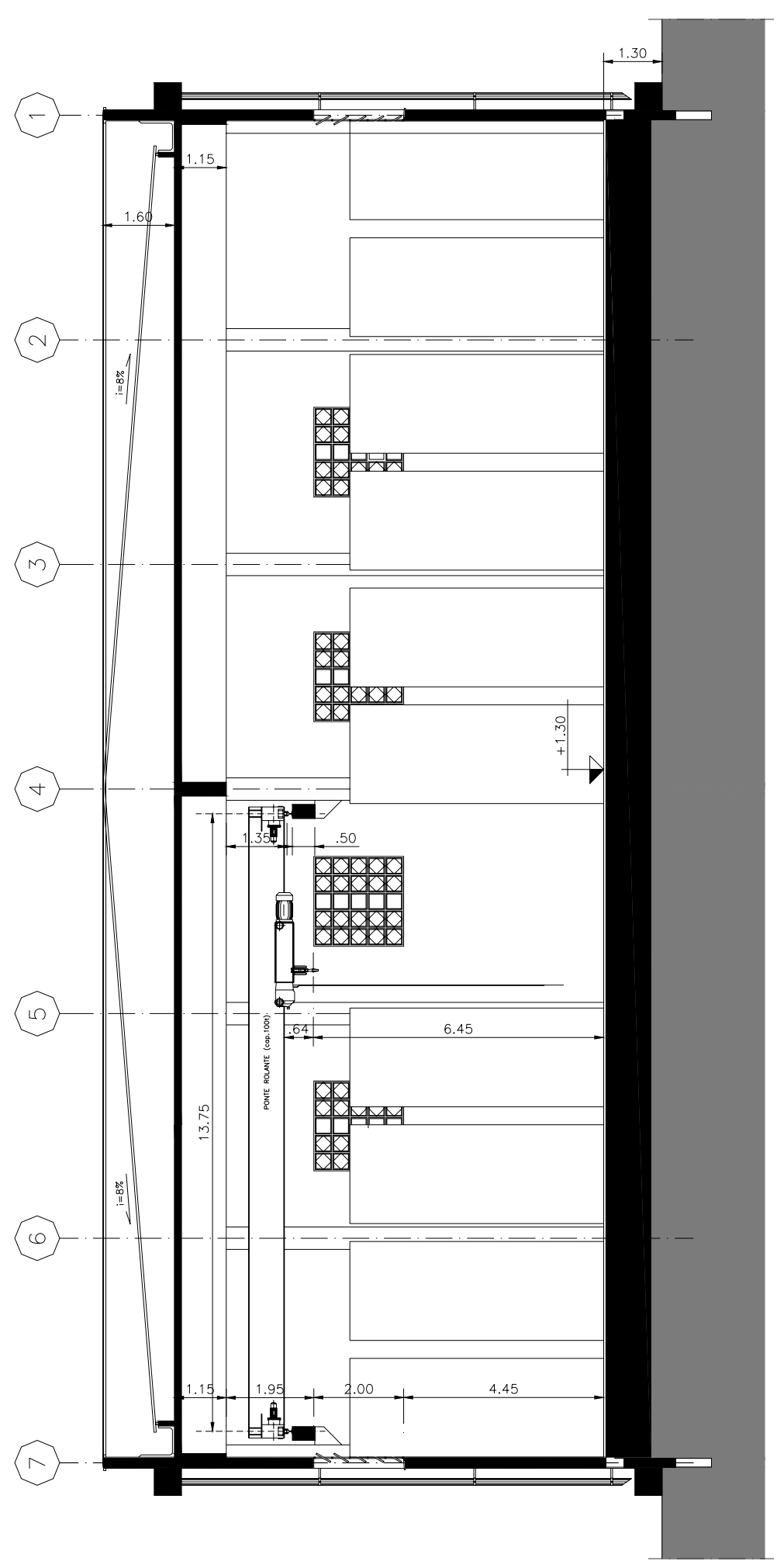


APÊNDICE N

PLANTA BAIXA DA INSTALAÇÃO DE ARMAZENAGEM COMPLETA

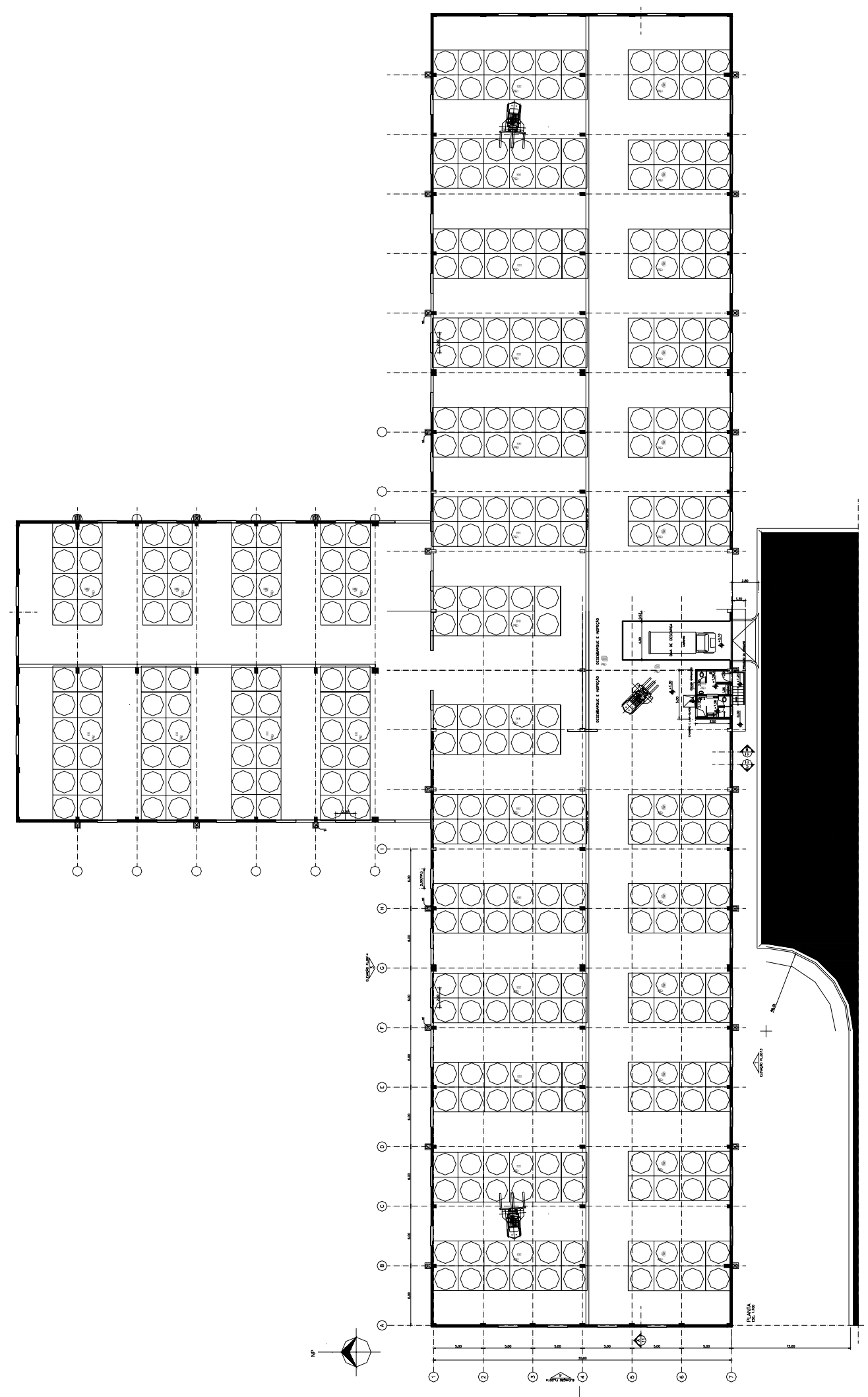


9 REFERÊNCIAS BIBLIOGRÁFICAS 


\section{REFERÊNCIAS BIBLIOGRÁFICAS}

ABNT - ASSOCIAÇÃO BRASILEIRA DE NORMAS TÉCNICAS, Sistemas de Gestão Ambiental - Diretrizes gerais sobre princípios, sistemas e técnicas de apoio. Norma ISO 14004:2005, ABNT, Brasil, 2005.

AHMED, W.; ARSHAD, M.; GHULAM QASIM, K. Dry storage of spent KANUPP fuel and booster rod assemblies. In: INTERNATIONAL CONFERENCE ON STORAGE OF SPENT FUEL FROM POWER REACTORS, Jun. 2 to 6, 2003, Vienna.

Proceedings... International Atomic Energy Agency, Vienna (Austria); Oct 2003. p.482 - 484. (IAEA-CN-102)

AMARAL, E.; BROCKMAN, K.; FORSSTRÖM, H. International perspectives on spent fuel management. In: INTERNATIONAL CONFERENCE ON MANAGEMENT OF SPENT FUEL FROM POWER REACTORS, Jun. 19-22, 2006, Vienna.

Proceedings... International Atomic Energy Agency, Vienna (Austria); 2007. p. 17-29 (IAEA-PUB-1295).

ANDERSSON, C.; ANDREWS, R. The development of advanced welding techniques for sealing nuclear waste canisters. In: 2001 MRS SPRING MEETING, Proceedings... April 2001, San Francisco, CA, USA (SKB TR-01-25)

ANL - ARGONNE NATIONAL LABORATORY - Computer Codes - Disponível em <http://www.ne.anl.gov/codes/>. Acesso em 18 nov. 2009.

ANSYS - Disponível em <http://www.ansys.com>. Acesso em 29 nov. 2009.

ASME. Boiler and Pressure Vessel Code - 2007 Edition. Disponível em $<$ http://www.asme.org/Codes/International_Boiler_pressure.cfm> . Acesso em 15 jan. 2009.

ASTM. Manual on Zirconium and Hafnium - STP639-EB (1977)

AUTODESK - Autocad 2010, Disponível em <http://www.autodesk.com.br/adsk/ servlet/index?siteID=1003425\&id=12306649>. Acesso em 29 nov. 2009.

BABCOCK - Disponível em <www.babcock.co.uk>. Acesso em 29 nov. 2009.

BAGGET, S.; BRACH, W. Regulatory body experiences in licensing and inspection of dry cask storage facilities. In: INTERNATIONAL CONFERENCE ON MANAGEMENT OF SPENT FUEL FROM POWER REACTORS, Jun. 19-22, 2006, Vienna.

Proceedings... International Atomic Energy Agency, Vienna (Austria); 2007. p. 315 321 (IAEA-PUB-1295). 
BAM - Bundesanstalt für Materialforschung und-prüfung . Disponível em <http://www.bam.de>. Acesso em 16 Nov 2009.

BEST, R.; BHANDORI, V.; CREEDEN, R.; MASON, M.; POINTER, H.; ROLLINS, J.; SCHEIBER, R. Spent fuel casks. Nuclear Assurance Corp., Georgia, USA. U.S.

Patent 4.336.460, 1982.

BIRO, L.; RODNA, A. Implementation of Romanian NPP spent fuel management strategy. A regulatory approach. In: INTERNATIONAL CONFERENCE ON STORAGE OF SPENT FUEL FROM POWER REACTORS, Jun. 2 to 6, 2003, Vienna.

Proceedings... International Atomic Energy Agency, Vienna (Austria); Oct 2003. p. 49-60. (IAEA-CN-102).

BLUM, P.; MEYER, P. Stowage rack for nuclear fuel Elements, Transnucleaire, Paris, France. U.S. Patent 5.032.348, 1991.

BNG - Disponível em <http://bngfuelsolutions.com>.Acesso em 21 ago. 2009.

BRASIL. Lei $n^{\circ} .6 .938$ - Política Nacional do Meio Ambiente. Diário Oficial da União, Brasília, DF. Set. 1981

BRASIL. Lei nº 10.308 - Seleção de locais, a construção, o licenciamento, a operação, a fiscalização, os custos, a indenização, a responsabilidade civil e as garantias referentes aos depósitos de rejeitos radioativos. Diário Oficial da União, Brasília, DF. Nov. 2001.

BUNN, M.; HOLDREN, J.; MACFARLANE, A.; PICKETT, S.; SUZUKI, A.; SUZUKI, T.; WEEKS. J. Interim Storage of Spent Fuel: A Safe, Flexible, and Cost-Effective Near-Term Approach to Spent Fuel Management. Harvard University and University of Tokyo. Jun, 2001.

CEPAGRI - CENTRO DE PESQUISAS METEOROLÓGICAS E CLIMÁTICAS APLICADAS A AGRICULTURA. UNICAMP. Disponível em:

http://www.cpa.unicamp.br/artigos-especiais/vendavais.html. Acesso em 11 Jun 2009. CNEN - COMISSÃO NACIONAL DE ENERGIA NUCLEAR. Norma CNEN-NE-6.05 Gerência de Rejeitos Radioativos em Instalações Radiativas. CNEN, Brasil, 1985 CNEN - COMISSÃO NACIONAL DE ENERGIA NUCLEAR. Norma CNEN-NE-5.02 Transportes, Recebimento, Armazenagem e Manuseio de Elementos Combustíveis de Usinas Nucleoelétricas. CNEN, Brasil, Out. 1986

CNEN - COMISSÃO NACIONAL DE ENERGIA NUCLEAR. Norma CNEN-NE-5.01 Transporte de Materiais Radioativos. CNEN, Brasil, Ago. 1988 
CNEN - COMISSÃO NACIONAL DE ENERGIA NUCLEAR. Norma CNEN-NE-6.06 Seleção e Escolha para Locais de Depósitos de Rejeitos Radioativos. CNEN, Brasil, 1989.

CNEN - COMISSÃO NACIONAL DE ENERGIA NUCLEAR. Norma CNEN-NN-1.16 Garantia da Qualidade para a Segurança de Usinas Nucleoelétricas e Outras Instalações. CNEN, Brasil, Abr. 2000

CNEN - COMISSÃO NACIONAL DE ENERGIA NUCLEAR. Norma CNEN-NE-1.04 -

Licenciamento de Instalações Nucleares. CNEN, Brasil, Dez. 2002

CNEN - COMISSÃO NACIONAL DE ENERGIA NUCLEAR. Norma CNEN-NN-3.01 -

Diretrizes Básicas de Proteção Radiológica. CNEN, Brasil, Jan. 2005

CNEN - COMISSÃO NACIONAL DE ENERGIA NUCLEAR. Fourth National Report

of Brazil for the Nuclear Safety Convention. CNEN, Brazil, Sep. 2007.

CNEN - COMISSÃO NACIONAL DE ENERGIA NUCLEAR. National Report of Brazil

2008 for the 3rd Review Meeting of the Joint Convention on the Safety of Spent

Fuel Management and on the Safety of Radioactive Waste Management. CNEN, Brazil, Oct 2008.

COCHRAN, R.; TSOULFANIDIS, N. The Nuclear Fuel Cycle: Analysis and

Management. American Nuclear Society, USA, 1992.

COUFAL, J.; BRZOBOHATÝ, K. Spent fuel storage facilities in the Czech Republic. In: INTERNATIONAL CONFERENCE ON STORAGE OF SPENT FUEL FROM POWER REACTORS, Jun. 2-6, 2003, Vienna. Proceedings... International Atomic Energy Agency, Vienna (Austria); Oct 2003. p. 22-24 (IAEA-CN-102).

CUMO, M.; TRIPPUTI, I.; SPEZIA, U. Nuclear Plant Decommissioning - Technology, cost evaluation, management, regulation, safety, health and environmental protection. Universtità di Roma “La Sapienza”, Roma, Italia, 2004.

DIONISI, M. Installations for the storage of spent fuel conditioning facilities geology,

Esarda Bulletin, 30 Dec. 1999, European Safeguard Research and Development Association, 1999.

DOE (U.S. DEPARTMENT OF ENERGY). Transportation Packaging Quick Facts, GNS 16 folder. Rev. 01, Sep. 2001, U.S.A.

DOE (U.S. DEPARTMENT OF ENERGY). NSNFP Activities in Support of Repository Licensing for Disposal of DOE SNF, DOE/SNF/REP-091 Rev. 0, Sep. 2004, U.S.A. 
DOW - DOW QUÍMICA, Plásticos América Latina - Disponível em $<$ http://plastics.dow.com/la/port/prod/polyethylene/ hdpe.htm>. Acesso em 29 nov. 2009.

DOWNWINDERS. Disponível em <http://www.downwinders.org/fuel.jpg>. Acesso em 8 out. 2006.

DUDERSTADT, J.J.; HAMILTON, L.J. Nuclear Reactor Analysis, John Wiley \& Sons, Inc. New York, U.S.A., 1976

EARLE, O. K. Options for the Handling and Storage of Nuclear Vessel Spent Fuel CaskIn: NATO WORKSHOP, Moscow, Russia, Apr. 22 - 24, 2002.

FAIRLIE, I. Dry storage of spent nuclear fuel: the safer alternative to reprocessing. Report to Greenpeace International in response to Cogema dossiers to the La Hague public inquiry. London, May 2000.

FLUENT, Spent Fuel Heat-up. Aplication Briefs from Fluent, EX 155, Fluent Inc. USA (2001)

FORSBERG, C.; HAIRE, M. Depleted Uranium Dioxide-Steel Cermets for Spent-NuclearFuel Multipurpose Casks. In: AMERICAN NUCLEAR SOCIETY 5TH TROPICAL MEETING, Proceedings... Charleston, USA, Sep. 17 to 20, 2002.

FORSBERG, C. A Multi-Functional Cermet Spent-Nuclear-Fuel Super Cask-In: INSTITUTE OF NUCLEAR MATERIALS MANAGEMENT 44TH ANNUAL MEETING, Proceedings... Phoenix, AZ, USA, Jul. 13 to 17, 2003.

FORSBERG, C. A Multifunction Cask for at-reactor storage of short-cooled SNF, transport and disposal. In: INTERNATIONAL TOPICAL MEETING ON ADVANCED NUCLEAR INSTALATION SAFETY, Proceedings... American Nuclear Society, San Francisco, CA, USA, May 2 to 6, 2004.

FRAJNDLICH, R. The Operational and Logistic Experience on Transportation of Brazilian Spent Nuclear fuel to the United States of America. In: Return of Research Reactor Spent Fuel to the Country of Origin: Requirements for Technical and Administrative Preparations and National Experiences, Proceedings... Aug. 28 to 31, 2006. IAEA-TECDOC-1593, Vienna, Austria, 2008.

FREEDOM FOR FISSION. Fuel Cycle. Heel-deep in it., 2006. Disponível em <http://www.freedomforfission.org.uk/cyc/waste.html>. Acesso em 28 jul. 2009.

GLASSTONE, S.; SESONSKE, A. Ingenieria de Reactores Nucleares - Versión española. Editorial Reverté. España, 1975.

GNS. Geschäftsfelder. Disponível em <www.gns.de>. Acesso em 24 jun. 2007. 
GOLL, W.;MCCOY, K.; GARNER, G.L.; NISSEN, K.; HOFFMANN, D.; DYCK, P. Trends in dry spent fuel storage and transport in Germany and the United States of America. In: INTERNATIONAL CONFERENCE ON MANAGEMENT OF SPENT FUEL FROM POWER REACTORS, Jun. 19-22, 2006, Vienna. Proceedings... International Atomic Energy Agency, Vienna (Austria); 2007. p. 395-408 (IAEAPUB-1295).

GÖHRING, R.; et al. Design, Construction and Commissioning on an Interim Spent Fuel Store do the Decommissioning of Ignalina NPP, Lithuania - ATW International Journal for Nuclear Power - atw 50. Jg. (2005) Heft 4 - Apr, Berlin, Germany, pp. 229-232, 2005

GOOGLE EARTH. Versão 4.3 - abril 2008. Disponível em <earth.google.com>. Foto obtida em 10 jan. 2009.

GREGORIC, M. Spent Fuel: Nuclear security issues. In: INTERNATIONAL CONFERENCE ON MANAGEMENT OF SPENT FUEL FROM POWER REACTORS, Jun. 19-22, 2006, Vienna. Proceedings... International Atomic Energy Agency, Vienna (Austria); 2007. p. 101-113 (IAEA-PUB-1295).

HAIRE, M.J.; DOLE, L.R.; ARROWSMITH H.W.; DENTON, M.S. A Collaboration to Develop the Next-Generation SNF/HLW Cask. In: INTERNATIONAL HIGHLEVEL RADIOACTIVE WASTE MANAGEMENT CONFERENCE, Proceedings... Las Vegas, Nevada, USA. Mar 30 to Apr 2, 2003.

HAIRE, M.J.; FORSBERG, C.W.; MATVEEV, V.Z.; SHAPOVALOV, V.I. Characteristics of next generation Spent Nuclear Fuel (SNF) transport and storage casks. In: AMERICAS NUCLEAR ENERGY SYMPOSIUM, Proceedings..., Florida, USA, Oct. 3 to 6, 2004.

HALSTEAD, R.J.; DILGER, F. Full-scale Cask Testing Revisited, Again. In: WM’06 CONFERENCE, Feb. 27 to Mar.2, 2006, Tucson, AZ, USA. Proceedings... 2006

HANSON, A.; CHOLLET, P. International experience of storing spent fuel in NUHOMS® systems. In: INTERNATIONAL CONFERENCE ON STORAGE OF SPENT FUEL FROM POWER REACTORS, Jun. 2 to 6, 2003, Vienna. Proceedings... International Atomic Energy Agency, Vienna (Austria); Oct 2003. p. 168-178 (IAEA-CN-102).

HAYASHI, T. Compact Fusion Reactor using Advanced Shield Materials - Application of Hydrogen-Rich Hydride to the Shield of Fusion Reactor, Nuclear Fusion Research and Development, JAEA R\&D Review, 2006. 
HELD, CH.; HINTERMAYER, H. Comparison of concepts for independent spent fuel storage facilities. In: STORAGE OF SPENT FUEL ELEMENTS. Madrid, Jun. 1978. Proceedings...Organization for Economic Co-operation and Development OECD, Paris, 1978. p.179-195.

HIRSCH, H.; NEUMANN, W. Verwundbarkeit von CASTOR-Behältern bei Transport und Lagerung gegenüber terroristischen und kriegerischen Einwirkungen sowie zivilisatorischen Katastrophen, BUND-Studie: Verwundbarkeit von CASTORBehältern, Hannover, Deutschland, Nov. 2001.

HONDORP, H. Neutron and gamma radiation shielding material, structure, and process of making structure., U.S. Patent 4.437.013, 1984.

IAEA - INTERNATIONAL ATOMIC ENERGY AGENCY. Handling and Storage of Conditioned High-Level Wastes. Vienna, Austria, 1983. (Technical Report Series, 229).

IAEA - INTERNATIONAL ATOMIC ENERGY AGENCY. Survey of experience with dry storage of spent nuclear fuel and update of wet storage experience. Vienna, Austria, 1988. (Technical Report Series, 290).

IAEA - INTERNATIONAL ATOMIC ENERGY AGENCY. Cost analysis methodology of spent fuel storage. Vienna, Austria, 1994. (Technical Report Series, 361).

IAEA - INTERNATIONAL ATOMIC ENERGY AGENCY. Design of spent fuel storage facilities. Vienna, Austria, 1994a. (Safety Series, 116).

IAEA -INTERNATIONAL ATOMIC ENERGY AGENCY. Survey of wet and dry spent fuel storage. Vienna, Austria, 1999. (IAEA TECDOC 1100)

IAEA -INTERNATIONAL ATOMIC ENERGY AGENCY. Spent fuel storage and Transport Cask Decontamination and Modification. Vienna, Austria, 1999a. (IAEA TECDOC 1081)

IAEA - INTERNATIONAL ATOMIC ENERGY AGENCY. Multipurpose container technologies for spent fuel management. Vienna, Austria, 2000 (IAEA TECDOC 1192)

IAEA - INTERNATIONAL ATOMIC ENERGY AGENCY. Country nuclear fuel cycle profiles. Vienna, Austria, 2001. (Technical Report Series, 404).

IAEA - INTERNATIONAL ATOMIC ENERGY AGENCY. Long term storage of spent nuclear fuel - Survey and recommendations. Vienna, Austria, May 2002. (IAEA TECDOC 1293) 
IAEA - INTERNATIONAL ATOMIC ENERGY AGENCY. Spent fuel performance Assessment and Research. Vienna, Austria, 2003 (IAEA TECDOC 1343)

IAEA - INTERNATIONAL ATOMIC ENERGY AGENCY. Storage of Spent Fuel from Power Reactors. 2-6 jun. 2003, Conference Proceedings... International Atomic Energy Agency, Vienna (Austria); 2003a

IAEA - INTERNATIONAL ATOMIC ENERGY AGENCY. Remote Technology Applications in Spent Fuel Management. Vienna, Austria, 2005 (IAEA TECDOC 1433)

IAEA - INTERNATIONAL ATOMIC ENERGY AGENCY. Regulations for the Safe Transport of Radioactive Material. Vienna, Austria, 2005a (Safety Standard Series TS-R-1)

IAEA - INTERNATIONAL ATOMIC ENERGY AGENCY. Optimization Strategies for Cask Design and Container Loading in Long Term Spent Fuel Storage. Vienna, Austria, 2006 (IAEA TECDOC 1523)

IAEA - INTERNATIONAL ATOMIC ENERGY AGENCY. Data Requirements and Maintenance of Records for Spent Fuel Management: A Review. Vienna, Austria, 2006a (IAEA TECDOC 1519)

IAEA - INTERNATIONAL ATOMIC ENERGY AGENCY. Operation and Maintenance of Spent Fuel Storage and Transportation Casks/Containers technology applications in spent fuel management. Vienna, Austria, 2007 (IAEA TECDOC 1532)

IAEA - INTERNATIONAL ATOMIC ENERGY AGENCY. Management of Spent Fuel From Nuclear Power Reactors. 19-22 june 2006, Proceedings... International Atomic Energy Agency, Vienna (Austria); 2007a

IBAMA. Processo de licenciamento ambiental. Disponível em <http://www.ibama.gov. br/licenciamento/>. Acesso em 09 jan. 2009.

IKONEN, K. Thermal Analysis of Repository for Spent EPR-type Fuel, Report POSIVA 2005-06, Sep. 2005, Posiva Oy, Olkiluoto, Finland, 2005

INB - INDÚSTRIAS NUCLEARES BRASILEIRAS. Elemento combustível. Disponível em <http://www.inb.gov.br/elemento.asp>. Acesso em 07 jan. 2009.

INDIAN POINT ENERGY CENTER. Disponível em < http://www.safesecurevital.org/ articlessafe-secure-vital/dry-cask-storage.html>. Acesso em 25 nov. 2008. INL - IDAHO NATIONAL LABORATORY. National spent nuclear fuel program. Disponível em < https://inlportal.inl.gov> . Acesso em 29 nov. 2009. 


\section{INTEGRATED NUCLEAR FUEL CYCLE INFORMATION SYSTEM. International}

Atomic Energy Agency. Vienna. Disponível em <http://www-nfcis.iaea.org/Default. asp> . Acesso em 25 nov. 2008

ISSARD, H. Anticipating future needs for the transport and storage of spent fuel from evolutionary nuclear power reactors. In: INTERNATIONAL CONFERENCE ON MANAGEMENT OF SPENT FUEL FROM POWER REACTORS, Jun. 19-22, 2006, Vienna. Proceedings... International Atomic Energy Agency, Vienna (Austria); 2007. p. 341-351 (IAEA-PUB-1295).

JOHN CAUNT SCIENTIFIC LTD. Polyethhylene Neutron Shielding. Disponível em $<$ http:॥www.johncaunt.com/pages/shielding/shielding.html>. Acesso em 17 nov. 2008.

JONES, K; LEHNERT, R.; MCINNES, I.; QUINN, R.; SISLEY, S.; TEMUS, C. Transportation and storage cask for spent nuclear fuels. Pacific Nuclear Systems, Inc., Washington, USA. U.S. Patent 5.546.436, 1996.

KAWAKAMI, K.; OZAKI, S.; NAKATANI, T.; MATSUMOTO, M. Design of Spent Fuel Transportable Storage Cask. . In: $14^{\text {th }}$ INTERNATIONAL SYMPOSIUM ON THE PACKAGING AND TRANSPORTATION OF RADIOACTIVE MATERIALS, Sep. 20 to 24, 2004, Berlin, Germany. Proceedings... PATRAM, 2004.

KHAN, A.; KING, F. Regulatory approval of used fuel dry storage facilities in Canada, An Ontario Power Generation case study. In: INTERNATIONAL CONFERENCE ON STORAGE OF SPENT FUEL FROM POWER REACTORS, Jun. 2 to 6, 2003, Vienna. Proceedings... International Atomic Energy Agency, Vienna (Austria); Oct 2003. p. 240-249 (IAEA-CN-102/6)

KOMAROVSKII, A. N. - Shielding Materials for nuclear reactors. Vol. 1, Pergamon Press. London, UK, 1961

KULKARNI, W. B.; SONI, R. S.; AGARWAL, K. Spent fuel storage in India. In: INTERNATIONAL CONFERENCE ON STORAGE OF SPENT FUEL FROM POWER REACTORS, Jun. 2 to 6, 2003, Vienna. Proceedings... International Atomic Energy Agency, Vienna (Austria); Oct 2003. p. 30-36 (IAEA-CN-102/24)

LABFIT - LAB Fit Ajuste de Curvas - Disponível em <http://zeus.df.ufcg.edu.br/labfit/ index_p.htm>. Acesso em 29 nov. 2009.

LAMARSH, J.; BARATTA, A. Introduction to Nuclear Engineering - Third Edition. Prentice-Hall Inc. New Jersey, USA. 2001 
L.A. SUN - Las Vegas Sun. Disponível em < http://www.lasvegassun.com/sunbin/ stories/sun/1999/dec/05/c00015325.html>. Acesso em 29 nov. 2009.

LEE, J.C.; KIM, D.H.; BANG, K.S.; SEO, K.S.; CHOI, B.I.; LEE, H.Y. Thermal Analysis of a Storage Cask for 24 Spent PWR Fuel Assemblies. Packaging Transport, Storage and Security of Radiactive Material, 2005; 16(1):19-26(8).

LIDSKOG, R.; ANDERSSON, A. The management of radioactive waste. A description of ten countries. Svensk Kärnbränslehantering AB, Sweden, 2002.

LIETAVA, P.; BARTÁK, L.; KUBA, S. Current status of the spent fuel management from power reactors in the Czech Republic - Licensing and operational experience. In: INTERNATIONAL CONFERENCE ON STORAGE OF SPENT FUEL FROM POWER REACTORS, Jun. 2 to 6, 2003, Vienna. Proceedings... International Atomic Energy Agency, Vienna (Austria); Oct 2003. p. 250-260. (IAEA-CN-102/11).

LOS ALAMOS NATIONAL LABORATORY, A Review of Criticality Accidents, LA 13638, Los Alamos, USA, 2000.

LUSK, E.; RIDIHALGH, J. Shipping and storage container for spent nuclear fuel. Mitsubishi Heavy Industries, Ltd, Tokyo, Japan, U.S. Patent 4.666.659, 1987. LUZ, A.B.; BALTAR, C. A. M. Comunicação Técnica Elaborada para Edição do Livro Rochas \& Minerais Industriais: Usos e Especificações, Pág. 263 A 277. CT2005118-00. Capítulo 12 - Barita. Centro de Tecnologia Mineral, Brasil, 2005

MAIORINO, J. R; FRAJNLICH, R.; MANDLA, M; BENSBERG, M.; GRABOW, K. The operational and logistic experience on transportation of Brazilian spent fuel to USA. RERTR, 2000

MAIORINO, J. R; NOVARA, O.; SOARES, A. J.; KLEI, J.; MAZÓN, R.; LLAMAS. I.; RITCHIE, I.; GUARNIZO. J.. Management of spent fuel from research reactors in Latin America: a regional approach. In: 2002 International Meeting on Reduced Enrichment for Research and Test Reactors, Bariloche, Argentina. Nov. 3 to 8, 2002. MARCELLI, D.; SMITH, T. The Zaporozhye ISFSI - In: Radwaste Solutions - pp. 28-32 - Jan/Feb. 2002

MARSH, G.E.; STANFORD, G.S. Terrorism and Nuclear Power: What are the Risks?, Disponível em <http://www.nationalcenter.org/NPA374.html > (2001)

MARTÍNEZ, J. E.; GAGO, J. A. An update on spent fuel and HLW management in Spain. In: INTERNATIONAL CONFERENCE ON STORAGE OF SPENT FUEL FROM POWER REACTORS, Jun. 2-6, 2003, Vienna. Proceedings... International Atomic Energy Agency, Vienna (Austria); Oct 2003. p.64 - 69. (IAEA-CN-102) 
MATVEEV, V.Z.; MORENKO, A.I.; SHAPOLOVALOV, V.I.; MASLOV, A.A., ORLOV, V.K.; SEMENOV, A.G.; SERGEEV, V.M.; YUFEROV, O.I.; VISIK, A.M. Design of Transport Casks with Depleted Uranium Gamma Shield and Advanced Safety. In: $11^{\mathrm{TH}}$ INTERNATIONAL HIGH LEVEL RADIOACTIVE WASTE MANAGEMENT CONFERENCE (IHLRWM 2006), Apr 30 to May 4, Las Vegas, NV. Proceedings... American Nuclear Society, USA, 2006

McCOMBIE, C. Site Selection for Spent Fuel Storage and Disposal of High Level Waste: Experience of European Countries. An International Spent Nuclear Fuel Storage Facility . Exploring a Russian Site as a Prototype. Proceedings of an International Workshop. p.73 a 88. National Academies Press, Washington, DC, USA (2005) METALPRICES, Disponível em <www.metalprices.com> Acesso em 21 jan. 2009 MINISTÉRIO DE CIÊNCIA E TECNOLOGIA. Agência CT. Notícias. Brasil transporta material radioativo para os Estados Unidos. 14/11/2007. Brasil. Disponível em $<$ http://agenciact.mct.gov.br/index.php/content/view/46473.html>. Acesso em 25 nov. 2008.

MINISTÉRIO DE INDUSTRIA Y ENERGIA. Quinto plan general de residuos radiactivos. España, 1999.

MITSUBISHI NUCLEAR FUEL. PWR Fuel Assembly. 2006. Disponível em <http://www.mnf.co.jp/pages2/pwr2. htm>. Acesso em: 25 nov. 2008

MSC - MD Nastran. Disponível em <http://www.mscsoftware.com/Contents/Products/ CAE-Tools/MD-Nastran.aspx>. Acesso em 29 nov. 2009.

NAC INTERNATIONAL. Disponível em <http://www.nacintl.com>. Acesso em: 25 nov. 2008

NATIONAL RESEARCH COUNCIL. Safety and Security of Commercial Spent Nuclear Fuel Storage: Public Report. Committee on the Safety and Security of Commercial Spent Nuclear Fuel Storage. National Academies Press. Washington, DC, USA. 2006

NUCLEAR ENERGY AGENCY The Safety of Nuclear Fuel Cycle. 3 ed. 2005, n. 3588, cap 6, p.149-155

NUCLEAR ENERGy INSTITUTE. Soviet-Designed Nuclear Power Plants in Russia, Ukraine, Lithuania, Armenia, the Czech Republic, the Slovak Republic, Hungary and Bulgaria. NEI, Washington, Fifth Edition, 1997

NUCLEP - Nuclebrás Equipamentos Pesados - Disponível em <http://www.nuclep.gov. br>. Acesso em: 11 jun. 2009. 
OBSERVATÓRIO SISMOLÓGICO. Instituto de Geociências da Universidade de Brasília. Disponível em <http://www.obsis.unb.br>. Acesso em: 11 jun. 2009.

OFFICE OF CIVILIAN RADIOACTIVE WASTE MANAGEMENT - OCRWM. Switzerland's Radioactive Waste Management Program. Disponível em: <http://www.ocrwm.doe.gov/factsheets/doeymp0417.shtml>. Acesso em: 07 jun. 2009

ONTARIO POWER GENERATION. Darlington Waste Management Facility. Ontario Power Generation fact Sheet. Disponível em < http://www.opg.com/pdf/DarlInfoPkg. pdf>. Acesso em 25 jul 2009.

ORNL - RSIC CODE PACKAGE PSR-262 MICRO, Disponível em <http://wwwrsicc.ornl.gov/codes/psr/psr2/psr-262.html>. Acesso em 29 nov. 2009.

ORNL - SCALE Software, Disponível em <http://www.ornl.gov/sci/scale/>. Acesso em 29 nov. 2009a.

PENNINGTON, C.; MCGOUGH, M. Madness and spent fuel cask safety. Radwaste Solutions. p. 25-30, May/Jun. 2002.

PRUVOST, N. L.; PAXTON, H. C. Nuclear Criticality Safety Guide, LA-12808, Los Alamos National Laboratory, Los Alamos, New Mexico, U.S.A., 1996

QMETRICS - Engineering Analysis and Design. Disponível em <http://wwwqmetrics. com/csb.htm>. Acesso em 29 nov. 2009.

QUAPP, W. An Advanced Solution for the Storage, Transportation and Disposal of Spent Fuel and Vitrified High Level Waste. In: GLOBAL 99, Proceedings..., Aug. 29 to Sep. 2, Jackson, Wyoming, USA, 1999

RITCHIE, I. G. Growing dimensions, spent fuel management at research reactors. In: IAEA Bulletin No 40, 01/1998, Austria

ROLAND, V.; CHIGUER, M., GUÉNON, Y. Dry storage technologies: Keys to choosing among metal casks, concrete shielded steel canister modules and vaults . In: INTERNATIONAL CONFERENCE ON STORAGE OF SPENT FUEL FROM POWER REACTORS, Jun. 2 to 6, 2003, Vienna. Proceedings... International Atomic Energy Agency, Vienna (Austria); Oct 2003. p.107 - 123. (IAEA-CN-102)

ROMANATO, L.; RZYSKI, B. Levantamento dos aspectos ambientais no transporte de combustível nuclear queimado, da central nuclear para o local de armazenagem provisória. In: VI CONGRESO REGIONAL SOBRE SEGURIDAD RADIOLÓGICA Y NUCLEAR. CONGRESO REGIONAL IRPA, Proceedings... 9 to 13 nov. 2003, Lima, Peru. 1 CD-ROM. 
ROMANATO, L.; RZYSKI, B. Avaliação do Impacto Ambiental por Transporte de Combustível Nuclear Queimado. In: INTERNATIONAL NUCLEAR ATLANTIC CONFERENCE, INAC 2005. Proceedings...Aug 28 to Sep 2, Santos, Brazil. 2005. ROMANATO, L.; RZYSKI, B. Advantages on Dry Interim Storage for Spent Nuclear Fuel. In: FIRST AMERICAN IRPA CONGRESS 2006. Proceedings... Sep 3 to 8, Acapulco. Mexico. 2006.

ROMANATO, L.; RZYSKI, B. Safety Aspects of Spent Nuclear Fuel Interim Storage Installations. In: INTERNATIONAL NUCLEAR ATLANTIC CONFERENCE, INAC 2007. Proceedings...Sep 30 to Oct 5, Santos, Brazil. 2007.

ROMANATO, L.; RZYSKI, B. Why is a Dry Storage for Spent Nuclear Fuel Waste More Appropriate? In: INTERNATIONAL NUCLEAR ATLANTIC CONFERENCE, INAC 2007. Proceedings...Sep 30 to Oct 5, Santos, Brazil. 2007a.

ROMANATO, L. Armazenagem de Combustível Nuclear Queimado. 2005. Dissertação (Mestrado em Tecnologia Nuclear - Aplicações). Instituto de Pesquisas Energéticas e Nucleares, Universidade de São Paulo, São Paulo, 2005.

ROMANATO, L. Relatório de Acompanhamento de Ensaios no CDTN. Ensaio para validação do projeto de um casco de transporte para combustível queimado para reator de pesquisas. Centro de Desenvolvimento de Tecnologia Nuclear, CNEN, Belo Horizonte, MG, Relatório para o CTMSP, 2008.

ROSHAN, A.D.; SHYLAMONI, P.; SOURAV, A. Monograph on Siting of Nuclear Power Plants. Civil \& Structural Engineering Division, Atomic Energy Regulatory Board, Mumbai, India, 2005.

RYHÄNEN, V. Siting of radioactive waste management facilities. Safety of radioactive waste management. In PROCEEDING OF AN INTERNATIONAL CONFERENCE, IAEA, Proceedings... Cordoba, Spain, p.127-136, Mar. 13 to 17, 2000.

SAATY, T. L. The Analytic Hierarchy Process: Planning, Priority, Setting, Resource Allocation. McGraw Hill International Book Company, New York, USA, 1980 SEVERA, J.; BAR, J. Handbook of radioactive contamination and decontamination. Studies in environment science. v. 47. Elsevier, Amsterdam, Holland, 1991.

SHAH, M.; COX, P. A.; CHOWDHRRY, A. H.; Tip-Over Analysis of the HI-STORM Dry Storage Cask System. Transactions of the $17^{\text {th }}$ Intenational Conference on Structural Mechanics in Reactor Technology (SMiRT 17), Aug. 17 to 22, 2003, Prague, Czech Republic, 2003 
SHAPOVALOV, V.I.; MATVEEV, V.Z.; SEMENOV, A.G.; SERGEEV, V.M.; ORLOV, V.K.; GOTOVCHIKOV, V.T.; SEREDENKO, V.A., SHALATOV, V.V.; HAIRE, J.M.; FORSBERG, C.V. Conception of Universal Cask Based on Cermet for SNF Transportation and Storage. In: $11^{\mathrm{TH}}$ INTERNATIONAL HIGH LEVEL RADIOACTIVE WASTE MANAGEMENT CONFERENCE (IHLRWM 2006), Apr 30 to May 4, Las Vegas, NV. Proceedings... American Nuclear Society, USA, 2006 SHAPPERT, L.B. (Editor); et al. The radioactive materials packaging handbook. Design, operations and maintenance. ONRL/M-5003. Oak Ridge National Laboratory, Tennessee, USA. 1998.

SHIELDWERX ${ }^{\mathrm{TM}}$; SWX-201HD 5\% Borated Polyethylene Neutron Shielding. Catálogo de produto; Shielderwerx, Division of Bladewerx LLC, New Mexico, USA. 2007. SHIRAI, K.; TAKEDA, H.; WATARU, M.; SAEGUSA, T. Demonstration test programming using full scale metal and concrete casks. In: INTERNATIONAL CONFERENCE ON STORAGE OF SPENT FUEL FROM POWER REACTORS, Jun. 2 to 6, 2003, Vienna. Proceedings... International Atomic Energy Agency, Vienna (Austria); Oct 2003. p.353 - 368. (IAEA-CN-102)

SILVA, A.T.; et al. Análise de opções para o armazenamento temporário de combustíveis queimados do reator IEA-R1 do IPEN-CNEN/SP. In: INTERNATIONAL NUCLEAR ATLANTIC CONFERENCE, INAC 2005. Proceedings... Aug 28 to Sep 2, Santos, Brazil. 2005

SOARES, A.J.; SILVA, J.E.R. Management of spent fuel from research reactors Brazilian progress report. RERTR, 2004

SOLIGNAC, Y.; GEVORGYAN, A.; MARKOSYAN, G. The spent fuel storage solution in Armenia In: INTERNATIONAL CONFERENCE ON MANAGEMENT OF SPENT FUEL FROM POWER REACTORS, Jun. 19-22, 2006, Vienna. Proceedings... International Atomic Energy Agency, Vienna (Austria); 2007. p. 295305 (IAEA-PUB-1295)

SPENT FUEL NEWS. Dry cask storage of spent fuel - USA map. 2005. Disponível em $<$ http://www.nuclear.com/index-Spent_fuel.html>. Acesso em 25 mar. 2007

TANAKA, T. An international perspective on the management of spent fuel. In: INTERNATIONAL CONFERENCE ON MANAGEMENT OF SPENT FUEL FROM POWER REACTORS, Jun. 19-22, 2006, Vienna. Proceedings... International Atomic Energy Agency, Vienna (Austria); 2007. p. 31 - 40 (IAEA-PUB-1295). 
TAKÁTS, F.; BUDAY, G. Spent fuel storage in Hungary. In: INTERNATIONAL CONFERENCE ON STORAGE OF SPENT FUEL FROM POWER REACTORS, Jun. 2 to 6, 2003, Vienna. Proceedings... International Atomic Energy Agency, Vienna (Austria); Oct 2003. p. 25-29 (IAEA-CN-102/23)

THOMPSON, G. Robust Storage of Spent Nuclear Fuel: A Neglected Issue of Homeland Security. Institute for Resource and Security Studies. Massachusetts, USA. 2003

TRANSNUCLEAR. Products \& Services. 2007. Disponível em <http://www.transnuclear.com/ productsnservices.htm>. Acesso em 20 jul. 2009.

UNB - Universidade de Brasília. Glossário Geológico Ilustrado. Disponível em <http://www.unb.br/ig/glossario/index.html>. Acesso em: 11 jun. 2009.

USNRC - UNITED STATES NUCLEAR REGULATORY COMMISSION. Regulatory

Guide 3.54 - Spent Fuel Heat Generation in an Independent Spent Fuel Storage Installation. Rev 1. Jan 1999

USNRC - UNITED STATES NUCLEAR REGULATORY COMMISSION. A Pilot Probabilistic Risk Assessment of a Dry Cask Storage System at a Nuclear Power Plant. NUREG 1864.WASHINGTON, DC, USA, 2007

USNRC - UNITED STATES NUCLEAR REGULATORY COMMISSION. Disponível em <http://www.nrc.gov/waste/spent-fuel-storage/pools.html> (2007a). Acesso em 25 nov. 2008

USNRC - UNITED STATES NUCLEAR REGULATORY COMMISSION. Disponível em <http://www.nrc.gov/reading-rm/basic-ref/glossary.html> (2007b). Acesso em 28 mai. 2009

USNRC - UNITED STATES NUCLEAR REGULATORY COMMISSION. Code of Federal Regulations, 10 CFR Part 71 Packaging and transportation of radioactive material. Rev. May 2009

USNRC - UNITED STATES NUCLEAR REGULATORY COMMISSION. Code of Federal Regulations, 10 CFR Part 72 Licensing requirements for the independent storage of spent nuclear fuel, high level radioactive waste and reactor-related greater then class $C$ waste. Rev. May 2009a

VERDIER, A.; ROLAND, V.; LEBRUN, M. Interim Storage and Transport casks in Switzerland - COGEMA logistics experience. In: INTERNATIONAL CONFERENCE ON STORAGE OF SPENT FUEL FROM POWER REACTORS, Jun. 2 to 6, 2003, Vienna. Proceedings...International Atomic Energy Agency, Vienna (Austria); Oct 2003. p. 261-269 (IAEA-CN-102/15) 
VOSSNACKE, A.; HOFFMANN, V.; NÖRING, R.; SOWA, W. Management of spent fuel from power and research rectors using CASTOR and CONSTOR casks and licensing experience in Germany. In: INTERNATIONAL CONFERENCE ON STORAGE OF SPENT FUEL FROM POWER REACTORS, Jun. 2 to 6, 2003, Vienna. Proceedings... International Atomic Energy Agency, Vienna (Austria); Oct 2003. p. 142 -149 (IAEA-CN-102/20)

WELLS, A. Spent nuclear fuel shipping basket. National Assurance Corp. Georgia, USA. U.S. Patent 4.930.650, 1990.

WNA - WORLD NUCLEAR ASSOCIATION. World Nuclear Power Reactors 2009-09 and Uranium Requirements., 2009. Disponível em <http://www.worldnuclear.org/info/reactors.html>. Acesso em 8 jul. 2009.

WORLD HEALTH ORGANIZATION (WHO). Depleted uranium. Fact sheet $\mathrm{n}^{0} 257$, 2003. Disponível em <http://www.who.int/mediacentre/factsheets/fs257/en/>. Acesso em 19 jan. 2009.

YANKEE ROWE. Yankee Rowe Used Nuclear Fuel and High Level Radioactive Waste Safely Stored and Ready for Transport. Disponível em < http://www.yankeerowe. com/fuel.html>. Acesso em 20 jan. 2009.

\section{ZAPORIZHZHYA NUCLEAR POWER PLANT, Устройство и описание СХОЯТ} (Armazenagem Seca Distante do Reator). Disponível em <http://www.npp.zp.ua/snfs/ description>. Acesso em 25 nov. 2008.

ZWILAG. Zwischelager Würenlingen, Disponível em <http://www.zwilag.ch>. Acesso em 21 set. 2004. 


\section{BIBLIOGRAFIA COMPLEMENTAR}

ANSI/ANS-8.1-1998;R Nuclear Criticality Safety in Operations with Fissionable Materials

Outside Reactors, American Nuclear Society, LaGrange Park, Ill. USA, 2007

ANSI/ANS-8.3-1997: Criticality Accident Alarm System American Nuclear Society,

LaGrange Park, Ill. USA, 2003.

ANSI/ANS-8.7-1998: Guide for Nuclear Criticality Safety in the Storage of Fissile

Materials American Nuclear Society, LaGrange Park, Ill. USA, 2007.

ANSI/ANS-8.10-1983: Criteria for Nuclear Criticality Safety Controls in Operations With

Shielding and Confinement American Nuclear Society, LaGrange Park, Ill. USA, 2005

ANSI/ANS-8.17-2004: Criticality Safety Criteria for the Handling, Storage, and

Transportation of LWR Fuel Outside Reactors American Nuclear Society, LaGrange

Park, Ill. USA, 2004.

ANSI/ANS-57.9-1992: Design Criteria for an Independent Spent Fuel Storage Installation

(Dry Type) American Nuclear Society, LaGrange Park, Ill. USA, 2000.

ANSI/ANS-57.10-1996: Design Criteria for Consolidation of LWR Spent Fuel American

Nuclear Society, LaGrange Park, Ill. USA, 2006

ASTM C1562 - 03e2 Standard Guide for Evaluation of Materials Used in Extended Service

of Interim Spent Nuclear Fuel Dry Storage Systems. 2008

Bell G. I.; Glasstone S., Nuclear Reactor Theory, Van Nostrand Reinhold, New York, NY

Callihan, A. D.; Ozeroff, W. J.; Paxton, H. C.; Schuske, C. L. "Nuclear Safety Guide”, US Atomic Energy Commission report TID-7016 (1957).

Glasstone, S.; Edlund M.C. The Elements of Nuclear Reactor Theory, D. Van Nostrand Co., Inc., Princeton, NJ (1952).

Isbin H. S., Introductory Nuclear Reactor Theory, Reinhold Publishing Corp., New York, NY (1963)

IAEA - INTERNATIONAL ATOMIC ENERGY AGENCY. Predisposal management of high level radioactive waste. Vienna, Austria, 2003 (IAEA Safety Guide WS-G-2.6)

IAEA - INTERNATIONAL ATOMIC ENERGY AGENCY. Regulations for the Safe

Transport of Radioactive Materials, 1985 Edition, International Atomic Energy

Agency, Vienna (1985) Safety Series No. 6.

IAEA - INTERNATIONAL ATOMIC ENERGY AGENCY. Advisory Material for the

Application of the IAEA Transport Regulations, Second Edition, International Atomic 
Energy Agency, Vienna (1982). Safety Series No. 37

Knief, R. A, Nuclear Engineering, Theory and Technology of Commercial Nuclear Power,

2nd Edition, Taylor \& Francis/ Hemisphere, Washington, DC, 1992.

Lewis, E. E., Nuclear Power Reactor Safety. New York: Wiley, 1977. 630 p.

Standard Review Plan for Spent Fuel Dry Storage Facility. NUREG-1567, Washington, DC March 2008.

Standard Review Plan for Spent Fuel Dry Storage Systems at a General Licence Facility. NUREG-1536 rev 1A, Washington, DC March 2009.

Technical Support for a Proposed Decay Heat Guide Using SAS2H/ORIGEN-S

Data, NUREG/CR-5625 (ORNL-6698), Washington, DC September 1994.

Thomas J. T. (editor) “Nuclear Safety Guide, TID-7016, Revision 2,” US Nuclear

Regulatory Commission report NUREG/CR-00951 ORNL/NUREG/CSD-6, 1978.

Wilson, P. D. (editor) “The Nuclear Fuel Cycle-from Ore to Waste”, Oxford Science Publications, UK, 1996.

49 CFR 173.4, Regulations, Packaging and Transportation, Radioactive Materials, Department of Transportation, US, 1991. 